\title{
EROSÃO GENÉTICA E CONSERVAÇÃO DE GERMOPLASMA DE MANDIOCA NA AGRICULTURA AUTÓCTONE EM UBATUBA-SP
}

\author{
JULIANNO BERGOCH MONTEIRO SAMBATTI \\ Engenheiro Agrônomo
}

Orientador: Prof. Dr. AKIHIKO ANDO

\begin{abstract}
Dissertação apresentada à Escola Superior de Agricultura "Luiz de Queiroz", Universidade de São Paulo, para obtenção do título de Mestre em Agronomia, Área de Concentração: Genética e Melhoramento de Plantas.
\end{abstract}

PIRACICABA

Estado de São Paulo - Brasil

Maio de 1998 
Dissertação : Erosão Genética e Conservação de Germoplasma de Mandioca na Agricultura Autóctone em Ubatuba-SP.

Autor: Julianno Bergoch Monteiro Sambatti

\section{ERRATA}

Tabela 9 (p.66);

\begin{tabular}{|l|c|}
\hline & Roça B \\
\hline Roça A & $\left(1-\overline{\mathrm{Se}} \mathrm{e}_{\mathrm{ii}}(\mathrm{AB})\right) /\left[\left(2-\overline{\mathrm{S}} \mathrm{dii}_{\mathrm{ii}} \mathrm{A}-\overline{\mathrm{Sd}}_{\mathrm{ii}} \mathrm{B}\right) / 2\right]$ \\
\hline
\end{tabular}


Dados Internacionais de Catalogação na Publicação (CIP) DIVISÃO DE BIBLIOTECA E DOCUMENTAÇÃO - Campus "Luiz de Queiroz"/USP

Sambatti, Julianno Bergoch Monteiro

Erosão genética e conservação de germoplasma de mandioca na agricultura autóctone em Ubatuba-SP / Julianno Bergoch Monteiro Sambatti. - - Piracicaba, 1998.

165 p. : il.

Dissertação (mestrado) - Escola Superior de Agricultura Luiz de Queiroz, 1998. Bibliografia.

1. Agricultura tradicional 2. Diversidade genética 3. Etnobotânica 4. Genética vegetal 5. Germoplasma vegetal 6. Mandioca 1. Titulo 


\section{DEDICATÓRIA}

Dedico este trabalho à memória do Professor Paulo Sodero Martins. 


\section{AGRADECIMENTOS}

Agradeço ao Prof. Paulo Sodero Martins pela formação científica e humana que me proporcionou, a qual permitiu a conclusão do trabalho apesar de sua ausência.

À minha familia pelo apoio, amor, confiança e compreensão nas minhas ausências.

À familia Perche, minha familia em Piracicaba.

Aos funcionários da ESALQ, principalmente do Departamento de Genética, que com presteza, competência, companheirismo e amizade contribuiram para a conchusão do trabalho.

Aos meus colegas e amigos do Departamento de Genética e em especial do Laboratório de Genética Ecológica pelo apoio nas horas dificeis, pelo entusiasmo com a ciência e pela companhia agradável durante estes anos.

Aos professores do Departamento de Genética por apoiar a continuidade do trabalho do Prof. Paulo Sodero Martins, em especial ao Prof. Akihiko Ando por abdicar de seus interesses particulares em nome de uma amizade.

À Lurdinha e às Anas, pela forma com que sempre nos acolheram em seu lar.

A todos agricultores caiçaras que participaram direta ou indiretamente deste trabalho e que transmitiram um pouco de seu conhecimento e de sua sabedoria com simpatia, amabilidade, seriedade e confiança.

À CAPES e ao CNPq, pelo suporte financeiro necessário à realização do trabalho. 


\section{SUMÁRIO}

Página

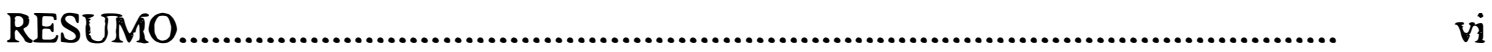

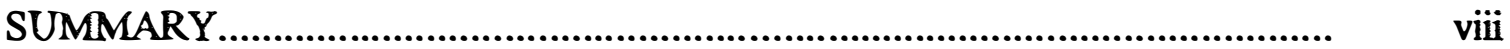

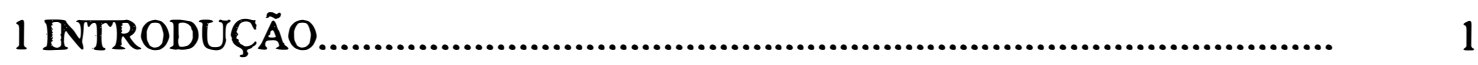

2 REVISÃO DE LITERATURA............................................................ 4

2.1 Plantas cultivadas como recurso genético e erosão genética......................... 4

2.2 Agricultura autóctone e conservação de recursos genéticos in situ................ 6

2.3 Caracterização da agricultura tropical autóctone.................................... 8

2.3.1 Manejo na agricultura tropical autóctone.......................................... 9

2.3.2 Fertilidade do solo e agricultura tropical autóctone.............................

2.4 Agricultura autóctone e diversidade intra e interespecífica........................ 14

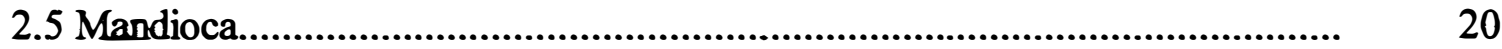

2.6 Isoenzimas, caracteres morfológicos e morfométricos como forma de avaliação da variabilidade genética............................................................ 23

2.7 Índice de Shannon-Weaver como forma de quantificar variabilidade

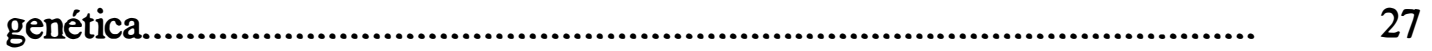

2.8 Seleção, aptidão darwiniana e adaptação................................................ 30

2.9 Domesticação e evolução de plantas cuittivadas........................................ 34

2.10 Diversidade, heterogeneidade ambiental e estabilidade na agricultura......... 38

2.11 Ubatuba...................................................................................... 42

2.11.1 Caiçaras e mandioca no município de Ubatuba...................................... 42

2.11.2 Parque Estadual da Serra do Mar..................................................... 44

3 MATERIAL E MÉTODOS...................................................................... 46

3.1 Descrição da região........................................................................... 46

3.2 Escolha do local, dos agricultores e das roças......................................... 47

3.3 Amostragem de plantas para análise de isoenzimas e amostragem de solos............................................................................................... 49

3.4 Amostragem de plantas para avaliaçāo morfológica e morfométrica........... 50 
3.5 Eletroforese de isoenzimas...................................................................... 56

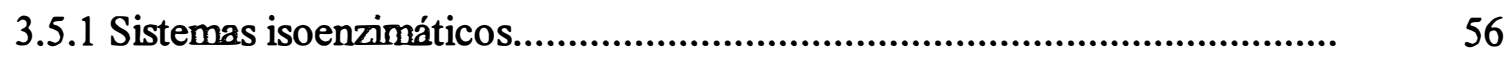

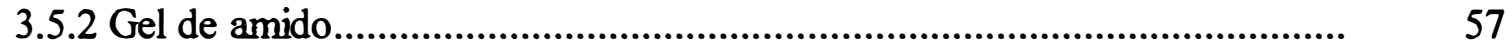

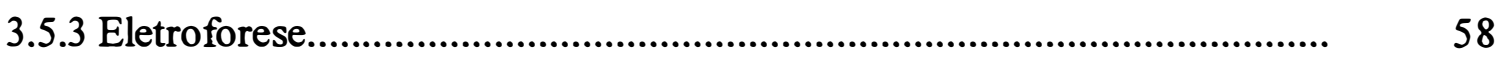

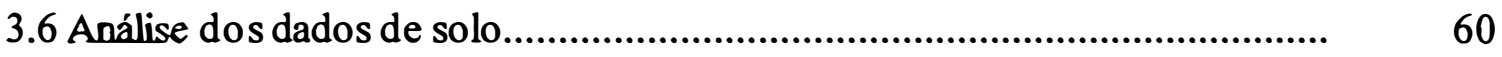

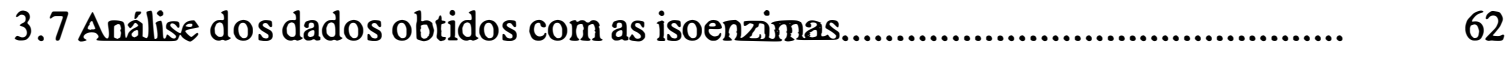

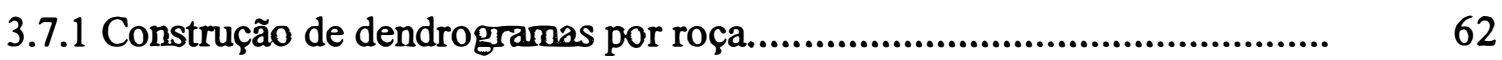

3.7.2 Cálculo do índice de Shannon-Weaver para sistemas isoenzimáticos.......... 64

3.7.3 Construção de dendrograma envolvendo todas as roças.............................. 64

3.8 Cálculo do índice de Shannon-Weaver para variáveis morfológicas

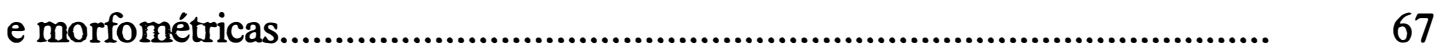

3.9 Análise dos índices de Shannon-Weaver para isoenzimas e

caracteres morfológicos................................................................................

3.10 Entrevista com os agricultores............................................................... 72

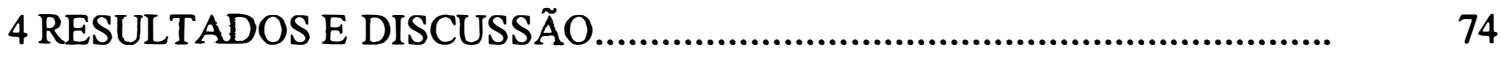

4.1 Roças e fertilidade do solo..........................................................................

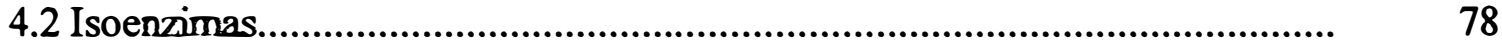

4.3 Comparação da diversidade fenotípica obtida por isoenzimas e a diversidade reconhecida pelo agricultor........................................................ $\quad 80$

4.4 Distância genética entre as roças.................................................................... 91

4.5 Diversidade fenotípica nas roças e a relação com fertilidade do solo............. 93

4.6 Distribuição da diversidade............................................................................ 101

4.7 Seleção, manejo e redução de diversidade..................................................... 104

4.8 Seleção natural e artificial na agricultura tropical autóctone........................... 108

4.9 Manutenção da diversidade.......................................................................... 113

4.10 Erosão genética e política ambiental............................................................. 117

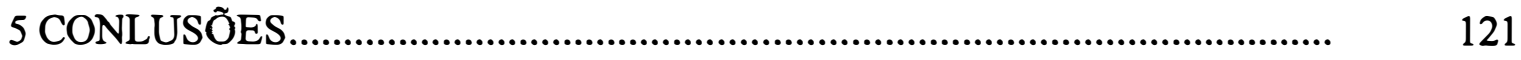

REFERÊNCIAS BIBLIOGRÁFICAS...................................................... 124

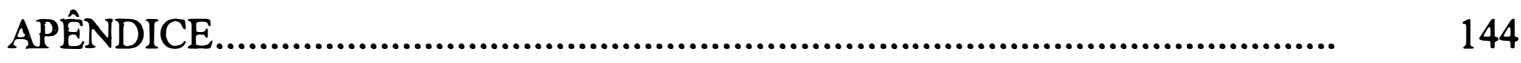




\title{
EROSÃO GENÉTICA E CONSERVAÇÃO DE GERMOPLASMA DE MANDIOCA NA AGRICULTURA AUTÓCTONE EM UBATUBA-SP.
}

\author{
Autor: JULIANNO BERGOCH MONTEIRO SAMBATTI \\ Orientador: Prof. Dr. AKIHIKO ANDO
}

\section{RESUMO}

Na agricultura autóctone a evolução de plantas cultivadas é urn processo contínuo que gera, mantém e amplifica a diversidade genética. A relação entre o seu manejo e este processo evolutivo é ainda pouco conhecida.

A mandioca (Manihot esculenta Crantz) é uma espécie amplamente cultivada por agricultores autóctones das regiões tropicais do Brasil e das Américas, os quais utilizam a agricultura itinerante como manejo típico. No município de Ubatuba (Estado de São Paulo), foram identificados agricultores cultivando mandioca segundo o manejo tradicional e outros cujo manejo foi alterado devido a restrições à abertura de novas áreas para plantio impostas pela legislação ambiental, causando uma redução do período de pousio nas áreas de cultivo.

Objetivou-se neste trabalho comparar a diversidade genética de roças de mandioca destes dois grupos para entender o efeito do manejo na diversidade genética, além de identificar atitudes dos agricultores que tivessem conseqüências evolutivas na população de mandioca.

Foram amostradas plantas de mandioca em cinco roças pertencentes a quatro agricultores diferentes, sendo dois considerados agricultores praticando manejo tradicional e dois considerados agricultores com manejo alterado. Avaliaram-se caracteres isoenzimáticos obtidos pela eletroforese em gel de amido e utilizando os sistemas LAP, SKDH, PGI e MDH. Como cada planta coletada foi identificada pelo agricultor segundo sua classificação própria, comparou-se a diversidade que o agricultor reconhece com a diversidade isoenzimática através de dendrogramas baseados no índice 
de similaridade "simple matching" e no método de agrupamento UPGMA. Observou-se uma coerência da classificação local, sendo que na maioria dos casos esta classificação subestimou a diversidade obtida com as isoenzimas.

Avaliaram-se 22 caracteres morfológicos nas roças e a diversidade para cada caráter isoenzimático e morfológico foi expressa pelo índice de Shannon-Weaver. Amostrou-se solo em cada roça para comparar a fertilidade das roças alteradas e tradicionais. Uma análise de componentes principais (PCA) foi realizada para identificar dentre os componentes da análise de solo quais estariam contribuindo para separar roças tradicionais das alteradas. Teores de potássio $(\mathrm{K})$, fỏsforo $(\mathrm{P})$ e matéria orgânica $(\% \mathrm{MO})$ melhor discriminaram os dois grupos. Realizaram-se novos PCAs para verificar uma possível associação entre fertilidade do solo expressa pelos teores de $\mathrm{K}, \mathrm{P}, \% \mathrm{MO}$ e diversidade genética das roças expressa pelos índices de diversidade de Shannon-Weaver.

Tanto diversidade quanto fertilidade do solo mostraram uma tendência de crescer na direção das roças tradicionais, evidenciando além de uma associação entre fertilidade e diversidade, a existência de uma pressão de seleção direcional atuando nas roças alteradas tal que um genótipo mais adaptado à nova condição de solo passou a predominar nas roças alteradas menos férteis. Isto foi confirmado comparando a diversidade reconhecida na época do trabalho com a diversidade que os agricultores das roças alteradas tem na memória, além de uma descrição precisa de como e porquê a seleção ocorreu. Relatos dos agricultores permitiram concluir que produção, planejamento da colheita, interações entre genótipo e ambientes previsíveis e imprevisíveis, e o desejo de possuir uma reserva de diversidade são fatores que contribuem para manter diversidade na agricultura autóctone de Ubatuba.

Erosão genética ocorre na espécie Manihot esculenta Crantz no município de Ubatuba como conseqüência da redução no período de pousio causada pelas restrições às atividades agrícolas impostas pela legislação ambiental. 


\title{
GENETIC EROSION AND CASSAVA GERMPLASM CONSERVATION IN THE TRADITIONAL AGRICULTURE IN UBATUBA-SP
}

\author{
Author: JULIANNO BERGOCH MONTEIRO SAMBATTI \\ Adviser: Prof. Dr. AKIHIKO ANDO
}

\section{SUMMARY}

In raditional agriculture, crop evolution is a continuous process which generates, maintains and amplifies genetic diversity. The relationship between crop management and this evolutionary process remains poorly understood.

Cassava (Manihot esculenta Crantz) is a species widely cultivated by traditional farmers in tropical regions of Brazil and America, where swidden cultivation is the typical crop management system. In Ubatuba (São Paulo State, Brazil), two groups of raditional farmers cultivating cassava were identified, one with traditional management system and another whose management system was altered owing to restrictions on the opening of new gardens imposed by environmental laws, which led to a reduction in the gardens fallow period.

This work aimed to compare genetic diversity in cassava gardens from these groups in order to understand the effect of management in cassava diversity, and to identify fanners attitudes with evolutionary consequences on cassava population.

Cassava plants from five gardens owned by four frmers were sampled, being two considered traditional farmers and two using altered system. Isozyme traits obtained with starch gel eletrophoresis using LAP, SKDH, PGI and MDH systems were evaluated. Since each collected plant was identified by the farmer following his classification system, the diversity recognized by the farmer was compared with isozyme diversity using cluster analysis with simple matching similarity coeficient and UPGMA clustering method. The farmers' classification system was consistent with isozyme phenotypes, and in most cases underestimated isozyme diversity. 
Twenty two morphological traits were evaluated in the gardens and diversity for each isozyme and morphological trait was expressed by the Shannon-Weaver diversity index. Soil was also sampled in order to compare soil fertility between altered and traditional gardens. Principal component analysis was done in order to identify between soil analysis components that would best discriminate between traditional and altered gardens. Phosphorus $(\mathrm{P})$, potassium $(\mathrm{K})$ and organic matter (\%MO) contents discriminated best the two groups. Other PCAs were applied in order to verify a possible association between soil fertility expressed by $\mathrm{K}, \mathrm{P}$ and \%MO contents and genetic diversity of cassava gardens expressed by the Shannon-Weaver diversity index.

Indeed, not only diversity but also soil fertility tended to increase in traditional gardens, evidencing an association between fertility and diversity and the existence of a directional selective pressure such that the most adapted genotype to the new soil conditions dominated in the altered gardens. This was confirmed by the comparison of the recognizod diversity at the time of the present work with that in the memory of the farmers of altered gardens. Moreover, they provided a precise description of how and why selection took place. Farmers reports led to the conclusion that production, harvest planning, interactions between genotype and predictable and unpredictable environments, and the wish to retain a diversity reserve are factors that contribute to the maintainance of diversity in traditional agriculture of Ubatuba.

Genetic erosion takes place in Manihot esculenta Crantz in Ubatuba and is basically a consequence of fallow period reduction caused by cultivation restrictions imposed by the environmental legislation. 


\section{INTRODUÇÃO}

Desde 1970, quando foi dado o alarme em relação à erosão genética (Frankel, 1970), muito se tem discutido a respeito das estratégias de conservação de recursos genéticos. Como ficou patente no "Earth Summit" do Brasil, em 1992 (Cleveland et al., 1994), um grande destaque tem sido dado à conservação de recursos genéticos in situ, sendo que o papel da agricultura autóctone ou indígena teve sua importância devidamente reconhecida por pesquisadores e instituições que trabalham com a questão, pois variedades locais ou etnovariedades ("landraces") são consideradas uma fonte importante de recursos genéticos (Cleveland et al., 1994).

A associação de conservação de recursos genéticos in situ com formas de agricultura tradicional ou autóctone tem-se mostrado muito promissora, porém um melhor conhecimento de como se dá a relação entre manejo do sistema agrícola, diversidade, dinâmica evolutiva das etnovariedades e suas interações com aspectos culturais, econômicos e ecológicos das comunidades tradicionais é fundamental para viabilizar tal esquema de conservação. De fato, no âmbito internacional, muitos trabalhos vêm sendo conduzidos com o objetivo de entender melhor como este tipo de agricultura pode contribuir para a conservação de recursos genéticos.

No Laboratório de Genética Ecológica do Departamento de Genética da Escola Superior de Agricultura "Luiz de Queiroz", foi estabelecida, já há alguns anos, uma linha de pesquisa voltada ao estudo da manutenção e amplificação da variabilidade genética de mandioca (Manihot esculenta Crantz) como resultado do manejo típico do sistema de agricultura tropical autóctone, o qual, embora tenha uma origem indígena, não se restringiu apenas aos índios, ainda sendo praticado no Estado de São Paulo, 
principalmente no litoral, por comunidades de caiçaras e de negros descendentes de antigos quilombos (Cury, 1993).

Em Ubatuba (Estado de São Paulo) verificou-se a presença de populações autóctones (caiçaras) praticando a agricultura tradicional nos moldes daquela observada em outras regiões do litoral do Estado. Entretanto, à semelhança do que acontece em outras regiões do País consideradas de um modo ou de outro como ambientalmente protegidas e nas quais existem comunidades autóctones, estão em vigor restrições legais a qualquer tipo de agricultura, afetando a liberdade com que indivíduos destas comunidades praticam agricultura e conduzindo a alterações do manejo tradicional.

No caso de Ubatuba, a fiscalização tem coibido a prática agricola, permitindo, em certos casos, que ela possa ser realizada em áreas restritas e sem a possibilidade da utilização do ciclo corte - queima - plantio - pousio, o qual parece ser recorrente em toda a região tropical do globo (Eden, 1988; Eden, 1993; Cury, 1993), caracterizando uma profunda alteração do sistema tropical tradicional autóctone de agricultura. Por outro lado, existem ainda alguns agricultores que praticam agricultura segundo um manejo tradicional. Há, portanto, nesse município, roças (termo mais apropriado para o cultivo autóctone na região) com diferentes graus de alteração do modelo tradicional.

Dentro deste contexto, vislumbrou-se a possibilidade de se fazer um trabalho que relacionasse o papel do manejo da agricultura tropical autóctone na manutenção e amplificação da diversidade genética da mandioca (Manihot esculenta Crantz), aproveitando a possibilidade de comparar roças cujo manejo é tradicional e roças cujo manejo é alterado sob vários aspectos e utilizando várias abordagens. 
Propôs-se, então, a realização de um trabalho de pesquisa que contemplasse os seguintes objetivos:

- Verificar se há alteração da diversidade genética intra-específica em roças de mandioca quando o modelo de agricultura tropical autóctone é alterado.

- Identificar e caracterizar as pressões de seleção relevantes que podem estar associadas a eventuais alterações desta diversidade genética.

- Compreender qual a relação que os agricultores de Ubatuba tem com diversidade na cultura da mandioca e identificar quais fatores estariam influenciando esta relação.

- Havendo a constatação de uma associação entre diversidade genética e manejo, verificar se fatores que estejam influenciando o manejo em Ubatuba podem estar conduzindo à erosão genética na espécie Manihot esculenta Crantz. 


\section{REVISÃO DE LITERATURA}

\subsection{Plantas cultivadas como recurso genético e erosão genética}

Recursos genéticos incluem plantas, animais e microrganismos que podem possuir material genético de valor econômico (Cohen et al., 1991). Pode-se considerar, portanto, os recursos genéticos como sendo expressão da biodiversidade, a qual se refere a todas as espécies de plantas, animais e microrganismos existentes que interagem dentro de um ecossistema (Altieri, 1992).

A invenção e o desenvolvimento da agricultura criou uma grande diversidade genética nas espécies selecionadas para domesticação (Brush et al., 1981). De fato, o conhecimento humano sobre certos aspectos da seleção é pré-histórico e inclui o esforço para a modificação de plantas e animais dos quais o Homem é dependente (Salick, 1995). Portanto, plantas cultivadas são uma forma na qual a diversidade pode ser expressa no sistema agrícola, sendo que ela ocorre em diferentes níveis, podendo estar presente dentro de plantas individuais (heterozigosidade), entre indivíduos dentro de uma variedade heterogênea, entre variedades dentro de uma espécie ou em um grande número de espécies e variedades (Soleri \& Cleveland, 1993).

Plantas cultivadas, principalmente as etnovariedades ${ }^{1}$, são, então, uma forma de recurso genético que é utilizado atualmente por melhoristas primariamente para

\footnotetext{
${ }^{1}$ Os tcrmos "Landracc", "Folk varicty", "Traditional varicty" ou "Primitivc" varicty têm sido definidos como populações ecológica ou geograficamente distintas que são conspicuamente diversas na sua composição genética tanto entre como dentro das mesmas, tendo sido produto de seleção local por agricultores-melhoristas (Cleveland et al., 1994). No entanto, para uma maior uniformização terminológica será utilizado o termo etnovariedade, o qual vem sendo usado no Brasil para designar esse conceito.
} 
transferência de caracteres qualitativos, como resistência a insetos e doenças, às linhagens ou populações melhoradas já existentes (Soleri \& Smith, 1995; Cuevas-Perez et al., 1992). Cuevas-Perez et al., (1992) afirmam que em termos de melhoramento genético vegetal, a exploração de uma base genética reduzida e a predominância de um pequeno conjunto de etnovariedades no processo de melhoramento genético parece ser a abordagem geral para diversas culturas. Como exemplo, pode-se citar o cultivar de arroz IR 8, um dos principais pilares desta espécie na revolução verde, que tem sua constituição genética baseada apenas nas etnovariedades Cina, Lati Sail e Dee Geo Woo Gen (Cuevas-Perez et al., 1992).

Já há alguns anos, foi anunciada uma paulatina redução global da diversidade biológica devido à intervenção humana, comumente conhecida como erosão genética (Frankel, 1970). Em termos de plantas cultivadas, o que se tem de evidência desta erosão genética é baseado em analogia entre o que aconteceu nos EUA e no norte da Europa, onde as etnovariedades foram rapidamente substituídas por cultivares melhorados, e regiões de domesticação de plantas cultivadas nas quais as condições ambientais, culturais e econômicas diferem de várias maneiras das primeiras (Brush, 1995). Entretanto, pouca idéia se tem da extensão das perdas de recursos genéticos (Brush, 1995). O advento da agricultura moderna e o uso de suas variedades criou um novo habitat que, apesar de possivelmente ser mais produtivo segundo alguns parâmetros, foi extremamente empobrecido biologicamente à medida que as etnovariedades foram sendo substituídas pelos cultivares modernos, caracterizando o processo de erosão genética (Brush, 1992; Brush et al., 1981; Cleveland et al., 1994).

Várias são as causas do processo de erosão genética. De acordo com Cohen et al. (1991), esta pode decorrer da: (1) abertura de áreas possuidoras de grande diversidade natural e plantadas com variedades exóticas, (2) substituição de etnovariedades por cultivares exóticos e (3) alteração de práticas agrícolas que resultem em perdas da diversidade tradicionalmente mantida no interior e no entorno de áreas agrícolas manejadas. Hawkes (1983) afirma que a erosão genética ocorre em parte como resultado do sucesso dos melhoristas em produzir melhores variedades, as quais têm ocupado o 
lugar de populações antigas, de formas primitivas e de etnovariedades em locais de grande diversidade. Estas novas variedades altamente melhoradas têm sido adotadas pelos agricultores graças aos seus maiores rendimentos e resistência a doenças e, portanto, as antigas etnovariedades de grande diversidade vão sendo gradualmente excluídas do cultivo. Perdas de etnovariedades também são atribuídas por Cleveland et al. (1994) à redução na dimensão da área de plantio ou à limitação das oportunidades que os agricultores têm de seleção, manejo e troca de etnovariedades. Contudo, há evidências de que os agricultores tradicionais mantém etnovariedades mesmo quando cultivam variedades comerciais melhoradas (Brush, 1991; Brush, 1995).

É clara a dependência da agricultura moderna dos recursos genéticos. $\mathrm{O}$ fato da agricultura moderna consumir esses recursos para criação de cultivares modernos, sem a contrapartida eficiente em termos de conservação dos mesmos criou um problema de sustentabilidade do sistema e coloca essa forma de agricultura numa séria situação de risco.

\subsection{Agricultura autóctone e conservação de recursos genéticos in situ}

A conservação in situ de plantas cultivadas é definida como a conservação de etnovariedades nos agroecossistemas em que foram desenvolvidas e nos quais são correntemente cultivadas (Frankel, 1970).

A primeira idéia que surgiu em relação à conservação de recursos genéticos quando se percebeu a ocorrência da erosão genética partiu da premissa de que esta ocorria em sistemas agrícolas tradicionais e que a substituição de etnovariedades por cultivares modernos era inevitável (Hawkes, 1983). Esta premissa conduziu à conclusão de que todo o esforço conservacionista deveria ser alocado na conservação de recursos genéticos ex situ, em bancos de germoplasma. Assim, virtualmente todos os recursos públicos para a conservação de recursos genéticos ainda têm sido aplicados na conservação ex situ (Brush, 1995; Cohen et al. 1991). 
Contudo, a inevitabilidade da substituição total de etnovariedades por variedades modernas tem sido muito questionada dada uma série de evidências de ordem social, econômica, político-econômica, cultural, institucional e ecológica (Brush, 1992; Brush et al. 1981; Brush , 1995; Bellon \& Brush, 1994; Cleveland et al., 1994). Vários são os argumentos a favor da conservação in situ de recursos genéticos, principalmente com relação às suas vantagens sobre a conservação ex situ.

A conservação de recursos genéticos in situ tem sido considerada uma opção de preservação a longo prazo e de melhoramento natural de certas espécies de plantas cultivadas por diversas razões. A propagação e manejo de certas espécies podem ser muito dificeis no caso de conservação ex situ. O melhoramento genético através de seleção natural e evolução não ocorre em bancos de germoplasma (Cohen et al., 1991). Além disso, é possivel a ocorrência de erosão genética em bancos de germoplasma quando este, por algum motivo, não é manejado adequadamente (Castillo, 1995).

O principal beneficio biológico da conservação in situ sobre a ex situ é a manutenção da evolução de variedades de cultivos sob seleção humana e ambiental, evitando perdas de alelos valiosos devido a estratégias inadequadas de amostragem, ao tamanho de amostra quando em coleta ou ainda a novas pressões de seleção durante a regeneração de acessos ex situ (Soleri \& Cleveland, 1993). Para Brush (1995), a conservação in situ não deve ser encarada só como uma provedora de genes para o melhoramento, mas também um processo que possibilita a preservação de processos evolutivos que geram novo germoplasma sob condições de seleção natural e que é um fornecedor contínuo de material genético para coleções ex situ. Desse modo, a associação entre agricultura autóctone e o material geneticamente diverso tem, segundo Brush et al. (1981), três conseqüências: (1) a manutenção de numerosos genótipos no espaço e no tempo, (2) uma larga distribuição de genótipos específicos e (3) a geração de novos genótipos.

A importância da conservação de recursos genéticos in situ em centros de grande diversidade, como forma de possibilitar a amplificação da variabilidade, principalmente através de fluxo gênico entre variedades dentro de uma mesma espécie e entre a espécie 
cultivada e seus parentes selvagens, tem sido muito destacada por vários autores (Brush et al., 1981; Benz et al., 1990; Zimmerer \& Douches, 1991; Altieri \& Anderson, 1992; Salick, 1992; Brush et al., 1995; Brush, 1995; Castillo, 1995).

A percepção de que a conservação in situ de plantas cultivadas só é possível quando se considera a relação cultural que existe entre a evolução destas plantas e quem as cultiva (povos indígenas, agricultores tradicionais, caboclos, caiçaras etc.) é recorrente na literatura. Para Soleri \& Cleveland (1993), os beneficios potenciais desta forma de conservação só podem ser percebidos se esta estratégia fizer sentido aos agricultores que dela participam. Cury (1993) concluiu que a conservação in situ de germoplasma de mandioca deve manter não só etnovariedades, mas também conservar o ambiente de cultivo original e as práticas agrícolas autóctones, preservando a cultura destas populações no seu sentido mais amplo.

Conservação in situ de recursos genéticos é uma ótima alternativa de conservação, porém é também um desafio, pois deve integrar vários aspectos da questão. Não há, em absoluto, uma dicotomia entre conservação in situ e ex situ, pois são situações que se complementam para uma maior eficiência e segurança da conservação de recursos genéticos como um todo, além de uma maior integração com o melhoramento genético, biotecnologia e outras áreas que desfrutam destes mesmos recursos. Porém antes de propor estratégias de conservação in situ, o papel dos agricultores autóctones na manutenção de diversidade genética deve ser bem compreendido (Altieri \&Anderson, 1992).

\subsection{Caracterização da agricultura tropical autóctone}

Agricultura tradicional ou agricultura autóctone são termos genéricos muito encontrados na literatura utilizados para designar uma gama de sistemas agrícolas nos quais agricultores ainda mantém técnicas transmitidas culturalmente, cuja origem remonta aos primórdios da invenção da agricultura, sendo estas técnicas adaptadas aos ecossistemas das regiões em que são praticadas. Normalmente, a agricultura autóctone 
foge dos padrões preconizados pela agricultura moderna, principalmente pela baixa utilização de insumos e pela utilização de material genético próprio, além de particularidades de manejo e cultivo. Embora muitos destes agroecossistemas sejam pequenas propriedades geograficamente descontínuas e localizados em uma diversidade de altitudes, microclimas e tipos de solo, a agricultura autóctone tem sido cada vez mais confinada a áreas marginais como conseqüência da necessidade de disponibilização de áreas para a agricultura moderna (Altieri \& Anderson, 1992; Brush, 1995).

A agricultura tropical autóctone, é caracterizada basicamente pelo ciclo corte queima e abandono, também conhecida como agricultura itinerante ou agricultura de coivara e será descrita mais profundamente a seguir.

\subsubsection{Manejo na agricultura tropical autóctone}

Cultivo e manejo podem ser diferenciados pelo fato do primeiro estar relacionado a espécies ou populações de plantas, enquanto o segundo com a comunidade de plantas, sistema ou paisagem (Salick, 1995).

A agricultura tropical autóctone é caracterizada por derrubada da vegetação, queima, preparo mínimo do solo e pousio, não sendo este modelo exclusivo do Brasil, pois é praticado por povos de todas as regiões tropicais do globo, como foi mencionado por Alcorn (1990) e Eden (1993). Pode-se encontrar relatos da prática desta agricultura na Nova Guiné Ocidental (Plarre, 1995), Ilhas Carolinas Orientais (Raynor et al.,1992), Papua Nova Guiné (Eden, 1988), Nigéria (Aweto, 1988), além das américas central e do sul (Alcorn, 1990; Boster, 1983; Lessa, 1996; Kerr \& Posey, 1984).

Cury (1993) caracterizou o manejo da agricultura tradicional de modo mais abrangente, baseando numa sintese do que existe na literatura, a qual é sumarizada a seguir:

- É realizada nos mais diversos ecossistemas, como restingas, cerrado, mata de várzea etc. e não apenas em áreas de cobertura florestal.

- O corte da vegetação ocorre no início da estação seca e a queima no final da mesma. 
- A derrubada da vegetação não é aleatória, mas executada de modo que haja concentração de matéria orgânica em alguns setores da roça (designação popular para a área aberta e cultivada).

- O processo de queima é controlado.

- São utilizados desde machados e enxadas a machados de pedra e "paus pontudos", dependendo da comunidade.

- A regeneração da mata após o abandono é muitas vezes realizada de forma manejada.

- Há um manejo tanto da diversidade intra-específica quanto da interespecífica.

- Pode-se ainda acrescentar que a sua alta eficiência em termos energéticos (Uhl \& Murphy, 1981) pode ser apontada como um fator muito importante para justificar sua ampla adoção.

- O cultivo das roças é realizado de 1 a 4 anos (Kang \& Moormann, 1977; Uhl \& Murphy, 1981; Eden, 1988; Aweto, 1988) e o tempo de pousio varia de 3 a 10 anos (Aweto, 1988). Segundo Posey (1987), referindo-se à agricultura praticada pelos Caiapó, embora o auge da produção se mantenha durante 2 a 3 anos, suas roças continuam fornecendo produtos até 4 a 5 anos após o plantio.

Alcorn (1990) caracteriza o modelo de agricultura tradicional conduzido no México pelos Huastec e os Bora peruanos de modo muito semelhante ao descrito acima e acrescenta que a estratégia indígena de retirada da floresta é baseada num sistema agroflorestal seqüencial que integra a vegetação sucessional secundária no sistema de manejo, mantendo a regeneração florestal como parte do sistema.

Para Geertz citado por Vickers (1983), a agricultura itinerante é conscientemente planejada de modo a simular a estrutura ambiental protetora de uma floresta tropical madura, selecionando cultígenos para preencher certos nichos que formam uma estrutura similar a uma comunidade biótica. No entanto, na interpretação de Vickers (1983), a agricultura autóctone é conduzida para maximizar a produção de culturas de importância, aproveitando os espaços intersticiais entre plantas da mesma espécie e aproveitando também o fato de que essas culturas diferem em suas taxas de crescimento. Outro fato 
importante que vai contrário à teoria de Geertz é a constatação de que há uma grande variação na diversidade interespecífica entre áreas cultivadas mesmo em locais bem próximos, o que implica na existência de outros fatores que influenciam o manejo nestas áreas (Hames, 1983; Vickers, 1983; Eden, 1988; Eden, 1993; Alcom, 1990).

A recorrência da agricultura tropical autóctone parece indicar que a adaptação do processo de sucessão secundária à agricultura é uma solução para vários dos problemas inerentes ao cultivo nos trópicos e por isso é encontrada em várias regiões tropicais do mundo.

\subsubsection{Fertilidade do solo e agricultura tropical autóctone}

Uma das principais alterações ambientais que a agricultura tropical autóctone provoca está relacionada com a fertilidade do solo. A derrubada da cobertura vegetal, sua queima e posterior cultivo contribuem sobremaneira para uma certa dinâmica em relação à fertilidade do solo. Alguns autores tem estudado esta dinâmica, principalmente após a derrubada, queima e cultivo.

Aweto (1988), comparando solos tropicais na Nigéria com cobertura florestal e solos após cultivo por agricultores praticando agricultura tropical autóctone, pode observar uma menor fertilidade geral dos solos após cultivo, expressa principalmente pelos teores de matéria orgânica, potássio, fósforo, cálcio e magnésio além da menor porosidade e maior teor de areia dos solos cultivados, principalmente nas camadas superiores do solo. Entretanto, a diferença dos teores de cálcio não foi significativa. A matéria orgânica é a principal responsável pelo aumento da capacidade de troca catiônica em solos tropicais. Sua redução causa redução da capacidade do solo em adsorver nutrientes cuja conseqüência é o aumento das taxas de lixiviação. Ainda segundo Aweto (1988), a extensão da redução da fertilidade do solo é controlada por diversos fatores

incluindo quais culturas foram cultivadas, por quanto tempo, sob qual intensidade, quais condições climáticas e a fertilidade intrínseca do solo. 
Um trabalho experimental realizado por Mazzarino et al. (1988), simulando uma condição típica das regiões tropicais de queima da cobertura vegetal para estabelecimento de agricultura, conclui que uma sucessão de monoculturas não afeta a fertilidade do solo caso suas condições originais sejam de alta saturação de bases. Por outro lado, uma queda contínua da saturação de bases ocorre caso as condições iniciais sejam de baixa saturação de bases, o que caracteriza uma forma de retroalimentação negativa. A manutenção do solo sem cobertura vegetal conduz a uma redução da saturação de bases com conseqüente aumento da acidez, perda de bases, diminuição da atividade microbiana e aumento significativo da fixação de fósforo.

Kang \& Moormann (1977), estudando na Nigéria o cultivo de milho segundo a técnica de agricultura itinerante em blocos originários respectivamente de uma floresta secundária a qual havia sido cultivada com inhame nove anos antes, de uma vegetação em estágio sucessional inicial com árvores de cerca de 6 metros, a qual havia sido cultivada com mandioca quatro anos antes, e de uma área recentemente cultivada com mandioca, observaram que uma maior colheita foi obtida no bloco da floresta secundária seguido do bloco de vegetação em tamanho intermediário e da roça de mandioca. A média do conteúdo de carbono também variou na mesma seqüência. $O$ teor de fósforo, apesar de baixo, foi significativamente maior no bloco da floresta secundária que os outros dois blocos, assim como o teor de potássio trocável. Segundo os autores, os resultados claramente demonstram o perigo de reduzir o período de pousio na agricultura itinerante sem a adição de nutrientes.

Entretanto, trabalhos que abordam seqüencialmente o manejo tem permitido observar que logo após a derrubada e queima as condições do solo melhoram significativamente.

Uhl \& Murphy (1981) mostram que, em cultivos autóctones de mandioca no sul da Venezuela, as condições do solo são favoráveis ao crescimento durante o primeiro ano devido à liberação de cátions pelas cinzas, tendo o pH variado de 3,9 (antes da queima) para 5,5 (logo após a queima), o que favorece a disponibilidade de nutrientes e a redução da toxidez por alumínio. No entanto, o pH retornou ao valor inicial após 22 meses. 
Erosão, colheita e lixiviação foram consideradas causas de perdas de nutrientes. Uma maior erosão foi observada após o primeiro ano, pois durante o primeiro ano o solo ainda apresenta restos de raizes que o protegem. Kumada et al. (1985), num trabalho experimental envolvendo derrubada da vegetação, queima e cultivo de mandioca com e sem preparo do solo na ilha de Okinawa (Japão), também puderam observar um aumento do $\mathrm{pH}$ mesmo no periodo entre a derrubada e a queima, o que foi atribuido à adição de bases provenientes da vegetação derrubada. Foi observado também que o conteúdo de nitrogênio, nitrogênio mineralizável e carbono diminuíram com o cultivo da mandioca e esta redução foi mais rápida onde foi feito preparo de solo, o que indica um possivel motivo pelo qual não se faz preparo de solo em agricultura tropical autóctone.

Lessa et al. (1996), num trabalho realizado no nordeste do Brasil, estimaram que a adição de cinzas pela queima da vegetação é da ordem de 11 toneladas por hectare. As cinzas são fonte importante de cálcio e magnésio, muito acima do que é necessário à cultura da mandioca. Já nitrogênio e potássio são fornecidos pelas cinzas, porém em quantidade insuficiente para a mesma cultura. O conteúdo de fósforo fornecido pelas cinzas se aproximou da necessidade da cultura da mandioca. A mineralização de raízes após a queima contribui com quantidade considerável de nitrogênio. Potássio parece ter sido o elemento limitante para o cultivo da mandioca no local. $\mathrm{O}$ aumento do $\mathrm{pH}$ após a queima parece favorecer a atividade microbiana. Perdas de nutrientes do solo foram atribuídas basicamente à lixiviação e absorção pela cultura, entretanto os autores ressaltam o papel das plantas invasoras na reciclagem dos nutrientes que estariam sendo lixiviados.

Baseando-se na literatura citada, a dinâmica da fertilidade do solo pode ser sumarizada da seguinte forma:

- Após a derrubada da vegetação inicia-se a transferência de bases da vegetação para o solo causando elevação do $\mathrm{pH}$, e aumento da saturação de bases. 
- A queima da vegetação acrescenta ainda mais bases ao solo, favorecendo a atividade microbiana, disponibilizando nutrientes e favorecendo o crescimento das plantas cultivadas.

- Com o início do cultivo a matéria orgânica começa a ser mineralizada liberando principalmente nitrogênio para o solo.

- O solo começa a perder nutrientes por lixiviação erosão e, finalmente, pela extração da cultura. Paralelamente, a paulatina queda do teor de matéria orgânica do solo diminui sua proteção contra erosão e aumenta sua compactação. Uma queda geral da fertilidade do solo pode ser observada.

- $\mathrm{O}$ pH retorna ao seu nível original.

- O abandono do cultivo propicia o crescimento de uma comunidade de plantas invasoras que deve reciclar os nutrientes restabelecendo após alguns anos as condições de um solo com cobertura florestal.

- Espécie cultivada, intensidade de cultivo, tempo de cultivo, tempo de pousio e manejo do solo são fatores determinantes desta dinâmica.

\subsection{Agricultura autóctone e diversidade intra e interespecífica}

A diversidade biológica tem pelo menos duas abordagens básicas: aquela concernente ao nível interespecífico, relacionada ao número de espécies que coexistem num ecossistema, e aquela relacionada ao nível intra-especifico, referente à variabilidade genética dentro de uma mesma espécie.

Muitos trabalhos têm abordado a associação entre agricultura autóctone e diversidade biológica através do número de espécies que são cultivadas neste sistema. Kerr \& Posey (1984) descrevem a agricultura caiapó no nível interespecífico. Plarre (1995) verificou que os Mek da Nova Guiné cultivam misturas de diferentes clones e diferentes espécies, não tendo sido observado monocultivos em sua agricultura. Embora Eden (1988) tenha encontrado na Papua Nova Guiné tanto cultivos altamente diversos quanto mais homogêneos, sugerindo que a associação entre agricultura autóctone e 
diversidade interespecífica não é uma regra absoluta, Salick (1995) afirma que diversidade é a marca do manejo tradicional e indígena de comunidades de plantas. Para alguns autores, no manejo de recursos naturais na agricultura tropical autóctone, há uma integração entre plantas domesticadas, semi-domesticadas e selvagens (Martins, 1994; Altieri \& Anderson, 1992; Posey, 1987) e, nas terras baixas da América do Sul, a adoção da agricultura foi feita sem o abandono da prática da coleta (Martins, 1994).

Para abordar a diversidade intra-específica associada à agricultura autóctone, muitos trabalhos utilizam a classificação local, taxonomia local ou taxonomia "folk" (Quiros et al. 1990) para obter informações a respeito desta diversidade. O problema deste método é o fato de assumir que esta taxonomia reflete fidedignamente a diversidade genética real. Nessa linha, Kerr \& Posey (1984) utilizaram a taxonomia "folk" para fazer inferências sobre a diversidade intra-específica de culturas como mandioca, batata-doce, cará, banana entre outras. Boster (1984) usou método semelhante para discutir seleção de mandioca pelos índios Aguaruna na Amazônia. Salick et al. (1997) utilizaram a taxonomia local aliada à avaliação de caracteres morfológicos para o estudo da manutenção, geração, uso e perda de diversidade genética de mandioca entre os índios Amuesha na Amazônia peruana.

Quando a variabilidade genética é quantificada objetivamente e comparada com aquela reconhecida pelos agricultores através de sua taxonomia, tem-se observado que esta taxonomia subestima a real variabilidade genética, como mostra Quiros et al. (1990) em batatas andinas avaliadas por marcadores bioquímicos, apesar da grande acurácia deste sistema taxonômico. Faraldo (1995) fez uma constatação semelhante em etnovariedades de mandioca do litoral sul do Estado de São Paulo. Peroni ${ }^{2}$ também confirma esta tendência entre os agricultores da região de Ariri no litoral sul de São Paulo.

\footnotetext{
${ }^{2}$ Pcroni, N. Taxonomia folk c diversidade intra-cspecifica de mandioca (Manihot esculenta Crantz) $\mathrm{cm}$ roças de agricultura tradicional em áreas de Mata Atlântica do sul do Estado de São Paulo. Piracicaba (no prelo). 191p. Dissertação (Mestrado)-Escola Superior de Agricultura "Luiz de Queiroz", Universidade de São Paulo.
} 
Que diversidade intra e interespecífica é uma característica marcante da agricultura autóctone praticada em todo o mundo é reconhecido pela grande maioria dos autores, entretanto os motivos e os mecanismos que levam os agricultores a manter esta diversidade ainda são ponto de discussão.

Aspectos humanos (culturais, econômicos, sociais etc.) e ecológicos e a interação entre estes dois fatores são freqüentemente apontados como determinantes na manutenção de diversidade genética em plantas cultivadas (Altieri \& Anderson, 1992; Brush, 1995; Boster, 1994).

Abordando a questão com ênfase no ponto de vista humano, Harlan, citado por Brush et al. (1981), afirma que etnovariedades são produto de seleção humana para características como cor, sabor, textura e qualidade no armazenamento. Brush et al. (1981) apontam heterogeneidade varietal como um dos mais importantes atributos dos campos agrícolas dos agricultores andinos no Peru. No mesmo trabalho, os autores afirmam que os agricultores mantém seus cultivares nativos, apesar da presença de cultivares melhorados, basicamente pelo sabor, qualidade no armazenamento e viabilidade do propágulo. Sabor, padrões culinários, interesses pessoais, prestigio, fatores agronômicos, oportunidades econômicas e status social também contribuem para a decisão de se manter a diversidade (Brush, 1992). Rousi et al. (1989) atribuem a presença de diferentes clones de Ulluco (Ullucus tuberosus) em campos agricolas do sul do Peru em parte à troca destes clones entre vilas e regiões. Salick (1997) destaca experimentação, sabor, beleza, comércio, transporte de outras regiões e uma contínua reciclagem de variedades como explicação do alto grau de variabilidade de mandioca existente entre os índios Amueshas.

Já do ponto de vista ecológico, heterogeneidade ambiental é tida como um motivo crucial pelo qual se mantém diversidade, pois com uma maior diversidade pode-se ter uma produção relativamente estável em diferentes ambientes, aumentando a segurança alimentar dos agricultores (Ceccarelli, 1996; Salick et al., 1997; Brush et al., 1981; Bellon, 1996; Altieri \& Anderson, 1992; Harlan, 1975). Neste contexto, a deficiência em termos de produção de um genótipo em determinado ambiente tem a chance de ser 
compensada pela maior produção de um outro genótipo. Esta questão será discutida com uma maior profundidade adiante.

Do ponto de vista econômico, foi estabelecido teoricamente que pelo cultivo simultâneo de culturas ou variedades com diferentes variâncias e/ou covariâncias dos retornos, os agricultores podem minimizar os riscos enquanto maximizam o retorno médio (Just \& Zilberman, citados por Bellon, 1996), ou minimizam a probabilidade de estar abaixo de um nível mínimo de subsistência (Roumasset, citado por Bellon, 1996).

Altieri \& Anderson (1992) sumarizaram os fatores ecológicos e humanos que, associados, contribuem para a geração, manutenção e amplificação da diversidade genética de plantas cultivadas por agricultores autóctones da América Latina nos seguintes ítens:

- Cultivo de raças primitivas por métodos tradicionais.

- Sistemas agrícolas relativamente pequenos.

- Diversidade ambiental dentro de roças.

- Adaptação local a estresses ambientais e biológicos.

- Seleção e manutenção consciente de sementes pelos agricultores.

- Fragmentação geográfica que cria mecanismos de isolamento os quais conduzem a uma rápida diferenciação.

- Redes de troca de sementes entre agricultores dentro e entre vilas e grupos culturais.

- Diversidade étnica, a qual tem como conseqüência sistemas de classificação, usos e manejos distintos para etnovariedades distintas.

- Tolerância de plantas invasoras aparentadas dentro e no entorno das roças, aumentando as possibilidades de hibridação interespecífica.

- Interações ecológicas entre a vegetação das roças e dos ecossistemas selvagens do entorno. 
A resposta de porquê agricultores autóctones individuais mantém diversidade intraespecífica não é simples ou única. Uma tentativa de responder esta pergunta de modo mais sistematizado foi feita por Bellon (1996). Sua interpretação é baseada nas seguintes premissas:

- Agricultores possuem um conjunto de interesses ("concerns") associados a determinado cultivo e tem conhecimento de como cada variedade se comporta em relação a cada interesse e relativo a cada uma das outras variedades que cultiva.

- Estes interesses mudam devido à incorporação dos agricultores no mercado, ao acesso a novas tecnologias, oportunidades de trabalho e ao impacto de políticas governamentais.

Na Tabela 1 extraída de Bellon (1996) são relacionados exemplos do que seriam estes interesses, como a diversidade pode satisfazer estes interesses e como pode-se substituir a diversidade como forma de satisfaze-los.

No modelo de Bellon (1996), o conjunto de interesses deve ser considerado um espaço multidimensional e pode ser expresso através de um vetor matricial no qual cada elemento é um interesse. Cada cultivar que o agricultor possui pode ser expresso como um vetor cujos elementos são escores relativos aos elementos do vetor de interesses. $\mathrm{O}$ conjunto de variedades pode ser expresso como uma matriz contendo os vetores de escores de cada variedade. Ainda segundo o modelo, o agricultor avalia cada variedade com respeito a cada interesse, estabelece um "ranking" destas variedades e tenta adequar a melhor variedade a cada interesse. O problema é que nenhuma variedade sozinha satisfaz todos os interesses do agricultor (Bellon \& Brush, 1994), pois algumas tem maior escore para um determinado interesse mas perdem em outro interesse. A solução é utilizar mais de uma variedade para satisfazer todos os interesses. Variedades são descartadas quando todos seus escores são superados por outras variedades. Em contrapartida, variedades são incluídas se pelo menos parte de seus escores superam as outras variedades existentes. 
Tabela 1-Conjunto de interesses que um agricultor tradicional pode possuir, possibilidade de ser satisfeito pela diversidade intra-especifica e possibilidades desta diversidade ser substituida na satisfação destes interesses. (Extraido de Bellon, 1996).

\begin{tabular}{|c|c|c|}
\hline Interesses & $\begin{array}{l}\text { Bens e serviços fornecidos pela } \\
\text { diversidade intra-especifica }\end{array}$ & $\begin{array}{c}\text { Substitutos da diversidade intra- } \\
\text { especifica }\end{array}$ \\
\hline $\begin{array}{l}\text { Heterogeneidade ambiental (solos, } \\
\text { temperatura, chuvas, fotoperíodos } \\
\text { etc.) }\end{array}$ & $\begin{array}{l}\text { Habilidade de cultivar em } \\
\text { diferentes ambientes }\end{array}$ & Irrigação, fertilizantes etc. \\
\hline Pestes e patógenos & $\begin{array}{c}\text { Habilidade de reduzir perdas por } \\
\text { pestes e patógenos }\end{array}$ & Pesticidas \\
\hline Riscos no manejo & $\begin{array}{l}\text { Habilidade de reduzir riscos na } \\
\text { produção (seca, geada etc.) }\end{array}$ & $\begin{array}{c}\text { Seguros comerciais ou } \\
\text { governamentais, trabalho não } \\
\text { ligado à agricultura }\end{array}$ \\
\hline Cultura e rituais & $\begin{array}{l}\text { Habilidade de preencher os rituais, } \\
\text { fornecer prestigio, forjar laços } \\
\text { sociais. }\end{array}$ & $\begin{array}{c}\text { Compra de itens relacionados a } \\
\text { prestígio e rituais, trabalho } \\
\text { assalariado }\end{array}$ \\
\hline Dieta & Dieta variada & Produtos comerciais \\
\hline
\end{tabular}

Bellon (1996) divide os agricultores segundo suas condições ecológicas, tecnológicas e sócio-econômicas. Assim, eles poderiam ser classificados basicamente como (1) agricultores de subsistência, (2) agricultores de subsistência que comercializam excedentes e (3) agricultores comerciais. Segundo o modelo descrito acima, pode-se esperar encontrar uma maior diversidade genética numa determinada cultura entre os agricultores de subsistência que comercializam excedentes, pois estes tem de atender um maior número de interesses do que as outras duas possibilidades.

As implicações do manejo que se realiza no sistema de agricultura autóctone na diversidade ou variabilidade genética intra-especifica foram parcamente abordadas nos trabalhos mais antigos. Observa-se, porém, um crescente aumento de publicações a esse respeito dado o maior interesse na conservação de recursos genéticos in situ. Trabalhos 
pioneiros com esta abordagem são os de Kerr \& Clement (1980) e Kerr \& Posey (1984), os quais tratam, entre outros assuntos, da relação existente entre o manejo agricola e suas conseqüências evolutivas sobre a variabilidade intra-especifica da mandioca entre os indios Kayapó.

\subsection{Mandioca}

A mandioca, Manihot esculenta Crantz, pertence a classe Dicotiledoneae, subclasse Archichlamydeae, ordem Euphorbiales, tribo Manihoteae e gênero Manihot. Esta espécie é uma das principais plantas úteis tropicais difundidas em todos os continentes (Dominguez et al., 1984; Schmidt, 1958). Dentro do gênero Manihot foram classificadas cerca de uma centena de espécies, sendo a espécie Manihot esculenta a única cultivada comercialmente, com 2n=36 (Graner, 1941). O gênero apresenta espécies com duas características econômicas importantes: a presença de raízes tuberosas com acúmulo de amido, cujo expoente é $M$. esculenta e a extração de látex, cujo expoente é $M$. glaziovii (Gulick et al., 1983)

Aspectos taxonômicos e morfológicos da espécie podem ser encontrados em Rogers \& Appan (1973) e Dominguez et al. (1984).

A mandioca é uma espécie domesticada pelos ameríndios, cujo centro de origem ainda provoca alguma controvérsia (Dominguez et al., 1984; Cury, 1993; Nye, 1991 e Martins, 1994). A maioria dos botânicos considera a mandioca uma planta originária da América tropical e aponta o nordeste do Brasil como o mais provável centro de origem (Hawkes, 1991; Viegas, 1976). Porém, Amazônia (Schmidt, 1951), México (Rogers, 1972) e Venezuela (Sauer, 1952) também são cogitadas como possíveis centros de origem. Martins ${ }^{3}$ considerou que a domesticação da mandioca não deve ter ocorrido num determinado ponto, mas em vários locais diferentes simultaneamente. Aparentemente, após sua domesticação, a mandioca foi dispersa para outras regiões pelos indígenas que

\footnotetext{
${ }^{3}$ Martins, P.S. (Departamento de Genćtica da Escola Supcrior de Agricultura "Luiz de Quciroz"). Comunicação pessoal, 1996.
} 
praticavam agricultura (Viegas, 1976). A maior diversidade se encontra no Brasil, México e Guatemala (Dominguez et al., 1984).

O processo de domesticação da mandioca é pouco conhecido. Rogers \& Appan (1973) reconhecem a espécie Manihot esculenta Crantz apenas na forma domesticada. Jennings (1979) especula que a domesticação da mandioca envolveu seleção para tamanho da raiz tuberosa, hábito de crescimento ereto, menor número de ramificações e habilidade de propagação vegetativa através de pedaços do caule, as manivas. De fato, a mandioca é propagada pelo Homem exclusivamente via propagação vegetativa (Martins, 1994), apesar de não ter perdido seu sistema reprodutivo sexual como mostram Graner (1942b) e Iglesias et al. (1994b), e fazem referência Jennings (1979), Boster (1984), Martins (1994) e Salick(1997).

Kerr \& Clement (1980) e Martins (1994) destacam as vantagens de, no processo de domesticação da mandioca assim como de outras plantas cultivadas tropicais, ter-se conseguido manter a reprodução vegetativa associada com a sexual. Com isso, genótipos favoráveis, mesmo aqueles resultantes de mutação, podem ser fixados via reprodução vegetativa e novos genótipos podem ser criados via reprodução sexual.

Uma das características mais utilizadas na classificação popular de etnovariedades de mandioca é seu sabor doce ou amargo muitas vezes correlacionado à toxicidade decorrente da presença de $\mathrm{HCN}$ em diferentes concentrações. Etnovariedades consideradas amargas não são apreciadas para o consumo in natura e são exatamente estas comumente consideradas tóxicas e utilizadas para o fabrico de produtos derivados da mandioca como farinha, tapioca, polvilho etc. De fato, processos de secagem, compressão, fritura, cozimento etc. são reconhecidos como forma de detoxificação (Lancaster et al., 1982). Considera-se que as vantagens de ter-se selecionado variedades com alto teor de $\mathrm{HCN}$ se relacionam à defesa das mesmas contra insetos e principalmente contra mamíferos (Nye, 1991). A repetibilidade da correlação positiva entre sabor amargo e toxicidade por HCN tem sido questionada por alguns autores (Nye, 1991). 
Devido ao seu comportamento genético, alta heterozigosidade e forte depressão quando submetida à endogamia, pode-se considerar a mandioca como preferencialmente exogâmica (Gulick et al, 1983; Martins, 1994). Outra evidência de exogamia é o fato da mandioca ser uma espécie monóica cujas flores femininas se abrem cerca de dez dias antes das flores masculinas do mesmo ramo, caracterizando a protoginia e, portanto, favorecendo o cruzamento (Martins, 1994).

Dados na literatura são escassos a respeito do isolamento reprodutivo do cultígeno, os que existem apontam no sentido de que as espécies selvagens do gênero Manihot compartilham de um conjunto gênico comum, porém em diferentes graus (Cury, 1993). De fato, há vários relatos de cruzamentos viáveis entre Manihot esculenta e parentes selvagens (Gulick et al., 1983; Nassar, 1989; Lefèvre \& Charrier, 1993a; Lefèvre \& Charrier, 1993b).

As espécies do gênero Manihot são heliófilas e muitas são invasoras capazes de colonizar áreas abertas. Raramente estas espécies se tornam dominantes na vegetação (Gulick et al., 1983; Jennings, 1979; Cury, 1993).

A mandioca é uma espécie notável quanto a sua capacidade de crescimento vigoroso em solos pobres, a sua resistência a pragas e doenças (Martins, 1994) e sua adaptação a diferentes regiões edafoclimáticas, ocorrendo desde regiões de floresta tropical a regiões de cerrado e caatinga (Gulick et al., 1983; Cury, 1993; Lessa et al., 1996).

Do ponto de vista da nutrição mineral da mandioca, variabilidade genética foi observada quanto aos niveis de absorção de fósforo e exportação de potássio e enxofre (Lorenzi et al., 1980). Diferenças na adaptação a solos com baixos níveis de fósforo foram basicamente relacionadas a diferenças nos padrões de repartição da matéria seca entre raizes e parte aérea e a diferenças na eficiência do uso de fósforo (Pellet et al., 1993a). A deficiência de fósforo deve limitar mais o crescimento da parte aérea do que das raizes (Pellet et al., 1993b). Pode-se esperar que, se a mandioca é cultivada continuamente sem fertilização, o potássio seja o elemento mais limitante ao seu desenvolvimento como conseqüência da alta extração deste elemento nas colheitas 
(Howeler, 1991; Lorenzi et al., 1980). Uma alta correlação entre a presença de endomicorrizas vesículo-arbusculares e absorção de fósforo foi constatada por Atayese et al.(1993) e Ezeta \& Carvalho (1982), sugerindo que esta associação é essencial em solos com baixos teores de fósforo para o desenvolvimento da cultura. Já o potássio não apresentou uma correlação significativa com endomicorrizas (Ezeta \& Carvalho, 1982)

Em termos agronômicos, uma grande vantagem apresentada pela mandioca é o fato de que suas raízes podem ser conservadas vivas no solo, o que torna o período de colheita altamente flexível, permitindo que esta possa ocorrer durante todo 0 ano (Martins, 1994). No entanto, Purseglove citado por Nye (1991) reconhece variabilidade genética neste caráter, havendo variedades que podem ser colhidas com 6 meses e que não podem ser conservadas por mais de 9 a 11 meses, enquanto outras, mais tardias, podem ser conservadas no solo até 4 anos.

A combinação das suas características agronômicas, sistema de reprodução, variabilidade genética, da existência de muitas espécies selvagens aparentadas, da sua grande difusão não só restrita ao continente americano e do fato de que é a principal espécie cultivada na agricultura autóctone no Brasil e em várias regiões tropicais da América, faz da mandioca uma espécie ideal para o estudo das implicações evolutivas decorrentes da prática da agricultura autóctone na estrutura genética de plantas cultivadas, mais especificamente da manutenção, geração e amplificação da variabilidade genética dentro desta espécie, o que tem sérias implicações na conservação de recursos genéticos in situ.

\subsection{Isoenzimas, caracteres morfológicos e morfométricos como forma de avaliação da variabilidade genética}

Um grande impacto em genética de populações deve-se ao desenvolvimento da técnica de deteç̧ão eletroforética entre proteínas solúveis. O material protéico de um indivíduo é colocado de um lado de uma fatia de gel, o qual migra ao longo do gel após 
ser submetido a uma corrente elétrica, formando bandas que podem ser coradas e analisadas (Weir, 1996). O padrão destas bandas é herdável e pode ser interpretado como um fenótipo repetível que mostra diferenças discretas e não ambíguas entre genótipos (Lewontin, 1974). Embora apenas 30\% das proteínas sejam solúveis e apenas $25 \%$ das diferenças nas seqüências de DNA para genes estruturais permitirem que diferenças de carga sejam detectadas pela eletroforese, a técnica ainda é a mais fácil e a mais barata maneira de se obter dados de muitos individuos e diversos locos (Weir, 1996).

Muitos trabalhos ainda têm sido realizados utilizando-se a técnica de isoenzimas como forma de avaliação da variabilidade em plantas cultivadas. Uma abrangente descrição da técnica de eletroforese de isoenzimas pode ser encontrada em Alfenas et al. (1991).

Lefèvre \& Charrier (1993a) utilizaram a técnica de eletroforese de isoenzimas para avaliação do grau de introgressão do germoplasma de Manihot esculenta africano com M. glaziovii fora do centro de diversificação utilizando os sistemas GOT-B, SDH-A, MDH-A, IDH-A, PGD-B, EST-A, PGI-A e AMP-A polimórficos, além de examinar a herança de 17 sistemas isoenzimáticos em duas espécies de Manihot (Lefèvre \& Charrier, 1993b). A mesma técnica foi utilizada por Brondani (1996) com os sistemas SKD, LAP, HK, SOD, ACP, ALP, PGD, PGI, ALD, IDH, MDH, PGM, AK, GOT, NADHDH, GDH e NADPHDH com o objetivo de estimar similaridade genética entre as espécies $M$. flabelifolia, M. peruviana e M. pilosa. Faraldo (1995) avaliou a variabilidade genética das mesmas variedades estudadas por Cury (1993), as quais foram coletadas em roças do Litoral Sul do Estado de São Paulo próximo a Cananéia e ao Vale do Ribeira, utilizando os sistemas SKDH, LAP, MDH, $\alpha$ - EST e AAT. Peroni ${ }^{4}$ utilizou as enzimas GDH, CAT, AAT (GOT), MDH, $\alpha$-EST, EM, PGM, MADH, LAP, SKDH, e PGI para avaliar a acurácia da taxonomia local de mandioca de agricultores do litoral sul de São Paulo.

\footnotetext{
${ }^{4}$ Pcroni, N. Taxonomia folk c divcrsidade intra-cspecifica de mandioca (Manihot esculenta Crantz) $\mathrm{cm}$ roças de agricultura tradicional em áreas de Mata Atlântica do sul do Estado de São Paulo. Piracicaba (no prelo). 191p. Dissertação (Mestrado)-Escola Superior de Agricultura "Luiz de Queiroz", Universidade de São Paulo
} 
Brush et al. (1995) utilizaram os sistemas enzimáticos PGI-1, MDH-1, GOT-1 e GOT-2 para avaliar parâmetros populacionais como heterozigosidade, identidade genética e distância genética de raças locais de batata no seu centro de domesticação andino. Quiros et al. (1990) utilizaram isoenzimas para verificar a acurácia da taxonomia "folk" para batatas cultivadas andinas.

Eletroforese em gel de amido nos sistemas MDH-1, MDH-2, IDH-1, 6-PDGH-3, PGI-1, GOT-1, PGM-2, PGM-1 e DIA-1, foi utilizada por Zimmerer \& Douches (1991) para medir a variação isoenzimática entre etnovariedades de batatas andinas, estimando a partir destes dados o número de alelos por locos polimórficos e heterozigosidade total.

Até o desenvolvimento da técnica da eletroforese, a maior parte dos trabalhos de avaliação da variabilidade genética em populações de plantas era realizada com base na variação genética de caracteres morfológicos e quantitativos. Com o desenvolvimento de técnicas de eletroforese de isoenzimas e, mais recentemente, técnicas moleculares que utilizam diretamente o DNA, o uso de caracteres morfológicos passou a ter muitas vezes um papel secundário nessa tarefa. No entanto, é inegável a contribuição que esta metodologia ainda pode dar aos estudos relacionados à quantificação da variabilidade genética, pois além de ser reconhecidamente eficiente, seus custos são relativamente pequenos.

Graner (1942a) estudou a herança de dois caracteres de mandioca, largura das folhas e coloração da película suberosa da raiz, concluindo que ambos apresentam segregação simples, obedecendo a primeira lei de Mendel e são independentes entre si. Folhas com lóbulos alongados (tipo vassourinha) são dominantes sobre lóbulos largos e raízes com película marron são dominantes sobre película branca. Segundo Hershey \& Amaya (1984), a coloração da nervura das folhas, verde ou roxa, é também utilizada como marcador. Em Hershey \& Ocampo (1989), produção de clorofila (normal contra albino), hábito de crescimento (reto contra zig-zag), cor do colênquima do caule (verde claro contra verde escuro), cor do parênquima da raiz (branco contra amarelo) e forma do lóbulo da folha mostraram segregações mendelianas simples sugerindo o uso destes caracteres como marcadores. 
A maioria dos caracteres de importância agronômica da mandioca é controlada por sistemas poligênicos. Acosta-Espinosa (1984) encontrou baixa herdabilidade para os caracteres altura da primeira ramificação, diâmetro da planta, peso da parte aérea, distribuição de raizes e média herdabilidade para altura da planta e índice de colheita. Kawano (1984) indicou que os caracteres índice de colheita, conteúdo de matéria seca na raiz e resistência a bacteriose apresentam alta correlação entre pais e filhos.

Pereira et al. (1992), utilizando o método multivariado de componentes principais (PCA), avaliaram a capacidade discriminatória dos seguintes descritores morfológicos em mandioca: facilidade de colheita, distância entre cicatrizes foliares, cor do caule, hábito de ramificação, altura da primeira ramificação, altura da planta, cor das folhas não expandidas, número de lóbulos foliares, forma do lóbulo central, comprimento do lóbulo central, largura do lóbulo central, cor do pecíolo, número de dias do plantio ao florescimento, textura da superficie da raiz, cor do periderme da raiz, facilidade de remoção do periderme, cor da superficie exterior do córtex da raiz, cor da polpa, comprimento da raiz, presença de pedicelo radicular, presença de constrições na raiz, produção da raiz fresca, porcentagem de amido, indice de colheita, resistência a antracnose, ferrugem e oídio e resistência a ácaros. Alguns descritores puderam ser descartados pelo fato de não serem informativos ou por serem redundantes.

Cury (1993) avaliou o germoplasma de mandioca coletado entre os agricultores do Litoral Sul do Estado de São Paulo através dos caracteres: cor do broto foliar, cor da folha adulta, cor do pecíolo de folhas adultas, cor da base da nervura das folhas, morfologia do lóbulo foliar, sinuosidade do lóbulo foliar, pubescência das folhas jovens, número de lóbulos por folha, comprimento do pecíolo, comprimento da folha, cor do caule jovem, cor do caule adulto sem a película externa, proeminência das cicatrizes foliares, pedúnculo, cintas, cor da película externa da raiz, cor da casca da raiz sem a película externa e cor da polpa da raiz. Os descritores utilizados se basearam nos trabalhos de Leitão Filho (1971) e Silva (1981) com modificações, pois priorizou-se aqueles que podem ser avaliados no estado juvenil de desenvolvimento, descartando-se os descritores sujeitos a uma grande influência ambiental. 
Salick et al. (1997) avaliaram a diversidade em mandioca baseando-se em tamanho de planta, forma, ramificação; coloração e hábito de brotos, cor de ramos maduros, do pecíolo, das nervuras e do caule; cor das sépalas, do disco, do estígma, do ovário e da antera; forma da raiz e comprimento do pedúnculo; posição, comprimento, diâmetro da raiz e número de raízes por planta; textura e cor das raízes; facilidade de tirar a casca; cor da película interna e do tecido interno de armazenamento; comprimento do peciolo e número de lóbulos por folha.

Barros (1991) obteve estimativas de diversidade genética por isoenzimas de genótipos de cajueiro utilizando os sistemas peroxidase (PER) e glutamato oxaloacetato (GOT) e comparou com estimativas de divergência genética baseada em avaliações de trinta caracteres morfométricos, verificando discrepâncias entre os resultados. Discrepâncias como esta aparecem com freqüência na literatura (Price et al., 1984; Millar, 1986; Hamrick, 1989) e reforçam a conveniência de se utilizar uma combinação da técnica de eletroforese de isoenzimas com a avaliação de caracteres morfológicos como forma de se obter uma melhor idéia da variabilidade genética de uma espécie como a mandioca

\section{7 Índice de Shannon-Weaver como forma de quantificar variabilidade genética}

$O$ indice de Shannon-Weaver foi criado inicialmente para quantificar diversidade de espécies em estudos ecológicos. Este índice depende basicamente da riqueza de espécies em uma determinada comunidade e a equitabilidade com que os indivíduos são distribuídos entre as espécies (Begon et al., 1996). Assim, quanto mais alto é o valor do índice, maior é o número de espécies e menor é o domínio da comunidade por uma ou poucas espécies (Odum, 1975).

Este índice tem sido muito utilizado para quantificar diversidade genética, principalmente quando os caracteres são considerados frequências fenotípicas (Puecher et al., 1996). Embora variação isoenzimática seja uma boa indicação de diversidade genética (Ibañez et al., 1993), muitos autores preferem considerar bandas isoenzimáticas como 
marcadores fenotípicos ao invés de marcadores genotípicos, principalmente quando há falta de informações a respeito da genética das bandas e neste caso o índice de ShannonWeaver é largamente utilizado.

O índice de Shannon-Weaver é calculado segundo a seguinte fórmula:

$H^{\prime}=-\sum_{i=1}^{n} p_{i} \log p_{i}$

onde $\mathrm{n}$ é o número de classes fenotípicas para um determinado caráter e $\mathrm{p}_{\mathrm{i}}$ é a proporção do número total de entradas na iésima classe. O logaritmo tem sido utilizado com a base 2, 10 ou e. Muitas vezes o índice de Shannon-Weaver é normalizado pelo valor máximo que o caráter em questão poderia fornecer na população total, que é expresso pelo logarítmo de n. Este índice varia, então, de 0 a 1.

$$
H_{\text {norm }}^{\prime}=H^{\prime} / H^{\prime}{ }_{\max }=-\sum_{i=1}^{n} p_{i} \log p_{i} / \log n
$$

Bechere et al. (1996) utilizaram o índice de Shannon-Weaver para quantificar a diversidade genética de etnovariedades de trigo utilizando caracteres morfológicos e morfométricos, realizando análise de variância hierarquizada com os dados obtidos. Análises de variância hierarquizadas utilizando o índice de Shannon-Weaver também foram utilizadas por Jain et al. (1975) para avaliar os padrões geográficos da distribuição da diversidade expressa por caracteres morfológicos e para determinar a contribuição relativa de vários países aos recursos genéticos de uma coleção de Triticum turgidum L. Trabalho similar envolvendo germoplasma de Setaria italica L. coletado em diversas regiões da China utilizando-se caracteres morfológicos e análise hierarquizada de variância foi realizado por Li et al. (1996). Engels (1994) também utilizou o índice de Shannon-Weaver na avaliação de cevada da Etiópia baseando-se em caracteres morfológicos. $\mathrm{O}$ autor pode estabelecer padrões de distribuição da diversidade genética 
em relação a altitude através de análise de variância hierarquizada por faixas de altitude. Bekele (1983) utilizou o indice de Shannon-Weaver para quantificar a diversidade genética em etnovariedades de cevada provenientes de 19 regiões diferentes através de informações obtidas a partir de isoenzimas. Bekele \& Bekele (1996) avaliaram a diversidade genética de cacau do "International Cocoa Gene Bank of Trinidad" com dados provenientes de caracteres morfológicos através do indice de Shannon-Weaver.

A diversidade obtida pelo indice de Shannon-Weaver pode ser repartida entre diversidade dentro de grupos e diversidade entre grupos como mostram Di Renzo et al. (1991) e Ibañez et al. (1993) com dados obtidos a partir de isoenzimas e Puecher et al. (1996) com dados obtidos a partir de caracteres. Esta partição da diversidade é baseada no cálculo da diversidade dentro de grupos (regiões, acessos, variedades etc.) e da diversidade total do que foi analisado. Obtendo-se a diversidade total e calculando-se a média das diversidades dentro de grupos pode-se calcular a proporção da diversidade total que está entre os grupos e dentro dos grupos pela simples relação:

diversidade dentro $=$ média das diversidades $\left(\mathrm{H}_{\mathrm{o}}{ }^{\prime}\right) /$ diversidade total $\left(\mathrm{H}_{\mathrm{t}}{ }^{\prime}\right) \mathrm{e}$ diversidade entre $=1$ - diversidade dentro.

O índice de Shannon-Weaver apresenta, no entanto, algumas limitações que devem ser levadas em conta. Primeiramente, o indice utilizado para estudos evolutivos não tem um claro significado biológico. Outro ponto negativo do uso deste indice é o fato deste ser muito sensível a pequenas frações como discutem Hennink \& Zeven (1991) e Chakraborty \& Rao (1991). 


\subsection{Seleção, aptidão darwiniana e adaptação}

A estrutura do argumento utilizado por Darwin para fundamentar a teoria da seleção natural tornou-se um poderoso sistema para prever mudanças em todos os níveis de organização biológica e pode ser sumarizada pelos seguintes pontos (Lewontin 1970): 1. Diferentes indivíduos numa população diferem quanto à morfologia, fisiologia e comportamento. (variação fenotípica).

2. Diferentes fenótipos possuem diferentes taxas de reprodução e sobrevivência em diferentes ambientes. (aptidão darwiniana diferencial).

3. Há uma correlação entre parentais e progênie na contribuição de cada para futuras gerações (aptidão darwiniana é herdável).

Estes três princípios juntos incorporam o princípio da evolução através da seleção natural.

Para Dobzhansky (1967), a seleção natural age como um mecanismo de controle cibernético que transmite informações acerca dos desafios impostos pelo ambiente ao conjunto gênico de uma dada população. Genótipos que diferem na aptidão darwiniana são transmitidos de geração para geração em diferentes taxas, ou seja, tem um sucesso reprodutivo diferencial.

Para melhor entender este processo, pode-se considerar o modelo mais simples de crescimento populacional em gerações discretas (Crow \& Kimura, 1970).

$\mathrm{N}_{\mathrm{t}+1}=\mathrm{w}_{\text {med }} \mathrm{N}_{\mathrm{t}}$

onde

$\mathrm{N}_{\mathrm{t}+1}=$ número de indivíduos na geração $\mathrm{t}+1$

$\mathrm{N}_{\mathrm{t}}=$ número de indivíduos na geração $\mathrm{t}$

$\mathrm{w}_{\text {med }}=$ taxa intrínseca de crescimento ou valor adaptativo médio da população (aptidão darwiniana). 
tem-se em $t$ gerações uma população $\mathrm{N}_{\mathrm{t}}$ :

$\mathrm{N}_{\mathrm{t}}=\mathrm{N}_{\mathrm{o}} \mathrm{W}_{\mathrm{med}}^{\mathrm{t}}$

onde $\mathrm{N}_{\mathrm{o}}=$ população na geração zero e t o número de gerações.

A população cresce se $w>1$ e diminui se $w<1$

Se a população $\mathrm{N}$ for composta, por exemplo, de duas classes de indivíduos (talvez diferentes genótipos) com diferentes valores adaptativos (aptidão darwiniana) w, uma classe de indivíduos deve estar deixando mais descendentes que outra e, portanto, aumentando a sua proporção na população (Crow \& Kimura, 1970). N pode ser extendido a indivíduos, genes, clones, populações etc. (Lewontin, 1970)

Seleção natural atua sobre fenótipos (Lande \& Amold, 1983) e causa alterações observáveis no decorrer de uma geração nas médias, variâncias e covariâncias de distribuições fenotípicas (Amold \& Wade, 1984). Seleção pode então ser descrita puramente em termos fenotípicos sem o recurso da herança de caracteres. Em contraste, as respostas evolutivas à seleção, como a alteração de uma média fenotípica de geração para geração, certamente dependem da herdabilidade dos caracteres envolvidos (Amold \& Wade, 1984).

O "combustível" da seleção é a variabilidade em caracteres associados com a aptidão darwiniana. Quando não há variabilidade genética não há seleção. Quando há uma ampla variância na aptidão darwiniana há também uma grande oportunidade para seleção (Amold \& Wade, 1984).

A principal conseqüência da atuação da seleção em populações é maximizar sua aptidão darwiniana média, ou seja, aumentar a freqüência de genótipos mais adaptados ao ambiente em que estão sendo selecionados (Crow \& Kimura, 1970). Fisher (1958), afirma que a taxa de incremento da aptidão darwiniana em qualquer organismo num dado período de tempo é igual à sua variância genética naquele período. Seleção altera variâncias. Se a variância é incrementada ou reduzida depende de fatores como 
frequêencias alélicas, dominância, epistasia, ligação e sistema reprodutivo (Crow \& Kimura, 1970). Adaptação é conseqüência da seleção e pode ser definida como um processo de modificação evolutiva de um dado caráter sob seleção para cumprir sua função mais eficientemente num determinado contexto (West-Eberhard, 1994)

Aptidão darwiniana é, no entanto, um conceito muitas vezes vago e tem sido expressa como taxa de crescimento populacional (Futuyma, 1992), habilidade de transmitir alelos (Hedrick, citado por MacGraw \& Caswell, 1996), a tendência de se deixar maior ou menor progênie (Begon et al., 1996), o produto de fertilidade e sobrevivência (Ehrlich \& Roughgarden, citados por MacGraw \& Caswell, 1996), o número médio de indivíduos por progênie de indivíduos do mesmo genótipo (Kimura, 1958) ou a medida da taxa de incremento de indivíduos que possuem genótipos ou fenótipos conhecidos (MacGraw \& Caswell, 1996). Para Dobzhansky (1967), a aptidão darwiniana de um genótipo é uma medida sempre relativa à aptidão darwiniana de outro genótipo.

Esta aptidão darwiniana pode ser decomposta em componentes da história vital relacionados com sobrevivência e reprodução, como mortalidade diferencial no estado juvenil, mortalidade diferencial no estágio adulto, viabilidade diferencial, sucesso diferencial na reprodução sexual, fertilidade diferencial e fecundidade diferencial (Grant, 1985). Conseqüentemente, a seleção também pode ser decomposta em episódios seletivos os quais multiplicativamente se combinam para determinar a aptidão darwiniana total (Stratton, 1992). Além disso, fatores ambientais podem não afetar a aptidão darwiniana diretamente mas afetar caracteres que afetam indiretamente a aptidão darwiniana (Mauricio \& Mojonnier, 1997).

No caso de plantas cultivadas, a interpretação da aptidão darwiniana é um tanto mais complexa, principalmente pelo fato de comumente ter-se separado seleção artificial de seleção natural. Uma linhagem, um genótipo ou um cultivar será considerado adaptado (possuidor de uma maior aptidão em relação aos outros) a um determinado conjunto de condições (climática, agronômicas, edảficas etc.) quando também é capaz de realizar uma produção econômica e não somente sobreviver em tais condições. 
Reconhece-se, portanto, que pode haver adaptação sem produtividade econômica, mas não há produtividade sem adaptação (Ceccarelli, 1996). Em suma, pelo fato de que no agroecossistema ser o Homem quem determina o sucesso reprodutivo (aptidão darwiniana) das espécies domesticadas (Salick, 1995), um determinado genótipo deve, além de sobreviver, atender aos interesses de quem o está cultivando e desta maneira garantir sua reprodução.

Salick (1995) considera a distinção entre seleção artificial e natural uma classificação artificial decorrente da conviç̧ão passada de que seleção consciente humana é algo que deva ser separado da natureza e questiona se o Homem não seria, em última análise (sob a perspectiva da planta domesticada), apenas um herbívoro e um agente de dispersão ou defesa, exercendo pressões de seleção conscientemente ou não. Além disso, a seleção humana favorece inconscientemente, no processo de domesticação, sistemas reprodutivos que facilitem seleção, a própria domesticação e o cultivo (Salick, 1995).

Para uma dada quantidade de variabilidade, seleção em populações assexuadas, como as constituídas puramente por clones, costuma ser mais eficiente que seleção em populações sexuadas. Para a primeira interessa a variação genotípica enquanto que para a segunda a variação gênica ou alélica. Entretanto, se o ambiente muda de modo que uma drástica alteração no fenótipo é necessária, uma população assexual (na ausência de novos mutantes) é limitada pelo melhor genótipo existente. Já populações sexuadas recombinantes podem produzir fenótipos que superem grandemente aos encontrados na população original. A vantagem de populações recombinantes se dá de duas maneiras. Primeiramente, esta torna possível que mutantes favoráveis em diferentes individuos possam aparecer num único indivíduo. A segunda vantagem se refere ao fato de que em ambientes que estão em constante mudança, a recombinação dá à espécie a possibilidade de se adaptar mais eficientemente às alterações ambientais (Crow \& Kimura, 1970). 


\subsection{Domesticação e evolução de plantas cultivadas}

Plantas cultivadas são o resultado de um processo evolutivo conhecido por domesticação (Harlan 1975). Este processo se baseia (1) na seleção artificial, a qual cria e mantém populações cultivadas das espécies de interesse, (2) na atuação da seleção natural nas próprias populações cultivadas, nas populações de ancestrais selvagens e em populações da mesma espécie que, apesar de espontâneas, acompanham o Homem, as "plantas invasoras" ("weeds") e (3) no fluxo gênico dentro e entre estas três populações (Harlan, 1975).

Harlan (1975) reconhece, como foi mencionado acima, três grupos, ou três populações de plantas da mesma espécie que tem papel crucial no processo de domesticação. O primeiro grupo, as populações selvagens, são populações espontâneas que ocorrem em ambientes naturais não perturbados pelo Homem. O segundo grupo, as plantas invasoras ou "weeds", são populações pertencentes à mesma espécie das populações selvagens, as quais, apesar de espontâneas, estão adaptadas a ambientes alterados pelo Homem. O terceiro grupo, as plantas cultivadas, estão adaptadas ao ambiente de cultivo criado pelo Homem e podem ou não ser espontâneas, pois dependem do Homem para sua sobrevivência e reprodução. Como os três grupos tem tênues barreiras reprodutivas entre sí, há a possibilidade de ocorrência de fluxo gênico entre os mesmos.

No modelo de domesticação de cereais proposto por Harlan (1975), antes da criação da agricultura existiam apenas os dois primeiros grupos. $O$ Homem provavelmente coletava e consumia sementes das plantas invasoras e agia como se fosse um outro animal herbívoro qualquer, pois favorecia a disseminação de genes associados à deiscência das sementes, ou seja, as sementes caídas no chão tinham maior chance de ser recrutadas do que aquelas que ficavam mais tempo presas a planta mãe. A partir do momento que o Homem resolveu plantar parte das sementes que coletava, foi desencadeado um processo de seleção automática favorecendo a indeiscência das sementes, pois só as sementes que ficavam mais tempo presas a planta mãe eram 
plantadas. Complementando o processo, seleção inconsciente para uniformidade de germinação, de periodo de colheita, enfim, caracteres agronômicos, produziu o que hoje chamamos de plantas cultivadas.

Para Salick (1992), o processo de domesticação não é restrito ao passado, pois plantas cultivadas nos seus agroecossistemas evoluem continuamente e novas espécies continuam a ser domesticadas. Populações selvagens e invasoras interagem com populações de plantas cultivadas a tal ponto que espécies como a seringueira (Hevea brasiliensis) pouco diferem de seus parentes selvagens. De fato, Salick (1992), estudando domesticação de Cubiu (Solanum sessiliflorum), fruta comestivel encontrada na extremidade norte dos Andes e na Amazônia ocidental, pode concluir que este processo se baseia basicamente na seleção para eliminação de espinhos e observou altas pressões de seleção contra plantas espinhosas (caráter qualitativo) quando em cultivo e altas pressões de seleção favorecendo plantas espinhosas em populações naturais submetidas a herbivoria por mamiferos, apesar da ocorrência de fluxo gênico entre estas populações. Além deste caráter, diversos tamanhos e formas de frutos também são objeto de seleção pelos agricultores. A continuidade do processo de domesticação foi também relatada por Xolocotzi (1985) em milho, Johannessen (1982) em milho e Johns \& Keen (1986) em batata.

Utilizando a roça de mandioca como unidade evolutiva, pois é nesta unidade que os processos evolutivos básicos ocorrem, Cury (1993) elaborou um modelo de dinâmica evolutiva de mandioca que leva em conta o fato da mandioca, apesar de ser reproduzida clonalmente pelos agricultores, possuir um sistema reprodutivo sexual capaz de gerar novos recombinantes, os quais aparecem na roça pela germinação espontânea de sementes, amplificando a variabilidade genética da população (roça) como resultado de cruzamentos entre diferentes clones, hibridações interespecíficas e autofecundação, sendo este conjunto de novos genótipos, assim como os genótipos já existentes, objeto de seleção natural, seleção perceptiva e seleção consciente pelos agricultores. Deste modo, os agricultores mantém o conjunto original de etnovariedades através da reprodução clonal e obtém novas etnovariedades pelo processo sexual. Este modelo foi revisto e 
ampliado por Martins ${ }^{5}$ e pode ser melhor observado na Figura 1. Modelo muito semelhante foi descrito por Johns \& Keen (1986) em batata andina.

Figura 1-Modelo de dinâmica evolutiva de mandioca proposto por Martins ampliado a partir de Cury (1993).

CULTIGEN

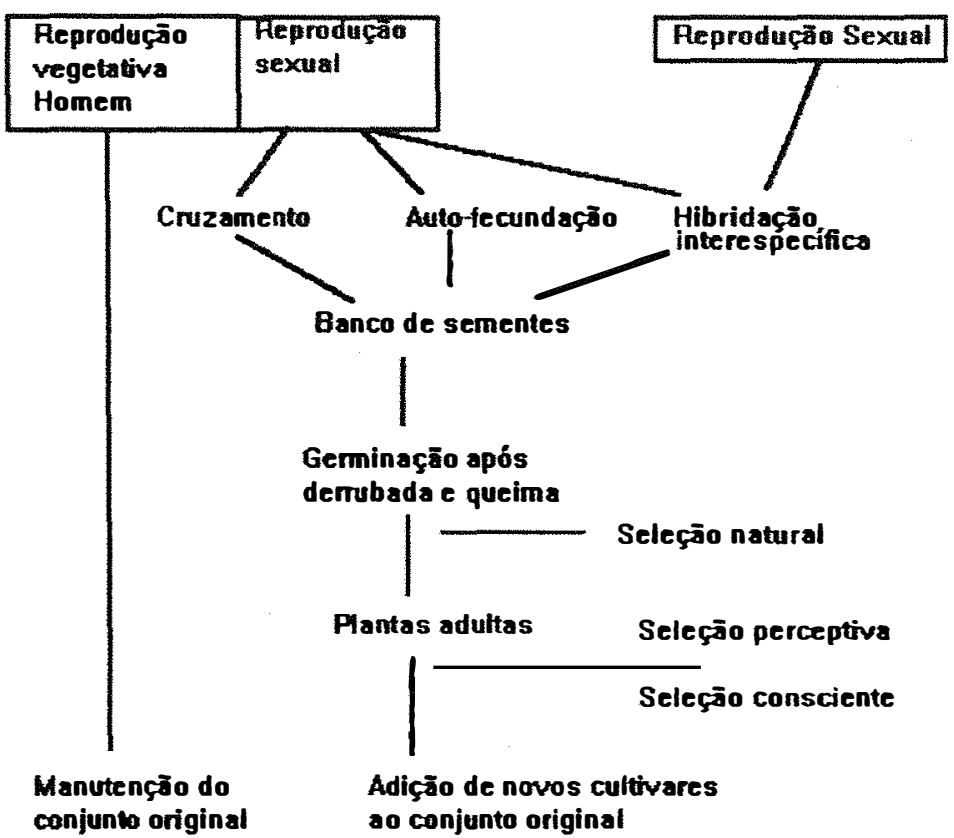

Domesticação é tido como um processo que gerou e gera continuamente muita diversidade genética. Este fato já era notado no século passado e foi fonte de material para Darwin discutir seleção artificial, seleção natural, variação e outros pontos relevante de sua teoria (Fisher, 1958; Harlan, 1975). Entretanto, mais recentemente tem-se notado que a amplificação de variabilidade como consequeência do processo de domesticação pode ser observada para determinada classe de caracteres, principalmente aqueles sujeitos à seleção humana. Gepts \& Debouck (1991) observaram que em feijão, hábito de

${ }_{5}^{5}$ Martins , P.S. (Departamento de Genćtica da Escola Supcrior de Agricultura Luiz de Quciroz). Comunicação Pessoal, 1996. 
crescimento, tamanho e forma de semente são caracteres que nas espécies cultivadas são indubitavelmente mais variáveis que entre as espécies selvagens. Já, a proteína faseolina mostra uma tendência oposta. Os primeiros são caracteres passiveis de seleção humana e o processo de domesticação deve ter conduzido a adaptações específicas a sistemas agrícolas específicos. Faseolina, por outro lado, é um caráter molecular que não pode, até o advento de novas técnicas moleculares, ter sofrido seleção humana. Arroz (Oka, 1975), cevada (Clegg et al., citado por Gepts \& Debouck, 1991) e tomate (Brown, citado por Gepts \& Debouck, 1991) mostraram tendências semelhantes.

Em mandioca, Boster (1984) e Boster (1985) afirma que a seleção realizada pelos indios Aguaruna tende a ser realizada em categorias taxonômicas, as quais são discriminadas basicamente por caracteres morfológicos que podem ser percebidos ainda no campo como cor de pecíolo e caule, cor do broto, cor da folha jovem, forma da folha e arquitetura da planta. Estes caracteres são normalmente neutros, do ponto de vista adaptativo. A partir destes caracteres são feitas inferências a respeito das qualidades agronômicas, culinárias e outras características consideradas importantes, sendo estes caracteres utilizados como uma espécie de marcador, o que é possível pelo fato da planta ser propagada clonalmente. Como estes agricultores normalmente desejam manter e reconhecer certa diversidade, eles ampliaram a variabilidade destes caracteres para que pudessem identificar etnovariedades. Boster (1985) ainda argumenta que, embora haja maior variação para estes caracteres taxonômicos neutros na espécie cultivada em relação às outras espécies de Manihot, caracteres adaptativos apresentam a tendência oposta $\mathrm{e}$ afirma que caracteres relacionados com pigmentação são ideais como caracteres taxonômicos, pois tem pouca importância adaptativa, necessitam pouco investimento em energia para produção de antocianinas e tornam os cultivares prontamente distingüiveis. Pode-se ainda mencionar que este tipo de seleção para aumento de variação de caracteres neutros deve estar mais relacionado com espécies cujo órgão economicamente importante está oculto, como a mandioca. Em plantas como o milho, caracteres mais associados com produção são predominantemente enfocados na seleção realizada pelo agricultor (Johannessen, 1982; Boster, 1985). 


\subsection{Diversidade, heterogeneidade ambiental e estabilidade na agricultura}

Em geral, uma maior diversidade na agricultura está associada com uma maior estabilidade, isto é, menor variação na produção de ano para ano (Soleri \& Cleveland, 1993). Costuma-se fazer também uma associação entre complexidade do ecossistema, a qual é decorrente de sua diversidade, e estabilidade. Esta complexidade permitiria ao ecossistema uma melhor homeostase contra estresses ambientais como alterações climáticas, doenças etc. (Hames, 1983; Brush, 1992).

Do ponto de vista da diversidade interespecífica, entretanto, apesar da validade da associação entre diversidade e estabilidade ser amplamente aceita (Brush, 1992), alguns autores como Kimmerer (1984) criticam essa hipótese devido à falta de demonstrações matemáticas, empíricas ou experimentais que a suportem. Um dos problemas cruciais da hipótese estabilidade-diversidade é a falta de definições adequadas e medidas de diversidade e estabilidade (Hames, 1983).

Por outro lado, do ponto de vista da diversidade intra-específica, calcada numa sólida teoria, a qual conceitua detalhadamente o que é diversidade genética (Hartl \& Clarck, 1989; Weir, 1996; Crow \& Kimura, 1970), é possível colher evidências de que diversidade genética e estabilidade estão correlacionadas. Como exemplo, pode-se citar a longa história de epidemias agrícolas associadas com bases genéticas estreitas (Brush, 1992). Além disso, o conceito de estabilidade quando voltado ao estudo de plantas cultivadas permite uma maior viabilidade de abordagens experimentais, pois é possivel estudar apenas poucos caracteres, especialmente aqueles de importância econômica, permitindo que o restante varie (Allard \& Bradshaw, 1964). Portanto, é crucial para o tratamento do problema responder a pergunta: estabilidade do que se deseja enfocar?

Um outro aspecto que deve ser levado em conta para abordar o problema é a questão do ambiente. Para Allard \& Bradshaw (1964) as variações ambientais podem ser divididas em duas classes: aquelas previsíveis e as imprevisíveis. Na primeira categoria pode-se incluir todas as características permanentes do ambiente como características gerais do clima e tipo de solo, assim como aquelas características do ambiente que 
flutuam de uma maneira sistemática, como comprimento do dia. A segunda categoria inclui flutuações do clima, tais como quantidade e distribuição de chuvas e temperatura. As interações entre genótipo e estas duas categorias de variação ambiental podem ser utilizadas para expressar a estabilidade do caráter em questão. Grandes interações entre genótipo e ambientes previsíveis como locais, regiões, níveis de fertilidade, data de semeadura etc., podem indicar que estes fatores caracterizam ambientes muito especiais para os quais genótipos bem adaptados podem ser desenvolvidos. Por outro lado, a existência de interações entre genótipo e variações ambientais imprevisiveis, como interação genótipo $\mathrm{x}$ ano, torna impossível a criação de um genótipo adaptado a circunstâncias que não se pode prever. Allard e Bradshaw (1964) identificam, então, dois caminhos para superar a imprevisibilidade do ambiente. O primeiro é a existência ou o desenvolvimento de genótipo cuja interação com variações ambientais imprevisíveis seja bem baixa, denominada homeostase individual ("individual buffering"). A segunda, chamada de homeostase populacional ("populational buffering"), se refere à homeostase que ocorre quando há interações entre genótipos diferentes que coexistem num mesmo local.

Um exemplo de homeostase populacional pode ser observado no trabalho de Allard (1961), o qual comparou a estabilidade de três diferentes populações de feijão lima com relação à produção. A primeira composta por três linhas puras, a segunda composta por uma mistura de sementes de linhas puras e a terceira consistindo de três populações derivadas de propagação em "bulk" de F2 a F7, testadas em locais e anos diferentes. A estabilidade foi avaliada em termos de consistência da ordem no "rank" e a magnitude relativa das variâncias. Em termos de produtividade, quando comparadas em uma série de ambientes, os "bulks" se comportaram melhor que as linhas puras, as quais superaram as misturas. Em relação à estabilidade, os "bulks" superaram as misturas que superaram as linhas puras, evidenciando a relação entre estabilidade e diversidade genética. Allard (1961) conclui que diversidade genética, tanto na forma de heterozigotos quanto de misturas de diferentes genótipos, freqüentemente conduzem à estabilidade em condições de variação ambiental. 
Associação entre diversidade e estabilidade de produção também foi observada no trabalho de Patanothai \& Atkins (1974), comparando híbridos triplos e simples de sorgo. Segundo os autores, é de se esperar uma maior estabilidade nos híbridos triplos pois, sendo o híbrido simples uma população homogênea, a única forma de alcançar estabilidade é através de homeostase individual. Já no caso do híbrido triplo, tanto homeostase individual como populacional podem contribuir para o fenômeno. Resultados semelhantes foram obtidos por Reich \& Atkins (1970) avaliando produção de populações com diferentes graus de diversidade genética a partir de híbridos de sorgo e seus parentais, por Probst (1957) avaliando a produção de diferentes populações compostas por variedades de soja, por Funk \& Anderson (1964) avaliando diferentes populações compostas por diferentes híbridos de milho e por Rowe \& Andrew (1964) avaliando linhagens, híbridos e populações segregantes de milho.

A cooperação de genótipos menos adaptados com genótipos adaptados tornando a população como um todo mais adaptada do que os genótipos constituintes não deve ser encarada como uma regra geral. Competição pode ser um fator importante nesta discussão. Um genótipo com boa performance em uma cultura geneticamente uniforme pode ter baixa performance em misturas devido à competição. Por outro lado um competidor agressivo deve ter maior performance numa cultura heterogênea (Bekele, 1983). Cooperação entre genótipos tem sido atribuída à exploração diferencial de diferentes tipos de habitat (Probst, 1957; Rowe \& Andrew, 1964; Zemede, citado por Bekele, 1983), às interações compensatórias entre indivíduos de uma população geneticamente diversa (Rowe \& Andrew, 1964) e à variação na resistência a pragas e doenças (Probst, 1957; Oka, 1975; Oka 1982).

$\mathrm{Na}$ agricultura autóctone, a importància da relação diversidade-estabilidade no agroecossistema tem sido destacada por vários autores. Harlan (1975) afirma que a variabilidade genética fornece certa segurança contra riscos. Cleveland et al. (1994) destacam a importância das etnovariedades em função da sua maior estabilidade e se baseiam no fato de que agricultores africanos favorecem freqüentemente a estabilidade da produção em detrimento de produções ótimas. Para a agricultura moderna, Oka (1988) 
propõe um esquema de melhoramento que, mesmo uniformizando características de importância agronômica, mantenha as populações de plantas cultivadas num certo nivel de variabilidade suficiente para resistir a certos niveis de estresse ambiental.

No caso de mandioca, poucos estudos foram realizados em relação à homeostase individual e ainda menos em relação à homeostase populacional. A homeostase individual pode ser expressa pela interação genótipo ambiente e alguns trabalhos podem ser encontrados contendo alguns dados desta natureza. Barriga (1980) analisou 12 cultivares comuns amazônicos e não amazônicos em relação à produtividade em diferentes ambientes. Uma alta interação entre genótipos e locais, genótipos e anos e genótipos, locais e anos foi observada. Foram encontrados cultivares mais adaptados a ambientes mais tecnificados e a ambientes menos tecnificados com alto grau de previsibilidade. Observou-se também cultivares com produção mais estável. A chuva parece ter sido o fator mais importante na interação entre anos e genótipos. Observou-se ainda que genótipos mais estáveis tiveram produções médias abaixo da média geral, que é uma tendência geral observada por vários autores para diversas culturas. Kawano et al. (1987) também observaram interação significativa entre clones de mandioca e locais para conteúdo de matéria seca das raízes, apesar de que a magnitude do efeito de clones ter sido bem maior. Iglesias et al. (1994a) encontraram entre 15 clones de mandioca avaliados, clones mais adaptados a ambientes mais favoráveis, clones adaptados a ambientes menos favoráveis e clones com adaptação mais ampla em relação a vários caracteres. Em mandioca, altas interações entre genótipo e locais devem ser esperadas pelo fato desta ter sido selecionada para adaptação local (Jennings, 1979). Salick et al. (1997) constataram que entre os Amuesha, os fenótipos de mandioca variaram com elevação, topografia e solos. 


\subsection{Ubatuba}

\subsubsection{Caiçaras e mandioca no município de Ubatuba}

O caiçara é a somatória da cultura indígena, negra, portuguesa e de outras populações, mas é sobretudo um cidadão que mora próximo ao mar da região sudeste do Brasil, e é pescador e agricultor. Possui um rancho de canoa e uma área de agricultura normalmente distante de sua moradia (Vigneron citado por Rodrigues, 1994; Papy, 1957)). De Recife ao Estado de Santa Catarina, a designação caiçara tem o mesmo significado (Papy, 1957). O caiçara possui um grande conhecimento do ambiente que o circunda, sendo capaz de reconhecer aspectos como tipo de solo para plantio, época do ano para retirada da madeira para canoa, assim como a habilidade de diferenciar unidades ecológicas, além de conhecer e utilizar uma série de espécies vegetais para os mais diversos fins (Rossato, 1996).

O cultivo da mandioca em Ubatuba é certamente anterior ao descobrimento do Brasil e as técnicas utilizadas pelos caiçaras são herança indígena e consistem basicamente nas mesmas descritas para a agricultura tropical autóctone (Papy, 1957). Schmidt (1958) afirma que quando os descobridores e os primeiros colonos aqui chegaram, deram com o cultivo da mandioca disperso por área bastante extensa e faz referência a Hans Staden e ao Padre José de Anchieta, os quais descrevem a derrubada do mato, a queima e o plantio da mandioca em Ubatuba, da mesma maneira como descrito por Schmidt (1958) e Papy (1957). Schmidt (1958) ainda faz algumas considerações a respeito da distribuição do cultivo da mandioca no Estado de São Paulo, identificando duas áreas culturais: comunidades que consomem predominantemente farinha de milho e comunidades que consomem predominantemente farinha de mandioca. Segundo ele, tomando-se como base a produção de farinha de mandioca em relação à produção de farinha de milho, o litoral do Estado seria a região típica de cultivo de mandioca, já que quase não era produzida farinha de milho. A medida que se caminhava do litoral em direção ao planalto paulista notava-se um aumento da produção de farinha 
de milho em relação à farinha de mandioca, sendo que no Vale do Paraíba, quase inexistia fabricação de farinha de mandioca, pelo menos na época em que Schmidt fez seus estudos.

Ubatuba foi região agrícola no passado. Café no século passado e cana de açúcar ainda anteriormente foram extensamente plantados na região, tendo o café sido plantado das planícies aluviais à beira mar até cerca de 400 a 500 metros serra acima (Papy, 1957).

É extremamente relevante para o presente trabalho a descrição obtida por Schmidt (1958) da agricultura local dada por um agricultor típico da época. A mandioca, nesta descrição, pode ser plantada a partir do mês de maio até novembro, pois em dezembro há grande mortalidade decorrente do excesso de chuvas, que atingem o auge nesta época. Plantava-se mandioca tanto em solos fracos, como solos arenosos bem próximos à praia, quanto em solos mais férteis e argilosos nos morros, havendo resposta positiva da mandioca quando plantada em solos mais fortes e podendo ser plantada em consórcio com outras espécies como o milho. Plantio de mandioca em solos que tinham a tendência de ser encharcados exigiam o cuidado de se fazer um monte de terra mais alto que o nível médio da superficie do solo para cada planta para que a água não encharcasse a raiz e causasse o seu apodrecimento. O plantio podia ser feito tanto em roçados de capim gordura e sapé como em capoeiras, sendo o fogo utilizado como forma de limpeza do terreno, aliado eventualmente à foice ou, as vezes, enxada. As manivas, segundo a descrição do agricultor, eram compradas em feixes, quando da primeira plantação, e decepadas em pedaços menores contendo no mínimo uns cinco olhos (gemas). A maniva era plantada deitada nas covas abertas no solo ou fincada nas valas deixando cerca de três olhos aparecendo. Três a quatro limpas na roça seriam necessárias, dependendo da fertilidade do solo. Após estas limpas (cerca de dois anos) não era mais necessário este tipo de cuidado. $\mathrm{O}$ agricultor recomendava decepar o excesso de ramificações, deixando apenas um ramo principal para "desembaraçar as ramas".

Algumas ramas (etnovariedades) cultivadas pelo agricultor consultado tinham os nomes de Santista, Santa, Mucaé, Aipim-branca, Landi-branca, Landi-preta ou Landizinha, Roxinha, Ruivinha e Ilhéu. A rama Santista é tida pelo agricultor como vinda 
de Santos cerca de 15 anos antes da entrevista (década de 30). Dos inimigos da cultura de mandioca foram citados a formiga saúva, a qual era combatida eficientemente apenas com formicida e eventualmente com o caldo da Mandioca-Brava despejado no formigueiro; o porco-do-mato ou cateto, que podia estragar uma roça completa; o ratode-casa e o saporê. Segundo o agricultor, o saporê é um bolor (fungo) de solo que ataca indiscriminadamente espécies como a mandioca, o café e outras plantas e pode ser classificado como saporê de fio ou saporê de pedra. Quando ataca a mandioca, o saporê causa o apodrecimento da raiz. O controle do saporê poderia ser feito queimando a área atingida e plantando cana no lugar, a qual crescia sem muito vigor, mas acabava com o saporê. Foi descrito também um caso de uma roça no Puruba ter sido totalmente atacada por uma lagarta. Muitas vezes a má produção de determinada roça era atribuida a causas sobrenaturais como mau-olhado etc. A mandioca era cultivada basicamente para farinha, polvilho ou mesa.

\subsubsection{Parque Estadual da Serra do Mar}

O Parque Estadual da Serra do Mar foi criado em 1977 com a finalidade de assegurar a integral proteção à flora, fauna, às belezas naturais bem como garantir sua utilização a objetivos educacionais, recreativos e científicos. Por motivos administrativos o Parque foi subdividido em núcleos. O Parque foi tombado 1985 pelos seus atributos geológicos, geomorfológicos e paisagísticos e ainda como banco genético tropical. $\mathrm{O}$ regulamento dos parques estaduais paulistas de 1986 prevê que as autoridades devem manter os parques intocados, sendo proibidas coletas de frutos, sementes, raízes ou outros produtos, assim como proceder adubações, correções e recuperação do solo. A resolução do Instituto Brasileiro do Meio Ambiente e Recursos Naturais Renováveis (IBAMA) de 1991 proíbe o corte e exploração da floresta primária de mata atlântica no

Estado de São Paulo (Mota et al., 1992). O núcleo Picinguaba (área do presente trabalho) foi desapropriado em 1984 e previa-se a fixação da população autóctone de 
caiçaras, tendo sido reativada uma antiga casa de farinha na Fazenda da Caixa (Melo Neto, 1992). 


\section{MATERIAL E MÉTODOS}

\subsection{Descrição da região}

Ubatuba localiza-se no litoral norte do Estado de São Paulo na latitude $22^{\circ} 22^{\prime} \mathrm{S}$ e longitude 4507' W (Projeto RadamBrasil, 1983). A região de estudo localiza-se a partir de $30 \mathrm{~km}$ ao norte do centro urbano do município até a divisa com o Estado do Rio de Janeiro, acompanhando a rodovia BR-101 (Rio-Santos).

O relevo da área de estudo engloba feições morfológicas com forte controle es rutural com escarpas festonadas, cristas, esporões e comijas, com incisões de drenagem entre 344 e $446 \mathrm{~m}$ e declividades superiores a $37^{\circ}$. Geologicamente, as escarpas da serra do mar são compostas por granitos e gnaisses do pré-cambriano (Carvalho et al., 1992), mais especificamente charnockitos, monzonitos, granodioritos, granulitos charnockiticos, leucogranitos e granitóides, segundo o Projeto RadamBrasil (1983). Os solos associados com o relevo forte ondulado e ondulado variam de Cambissolos álicos de textura média a argilosa até Latossolos Vermelho-Amarelos mais desenvolvidos também de textura média a argilosa, ambos possuindo horizonte A moderado e proeminente (Projeto RadamBrasil, 1983; Rossi et al., 1991). Na Fazenda da Caixa, foram encontrados associados a relevo ondulado e forte ondulado uma associação entre Latossolo Vermelho-Amarelo e Solos Litólicos (Carvalho et al., 1992).

O clima, segundo a classificação de Koeppen é Cła, clima úmido com temperaturas brandas, na qual a média do mês mais quente é superior a $22^{\circ} \mathrm{C}$ (Carvalho et al., 1992). As precipitações variam entre 1500 a $2500 \mathrm{~mm}$ chegando a $4300 \mathrm{~mm}$ nos contrafortes da serra do mar (Projeto RadamBrasil, 1983). 
A área de estudo é coberta por floresta ombrófila densa submontana segundo a classificação do Projeto RadamBrasil (1983), típica de áreas nas quais anualmente ocorrem de 0 a 60 dias secos, ocorrendo sobre litologia variada. Segundo Carvalho et al. (1992) e a classificação do boletim 12 do Serviço Nacional de Pesquisas Agronômicas (Brasil, 1960) a vegetação da área é denominada floresta latifoliada tropical, variando sua composição em função do substrato e do relevo.

O Núcleo Picinguaba tem uma população composta de $80 \%$ de pessoas originárias da região e apresentam fortes traços da cultura caiçara existente no Sudeste brasileiro (Rodrigues, 1994). O sertão do Puruba (localizado nos limites do Parque) e a Fazenda da Caixa (localizada bem no interior do Parque) tem populações que praticam agricultura e dependem desta atividade em diferentes graus (Rossato, 1996).

\subsection{Escolha do local, dos agricultores e das roças}

A implantação da reserva e do Parque Estadual teve forte impacto na agricultura local, pois a sua realização tornou-se ilícita, já que para tanto é necessária a derrubada de vegetação, o que é expressamente proibido pela lei. A agricultura autóctone é praticada, portanto, de modo encoberto na tentativa de evitar possiveis repressões legais. Entretanto, em alguns locais as autoridades do parque permitiram a realização de agricultura desde que não houvesse retirada de vegetação para abertura de novas roças, restringindo assim a área que os agricultores tinham para sua prática, o que causou a necessidade de redução do tempo de pousio entre um cultivo e outro. Pode-se, então, encontrar agricultores que praticam agricultura tradicionalmente e outros cuja prática da agricultura foi alterada pelo fato de estarem restritos a uma área pequena.

A escolha dos agricultores com os quais se realizou o trabalho seguiu os seguintes critérios: (1) a anuência dos mesmos em permitir e colaborar com a pesquisa, (2) que tivessem conhecimento e experiência necessários para que esse sistema de agricultura fosse bem representado e, portanto, procurou-se escolher agricultores mais velhos e experientes e (3) que pudessem ser divididos em agricultores que praticam agricultura 
cujo manejo é tradicional e agricultores que praticam agricultura cujo manejo é alterado. Para isso, foi estabelecido um outro critério para separar o que seriam roças alteradas e roças tradicionais. $\mathrm{O}$ critério se baseou principalmente no tempo em que as roças ficaram abandonadas antes que novo cultivo fosse estabelecido ou o tempo de descanso. Segundo os próprios agricultores, periodos superiores a cinco anos são recomendáveis para que se retome a uma área que já tenha sido cultivada e implantar nova roça e periodos abaixo de três anos são criticos para um novo cultivo.

Baseando-se nestes critérios pode-se definir quatro agricultores com os quais se faria a pesquisa. O primeiro deles, DF, tem suas roças no sertão da praia de Puruba, cerca de $30 \mathrm{~km}$ do centro urbano de Ubatuba. Sertão, para os caiçaras, significa os contrafortes da serra do mar, na direção oposta à praia. Foram escolhidas deste agricultor 2 roças, DFG e DFP, as quais foram implantadas em capoeiras (vegetação em estágio de sucessão secundária) com cerca de 20 anos. $O$ segundo, AG, situado no sertão de Ubatumirim, possuía roças também implantadas após o corte de capoeiras com mais de cinco anos de idade. Deste agricultor tentou-se estudar apenas uma roça, o que não foi possível. Maiores detalhes a este respeito serão discutidos adiante. Ubatuminim é um bairro de Ubatuba situado cerca de $7 \mathrm{~km}$ da praia do Puruba em direção ao Rio de Janeiro. O terceiro e o quarto agricultor, FA e FO, cultivam suas roças na Fazenda da Caixa, dentro do núcleo Picinguaba numa área restrita, e o fazem com permissão das autoridades do núcleo. Ambos possuem poucas áreas de cultivo abandonando-as alternadamente por no máximo 2 anos quando então retornam e fazem nova roça. Foram escolhidas uma roça de cada agricultor. $\mathrm{O}$ núcleo Picinguaba situa-se cerca de $10 \mathrm{~km}$ da praia de Ubatumirim em direção ao Rio de Janeiro.

As duas roças de DF, DFG e DFP, e as roças de AG foram então classificadas como roças tradicionais, enquanto que as roças de FA e FO foram classificadas como roças alteradas. Do mesmo modo, DF e AG são agricultores que praticam agricultura tradicional e FA e FO são agricultores que praticam agricultura com manejo alterado. Com exceção de DFG e DFG, as roças foram designadas pelos mesmos nomes dos agricultores. 


\subsection{Amostragem de plantas para análise de isoenzimas e amostragem de solos}

A amostragem de plantas de mandioca para realização de eletroforese de isoenzimas foi realizada aleatoriamente de modo a representar o melhor possível a diversidade genética contida nas roças sem que houvesse o privilégio de determinado genótipo em detrimento de outro. Para isso, entrou-se na roça acompanhado do agricultor, sendo que a cada 5 passos escolhia-se a planta mais próxima, pedia-se ao agricultor que a identificasse de acordo com sua classificação, cortava-se uma maniva de aproximadamente $60 \mathrm{~cm}$ a qual era imediatamente marcada com o nome dado pelo agricultor. A roça foi percorrida em transectos na tentativa de cobri-la por igual. $O$ critério utilizado como orientação para definir o número de plantas que deveriam ser amostradas por roça se baseou no número de etnovariedades que o agricultor afirmava previamente ter plantado na roça a ser amostrada. O resultado deste número multiplicado por dez era aproximadamente o número de plantas que deveriam ser amostradas. Este número foi corrigido pelo fato de que a amostragem era interrompida quando constatado que a roça já havia sido totalmente percorrida. Assim, roças menores contribuíram com menor número de plantas que roças maiores. A quantidade de plantas amostradas por roça pode ser observada na Tabela 2 .

Tabela 2- Número de plantas amostradas nas roças para realização realização de eletroforese de isoenzimas.

\begin{tabular}{|l|c|c|c|c|c|}
\hline Roça & DFG & DFP & AG & FA & FO \\
\hline No de plantas & 62 & 37 & 52 & 45 & 34 \\
\hline
\end{tabular}

A amostragem foi realizada no verão e outono de 1997, as amostras foram levadas para o Departamento de Genética da ESALQ/USP e plantadas em saquinhos plásticos em três repetições para que, no caso da ocorrência de alguma mortalidade, a chance da perda de uma amostra fosse reduzida. As plantas cresceram dentro de casa de vegetação com 
irrigação automática e frequentemente eram pulverizadas com um bactericida, Agrimicina, na proporção de $240 \mathrm{~g} / 1001$ de água, principalmente no final do inverno quando as novas folhas começaram a brotar e as condições de temperatura favoreciam a doença. Foi também aplicada meia colher de sobremesa de carbofuran em cada saquinho para controlar cochonilhas, as quais desfiguravam folhas novas e as tomavam inúteis para eletroforese. A roça DFP foi amostrada no outono de 1997 e, devido à falta de disponibilidade do agricultor, não foi possivel a identificação de cada individuo segundo a classificação local.

Alèm da amostragem de plantas, realizou-se uma amostragem de solos. As amostras foram colhidas de 0 a $20 \mathrm{~cm}$ da superficie do solo. Três pontos foram amostrados no terço superior, três no terço médio e três no terço inferior, totalizando nove pontos por roça. Estas amostras foram analisadas no Departamento de Quimica da Escola Superior de Agricultura "Luiz de Queiroz" quanto aos seus teores de fósforo (P), magnésio $(\mathrm{Mg})$, cálcio $(\mathrm{Ca})$ e potássio $(\mathrm{K})$ pelo método da resina; enxofre $(\mathrm{S})$ pelo método de turbidimetria por acetato de cálcio; matéria orgànica (\%MO) pelo método da solução de dicromato de sódio $4 \mathrm{~N} \mathrm{em}_{2} \mathrm{SO}_{4}, \mathrm{pH}$ em $\mathrm{CaCl}_{2}$; acidez potencial $(\mathrm{H}+\mathrm{Al})$ pelo metodo de solução tampão SMP; capacidade de troca de cátions $(T)$ e saturação de bases $(\mathrm{V} \%)$.

\subsection{Amostragem de plantas para avaliação morfológica e morfométrica}

Foi decidido proceder a avaliação morfológica localmente nas roças e não num campo experimental em Piracicaba. Essa decisão foi tomada pelo fato de que em Piracicaba há uma alta incidência de bacteriose causada por Xanthomonas campestris pv manihotis (Arthaud-Berthet) Starr, a qual já se mostrou capaz de interferir deleteriamente em alguns experimentos. A bacteriose pode desfigurar alguns individuos mais suscetíveis provocando uma variància ambiental indesejável que poderia comprometer os resultados e sua interpretação, além de causar uma certa mortalidade de plantas. Esta bacteriose praticamente não ocorre em Ubatuba em vista das condições ambientais desfavoráveis 
para seu desenvolvimento, como afirma Valle ${ }^{6}$. Entretanto, foi necessário acercar-se de certos cuidados para viabilizar a avaliação destes caracteres na roça. $O$ principal cuidado que se tomou reside na escolha dos caracteres para avaliação. Caracteres muito suscetiveis à influência do ambiente são inadequados para esta tarefa, pois a variação ambiental em uma roça não é devidamente controlada, o que certamente acarretaria uma série de vieses comprometendo a análise. A solução foi a escolha de caracteres pouco influenciados pelo ambiente. Desse modo, pode-se admitir que a variação que se está observando tem um alto componente genético.

Os caracteres utilizados por Cury (1993) apresentam boas condições de serem avaliados nas roças, pois atendem os requisitos mencionados acima. Cada caráter morfológico possui classes fenotípicas, as quais servem de referência para classificar determinado indivíduo. Abaixo estão listados os caracteres e suas classes fenotípicas.

M1- Cor do broto foliar.

1- Verde

2- Verde claro com manchas roxas.

3- Verde escuro com manchas roxas.

4- Verde escuro.

5- Roxo esverdeado.

M2- Cor da folha adulta.

1- Verde claro.

2- Verde escuro.

3- Roxo.

${ }^{6}$ Vallc, T.L. (Instituto Agronômico dc Campinas, S. dc Raizcs c Tubćrculos). Comunicação pcssoal, 1998. 
M3- Cor do peciolo de folhas adultas.

1 - Verde.

2- Verde avermelhado.

3- Vinho.

4- Roxo.

M4- Cor da base da nervura da folha.

1- Verde.

2- Verde arroxeado.

3- Vinho.

4- Roxo.

M5- Morfologia do lóbulo foliar.

1- Lanceolada.

2- Linear.

3- Oblonga.

4- Obovada.

M6- Sinuosidade do lóbulo foliar.

1- Lisa.

2- Intermediária.

3- Forte.

M7- Pubescência.

1- Sem pelos.

2- Poucos pelos.

3- Muitos pelos.

M8- Número de lóbulos da folha.

M9- Comprimento do peciolo.

M10-Comprimento da folha

M1 1- Comprimento do lóbulo médio

M12- Largura do lóbulo médio.

M13-Comprimento do lóbulo à direita do lóbulo médio. 
M14- Largura do primeiro lóbulo à direita do lóbulo médio.

M15- Cor do caule jovem.

1- Verde.

2- Verde claro com manchas roxas.

3- Verde escuro com manchas roxas.

4- Verde escuro.

5- Roxo esverdeado.

M16- Cor do caule adulto sem a película externa.

1 - Verde.

2- Verde amarelado.

3- Verde avermelhado.

4- Verde escuro.

M17- Proeminència das cicatrizes foliares.

1- Pouca.

2- Média.

3- Muita.

M18- Pedúnculo - Corpo lenhoso que liga a raiz e à maniva.

1 - Presente.

2- Ausente.

M19- Cintas - Presença de estrangulamentos ao longo das raízes.

1- Presente

2- Ausente.

M20- Cor da película externa da raiz.

1- Creme.

2- Marton claro.

3- Marron escuro.

4- Roxa. 
M21- Cor da casca da raiz sem a película externa (Feloderma).

1- Branca

2- Creme.

3- Amarela.

4- Rosa.

5- Roxa.

M22- Cor da polpa da raiz.

1- Branca

2- Creme.

3- Amarela.

4- Rosa.

5- Roxa.

$\mathrm{O}$ esquema de amostragem foi o mesmo utilizado para a amostragem anterior. A roça foi percorrida em transectos visando sua ampla cobertura. A cada cinco passos a planta mais próxima era escolhida e seus caracteres quantificados e anotados. $\mathrm{O}$ tamanho da amostra se baseou no tamanho da roça. Tentou-se padronizar, nesta amostragem, a regiāo da planta da qual se retirava folhas e avaliava-se caracteres do caule. Pode-se observar na Tabela 3 o número de plantas amostradas por roça para avaliar caracteres morfológicos e morfométricos.

Tabela 3- Número de plantas amostradas por roça para análise morfológica e morfométrica

\begin{tabular}{|l|c|c|c|c|c|}
\hline Roças & AG & DFG & DFP & FA & FO \\
\hline No de plantas & 50 & 52 & 30 & 40 & 41 \\
\hline
\end{tabular}

Além destas amostras as roças foram medidas com trena para a obtenção de uma estimativa de suas áreas (Tabela 4). 
Tabela 4 - Estimativa da área em $\mathrm{m}^{2}$ das roças estudadas.

\begin{tabular}{|l|c|c|c|c|c|}
\hline Roça & FA & FO & AG & DFG & DFP \\
\hline Área $\left(\mathrm{m}^{2}\right)$ & 4500 & 1700 & 20000 & 1900 & 450 \\
\hline
\end{tabular}

As amostragens para isoenzimas e para caracteres morfológicos foram realizadas em periodos diferentes porque na época em que se fez a primeira, estava-se iniciando o contato com os agricultores e não houve a possibilidade de evitar que a amostragem para caracteres morfológicos, caso se insistisse em realizá-la, coincidisse com o periodo de inverno, quando as plantas perdem suas folhas, o que certamente atrapalharia a avaliação morfológica. Assim, as amostragens para isoenzimas foram realizadas no inicio de 1997 e em julho de 1997 e as amostragens para caracteres morfológicos em novembro de 1997. Deste fato decorreu que as roças AG, FA e FO, em novembro de 1997, haviam sido totalmente colhidas, a roça DFP parcialmente colhida e a roça DFG atacada por saporém. As roças DFG e DFP, apesar de um pouco alteradas, foram coletadas sem maiores problemas, pois grande parte destas ainda estava intacta. As roças FA e FO, apesar de colhidas, foram replantadas utilizando o mesmo conjunto de variedades em locais distando poucos metros da roça anterior. Considerou-se que nestas roças, a população de mandiocas foi transferida de um local para outro, já que estes agricultores não possuiam outras roças de onde tirar manivas para plantar. Já no agricultor da roça AG, optou-se por realizar a amostragem de caracteres morfológicos em uma outra roça já existente na época da primeira amostragem, roça esta situada em local semelhante àquele onde estava a roça amostrada para realização de isoenzimas, porém distando mais de 500 metros da primeira. Não foi amostrado solo nesta roça. 


\subsection{Eletroforese de isoenzimas}

\subsubsection{Sistemas isoenzimáticos}

Os sistemas isoenzimáticos testados foram baseados na recomendação de Peroni ${ }^{7}$, que já havia testado vários sistemas e tampões em etnovariedades de mandioca coletadas em Arin, litoral sul de São Paulo. Os principais critérios para a escolha dos sistemas que deveriam ser efetivamente utilizados foi a resolução da técnica, presença de polimorfismo, repetibilidade e interpretabilidade. Na Tabela 5 estão listados os sistemas testados e utilizados.

Tabela 5- Enzimas testadas e utilizadas com seus respectivos códigos e siglas.

\begin{tabular}{|l|l|l|}
\hline Enzima & Código & Sigla \\
\hline Leucina Aminopeptidase & E.C.3.4.11.1 & LAP \\
Alfa esterase & E.C.3.1.1.1 & $\alpha-E S T$ \\
Catalase & E.C.1.11.1.6 & CAT \\
Fosfoglucomutase & E.C.2.7.5.1 & PGM \\
Fosfoglucoes isomerase & E.C.5.3.1.9 & PGI \\
Enzima málica & E.C.1.1.1.40 & EM \\
Glucose-6-fosfato desidrogenase & E.C.1.1.1.49 & G6PDH \\
Isocitrato desidrogenase & E.C.1.1.1.42 & DH \\
Malato Desidrogenase & E.C.1.1.1.37 & $\mathrm{MDH}$ \\
Xiquimato Desidrogenase & E.C.1.1.1.25 & SKDH \\
\hline
\end{tabular}

Os sistemas utilizados foram $\mathrm{MDH}, \mathrm{SKDH}, \mathrm{LAP}$ e PGI.

\footnotetext{
${ }^{7}$ Peroni, N. (Deparamento de Genćtica da Escola Supcrior de Agricultura "Luiz de Quciroz"). Comunicação pessoal, 1996.
} 


\subsubsection{Gel de amido}

Os geis foram preparados com uma mistura de penetrose 30 e amido da marca Sigma na proporção $2: 1$ e em concentração de $12 \%$. Dependendo do sistema utilizado o gel era preparado com um tipo de tampão. Para os sistemas $\mathrm{MDH}$, SKDH e LAP foi utilizado o tampào CM (Clayton \& Tretiak, 1972) e para o sistema PGI, os sistemas A+B na proporção 1:9 para o gel e somente o tampão A na cuba (Scandalios, 1969). Abaixo, pode-se encontrar a composiçào destes tampões.

Tampão A (pH 8,3)

Hidróxido de litio $2,098 \mathrm{~g}$

Ácido bórico $11,748 \mathrm{~g}$

$\mathrm{H}_{2} \mathrm{O}$ q.s.p. $1000 \mathrm{ml}$

Tampão B (pH 8,3)

Tris

Ácido cítrico $6,178 \mathrm{~g}$

$\mathrm{H}_{2} \mathrm{O}$ q.s.p. $1,68 \mathrm{~g}$ $1000 \mathrm{ml}$

Tampão citrato de morfolina (CM) para cuba $(\mathrm{pH} 6,1)$

Ácido cítrico (0,040M) $8,41 \mathrm{lg}$

N-(3-Aminopropyl) morfolina (0,068M) $10 \mathrm{ml} / 1$

Para o gel, dilui-se o tampão para cuba na proporção 1:20.

O gel era preparado aquecendo-se cerca de um quarto da quantidade de tampão até a ebulição (cerca de 2 minutos) em forno de microondas. Paralelamente, homogeneizavase a mistura amido-penetrose e o restante do tampão frio num kitassato. Adicionava-se o tampão aquecido ao kitassato contendo a mistura homogeneizada, agitando novamente 
até a homogeneização da nova mistura. Levava-se o kitassato ao forno de microondas por 1 minuto e 45 segundos no caso do tampão $\mathrm{CM}$ e 1 minuto e 30 segundos no caso do tampão $\mathrm{A}+\mathrm{B}$, interrompendo o aquecimento a cada 15 segundos para agitação. A mistura era então colocada numa placa de vidro com barras de acrilico formando uma moldura de $15,8 \times 13 \times 1,3 \mathrm{~cm}$ e resfriado a temperatura ambiente por cerca de uma hora antes de ser coberto com filme plástico e levado à geladeira.

\subsubsection{Eletroforese}

A técnica de eletroforese se inicia com a extração das enzimas das folhas jovens recém expandidas ou ainda em fase de expansão. Estas folhas eram obtidas das plantas cultivadas em sacos plásticos em casa de vegetação. Cada folha, representando um individuo, era cortada eliminando o peciolo e então disposta em uma placa de acrilico com vários recipientes còncavos próprios para maceração. Antes da maceração eram adicionadas 2 a 4 gotas de tampão de extração, dependendo do volume das folhas em cada recipiente. Procedia-se a maceração até a completa homogeneização do tecido. Em cada recipiente eram colocados pedaços de papel de filtro de $4 \times 7 \mathrm{~mm}$ que absorviam o macerado. Estes papéis eram colocados verticalmente lado a lado no gel. Para isso, o gel era cortado cerca de $4 \mathrm{~cm}$ do seu maior lado, sendo estas partes separadas para facilitar a colocação dos papéis. Eram colocados por gel de 20 a 24 papéis, representando 20 a 24 individuos. Colocava-se também dois destes papéis embebidos em solução de azul de bromofenol $(0,04 \mathrm{~g} / 100 \mathrm{ml})$ nas extremidades do gel, para marcar a linha de frente de migração e ser utilizado como referência desta migração. $O$ gel era unido num único elemento e levado ao equipamento de eletroforese, a qual era realizada até que a linha de frente atingisse cerca de $8,0 \mathrm{~cm}$. Os geis com tampão $\mathrm{CM}$ eram corados com mais de um sistema e, por isso eram cortadas 4 fatias (uma de reserva), as quais seriam coradas posteriormente. Já o gel que utilizava o tampão $A+B$ era corado apenas com o sistema PGI e, portanto, apenas uma fatia integral era suficiente. Os sistemas eram preparados previamente, banhavam-se os géis com o sistema adequado e deixavam-se os géis 
revelando em estufa escura a $37^{\circ} \mathrm{C}$. Corados, os géis tinham as bandas representadas num zimograma em papel milimetrado, o qual era desenhado respeitando-se as distâncias entre as bandas e a origem e entre bandas, assim como a distância entre a linha de frente e a origem.

Os sistemas e o tampão de extração utilizados são descritos abaixo:

LAP (Alfenas et al, 1991)

Tampão Tris-maleato ( $\mathrm{pH} 5,2-0,2 \mathrm{M}) \quad 50 \mathrm{ml}$

L-leucyl $\beta$ - naftilamida $\quad 0,02 \mathrm{~g}$

Fast Gamet GBC $\quad 0,025 \mathrm{~g}$

Dissolver o substrato em $10 \mathrm{ml}$ de solução de metanol $10 \%$ por 5 minutos.

SKDH (Alfenas et al., 1991)

$\begin{array}{ll}\text { Ácido xiquímico } & 0,05\end{array}$

$\mathrm{NADP}+\quad 1,0 \mathrm{ml}(10 \mathrm{mg})$

PMS 1,0ml (lmg)

MTT ou NBT $\quad 1,0 \mathrm{ml}(1 \mathrm{mg})$

Tris-HCl $(0,1 \mathrm{M}-\mathrm{pH} 8,5) \quad 50 \mathrm{ml}$

MDH (Brewer \& Sing, 1970 modificado)

NAD

$0,033 \mathrm{~g}(3,3 \mathrm{ml})$

PMS

$0,0015 \mathrm{~g}(1,5 \mathrm{ml})$

MTT ou NBT

$0,0125 \mathrm{~g}(1,2 \mathrm{ml})$

Tampão Tris - Ácido málico (pH 7,0)

$50 \mathrm{ml}$ 
PGI (Alfenas et al. 1991)

Frutose-6-fosfato

NADP+

MTT ou NBT

PMS

$\mathrm{MgCl} 2(1 \%)$

Tris- $\mathrm{HCl}(0,1 \mathrm{M}-\mathrm{pH} 8,0)$

Glucose -6-fosfato desidrogenase (G6PDH)

Tampào de extraçào (Scandalios, 1969)

Sacarose

PVP (Polivinil pirrolidona)

EDTA

Albumina bovina

Tris- $\mathrm{HCl}(0,1 \mathrm{M}-\mathrm{pH} 7,5)$
$0,0375 \mathrm{~g}$

$1,0 \mathrm{ml}$ (10mg)

$1,0 \mathrm{ml}$ (10mg)

$1,0 \mathrm{ml}(1,0 \mathrm{mg})$

$1,0 \mathrm{ml}$ (10mg)

$50 \mathrm{ml}$

$0,01 \mathrm{ml}$ (10 unid.)

$6,892 \mathrm{~g}$

$1,20 \mathrm{~g}$

$0,067 \mathrm{~g}$

$0,2 \mathrm{~g}$

$200 \mathrm{ml}$

\subsection{Análise dos dados de solo}

A análise dos dados de solo foi a primeira a ser realizada. $\mathrm{O}$ objetivo desta análise foi identificar dentre as variáveis que compõe a análise do solo, $\mathrm{Ca}, \mathrm{Mg}, \mathrm{S}, \mathrm{P}, \mathrm{K}, \% \mathrm{MO}$, $\mathrm{V} \%, \mathrm{~T}, \mathrm{H}+\mathrm{Al}$ e $\mathrm{pH}$, quais seriam as que mais estariam contribuindo para diferenciar as roças consideradas alteradas das tradicionais. Para isso empregou-se o método de componentes principais ou simplesmente PCA.

A análise de PCA é uma forma de análise multivariada de dados que tem como objetivo tomar $\mathrm{p}$ variáveis $\mathrm{X} 1, \mathrm{X} 2, \mathrm{X} 3, \ldots, \mathrm{Xp}$ e encontrar combinações destas de modo a produzir eixos $Z 1, Z 2, Z 3, \ldots, Z p$ que não sejam correlacionados. A não existência de correlação é uma propriedade interessante, pois significa que os índices estão medindo diferentes "dimensões" dos dados. Os eixos são ordenados de modo que $\mathrm{Zl}$ responda pela maior parte da variação, $Z 2$ responda pela segunda maior parte da variação e assim 
por diante até $\mathrm{Zp}$, o qual responde pela menor parte da variação. Para que o PCA seja eficiente espera-se que a maior parte da variação se encontre nos primeiros eixos, sendo possivel considerar a parte da variação existente nos outros eixos negligenciável e, portanto, as variáveis analisadas possam ser adequadamente representadas por 2 ou 3 componentes principais (Manly, 1994).

A "matéria prima" da análise de PCA é uma matriz de covariància construída com os dados originais. Entretanto, muitas vezes as variáveis são medidas em unidades ou escalas diferentes. Como exemplo, pode-se imaginar uma situação em que uma dimensão é medida em centimetros e outra em metros. Neste caso, se ambas possuírem tamanhos semelhantes, as medidas tomadas em centímetros deverão possuir uma maior média e uma maior variància que aquela tomada em metros, o que causaria uma séria distorção. No caso dos dados de solo, há variáveis em ppm, meq/100 g de solo, $\mathrm{pH}$ etc. Para corrigir possiveis vieses causados simplesmente pelo fato de haver medidas com unidades e/ou escalas diferentes, pode-se transformar os dados em função de sua média e seu desvio padrão (Manly, 1994),

$\mathrm{Z}=\mathrm{X}_{\mathrm{ij}}-\bar{X}_{\mathrm{j}} / \mathrm{s}_{\mathrm{j}}$

onde s é o desvio padrão do conjunto de dados.

Deste modo, todos os dados serão expressos em unidades de desvio padrão, possuindo média igual a zero e desvio padrão igual a 1 . Uma alternativa é a construção de uma matriz de correlações ao invés de uma matriz de covariâncias, já que a primeira pode ser interpretada como uma matriz de covariàncias construida com dados transformados (Manly, 1994).

Um PCA foi realizado com os dados referentes às variáveis de solo e, a partir deste PCA, foi construído um gráfico biplot, o qual contém todas as informações necessárias para interpretar a análise. Além do PCA, foram realizadas algumas análises de variància com algumas variáveis de solo, escolhidas baseando-se na interpretação do PCA, para 
verificar a significància das diferenças entre as roças quanto a estas variáveis. $\mathrm{O}$ biplot foi construido com o programa estatistico Fitopac versão 1.0.

\subsection{Análise dos dados obtidos com as isoenzimas}

Após a obtenção das bandas isoenzimáticas de todos os individuos coletados para cada sistema, foram criados dados de presença e ausència (binários) de bandas para cada individuo em cada sistema isoenzimático. Primeiramente, foi definido o número de bandas em cada sistema isoenzimático encontrado na população total, ou seja, envolvendo todas as roças. Feito isto, cada individuo foi identificado segundo a presença e ausència destas bandas. Para isso, foi atribuido o número 1 para bandas presentes e o número zero para bandas ausentes. Obteve-se, para cada roça, matrizes de dados de presença e ausência (variàveis binárias), cujas linhas representavam os individuos amostrados e as colunas as bandas de cada sistema isoenzimático. Estas matrizes foram a base para as análises dos dados obtidos com isoenzimas.

\subsubsection{Construção de dendrogramas por roça}

A partir das matrizes de presença e ausência foi possivel a construção de matrizes de similaridade, as quais nada mais são do que o conjunto de comparações entre todos individuos de uma roça tomados dois a dois. Compara-se o grau de similaridade entre dois individuos através de um indice de similaridade. $\mathrm{O}$ indice de similaridade escolhido foi indice de concordància simples ou "simple matching" (o qual varia de 0 a 1 ), que corresponde à proporção de bandas coincidentes entre dois individuos em relação ao número de coincidências mais o número de discordâncias. Se temos, por exemplo, dois individuos avaliados através de 6 bandas, pode-se representa-los como no exemplo da Tabela 6. 
Tabela 6 - Exemplo de dados de presença e ausência de bandas de dois individuos

\begin{tabular}{|c|c|c|c|c|c|c|}
\hline Individuos & bandal & banda2 & banda3 & banda4 & banda5 & banda6 \\
\hline $\mathrm{X}$ & 1 & 0 & 0 & 1 & 0 & 1 \\
\hline $\mathrm{Y}$ & 0 & 0 & 1 & 0 & 0 & 1 \\
\hline
\end{tabular}

Baseando-se na Tabela acima, o número de bandas que o individuo $\mathrm{X}$ e $\mathrm{Y}$ tem em comum é 1 e é representado por a. $\mathrm{O}$ número de bandas presentes no individuo $\mathrm{X}$ e ausentes no individuo $\mathrm{Y}$ è 2 e è representado por $\mathrm{b}$. $\mathrm{O}$ número de bandas presentes no individuo $\mathrm{Y}$ e ausentes no individuo $\mathrm{X}$ é 1 e é representado por $\mathrm{c}$. $\mathrm{O}$ número de casos em que ambos não possuem bandas è 2 e é representado por $\mathrm{d}$. Para calcularmos o valor do indice de similaridade "simple matching" entre $\mathrm{X}$ e $\mathrm{Y}$ basta usarmos a seguinte fórmula.

$\mathrm{SM}(\mathrm{XeY})=(\mathrm{a}+\mathrm{d}) /(\mathrm{a}+\mathrm{b}+\mathrm{c}+\mathrm{d})=(1+2) /(1+2+2+1)=3 / 6=0,5$

No caso das roças, foram construidas as matrizes de similaridade apenas com as bandas que se mostraram polimórficas. $\mathrm{O}$ efeito de incluir bandas monomórficas apenas contribui para aumentar a similaridade entre individuos, sendo que este aumento de similaridade ocorre proporcionalmente para todos, não alterando a interpretação do dendrograma. Os dendrogramas foram construidos hierarquicamente pelo método da média aritmética das distâncias entre grupos (UPGMA). O método se inicia formando grupos entre individuos com maior indice de similaridade. Esses grupos são unidos num grupo maior se a distância média entre eles é pequena o suficiente, até que todos os individuos sejam unidos num único grupo (Manly, 1994). Individuos com dados faltantes foram descartados desta análise.

Com as matrizes de similaridade pode-se construir um dendrograma para cada roça, com os quais avaliou-se além do número de fenótipos isoenzimáticos contidos em cada roça, a correspondência destes fenótipos com a classificação do agricultor, já que cada individuo foi identificado pela nomenclatura do agricultor. Para construir estes dendrogramas foi utilizado o programa estatístico Fitopac versão 1.0. 


\subsubsection{Cálculo do índice de Shannon-Weaver para sistemas isoenzimáticos}

O indice de Shannon-Weaver foi calculado separadamente por sistema para que cada roça tivesse sua diversidade isoenzimática expressa por um índice por sistema. Utilizou-se, para isso, a mesma matriz de presença e ausência contruída previamente. Os índices foram normalizados para que variassem de 0 a 1 , dividindo-os pelo logarítmo neperiano do número total de classes (ou a diversidade máxima possível), como foi discutido na revisão bibliográfica. $\mathrm{O}$ número de classes foi determinado contando todas as bandas possiveis em todas as roças conjuntamente para um dado sistema. Se temos, por exemplo, um sistema com 3 bandas, calcula-se o índice de Shannon-Weaver como mostra a Tabela 7. Utilizou-se para o cálculo de todos os índices de Shannon-Weaver o logaritmo neperiano.

Tabela 7 - Exemplo do cálculo do índice de Shannon-Weaver e sua normalização.

\begin{tabular}{|c|c|c|c|c|}
\hline & & & & \\
\hline & banda 1 & banda 2 & banda 3 & \\
\hline $\begin{array}{l}\text { frequêência das bandas } \\
\text { na roça }\left(\mathrm{p}_{\mathrm{i}}\right)\end{array}$ & 0,25 & 0,65 & 0,10 & \\
\hline$p_{i} \ln p_{i}$ & $-0,35$ & $-0,28$ & $-0,23$ & \\
\hline $\mathrm{H}^{\prime}=-\sum \mathrm{p}_{\mathrm{i}} \ln \mathrm{p}_{\mathrm{i}}$ & & & & 0,86 \\
\hline$H_{\text {norm }}^{\prime}=H^{\prime} / \ln 3$ & & & & 0,78 \\
\hline
\end{tabular}

\subsubsection{Construção de dendrograma envolvendo todas as roças}

Para que a distância genética entre roças baseada nas isoenzimas, pudesse ser avaliada, foi necessária a utilização de um método hierárquico utilizado por Consoli (1995). Este método envolve a construção de uma matriz de similaridades com o coeficiente médio dentro de roça e o coeficiente médio entre roças. 
Se temos duas roças com três indivíduos cada, as similaridades podem ser dispostas na matriz abaixo (Tabela 8) da seguinte forma.

Tabela 8- Exemplo de matriz de similaridade entre duas roças com três indivíduos cada.

\begin{tabular}{|c|c|c|c|c|c|c|c|}
\hline & \multicolumn{3}{|c|}{$\mathrm{i}=$ roca $\mathrm{A}$} & \multicolumn{3}{|c|}{$\mathrm{i}=$ roca B } \\
\hline & & $j=1$ & $j=2$ & $j=3$ & $j=1$ & $j=2$ & $j=3$ \\
\hline \multirow{3}{*}{$\mathrm{i}^{\prime}=$ roça A } & $j^{\prime}=1$ & - & & & & & \\
\hline & $j^{\prime}=2$ & $\mathrm{x}$ & - & & & & \\
\hline & $j^{\prime}=3$ & $\mathrm{x}$ & $\mathrm{x}$ & - & & & \\
\hline \multirow{3}{*}{$i^{\prime}=r o c ̧ a B$} & $j^{\prime}=1$ & $\Delta$ & $\Delta$ & $\Delta$ & - & & \\
\hline & $j^{\prime}=2$ & $\Delta$ & $\Delta$ & $\Delta$ & $\mathrm{x}$ & - & \\
\hline & $j^{\prime}=3$ & $\Delta$ & $\Delta$ & $\Delta$ & $\mathrm{x}$ & $\mathrm{x}$ & - \\
\hline
\end{tabular}

$\mathrm{O}$ coeficiente médio dentro de roças $\left(\overline{\mathrm{Sd}}_{i i}{ }^{\prime}\right)$ pode ser calculado com a seguinte fórmula:

- $\bar{S}_{\mathrm{ii}}=\sum(\mathrm{a}+\mathrm{d})_{\mathrm{ij}} / \sum \mathrm{n}_{\mathrm{ij}}$, para i=i'e j \# j', ou simplesmente $\bar{S} \mathrm{~d}_{\mathrm{ii}}=\sum \mathrm{S}_{\mathrm{ij}} / 3$ para i=i'e j \# j' $(\mathrm{x})$, no caso da Tabela acima. Onde $\mathrm{n}_{\mathrm{ij}}$ é o número total de bandas obtidas.

O coeficiente médio entre roças ( $\overline{\text { Seii'}}$ ') pode ser calculado:

- $\overline{\mathrm{Se}}_{\mathrm{ii}}=\sum(\mathrm{a}+\mathrm{d}) / \Sigma n_{\mathrm{ij}}$, para i \# i'e tanto j=j'como j \# j', ou simplesmente $\bar{S}_{\mathrm{ii}}=\sum \mathrm{S}_{\mathrm{ij}}{ }^{\prime} / 9$, para i \# i'e tanto j=j'como j \# j'( $\Delta$ ), no caso da Tabela acima.

A matriz de distâncias pode ser calculada simplesmente subtraindo de 1 cada elemento da matriz de similaridades. A construção de um dendrograma baseado na matriz de distâncias vai considerar apenas as distâncias entre roças sem levar em conta a distância dentro de roças. Entretanto, o que se quer saber é quanto a média das distâncias entre os indivíduos de roças diferentes é superior à média das distâncias entre indivíduos dentro de ambas as roças, valor que pode ser utilizado como medida da distância genética 
real entre roças. Usar apenas as distàncias "entre" cria um problema que pode ser facilmente compreendido se, tomando a matriz de distància como exemplo, for encontrado um coeficiente de distància médio entre duas roças de 0,8 e coeficientes médios dentro de ambas as roças também de 0,8. Embora, na construção do dendrograma a distància entre roças considerada será de 0,8 , o acréscimo da distància entre roças em relação à distància dentro de ambas as roças será nulo, o que leva a crer que a distância real entre as duas é zero, sendo que ambas podem ser consideradas parte da mesma população

Propõe-se, para resolver este problema, que uma nova matriz seja calculada, baseando-se na matriz de distàncias descrita acima. Cada elemento desta matriz referente à distància real entre duas roças diferentes deve ser obtido pela multiplicação da distància entre roças pelo inverso da média das distàncias dentro das duas roças envolvidas. Usando a notação utilizada na matriz anterior pode-se verificar na Tabela 9 como se calcula a nova distància.

Tabela 9- Exemplo do cálculo da distància entre roças em função da média das distàncias dentro de roças.

\begin{tabular}{|l|c|}
\hline & Roça B \\
\hline Roça A & $\overline{\mathrm{Se}}_{\mathrm{ii}} \cdot(\mathrm{AB}) /\left[\left(\overline{\mathrm{Sd}}_{\mathrm{ii}} \cdot \mathrm{A}+\overline{\mathrm{Sd}}_{\mathrm{ii}}, \mathrm{B}\right) / 2\right]$ \\
\hline
\end{tabular}

Deve-se ressaltar que este método proposto é útil para a presente situação em que se quer ter uma idéia de um possível distanciamento genético real das roças alteradas em relação às roças tradicionais. Muitas vezes, porém, a construção de dendrogramas apenas com as distàncias entre grupos sem a correção é adequada, como é o caso de avaliação do potencial de heterose entre linhagens e populações, as quais possuem diferentes niveis de diversidade, havendo, neste caso, um maior interesse justamente na distància entre os 
grupos. Foi utilizado o programa estatistico Statistica versão 5 para a construção deste dendrograma.

\subsection{Cálculo do índice de Shannon-Weaver para variáveis morfológicas e morfométricas}

A semelhança da diversidade isoenzimática expressa pelo índice de ShannonWeaver, um indice de Shannon-Weaver foi calculado para cada caráter morfológico em cada roça.

Para o cálculo destes indices e análises subseqüentes houve a necessidade de descartar alguns caracteres morfológicos. Foram descartados morfologia do lóbulo foliar (M5), pubescència das folhas jovens (M7) e proeminência das cicatrizes foliares (M17) porque não apresentaram variação, além do número de lóbulos da folha (M8) por apresentar variação numa mesma planta. Foram também descartadas as variáveis pedúnculo (M18) e cintas (M19), pois a diferença de idade das plantas dentro de uma mesma roça e entre roças não permitiu uma precisa avaliação destas variáveis. Descartouse ainda a variável cor da pelicula externa da raiz (M20), pois para avaliação precisa desta variável seria necessánio colher a planta e lavar a raiz, o que não foi possível.

Para o cálculo do indice de Shannon-Weaver destes dados fenotipicos foi necessána a transformação dos mesmos em variáveis binárias. A partir de variáveis multiestado não-ordendas referentes às variáveis fenotípicas como cor de folha, os individuos foram identificados atribuindo o valor 1 à classe que pertenciam e zero às outras classes, à semelhança do que foi feito com as isoenzimas. Uma variável como sinuosidade do limbo foliar teve seus dados transformados como na Tabela 10. 
Tabela 10- Exemplo de transformação de variáveis multiestado não-ordenadas para variáveis binárias

\begin{tabular}{|c|c|c|}
\hline Sinuosidade & \begin{tabular}{|l|} 
Multiestado \\
não-ordenado
\end{tabular} & Binária \\
\hline Lisa & 1 & 100 \\
\hline Intermediária & 2 & 010 \\
\hline Forte & 3 & 001 \\
\hline
\end{tabular}

O calculo do indice de Shannon-Weaver a partir destes dados é feito exatamente como o apresentado para dados de isoenzimas, porém ao invés de se raciocinar em termos de freqüência de bandas em uma população, deve-se pensar em freqüência de individuos da mesma classe fenotipica numa população. $O$ indice de Shannon-Weaver para este caso também foi normalizado em função do número de classes possiveis, dividindo-se o indice calculado pelo logaritmo do número de classes fenotípicas possiveis considerando todas as roças.

Ao invés de se trabalhar com as variáveis continuas de comprimentos e larguras optou-se por criar, a partir destas variáveis, variáveis que representassem mais a forma do que propriamente dimensão. Desta maneira $\mathrm{LM} / \mathrm{L}$ representa a razão entre comprimento do lóbulo médio e sua largura, $\mathrm{LD} / \mathrm{L}$ representa a razão entre largura do lóbulo a direita do lóbulo médio e a sua largura e $\mathrm{P} / \mathrm{F}$ representa a razão entre comprimento do peciolo e comprimento da folha. Esta decisão foi tomada pois é conhecido o fato de que a forma da folha da mandioca é controlada por poucos genes, o que torna possivel assumir que a forma da folha é capaz de discriminar diferentes clones melhor do que suas componentes separadamente. Obviamente, as variáveis originais não foram utilizadas, o que criaria uma forte redundância nas análises

A transformação de variáveis morfométricas continuas em variáveis binárias foi realizada atribuindo-se arbitrariamente classes a intervalos destas variáveis. O comprimento de peciolo, por exemplo, poderia ser dividido arbitrariamente em três classes, supondo que este varie de 5 a $15 \mathrm{~cm}$, como é observado na Tabela 11 . 
Tabela 11- Exemplo de transformação de variáveis multiestado ordenadas em variáveis binárias.

\begin{tabular}{|l|l|l|}
\hline Comprimento & $\begin{array}{l}\text { Multiestado } \\
\text { ordenado }\end{array}$ & binário \\
\hline $0-5 \mathrm{~cm}$ & 1 & 100 \\
\hline $5-10 \mathrm{~cm}$ & 2 & 110 \\
\hline $10-15 \mathrm{~cm}$ & 3 & 111 \\
\hline
\end{tabular}

À P/F, LM/L e LD/L foram atribuídas 9 classes diferentes, como é observado nas Tabelas 12 e 13 .

Tabela 12-Classes fenotípicas arbitránas para a variável $\mathrm{P} / \mathrm{F}$ e seus valores transformados para variáveis binárias.

\begin{tabular}{|l|l|l|l|l|l|l|l|l|l|}
\hline Classes & \multicolumn{7}{|l|}{ Dados transf. } \\
\hline $1,0-1,1$ & 1 & 0 & 0 & 0 & 0 & 0 & 0 & 0 & 0 \\
\hline $1,1-1,2$ & 1 & 1 & 0 & 0 & 0 & 0 & 0 & 0 & 0 \\
\hline $1,2-1,3$ & 1 & 1 & 1 & 0 & 0 & 0 & 0 & 0 & 0 \\
\hline $1,3-1,4$ & 1 & 1 & 1 & 1 & 0 & 0 & 0 & 0 & 0 \\
\hline $1,4-1,5$ & 1 & 1 & 1 & 1 & 1 & 0 & 0 & 0 & 0 \\
\hline $1,5-1,6$ & 1 & 1 & 1 & 1 & 1 & 1 & 0 & 0 & 0 \\
\hline $1,6-1,7$ & 1 & 1 & 1 & 1 & 1 & 1 & 1 & 0 & 0 \\
\hline $1,7-1,8$ & 1 & 1 & 1 & 1 & 1 & 1 & 1 & 1 & 0 \\
\hline $1,8-1,9$ & 1 & 1 & 1 & 1 & 1 & 1 & 1 & 1 & 1 \\
\hline
\end{tabular}

$\mathrm{O}$ ḿdice de Shannon-Weaver foi calculado da mesma maneira que anteriormente, utilizando apenas as classes que variavam na roça em questão, tendo sido também normalizado em função do número de classes possíveis considerando todas as roças, no caso, 9 classes. 
Tabela 13- Classes fenotipicas arbitrárias para as variáveis $L M / L$ e $L D / L$ e seus valores transformados para variáveis binárias.

\begin{tabular}{|l|l|l|l|l|l|l|l|l|l|}
\hline Classes & \multicolumn{10}{|c|}{ Dados } \\
\hline $1-2$ & 1 & 0 & 0 & 0 & 0 & 0 & 0 & 0 & 0 \\
\hline $2-3$ & 1 & 1 & 0 & 0 & 0 & 0 & 0 & 0 & 0 \\
\hline $3-4$ & 1 & 1 & 1 & 0 & 0 & 0 & 0 & 0 & 0 \\
\hline $4-5$ & 1 & 1 & 1 & 1 & 0 & 0 & 0 & 0 & 0 \\
\hline $5-6$ & 1 & 1 & 1 & 1 & 1 & 0 & 0 & 0 & 0 \\
\hline $6-7$ & 1 & 1 & 1 & 1 & 1 & 1 & 0 & 0 & 0 \\
\hline $7-8$ & 1 & 1 & 1 & 1 & 1 & 1 & 1 & 0 & 0 \\
\hline $8-9$ & 1 & 1 & 1 & 1 & 1 & 1 & 1 & 1 & 0 \\
\hline $9-$ & 1 & 1 & 1 & 1 & 1 & 1 & 1 & 1 & 1 \\
\hline
\end{tabular}

\subsection{Análise dos índices de Shannon-Weaver para isoenzimas e caracteres morfológicos}

Uma das perguntas que se quer responder neste trabalho é se houve uma alteração da diversidade genética nas roças de mandioca quando os agricultores deixaram de praticar a agricultura segundo o manejo tradicional e começaram a alterar este manejo. Outra questão é, assumindo que houve uma alteração da diversidade genética, poderia um processo seletivo associado a uma variável ambiental, no caso fertilidade do solo, ter contribuido para essa alteração?

Evidências que podem auxiliar a responder essas perguntas podem ser obtidas com a realização de um PCA envolvendo os índices de Shannon-Weaver para dados de isoenzimas e morfológicos. É importante lembrar que é possivel fazer inferências a respeito da diversidade genética das roças graças ao fato de que os caracteres morfológicos e isoenzimáticos estudados são pouco influenciados por variações ambientais.

Quanto ao processo seletivo, se a hipótese de que fertilidade do solo está contribuindo para alterar a diversidade genética estiver correta, o mínimo que se espera é 
encontrar uma certa correlação entre as variáveis de solo, que foram escolhidas por discriminar as rofas alteradas das tradicionais, e as variáveis que expressam diversidade, no caso, os indices de Shannon-Weaver para cada variável. Como são dados multivariados, uma análise de correlações canônicas seria adequada se não fosse o fato de que o número de roças em relação ao número de variáveis analisadas é muito pequeno, o que poderia comprometer a análise. O uso de um PCA com matriz de correlações envolvendo conjuntamente os dados referentes à fertilidade de solo e os indices de Shannon-Weaver foi a solução encontrada para, pelo menos, identificar uma associação entre fertilidade e diversidade genetica. Com a matriz de correlações foram construidos alguns graficos biplot, para que se possa identificar esta possivel associaçào. Análises de variància hierarquizadas por roça tambèm foram utilizadas para auxiliar a interpretação dos dados. O programa Fitopac versão 1.0 foi utilizado para a construção de todos os biplots.

Outro aspecto relevante que pode ser abordado com o cálculo dos indices de Shannon-Weaver è a distribuição da diversidade genètica entre e dentro de roças para cada caráter. Essa análise foi possivel fazendo a repartição da diversidade expressa pelo indice de Shannon-Weaver. Para isso, calcula-se para cada roça o indice de cada caráter. Calcula-se o mesmo indice conjuntamente para todas as roças, o que é uma forma de expressar a diversidade total. Isso é feito unindo-se as matrizes de presença e ausência de todas as rocas que entram na análise e calculando o indice de Shannon-Weaver normalmente. Obtem-se, a partir destes dados, a média das diversidades das roças $\left(\mathrm{H}_{\mathrm{o}}{ }^{\prime}\right)$ e a diversidade total $\left(\mathrm{H}_{\mathbf{t}}{ }^{\prime}\right)$ para cada caráter. A proporção da diversidade total devido à variação dentro de roças $\left(\mathrm{H}_{d}{ }^{\prime}\right)$ pode ser obtid a por:

$\mathrm{H}_{\mathrm{d}}{ }^{\prime}=\mathrm{H}_{0}{ }^{\prime} / \mathrm{H}_{\mathrm{t}}{ }^{\prime}$,

e a proporção da diversidade total devido à variação entre roças $\left(\mathrm{H}_{e}{ }^{\prime}\right)$ pode ser obtida por,

$\mathrm{H}_{\mathrm{e}}{ }^{\prime}=1-\mathrm{H}_{\mathrm{d}}{ }^{\prime}$. 


\subsection{Entrevista com os agricultores}

A utilização de correlações entre diversidade genética e variáveis ambientais pode ser considerada uma evidència de que um processo seletivo tenha ocorrido. Esse método é normalmente utilizado para superar a ausència de séries de dados no tempo, os quais seriam o tipo de dado ideal para identificar com certeza estes processos, pois seleção ocorre no decorrer do tempo. Estas correlações nada mais são do que uma "fotografia" da situação atual e corre-se, pois, o risco de se encontrar correlações sem nenhum significado biológico. A vantagem de estudar evolução em plantas cultivadas é o fato de que o que ocorreu num passado recente com relação a uma dada população de plantas cultivadas é fruto das ações dos agricultores e, conseqüentemente, deve fazer parte da memória dos mesmos. O depoimento dos agricultores é, portanto, muito valioso e deve ser considerado em conjunto com os dados obtidos experimentalmente na elaboração de um quadro mais completo do caso.

As entrevistas realizadas com os agricultores não foram feitas de forma estruturada, mas inseridas no decorrer de conversas informais. Não só os agricultores cujas roças foram estudadas foram questionados. Outros agricultores e ex-agricultores, da praia de Puruba, do sertão de Ubatumirim e da praia de Camburi também foram entrevistados. As questões foram direcionadas na tentativa de verificar algumas atitudes que pudessem ter conseqüèncias evolutivas, principalmente em relação à geração e manutenção de variabilidade genética na cultura da mandioca, além do caso especifico de seleção associada à fertilidade do solo.

Os principais pontos que foram enfocados nas entrevistas podem ser resumidos na seguinte lista:

- Quais etnovariedades (ramas) que plantam e se sempre plantaram estas etnovariedades.

- Quando plantam e quando colhem cada uma das etnovariedades.

- Como ocorre a "montagem" de uma roça e de onde vem as etnovariedades para esta atividade. 
- Para que servem as etnovariedades e se há diferenças fenotípicas entre as que são cultivadas com o mesmo objetivo.

- Se reconhecem plantas originárias de sementes, se identificam diferenças fenotipicas entre estas e as que possuem e o que fazem quando as encontram na roça.

- Se já presenciaram a germinação de mandiocas de sementes após a derrubada de capoeiras muito antigas.

- Se já batizaram alguma etnovariedade originada por semente.

- Porque plantam diferentes etnovariedades em mistura e se já plantaram alguma roça com apenas uma etnovariedade.

- Se plantam as mesmas etnovariedades em diferentes ambientes como áreas de morro, várzea e restinga e, se o fazem ou já fizeram, se reconhecem diferenças na performance da mesma etnovariedade em locais diferentes.

- Se reconhecem variação de performance em anos diferentes.

- O que fazem com o produto das roças.

- O que fazem quando recebem de um outro agricultor uma etnovariedade desconhecida.

- Se saporém e formiga cortadeira atacam etnovariedades diferencialmente e se estes ataques comprometem a produção de manivas para propagação.

- Se existe algum inimigo natural além de formiga e saporém.

- Como é organizada a fabricação de farinha.

Como os agricultores FA e FO fazem parte de uma situação específica, as entrevistas foram conduzidas na tentativa de resgatar a história destes dois agricultores, principalmente para ter uma idéia de como era a agricultura antes da implantação do parque, quais foram os impactos que mais afetaram o cultivo da mandioca e quais as atitudes que tomaram como reação a estes impactos. Procurou-se ainda, resgatar a memória destes agricultores com relação à diversidade que manejavam e comparar com a que manejam atualmente, baseando-se, è claro, na taxonomia local. 


\section{RESULTADOS E DISCUSSÃO}

\subsection{Roças e fertilidade do solo}

Com excessão de DFP, as roças escolhidas situam-se em locais declivosos nos contrafortes da Serra do Mar, sendo DFG e AG (tanto a roça AG amostrada para isoenzimas como para caracteres morfológicos) as mais declivosas e FA e FO medianamente declivosas. Os solos destas roças são rasos variando sua profundidade tanto entre as roças quanto numa mesma roça. A rocha muitas vezes aflora em matacões de gnaisse arredondados e proximo a estes afloramentos o solo atinge no máximo $20 \mathrm{~cm}$. Os solos das roças DFP e DFG são os mais rasos e as manivas eram plantadas mesmo entre matacões em solos de espessura de cerca de $10 \mathrm{~cm}$. Ambas as roças de AG possuiam solos com profundidades pouco maiores, sendo possivel observar, no entanto, áreas de solo bem raso e matacões. As roças FA e FO tinham os solos mais profundos mas mesmo assim pode-se observar matacões aflorando e áreas com solos rasos. A semelhança em termos de material de origem (rocha gnaissica), posição no relevo da região, clima e vegetação atuando sobre estes fatores são fortes evidências de que os solos destas roças devem também ser semelhantes quanto à sua gênese.

A julgar pelas informações da literatura citada e pelo que foi observado no campo, os solos destas roças devem variar entre solos litólicos, cambissolos álicos e latossolos vermelho-amarelo álicos, sendo possivel encontrar esta variação numa mesma roça.

As médias de cada variável da análise de solo por roça podem ser encontradas na Tabela 14 e o PCA referente a estas análises pode ser observado na Figura 2. Neste biplot, nota-se que o segundo eixo agrupa claramente as roças FA e FO, sendo que $\mathrm{P}$, 
$\% \mathrm{MO}, \mathrm{K}, \mathrm{H}+\mathrm{Al}$ (acidez potencial) e $\mathrm{T}$ (capacidade de troca de cátions) são as variaiveis que mais discriminam as roças FA e FO (alteradas) das demais (tradicionais). Tendo sido as roças FA e FO cultivadas continuamente com periodos de descanso curtos, è de se esperar, segundo a dinàmica da fertilidade do solo, que $\mathrm{P}$ pela fixação e erosão, $\mathrm{K}$ pela lixiviação, erosão e extração pela cultura e \%MO pela mineralização, sejam fatores que variem em relação àquelas roças que obedeceram ao manejo tradicional. A capacidade de troca de cátions $\mathrm{T}$ está muito correlacionada positivamente à \%MO. A acidez potencial $\mathrm{H}+\mathrm{Al}$ deve aumentar com $\mathrm{T}$, pois não variando o $\mathrm{pH}$, a disponibilidade de bases $(\mathrm{Ca}, \mathrm{Mg}$ e K) não é alterada. Como $\mathrm{T} \dot{e}$ formado pela soma de bases e $\mathrm{H}+\mathrm{Al}$, mantendo-se a concentração das bases constante, deve-se aumentar $\mathrm{H}+\mathrm{Al}$ se $\mathrm{T}$ aumenta. As diferenças entre as roças alteradas e tradicionais em termos de fertilidade do solo estão, portanto, coerentes com a dinâmica inerente ao sistema de agricultura tropical autóctone encontrado na literatura.

Comparando as roças FA e FO com as roças DFG, DFP e AG, o biplot da Figura 2 tambem revela uma evidente homogeneidade das primeiras em termos de fertilidade do solo em comparação com as últimas. Quando um agricultor derruba a vegetação e a queima, a matéria orgànica e as cinzas tendem a se concentrar em certos locais, causando esta heterogeneidade na fertilidade do solo em roças tradicionais. Por outro lado, o processo de empobrecimento do solo parece ser mais rápido nos locais onde o solo é mais fërtil, provocando uma uniformidade da fertilidade do solo em niveis baixos quando as roças são exploradas continuamente. Portanto, se por um lado as roças FA e FO tem solos uniformemente pobres, os solos das demais roças formam um mosaico em relaçào à fertilidade. 
Tabela 14- Médias das variáveis de solo analisadas para cada roça.

\begin{tabular}{|l|l|l|c|c|c|c|c|c|c|c|}
\hline Roça & $\mathrm{P}$ & $\% \mathrm{MO}$ & $\mathrm{pH}$ & $\mathrm{K}$ & $\mathrm{Ca}$ & $\mathrm{Mg}$ & $\mathrm{H}+\mathrm{Al}$ & $\mathrm{S}$ & $\mathrm{T}$ & $\mathrm{V} \%$ \\
\hline DFG & 19,80 & 6,24 & 4,05 & 0,12 & 0,89 & 0,31 & 12,74 & 1,32 & 14,07 & 9,67 \\
\hline AG & 9,30 & 5,21 & 3,96 & 0,07 & 0,86 & 0,14 & 12,41 & 1,09 & 13,49 & 8,64 \\
\hline FO & 5,18 & 3,53 & 3,83 & 0,04 & 0,16 & 0,05 & 9,98 & 0,27 & 10,22 & 2,50 \\
\hline DFP & 13,39 & 4,53 & 3,88 & 0,09 & 0,67 & 0,22 & 11,76 & 1,01 & 12,77 & 8,74 \\
\hline FA & 5,86 & 4,14 & 3,9 & 0,04 & 0,26 & 0,10 & 9,63 & 0,41 & 10,04 & 4,21 \\
\hline
\end{tabular}

Figura 2- Biplot referente ao PCA das análises de solo de todas as roças.

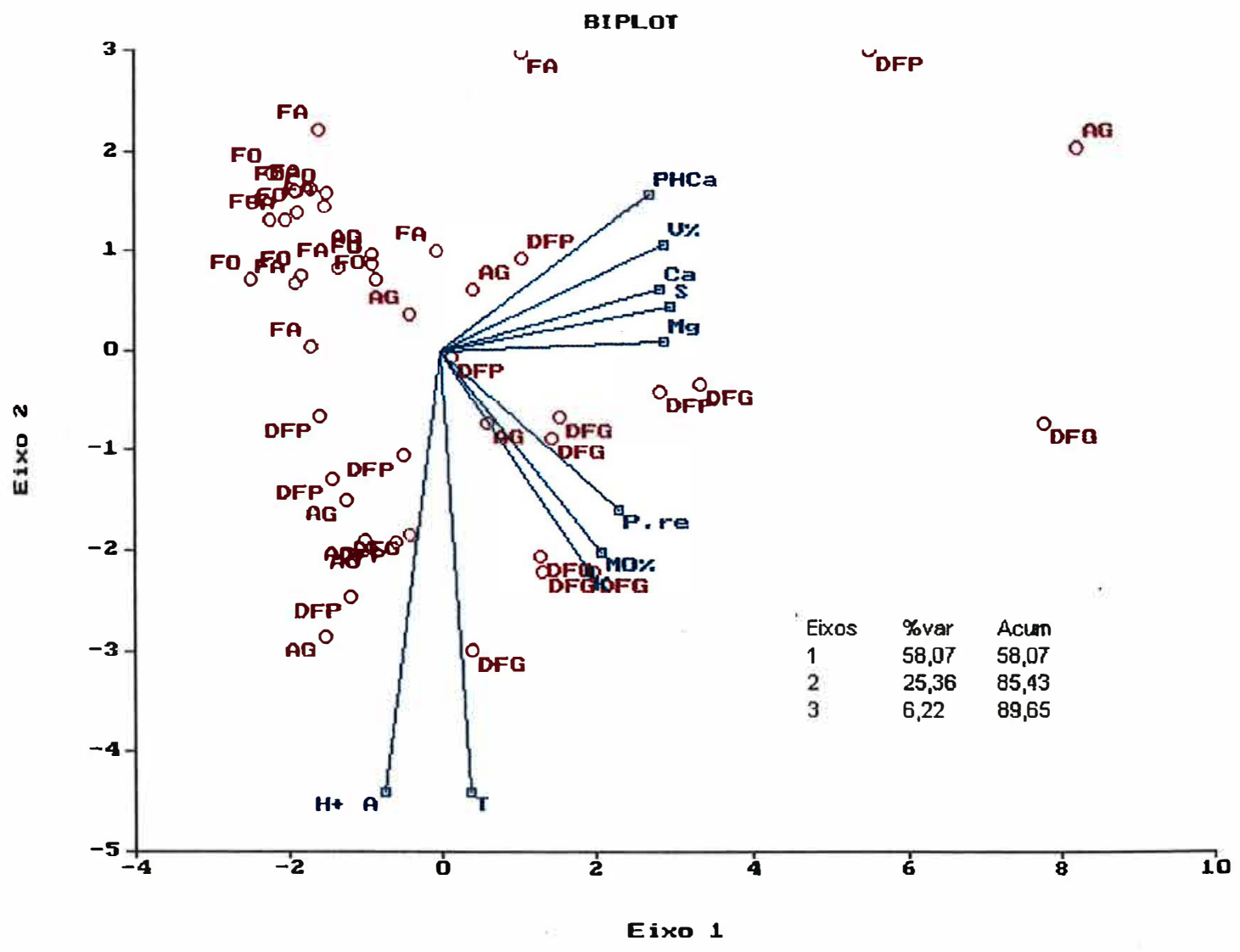

Os resultados das análises de variância para $\mathrm{P}$ transformado em arcsen $\sqrt{\mathrm{P}}$, \%MO transformada para arcsen $\sqrt{ } \% \mathrm{MO}$ e $\mathrm{K}$ transformado para $\sqrt{\mathrm{K}}$ podem ser observadas nas 
Tabelas 15, 16 e 17. Em todas as análises, pode-se constatar a existência de diferenças significativas entre roças. Foram eliminados dois "outliers" em arcsen $\sqrt{P}$ na roça DFG e dois em arcsen $\downarrow \% \mathrm{MO}$ da roça $\mathrm{AG}$ para que fosse respeitado pressuposto de normalidade dos dados na anàlise. Diferenças significativas entre roças puderam também ser observadas em arcsen $\sqrt{ } \mathrm{V} \%$ e $\sqrt{ } \mathrm{T}$. O pH não mostrou diferenças significativas entre roças. Os dados de $\mathrm{H}+\mathrm{Al}$ transformados em arcsen $\sqrt{ } \mathrm{H}+\mathrm{Al}$, mostraram diferenças significativas, porém, mesmo com a transformação, o pressuposto de homogeneidade de variàncias para realização da análise para esta variável não foi alcançado, o que pode levantar dúvidas quanto à análise de variància. Observando o PCA conjuntamente com a análise de variància é possivel supor que as diferenças para este fator sejam fato significativas.

Tabela 15- Análise de variância para arcsen $\sqrt{ } \mathrm{P}$

\begin{tabular}{lllll}
\hline Fonte de var. & SQ & GL & QM & F \\
\hline Roças & 0,2301 & 4 & 0,0575 & $30,0^{* *}$ \\
Erro & 0,7312 & 38 & 0,0019 & \\
\hline
\end{tabular}

Tabela 16- Analise de variância para arcsen $\sqrt{ } \% \mathrm{MO}$.

\begin{tabular}{lllll}
\hline Fonte de var. & SQ & GL & QM & F \\
\hline Roças & 0,0221 & 4 & 0,0055 & $27,5^{* *}$ \\
Erro & 0,0072 & 38 & 0,0002 & \\
\hline
\end{tabular}

Tabela 17- Análise de variância para $\sqrt{K}$

\begin{tabular}{lcccc}
\hline Fonte de var. & SQ & GL & QM & F \\
\hline Roças & 0,1573 & 4 & 0,0393 & $28,44^{* *}$ \\
Erro & 0,0553 & 40 & 0,001 & \\
\hline
\end{tabular}


Para se ter uma melhor ideia da fertilidade destes solos pode-se observar nas Tabelas 18 e 19 a classificação de algumas variáveis encontradas na análise de solo segundo o Boletim 100 do Insututo Agronòmico de São Paulo (Raij et al., 1996).

Tabela 18- Classificação dos teores de fósforo $(\mathrm{P})$ e potássio $(\mathrm{K})$ e valores de $\mathrm{pH}$ e saturação de bases (V\%) em solos segundo o Boletim 100 do Instituto Agronòmico de São Paulo (Raij et al., 1996).

\begin{tabular}{|l|c|c|c|c|}
\hline Classes & $\mathrm{P}(\mathrm{ppm})$ & $\mathrm{K}(\mathrm{meq} / 100 \mathrm{~g})$ & $\mathrm{pH}$ & $\mathrm{V} \%$ \\
\hline Muito baixo & $0-6$ & $0-0,7$ & até 4,3 & $0-25$ \\
\hline Baixo & $7-15$ & $0,8-1,5$ & $4,4-5,0$ & $26-50$ \\
\hline Médio & $16-40$ & $1,6-3,0$ & $5,1-5,5$ & $51-70$ \\
\hline Alto & $41-80$ & $3,1-6,0$ & $5,6-6,0$ & $71-90$ \\
\hline Muito alto & $>80$ & $>6,0$ & $>6,0$ & $>90$ \\
\hline
\end{tabular}

Tabela 19- Classificação dos teores de cálcio e magnésio em solos segundo o Boletim 100 do Instituto Agronômico de São Paulo (Raij et al., 1996).

\begin{tabular}{|l|l|l|}
\hline Classes & $\mathrm{Ca}(\mathrm{meq} / 100 \mathrm{~g})$ & $\mathrm{Mg}(\mathrm{meq} / 100 \mathrm{~g})$ \\
\hline Baixo & $0-3$ & $0-4$ \\
\hline Médio & $4-7$ & $5-8$ \\
\hline Alto & $>7$ & $>8$ \\
\hline
\end{tabular}

\subsection{Isoenzimas}

Nos sistemas isoenzimáticos utilizados, foram encontradas 8 bandas no sistema $\mathrm{MDH}$, das quais 4 são polimórficas; 4 bandas no sistema LAP, das quais 2 são polimórficas; 7 no sistema PGI, das quais 4 são polimórficas e 5 bandas, todas polimórficas, no sistema SKDH. O padrão obtido com estas bandas foi bem coerente com 
o obtido por Lefevre \& Charrier (1993b) e Peroni ${ }^{8}$ e pode ser observado nos zimogramas da Figura 3, os quais representam as distâncias de cada banda com relação à linha de frente da corrida expressas pelo valor RF (Alfenas et al., 1991).

Figura 3- Zimogramas contendo os fenótipos encontrados em todos os sistemas utilizados e comparados com a linha de frente de migração na posição 1,0 .

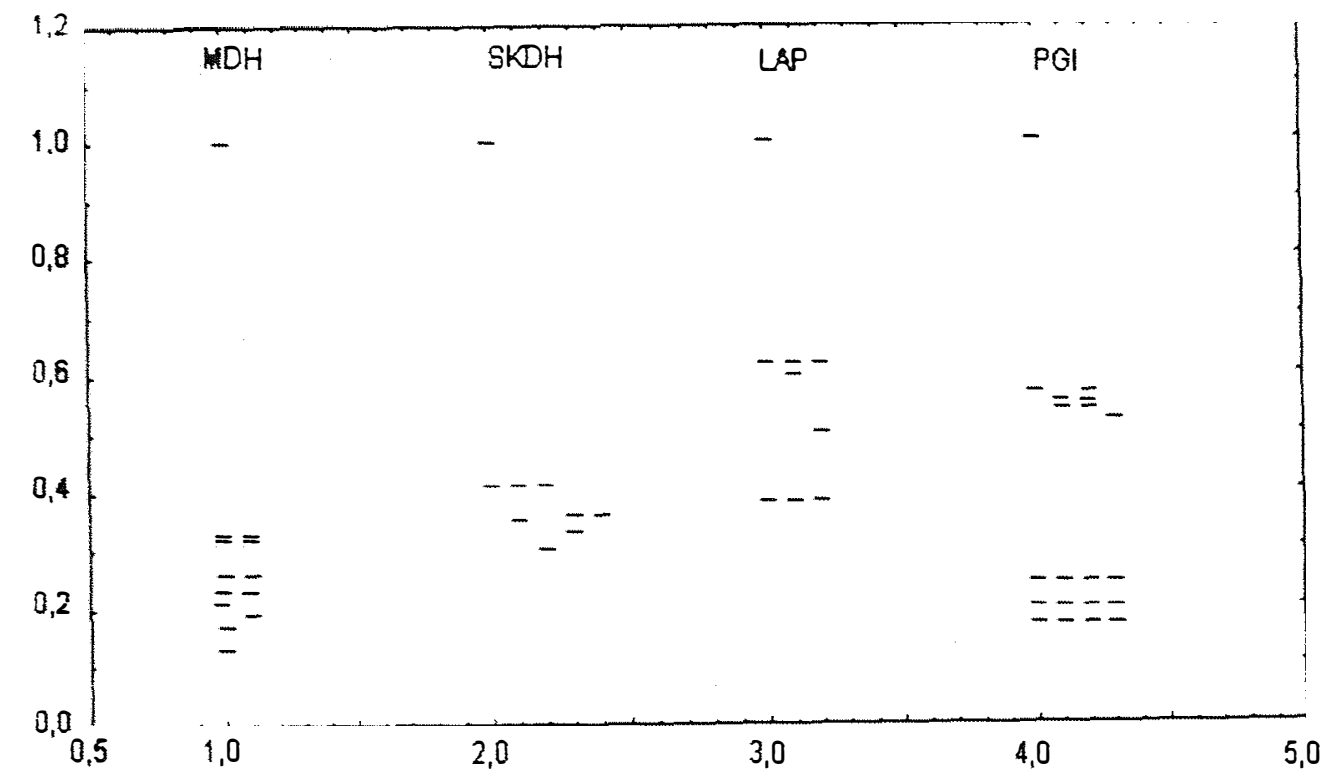

${ }^{8}$ Pcroni. N. Taxonomia "folk" c divcrsidade intra-cspecifica de mandioca (Manihot esculenta Crantz) em roças de agricultura tradicional em áreas de Mata Atlântica do sul do Estado de São Paulo. Piracicaba, no prelo. 191p. Dissertação (Mestrado). Escola Superior de Agricultura "Luiz de Queiroz", Universidade de São Paulo. 


\subsection{Comparação da diversidade fenotípica obtida por isoenzimas e a diversidade reconhecida pelo agricultor}

$\mathrm{Na}$ amostragem para realização de isoenzimas, 12 etnovariedades foram identificadas pelo agricultor DF em 62 plantas amostradas, as quais estão relacionadas na Tabela 20 com suas respectivas freqüências na amostra e suas abreviações. Alguns individuos não foram identificados e receberam a abreviação NI. Não se observa o predominio de uma etnovariedade sobre as outras na roça DFG.

Tabela 20- Etnovariedades coletadas na roça DFG, suas freqüèncias na amostra de 62 indivíduos e suas abreviações.

\begin{tabular}{|l|c|l|c|}
\hline Etnovariedade & $\begin{array}{c}\text { Freqüência na } \\
\text { amostra (\%) }\end{array}$ & Etnovariedade & $\begin{array}{c}\text { Freqüência na } \\
\text { amostra (\%) }\end{array}$ \\
\hline Landí-Preto (LP) & 9,7 & Mucaé-Roxo (MR) & 1,6 \\
\hline Paranaense (P) & 17,7 & Landí-Bravo (LB) & 3,2 \\
\hline Carioca (C) & 9,7 & Mucaé-Ferro (MF) & 1,6 \\
\hline Campista (CA) & 19,3 & Landí-Ferro (LF) & 1,6 \\
\hline Roxinha (RO) & 4,8 & Mucaé-Bravo (MB) & 1,6 \\
\hline Maricá (M) & 17,7 & Rama-Branca (RB) & 1,6 \\
\hline & & Não identif. (NI) & 8,1 \\
\hline
\end{tabular}

No dendrograma da Figura 4 observam-se os fenótipos obtidos por isoenzimas a partir de 62 individuos. Apenas 9 fenótipos diferentes foram discriminados com os sistemas isoenzimáticos utilizados. Isso é uma discrepância em relação ao que se pode verificar na literatura, em que normalmente se observa uma maior diversidade isoenzimática em relação a diversidade reconhecida pelo agricultor. O fato dos sistemas utilizados não terem sido capazes de diferenciar as etnovariedades Campista e Maricá, 
Carioca e Mucae-Ferro, Paranaense e Rama-Branca e Rovinha e Landi-Ferro foi determinante neste resultado.

Nota-se que este agricuitor tem uma coerència no seu sistema de classificação pois, embora os sistemas não tenham sido muito eficientes em diferenciar certas etnovariedades, etnovariedades pertencentes a uma classe fenotípica tendem a não aparecer em outra classe, o que fica evidente com as etnovariedades Carioca, Campista, Maricá, Roxinha e Paranaense. Por outro lado, as etnovariedades que tem Landi ou Mucae no nome tendem a formar grupos de fenótipos semelhantes, ao contrário das citadas anteriormente que são representadas por um fenótipo único. Para melhor entender os possiveis motivos deste fenòmeno, è necessário fazer algumas considerações a respeito destas etnovariedades. Quando os agricultores foram questionados a respeito das etnovariedades que conheciam, todos, inclusive outros cujas roças nào foram estudadas e mesmo alguns ex-agricultores, conheciam os nomes Landi e Mucaé, porém os nomes Carioca, Campista e Paranaense eram conhecidos apenas pelo agricultor DF. Isto sugere que as primeiras sejam etnovariedades bem antigas e disseminadas na regiào, enquanto as outras recentemente introduzidas. Schmidt (1958) cita os nomes Landi e Mucaé, o que fortalece a afirmação de que estas sejam etnovariedades antigas na região. Segundo o modelo de domesticaçào proposto por Martins modificado de Cury (1993) e discutido no item 2.9, existe a possibilidade de recombinação inter e intra-especifica através de plantas originárias de sementes que germinam espontaneamente na roça e são incorporadas pelos agricultores consciente ou inconscientemente. A maioria dos agricultores reconhece plantas originánas de sementes pelo fato destas possuírem raiz pivotante. Neste caso, pode-se esperar que uma etnovariedade seja constituída por um grupo de genótipos a medida que novos recombinantes vão surgindo e vão sendo classificados com o mesmo nome que as etnovariedades pré-existentes. Uma nova etnovariedade pode eventualmente ser batizada com outro nome, caso as diferenças fenotípicas forem observáveis pelo agricultor a ponto deste discriminá-la como uma nova etnovariedade. Sendo as etnovariedades Landí e Mucaé mais antigas, este processo teve muito mais tempo de acontecer do que etnovariedades recentemente introduzidas, o que é evidenciado pelo 
fato de existir mais de um nivel taxonòmico no caso de Landi e Mucaé (Landi-Ferro, por exemplo) e apenas um nivel no caso de Campista, Maricá, Carioca e Paranaense.

Há pelo menos duas hipóteses para explicar a uniformidade genètica dentro das etnovariedades tidas como recentemente introduzidas. Elas podem ter feito parte de um conjunto de genótipos agrupados com nomes Carioca, Campista etc., que quando introduzidas sofreram um efeito de gargalo, o qual reduziu seu tamanho efetivo e, portanto, podem estar sendo representadas por apenas um genótipo. Há, entretanto, a possibilidade destas etnovariedades serem clones melhorados que por definição são constituidos por apenas um genótipo. Em ambos os casos, não houve tempo para o aparecimento de recombinantes que ampliariam a diversidade genética destas etnovariedades, jà que foram recentemente introduzidas. Infelizmente não foi possivel confirmar estas hipóteses com base nos dados ou nas entrevistas com os agricultores.

$\dot{E}$ interessante notar que indivíduos apontados com sendo pertencentes à etnovariedade Landi-Preta estão bem agrupados. Landi-Brava e Mucaé-Brava formam também um grupo bem definido o que sugere que o fato de serem bravas, seja lá o que isto significa em termos de taxonomia local, è mais importante do que o fato de serem Landi ou Mucaé. Mucaé-Ferro e Mucaé-Roxa também formam um grupo separado e bem definido. É dificil dizer se o indivíduo com mesmo fenótipo que a Mucaé-Roxa identificado como Paranaense foi ou não um erro de identificação, assim como o individuo identificado como Landi-Preto no grupo da Maricá e Campista.

A etnovariedade Mucaé-Roxa é um caso descrito pelo agricultor DF como uma etnovariedade originada por uma planta de semente. Um antigo agricultor do Puruba, observando uma planta proveniente de germinação de semente identificou-a como sendo Mucaé, mas notou diferenças suficientes para batizá-la como Mucaé-Roxa. Estas diferenças foram tambèm suficientes para que outros agricultores como o agricultor DF adotassem o nome.

O agricultor DF $\dot{e}$ muito observador em relação às diferenças entre as etnovariedades e diz reconhecer diferenças fenotípicas em plantas originárias de semente, tendo tambejm comentado que certa vez ao encontrar uma destas plantas, pode identificar 
a etnovariedade a que pertencia, estranhando, contudo, o fato de que a coloração da raiz diferia daquela que costumeiramente observava na referida etnovariedade. Aparentemente, apesar de reconhecer diversidade em mandioca, ele não associa o fato de existir plantas originadas de sementes com reprodução sexual e geração de diversidade, como è comum ser reconhecido por quem cultiva milho, planta exclusivamente sexual e predominantemente alógama.

Figura 4- Dendrograma contendo as plantas amostradas na roça DFG construido com dados de isoenzimas. Coeficiente de correlação cofenética $=0,94$

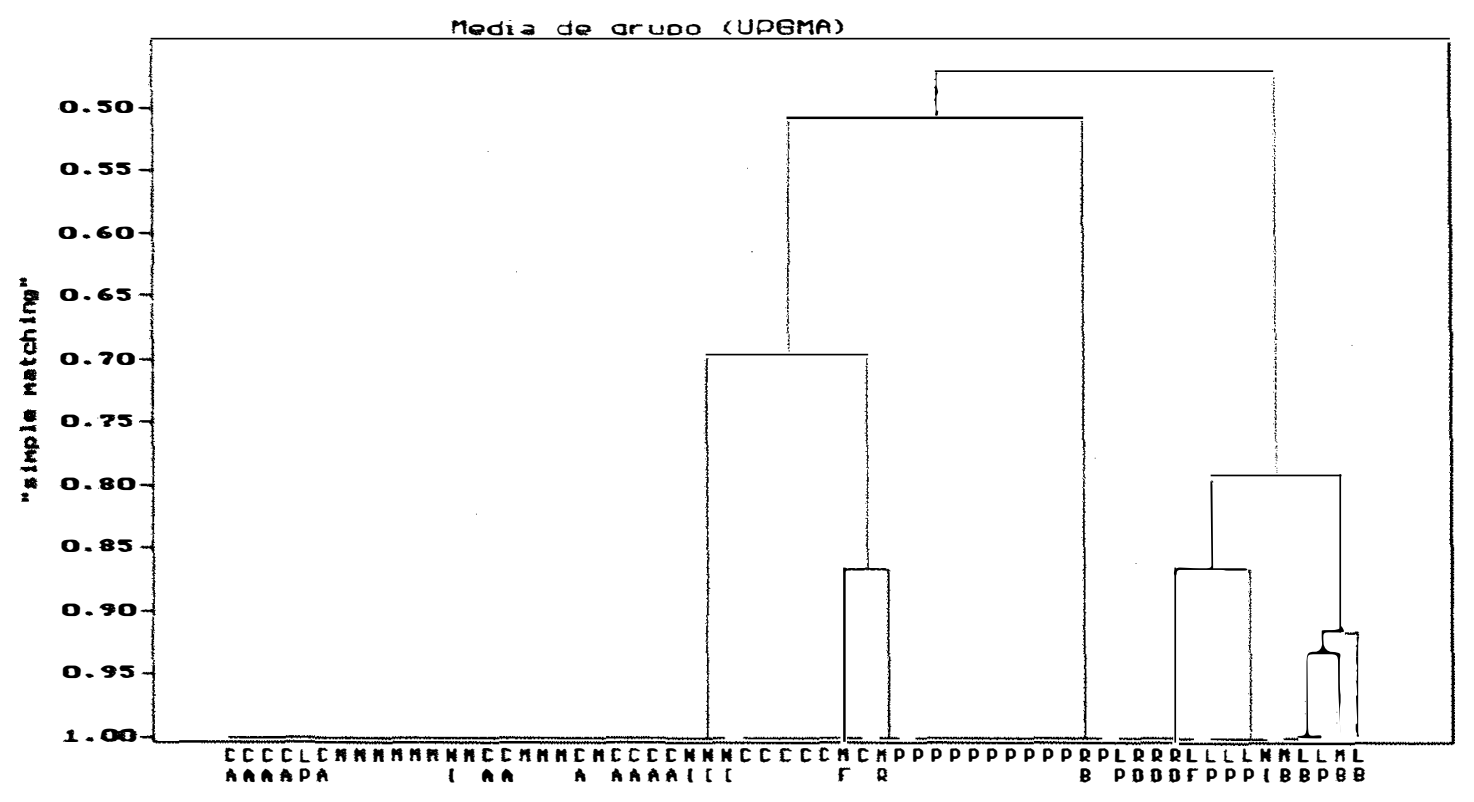

O agricultor AG identificou 8 etnovariedades listadas na Tabela 21, com suas freqüèncias na amostra e suas respectivas abreviações. Pode-se observar no dendrograma da Figura 5 que 10 fenótipos diferentes foram discriminados com os sistemas utilizados a partir de 52 individuos. Aqui, a diversidade reconhecida pelo agricultor subestima a diversidade obtida através de isoenzimas e, apesar de ter sido coletado maior número da etnovariedade Dois-Irmãos em relação às outras, não se pode dizer que há um predominio de uma etnovariedade. 
Tabela 21- Etnovariedades coletadas na roça AG, suas proporções na amostra de 52 individuos e suas abreviações.

\begin{tabular}{|l|c|l|c|}
\hline Etnovariedade & $\begin{array}{c}\text { Freqüència na amostra } \\
(\%)\end{array}$ & Etnovariedade & $\begin{array}{c}\text { Freqüência na amostra } \\
(\%)\end{array}$ \\
\hline Amarelinha (AM) & 13,4 & Mata-Fome (MT) & 5,8 \\
\hline Dois-Irmãos (2I) & 38,4 & Mandioca-Doce(MD) & 1,9 \\
\hline Landi (LA) & 11,5 & Landizinho (LD) & 1,9 \\
\hline Aipi-Rosa (AR) & 17,3 & Rama-Preta (RP) & 9,6 \\
\hline
\end{tabular}

Figura 5- Dendrograma contendo as plantas amostradas na roça AG construido com dados de isoenzimas. Coeficiente de correlação cofenética $=0,88$

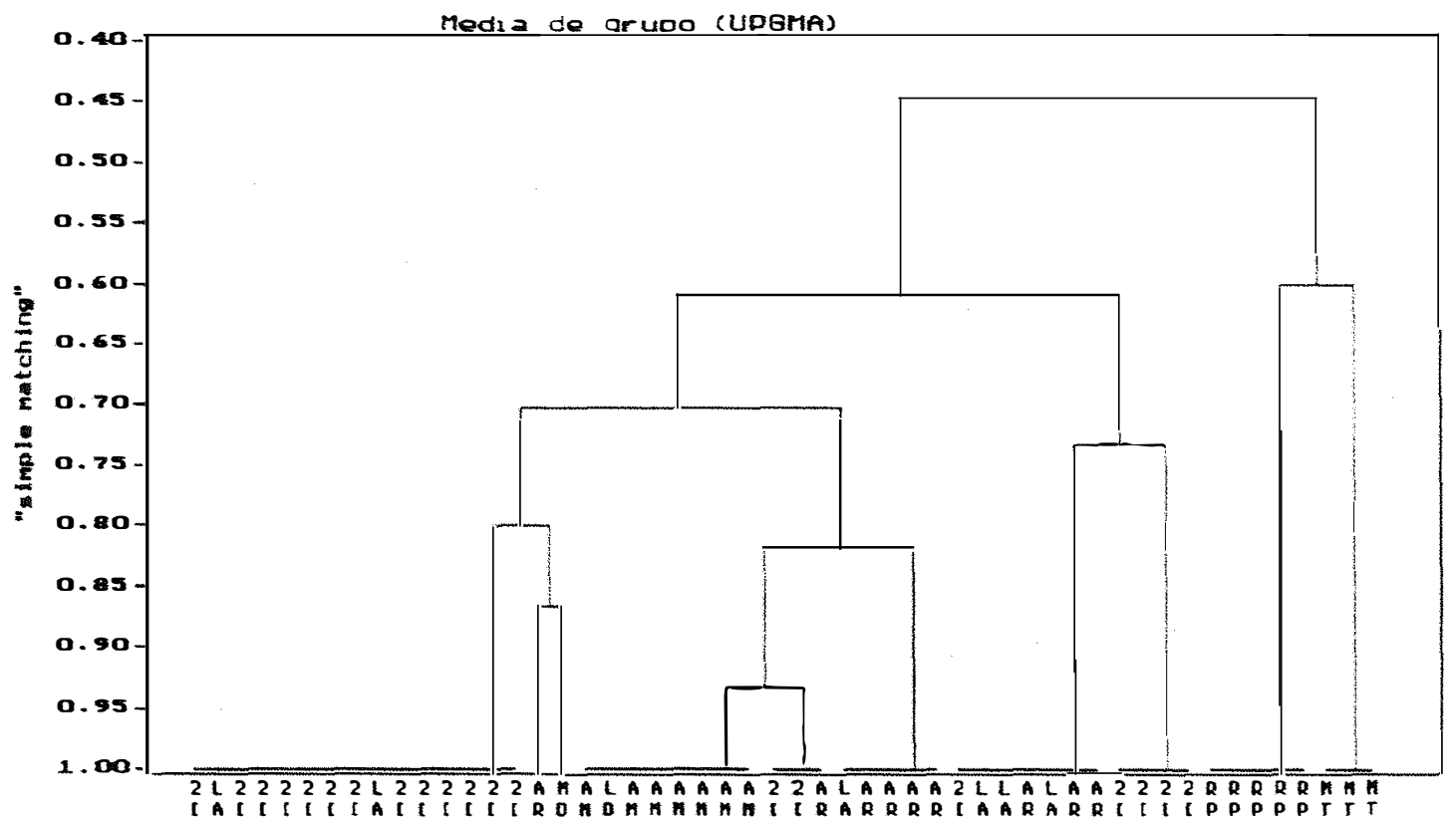

Nota-se que o agricultor também possui certa coerência na sua classificação, porém a acurácia com que diferencia uma etnovariedade da outra não é muito boa. Há alguns individuos que nitidamente parecem ter sido identificados com nomes trocados. A maior 
confusão se dá entre Landi, Aipi-Rosa e Dois-Irmãos, as quais aparecem eventualmente em grupos bem diferentes. Houve a possibilidade de questionar o agricultor a respeito da facilidade ou dificuldade com que identifica diferentes etnovariedades. Este confirmou que sentia muitas vezes insegurança na identificação de algumas etnovariedades especificas, o que reforça a idéia de que comete equívocos na identificação.

É interessante observar que há algumas etnovariedades como a Mata-Fome, Amarelinha e a Rama-Preta que ele identifica sem muito problema. A Rama-Preta, por exemplo, possui um peciolo bem escuro o que facilita sua identificação. Este è um bom exemplo de um caráter puramente perceptivo utilizado como marcador de um genótipo especifico, concordando com as conclusões de Boster (1985).

A etnovariedade Dois-Irmãos é encontrada em 4 grupos bem distintos sendo que pelo menos dois deles possuem praticamente apenas indivíduos identificados como DoisIrmãos. Este caso parece estar também associado à dificuldade do agricultor AG em discriminar duas etnovariedades diferentes. Embora não seja possível conjecturar quão diferentes fenotipicamente são estes grupos com os dados que se dispõe, é provável que nas mãos de uma agricultor mais atento a detalhes, estes dois grupos teriam nomes diferentes.

Uma forte evidència de que este agricultor não tem muita capacidade de discriminação é o fato de que apesar de reconhecer plantas provenientes de sementes, quando inquirido se jả observou diferenças fenotípicas destas plantas em relação às que possuia, dizia que não, que eram as mesmas. Se estas plantas originadas de sementes são derivadas de cruzamentos, é muito provável que existam diferenças fenotípicas observáveis, principalmente nos caracteres perceptivos e, portanto, a percepção destas diferenças é uma evidència da capacidade de observação do agricultor, como demonstrou o agricultor DF. Alèm disso, comparado com o agricultor DF, o agricultor AG só reconhece um tipo de Landí, enquanto o primeiro reconhece Landí-Preta, Landí-Brava e Landi-Ferro, sugerindo que o primeiro é capaz de diferenciar etnovariedades com um nível taxonòmico a mais, ou seja, com maior nível de detalhe. Torna-se dificil, no caso de AG, avaliar o que realmente é diversidade fenotípica dentro de etnovariedades, o que é 
equívoco de identificação e o que é incapacidade de discriminar etnovariedades diferentes.

Âs amostras da roça DFP não puderam ser identificadas pelo agricultor. Portanto, apenas o número de fenótipos obtidos com isoenzimas pode ser extraido desta roça. Nove fenótipos diferentes foram identificados no dendrograma da Figura 6 com dados de isoenzimas a partir de 35 individuos. Não se observa o predomínio de um fenótipo em relação aos outros.

Figura 6 - Dendrograma contendo as plantas amostradas na roça DFP construído com dados de isoenzimas. Coeficiente de correlação cofenética $=0,91$

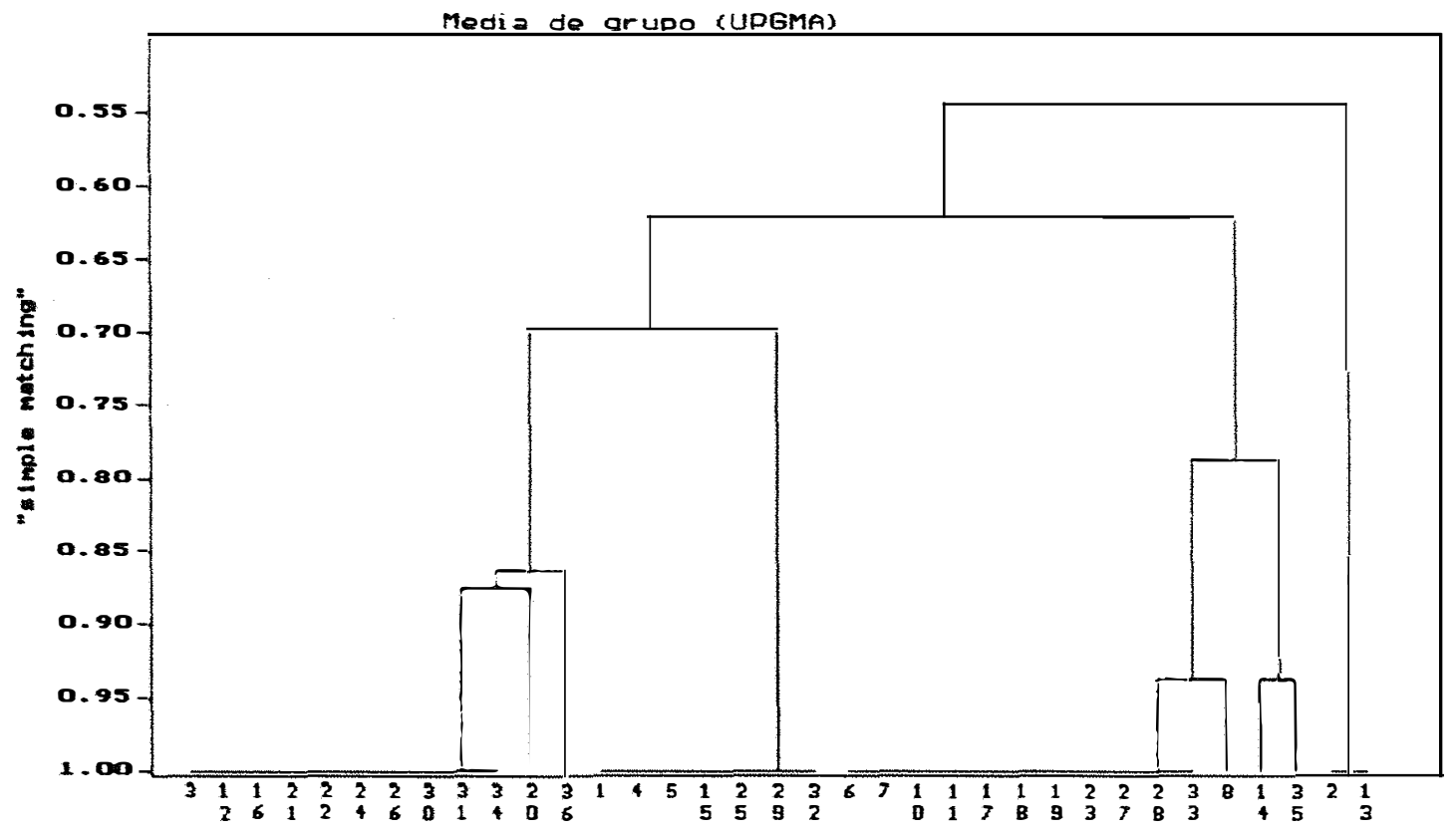

O agricultor FA reconhece 4 etnovariedades em 45 individuos amostrados, como é observado na Tabela 22. Cinco fenótipos foram discriminados com os sistemas utilizados a partir de 39 individuos (apesar de terem sido coletados 45), como é observado no dendrograma da Figura 7. A diferença ocorreu porque alguns individuos tinham seus dados isoenzimáticos incompletos e foram descartados para a construção do dendrograma. Neste caso, a diversidade obtida por isoenzimas foi maior do que aquela 
reconhecida pelo agricultor e, ao contrário das roças anteriores, uma etnovariedade, a etnovariedade Marica, predomina em relação às outras.

Tabela 22- Etnovariedades coletadas na roça FA, suas freqüências na amostra de 45 individuos e suas abreviações.

\begin{tabular}{|l|c|}
\hline Etnovariedades & Freqüência na amostra (\%) \\
\hline Aipi-Preta (AP) & 2,2 \\
\hline Marica (M) & 82,2 \\
\hline Rosinha (R) & 13,3 \\
\hline Zumira (Z) & 4,4 \\
\hline
\end{tabular}

Figura 7- Dendrograma contendo as plantas amostradas na roça FA construido com dados de isoenzimas. Coeficiente de correlação cofenética $=0,97$

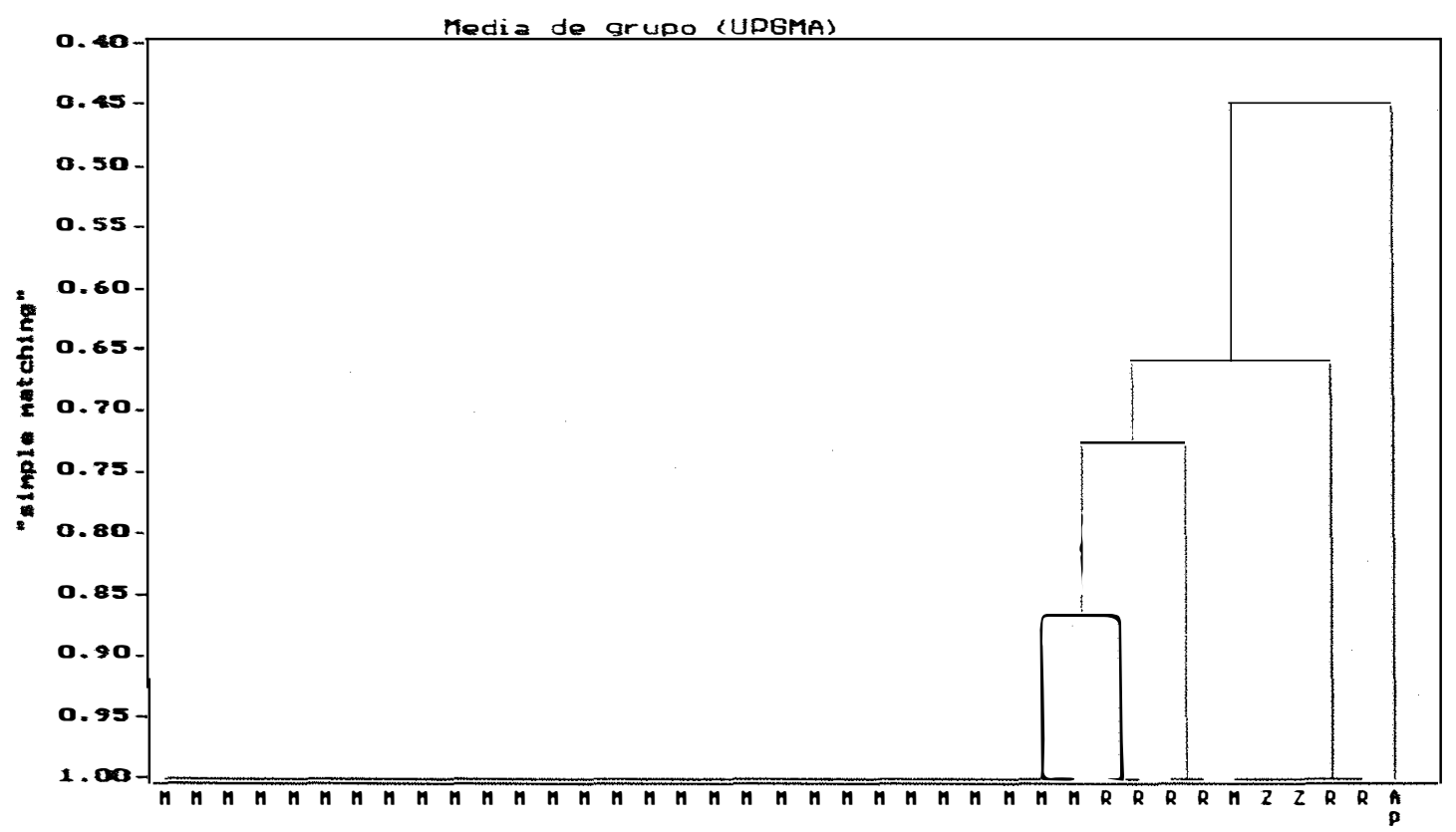

O agricultor FA agrupa a etnovariedade Maricá num único grupo com excessão de um individuo que pode muito bem ser resultado de equivoco na classificação. A 
etnovariedade Rosinha não é constituida de um único fenótipo e sim de um grupo de fenótipos com relativa proximidade. As outras etnovariedades, Zumira e Aipi-Preto são representadas por um único fenótipo cada. A etnovariedade Zumira é agrupada junto com alguns individuos da Rosinha e um individuo Maricá. É possivel que o agricultor FA tenha dificuldade de separar Rosinha de Zumira.

$\mathrm{O}$ agricuitor FO reconhece 5 etnovariedades diferentes em 34 individuos, como pode ser observado na Tabela $23 \mathrm{com}$ as respectivas freqüèncias na amostra e abreviaçōes. Como pode ser observado no dendrograma da Figura 8, foram discriminados 8 fenótipos diferentes a partir de 34 indivíduos. À semelhança do que ocorre na roça FA, a etnovariedade Maricá predomina nesta roça e é bem discriminada pela classificaçào do agricultor, apesar de verificar-se a presença de individuos classificados como Maricá em outros grupos.

Tabela 23- Etnovariedades coletadas na roça FO, suas freqüèncias na amostra de 34 indivíduos e suas abreviações.

\begin{tabular}{|l|c|}
\hline Etnovariedades & Freqüência na amostra (\%) \\
\hline Marica (M) & 79,4 \\
\hline Roxinha (RO) & 5,9 \\
\hline Santa Helena (SH) & 2,9 \\
\hline Zumira (Z) & 8,8 \\
\hline Dois-Irmãos (2I) & 2,9 \\
\hline
\end{tabular}


Figura 8- Dendrograma contendo as plantas amostradas na roça FO construido com dados de isoenzimas. Coeficiente de correlação cofenética $=0,99$

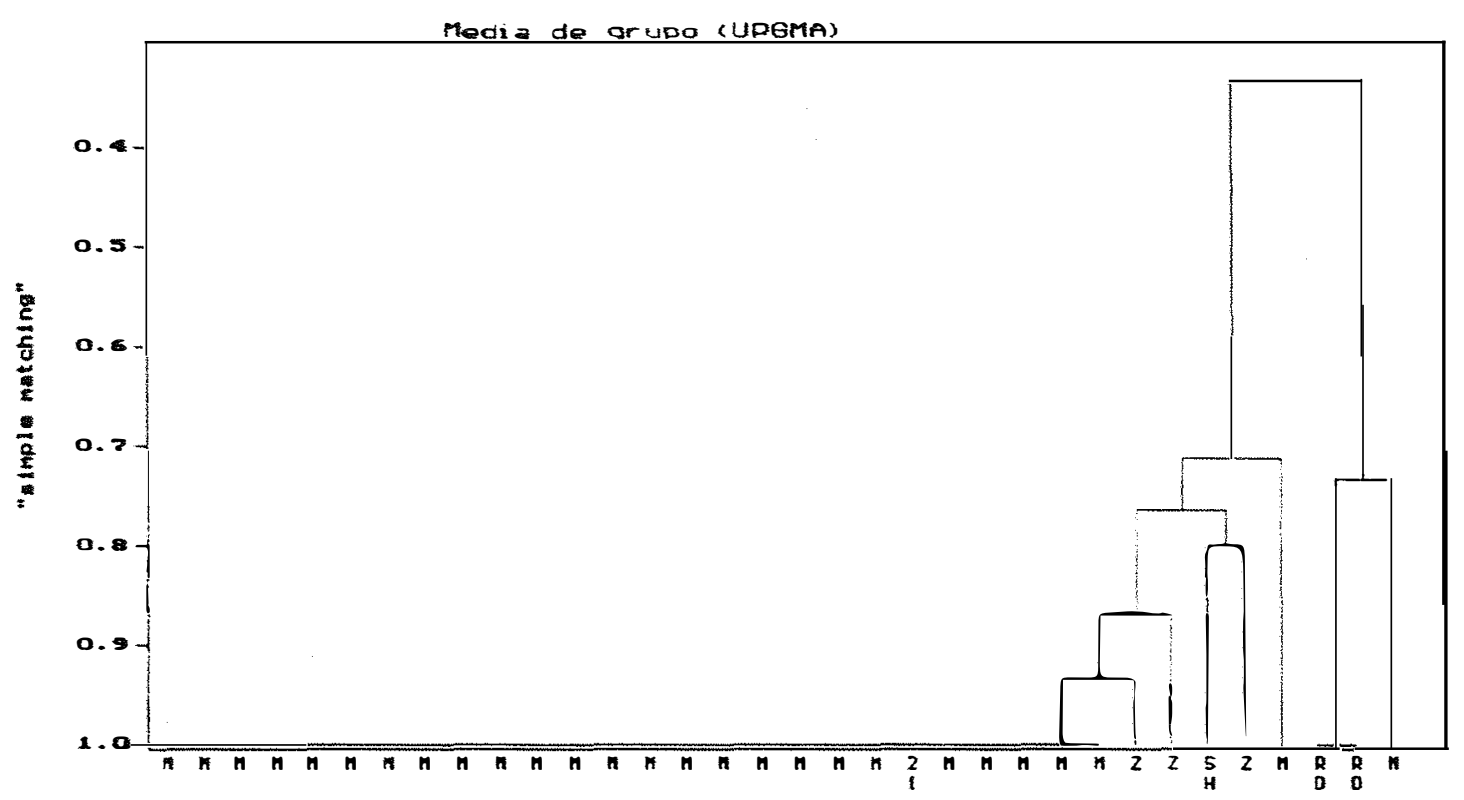

Nesta roça, a etnovariedade Zumira é constituída por um grupo de fenótipos com relativa similaridade isoenzimatica. A etnovariedade Roxinha, bem característica pelas folhas e ramos novos roxos, é representada por apenas um fenótipo. É interessante comparar o caso da etnovariedade Rosinha da roça FA, a qual tem a característica de ter seus ramos novos roseados, e Roxinha da roça FO. Apesar de não ter-se aprofundado na questão, ambas parecem ter sido batizadas em função de um caráter perceptivo, cor de ramificação jovem e folhas jovens, porém, enquanto a primeira é composta por vários fenótipos isoenzimáticos, a segunda é representada apenas por um fenótipo. Pode-se tirar algumas lições deste fato à luz do artigo de Boster (1985), a despeito destas etnovariedades terem sido pouco representadas.

Utilizar caracteres perceptivos como uma forma de marcador, fazendo inferências à respeito de caracteres adaptativos em função dos primeiros, só é possível graças à propagação clonal, a qual, pelo fato de impedir a recombinação, faz do clone um grande grupo de ligação. É como se estes agricultores fizessem um tipo de seleção assistida por marcadores. Em contrapartida, eventuais recombinações permitem que haja uma certa 
independència dos genes. De fato, usar marcadores para seleção de caracteres quantitativos é uma grande vantagem, porém, com relação àqueles caracteres que são adaptativos, é necessário que o agricultor tenha a capacidade de perceber que estes podem estar recombinando e, através de segregação, diminuindo a adaptação de uma determinada etnovariedade ao seu ambiente de cultivo e deve rever constantemente a validade de associar caracteres perceptivos a caracteres adaptativos. Obviamente, esta capacidade deve variar de agricultor para agricultor. Isto significa que um agricultor menos atento, com o decorrer do tempo, corre o risco de estar pensando cultivar uma única etnovariedade com a caracteristica de possuir cor de folha jovem roxa por exemplo, e estar cultivando um grupo de genótipos diferentes sem, no entanto, se dar conta de que cultivar este conjunto de genótipos pode estar interferindo na eficiència com que utiliza os recursos genéticos disponíveis para atender suas necessidades. Daí a importância de existir um sistema taxonômico relativamente eficiente e baseado também em caracteres adaptativos.

Por outro lado, quando o agricultor seleciona individuos somente em função dos caracteres perceptivos, esperando uma forte correlação entre estes e os caracteres adaptativos que tem interesse, a freqüència dos caracteres neutros ou quase neutros, será governada basicamente por mutação e efeito de amostragem (deriva genética), caso haja recombinação. Se este foi o caso da Roxinha e Rosinha, qualquer fenótipo obtido com isoenzimas (consideradas caracteres neutros) pode ser chamado de Roxinha ou Rosinha, desde que tenham caracteres fenotípicos compativeis com os nomes das etnovariedades, ou seja cor de ramos e folhas novas roxa ou rosa respectivamente. É claro que isto não deve ocorrer somente com etnovariedades cujos nomes sejam reflexo de certo caráter fenotípico, mas o fenômeno se torna muito mais óbvio usando estas etnovariedades como exemplo.

Há, ainda, a possibilidade de que nomes derivados de caracteres perceptivos como Roxinha, Rosinha, Vassourinha (clara alusão à forma da folha) etc. sejam recorrentes em diferentes regiões e sejam representadas por genótipos completamente diferentes, pois, dependendo da história evolutiva da etnovariedade, determinados caracteres adaptativos 
podem se tomar associados com um ou outro caráter perceptivo. Assim, é possivel imaginar que em Cananeia exista uma "Roxinha" bem adaptada a solos fracos enquanto que em Ubatuba exista uma "Roxinha" adaptada somente a solos férteis. Isto significa que se um agricultor de Ubatuba obtiver uma "Roxinha" de Cananéia esperando que ela se comporte como a "Roxinha" de Ubatuba, a eficiència com que ele utiliza seus recursos será comprometida e reforça a afirmaçào anterior de que o agricultor deve rever constantemente a validade de associar caracteres perceptivos à adaptativos.

Boster (1984) afirma que a taxonomia local é útil em relação à seleção operada pelo agricultor, pois, ao invés de identificar e avaliar a performance de individuo por individuo, classificando-os em grupos é possivel, quando for realizada a seleção, extender a avaliação para toda uma classe de individuos. Além disso, o sistema taxonômico deve servir nào so para um agricultor, mas para toda uma comunidade, permitindo que quando um agricultor fizer referència à determinada etnovariedade para outro agricultor, ambos pensem na mesma etnovariedade. Isto é importante quando há trocas de etnovariedades entre agricultores, principalmente se estas etnovariedades são adaptadas a condições ambientais especificas.

\subsection{Distância genética entre as roças}

Embora as isoenzimas tenham sido consideradas caracteres fenotipicos, sua alta repetibilidade e baixa variação devido ao ambiente permitem que sejam tratadas como caracteres genotipicos. Deste modo, pode-se, a partir dos dados obtidos com isoenzimas, fazer inferèncias a respeito das distàncias genéticas entre as roças, as quais podem ser observadas no dendrograma da Figura 9. Este dendrograma foi construido de forma hierarquizada considerando a distància média entre roças e comparando com a distância dentro de roças. Utilizou-se para isto a matriz de distâncias calculada a partir da matriz de similaridades médias discutida no item 3.7.3. 
Pode-se observar claramente que as roças FA e FO estão bem separadas das demais. É fácil entender isto, considerando que há um predominio da etnovariedade Marica (M) nestas roças, o que não ocorre nas demais. É curioso que a roça DFP, apesar de pertencer ao mesmo agricuitor de DFG é mais distante da última que a roça AG.

Figura 9- Dendrograma representando a distäncia genética entre as roças estudadas construido baseado em dados de isoenzimas.

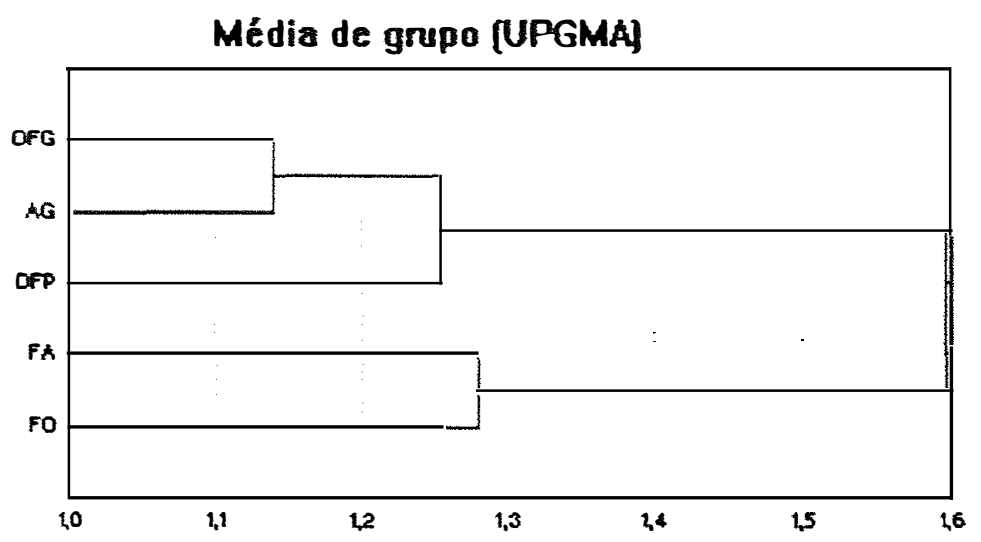

$\mathrm{O}$ fato das roças FA e FO formarem um grupo separado das demais é coerente com o fato de que estas roças foram submetidas a uma alteração do manejo e pode ser uma evidência de que há uma correlação entre manejo e a composição genotípica das roças. Obviamente é só uma evidência e um quadro mais completo será construído com as próximas análises e o resultado das entrevistas com os agricultores. 


\subsection{Diversidade fenotípica nas roças e a relação com fertilidade do solo}

A necessidade de realizar a amostragem em roças separadas no agricultor AG para caracteres isoenzimáticos e morfológicos criou um problema metodológico que precisou ser tratado com certo cuidado. A idéia inicial era construir um PCA incluindo a diversidade de cada carater morfológico e isoenzimático analisado expressa pelo índice de Shannon-Weaver normalizado, além das variáveis de fertilidade do solo por roça. Contudo, para que isso pudesse ser feito na situação real seria necessário assumir ou que ambas as roças de AG fossem compostas das mesmas etnovariedades em proporções semelhantes ou que pelo menos a magnitude da diversidade genética das duas fosse semelhante. Estes pressupostos são um pouco arriscados e o problema foi abordado em partes.

Primeiramente foi construido um gráfico biplot (Figura 10) envolvendo apenas os indices de Shannon-Weaver obtidos com isoenzimas e variáveis referentes à fertilidade do solo. As variáveis escolhidas para representar a fertilidade são $\mathrm{P}, \mathrm{K}$ e \%MO, as quais, segundo a literatura, são fundamentais na dinâmica da fertilidade na agricultura tropical autóctone e mostraram variaçào significativa entre as roças alteradas e tradicionais, possibilitando a utilizaçào de médias destas variáveis por roça, representadas por Pmed, Kmed e MOme.

Pode-se observar no biplot da Figura 10 que existe uma tendência de que um aumento de fertilidade do solo seja acompanhado por um aumento de diversidade isoenzimática nas roças de mandioca. As roças FA e FO ficaram isoladas com relação à fertilidade e diversidade. $\mathrm{O}$ único sistema isoenzimático que não mostrou esta tendência foi o $\mathrm{MDH}$ sendo as roças FA e FO comparáveis às roças AG e DFP. O isolamento das roças FA e FO é coerente com o dendrograma representando as distâncias genéticas entre as roças da Figura 9.

A partir dos indices de Shannon-Weaver normalizados referentes a diversidade isoenzimática de cada roça (Tabela 24), foi realizada uma análise de variância hierarquizada, a qual pode ser observada na Tabela 25. 
Figura 10- Biplot envolvendo os índices de Shannon-Weaver para sistemas isoenzimáticos e médias de $\mathrm{P}, \mathrm{K}$ e \%MO (Pmed, Kmed e MOme respectivamente) por roça.

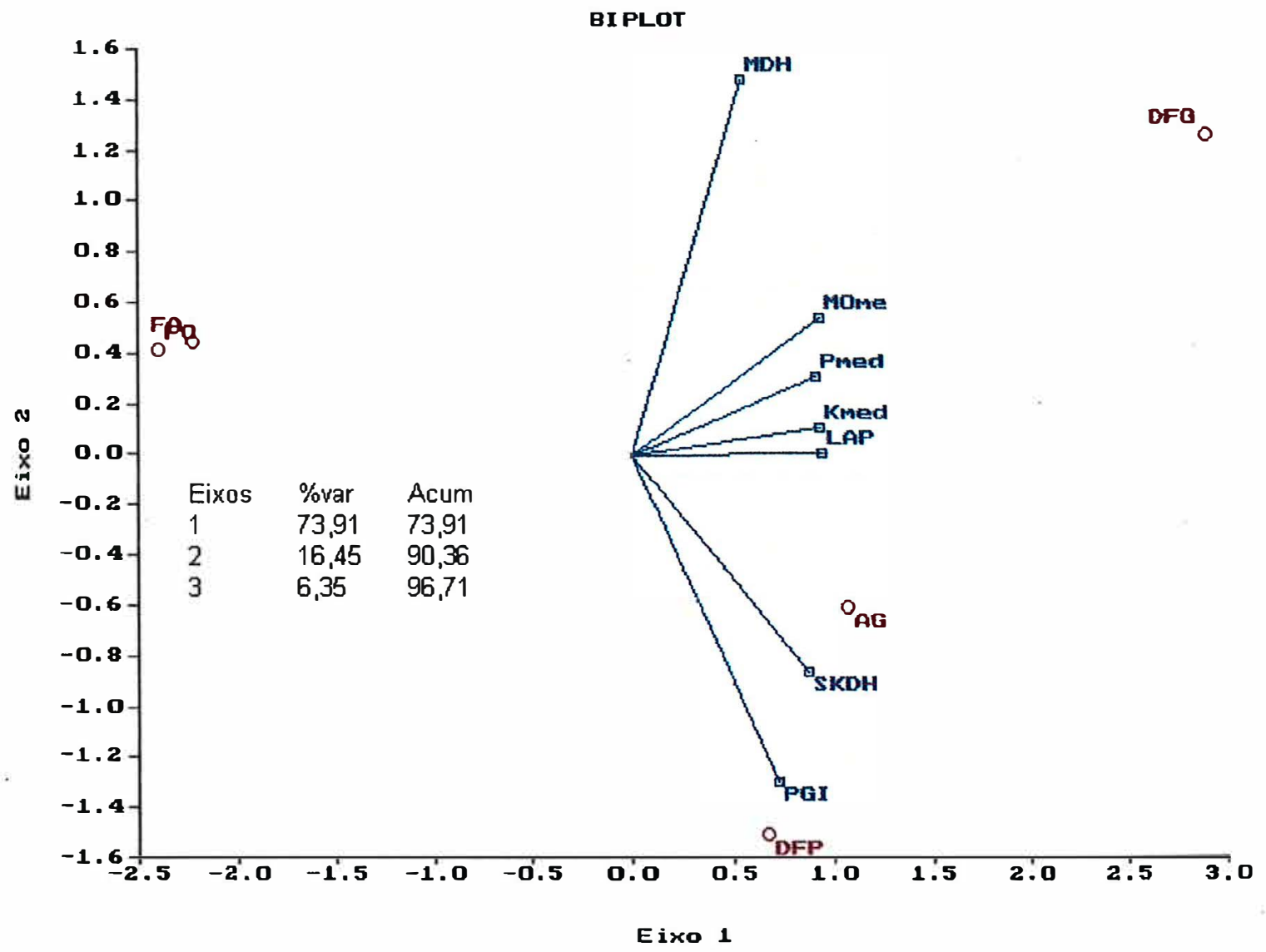

Tabela 24- Índices de Shannon-Weaver normalizados por caráter isoenzimático e por roça.

\begin{tabular}{|l|l|l|l|l|}
\hline Roças & MDH & PGI & LAP & SKDH \\
\hline DFG & 0,5800 & 0,3285 & 0,4940 & 0,8642 \\
\hline DFP & 0,2576 & 0,5033 & 0,4056 & 0,8823 \\
\hline AG & 0,4834 & 0,5177 & 0,4334 & 0,9692 \\
\hline FO & 0,4163 & 0,1443 & 0,2970 & 0,4274 \\
\hline FA & 0,315 & 0,0000 & 0,3376 & 0,4600 \\
\hline
\end{tabular}


Tabela 25- Análise de variància hierarquizada dos indices de Shannon-Weaver para caracteres isoenzimáticos.

\begin{tabular}{lcccc}
\hline Fonte de var. & Soma de quad. & G. L. & Quad. médio & F \\
\hline Roças & 0,3448 & 4 & 0,0862 & $4,87^{*}$ \\
Isoenzimas/roça & 0,5036 & 3 & 0,1679 & $9,49^{* *}$ \\
erro & 0,2123 & 12 & 0,0177 & \\
\hline
\end{tabular}

A análise de variància mostra diferenças significativas tanto para roças quanto para isoenzimas.

Construiu-se, então, um gráfico biplot incluindo apenas os indices de ShannonWeaver referentes à diversidade dos caracteres morfológicos analisados, o qual pode ser observado na Figura 11, lembrando que a roça AG ưilizada nesta análise não é a mesma utilizada para a obtenção de dados isoenzimáticos.

Observa-se neste caso que as roças FA e FO também possuem menor diversidade fenotípica que as demais. É interessante notar que a roça DFP supera a roça AG em termos de diversidade fenotipica para uma determinada quantidade de caracteres como LD/L LM/L, M6, M15, M22 e M16, enquanto que AG supera DFP nos caracteres M2, $\mathrm{P} / \mathrm{F}, \mathrm{M} 1, \mathrm{M} 3, \mathrm{M} 21$ e M4.

$\mathrm{Na}$ Tabela 26 observam-se os indices de Shannon-Weaver normalizados para cada caráter morfológico de cada roça. Uma análise de variância hierarquizada também foi realizada com estes indices (Tabela 27) e mostra diferenças significativas para roças e caracteres. 
Tabela 26- Índices de Shannon-Weaver normalizados por caráter morfológico e por roça.

\begin{tabular}{|lllllll|}
\hline Roças & M1 & M2 & M3 & M4 & M6 & M15 \\
\hline DFG & 0,2942 & 0,5168 & 0,5691 & 0,7280 & 0,3255 & 0,4172 \\
DFP & 0,1054 & 0,0000 & 0,4228 & 0,5850 & 0,4101 & 0,7367 \\
AG & 0,5150 & 0,2538 & 0,6451 & 0,7631 & 0,0892 & 0,5415 \\
FO & 0,0000 & 0,1044 & 0,3869 & 0,4932 & 0,1064 & 0,2814 \\
FA & 0,1922 & 0,4853 & 0,4000 & 0,4412 & 0,1043 & 0,2730 \\
\hline Roças & M16 & M21 & M22 & LM/L & LD/L & P/F \\
\hline DFG & 0,8208 & 0,6988 & 0,9612 & 0,5710 & 0,4331 & 0,9181 \\
DFP & 0,7747 & 0,4926 & 0,9183 & 0,6644 & 0,5946 & 0,3446 \\
AG & 0,4581 & 0,7198 & 0,2423 & 0,3110 & 0,3362 & 0,7365 \\
FO & 0,3267 & 0,4320 & 0,0000 & 0,1557 & 0,2215 & 0,6806 \\
FA & 0,4412 & 0,4956 & 0,0000 & 0,3924 & 0,2897 & 0,6217 \\
\hline
\end{tabular}

Tabela 27- Análise de variância hierarquizada dos índices de Shannon-Weaver para caracteres morfológicos.

\begin{tabular}{lcccc}
\hline Fonte de var. & Soma de quad. & G.L. & Quad. médio & $\mathrm{F}$ \\
\hline Roças & 0,9613 & 4 & 0,2403 & $6,89^{* *}$ \\
Caráter/roça & 1,1741 & 11 & 0,1068 & $3,06^{* *}$ \\
Erro & 1,5347 & 44 & 0,0349 & \\
\hline
\end{tabular}


Figura 11- Biplot envolvendo os índices de Shannon-Weaver somente para caracteres morfológicos.

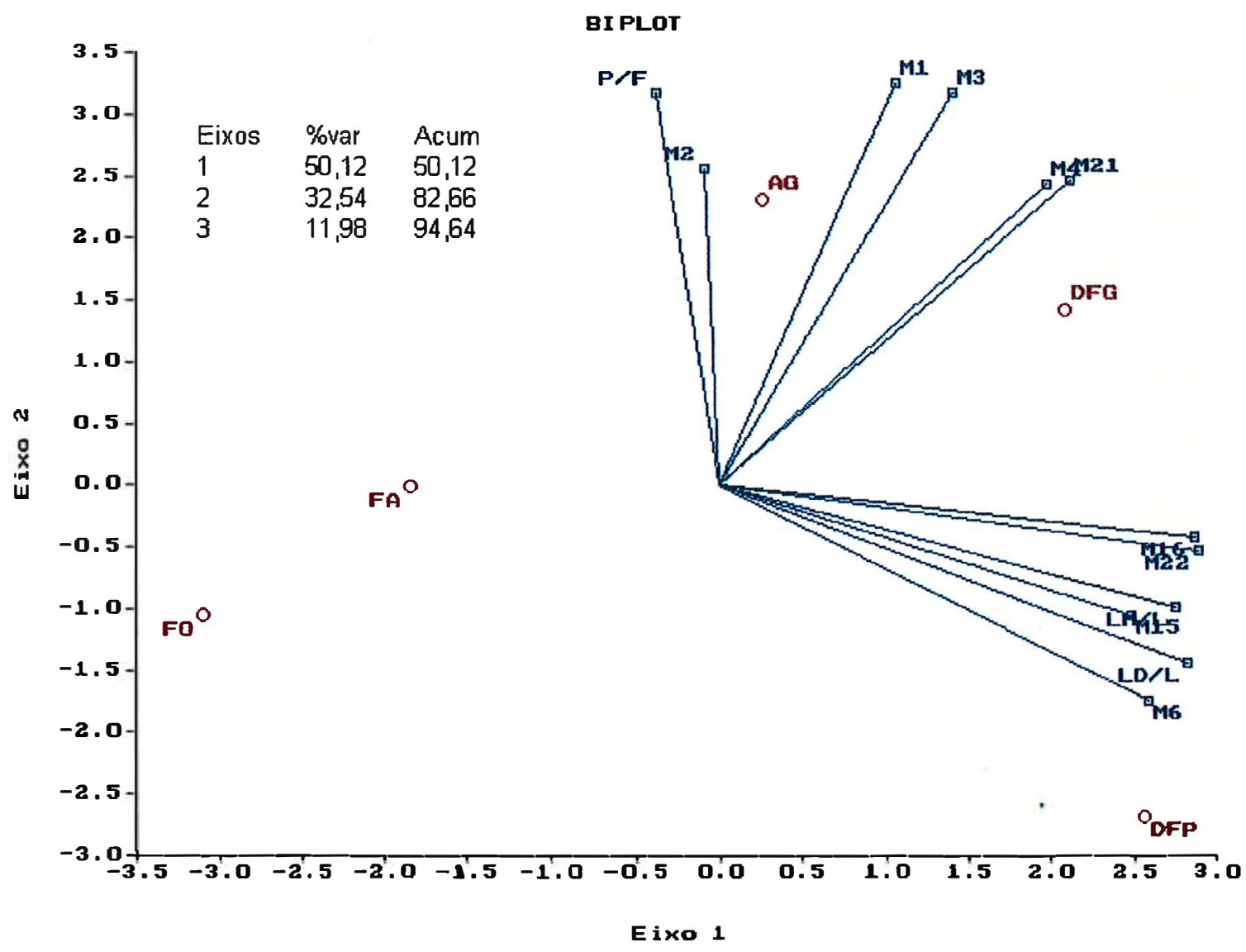

Unir diversidade obtida a partir de isoenzimas, caracteres morfológicos e fertilidade de solo num único PCA a rigor só seria possível utilizando apenas os dados das roças DFG, DFP, FA e FO, pois foram obtidos a partir de uma mesma população. Foi construído um gráfico biplot (Figura 12), envolvendo os índices de Shannon-Weaver calculado para variáveis isoenzimáticas e morfológicas apenas para as roças DFG, DFP, FA e FO e utilizando a média das variáveis $\mathrm{P}, \mathrm{K}$ e \%MO para cada roça. É nítido neste biplot que a tendência de variação conjunta da diversidade expressa pelos índices de Shannon-Weaver e fertilidade do solo aumentando em direção às roças tradicionais se mantém. As variáveis M2, P/F, MDH e M1 são variáveis que possuem diversidades semelhantes nas roças DFP, FA e FO. 
Uma análise de variância hierarquizada dos índices de Shannon-Weaver considerando todos os caracteres (morfológicos e isoenzimáticos) e as roças DFG, DFP, FA e FO mostrou diferenças significativas tanto para roças como para caráter, como pode ser observado na Tabela 28.

Figura 12- Biplot envolvendo os índices de Shannon-Weaver para caracteres morfológicos e isoenzimáticos das roças DFG, DFP, FA e FO, além das médias de $\mathrm{P}, \mathrm{K}$ e \%MO (Pmed, Kmed e MOme respectivamente) por roça.

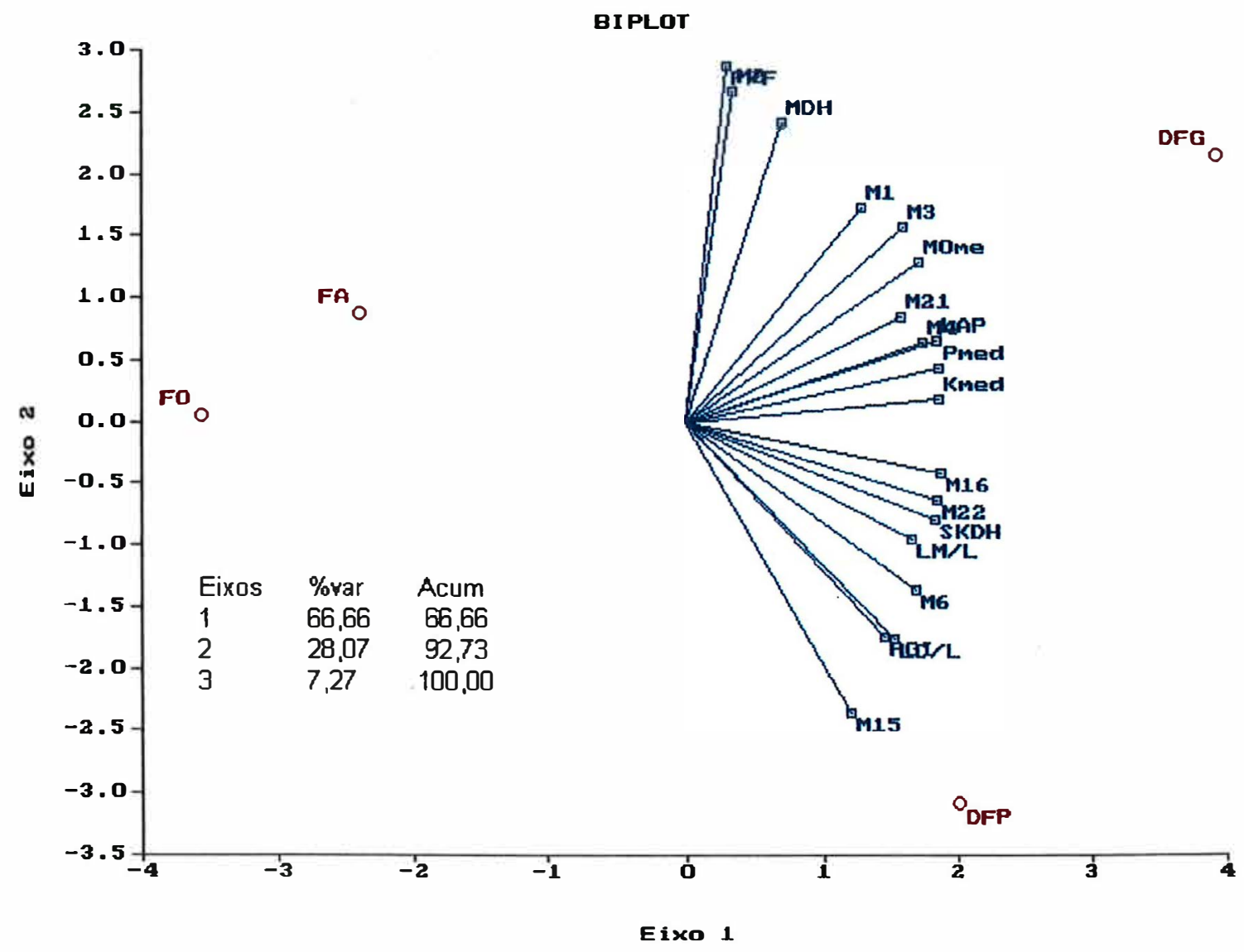


Tabela 28- Análise de variância hierarquizada conjunta dos índices de Shannon-Weaver para caracteres morfológicos e isoenzimáticos considerando as roças DFG, DFP, FA e FO.

\begin{tabular}{lcccc}
\hline Fonte de var. & Soma de quad. & G.L. & Quad. médio & F \\
\hline Roça & 1,1456 & 3 & 0,3819 & $12,06^{* *}$ \\
Caráter/roça & 1,2912 & 15 & 0,0861 & $2,72^{* *}$ \\
Erro & 1,4248 & 45 & 0,0317 & \\
\hline
\end{tabular}

A inclusão da roça $A G$ na mesma análise realizada anteriormente, depende, como já foi discutido, de alguns pressupostos. Assumir que um mesmo agricultor utiliza as mesmas etnovariedades em todas as suas roças em proporções semelhantes, as quais devem, portanto, possuir diversidades semelhantes, não é algo inteiramente fora de propósito, pois suas roças são fonte primária de manivas (etnovariedades) para montar outras roças, como foi afirmado por todos os agricultores. Segundo estes agricultores, a troca de manivas entre agricultores é comum mas não predomina como fonte de material para uma nova roça, a não ser que haja uma perda maciça de etnovariedades. Sendo assim, foi construido um gráfico biplot envolvendo todas as roças, seus respectivos índices de Shannon-Weaver para caracteres morfológicos e isoenzimáticos e a média das variáveis de solo $\mathrm{P}, \mathrm{K}$ e \%MO por roça, como mostra a Figura 13.

A análise de variância hierarquizada dos índices de Shannon-Weaver para todos os caracteres de todas as roças pode ser observada na Tabela 29 e mostra diferenças significativas para roça e caráter.

Tabela 29- Análise de variância hierarquizada dos índices de Shannon-Weaver para caracteres isoenzimáticos e morfológicos envolvendo todas as roças.

\begin{tabular}{lcccc}
\hline Fonte de var. & Soma de quad. & G.L & Quad. médio & $\mathrm{F}$ \\
\hline Roça & 1,2218 & 4 & 0,3054 & $10,03^{* *}$ \\
Caráter/roça & 1,6771 & 15 & 0,1118 & $3,67^{* *}$ \\
Erro & 1,8278 & 60 & 0,0305 & \\
\hline
\end{tabular}


Figura 13- Biplot envolvendo os índices de Shannon-Weaver para caracteres isoenzimáticos e morfológicos de todas as roças e fertilidade do solo expressa pelas médias de $\mathrm{P}, \mathrm{K}$ e \%MO (Pmed, Kmed e MOme respectivamente) por roça.

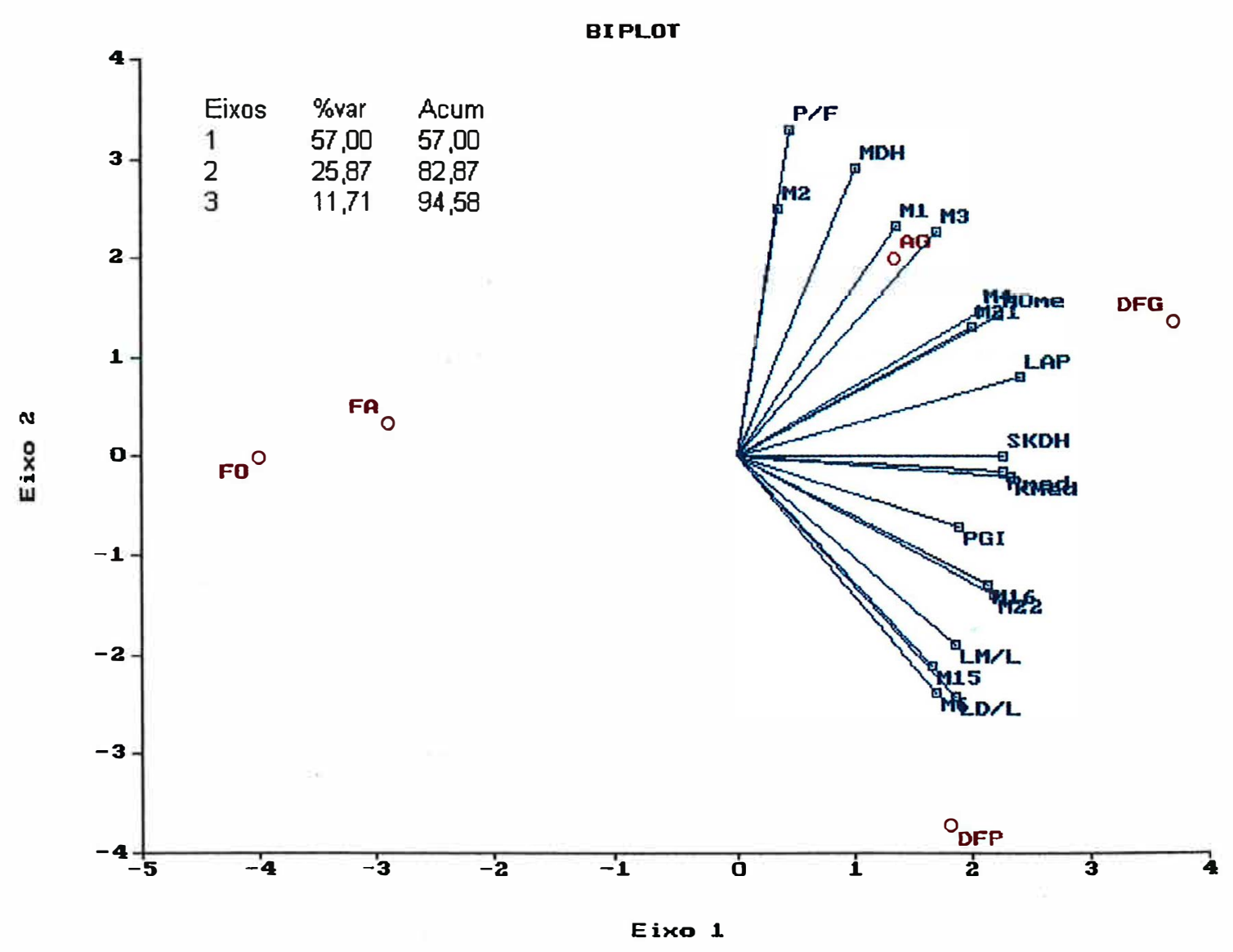

O pressuposto de homocedasticidade e normalidade foi respeitado em todas as análises de variância, o que foi confirmado pelo teste de Levene para heterogeneidade de variâncias e a curva probabilidade de normalidade categorizada, ambos calculados pelo pacote estatístico Statistica versão 5.

A tendência de associação entre diversidade isoenzimática e morfológica e . fertilidade de solo continua neste caso, pois as roças FA e FO continuam isoladas com menor diversidade e fertilidade. De fato, analisando todos os biplots gerados, nota-se que 
as posiçōes relativas das roças AG, DFG e DFP se alteram dependendo de qual variável se introduz no PCA. Por outro lado, é recorrente em todas análises o isolamento das roças FA e FO com menor diversidade e menor fertilidade de solo. É possível, portanto, concluir que há de fato uma associação entre diversidade genética e fertilidade de solo, a qual separa as roças FA e FO (consideradas alteradas) das roças DFG, AG e DFP

(consideradas tradicionais), sendo que tanto as diferenças em termos de diversidade fenotipica quanto as diferenças nas variáveis referentes à fertilidade do solo $(\mathrm{P}, \mathrm{K}$ e $\% \mathrm{MO}$ ) foram estatisticamente significativas.

Uma das criticas que se faz com relação ao uso do índice de Shannon-Weaver para expressar diversidade é o fato de que este superestima a diversidade de pequenas frações. No caso das roças, se isto realmente acontece, a identificação de uma menor diversidade fenotipica para as roças alteradas, mesmo existindo a possibilidade desta diversidade estar superestimada, vem reforçar a idéia de que há uma redução drástica da diversidade em direção às roças alteradas.

\subsection{Distribuição da diversidade}

Utilizou-se para repartir a diversidade fenotipica dentro de roças e entre roças apenas as roças consideradas tradicionais, DFG, DFP e AG. Com isso espera-se obter uma idéia de como se distribui a diversidade genética de mandioca em sistemas tradicionais. Se, ao contrário, as roças alteradas tivessem sido incluídas, poderia estar também sendo incluido um viés pelo fato de terem sido alteradas. No caso do agricultor $A G$, em que foi coletado material para isoenzimas separadamente da amostragem para caracteres morfológicos, não há problemas na interpretação, pois os caracteres foram tratados separadamente. A Tabela 30 mostra a distribuição da diversidade expressa pelos indices de Shannon-Weaver nas roças mencionadas para caracteres isoenzimáticos e morfológicos, segundo o esquema descrito no item 2.7 , no qual $\mathrm{H}_{0}{ }^{\prime} / \mathrm{H}_{\mathrm{t}}$ ' representa a diversidade dentro de roças e $1-\mathrm{H}_{0}$ '/ $\mathrm{H}_{4}$ ' a diversidade entre roças. 
Tabela 30-Repartição da diversidade entre roças e dentro de roças para cada caráter analisado considerando as roças $\mathrm{AG}, \mathrm{DFG}$ e DFP.

\begin{tabular}{|lllllllll|}
\hline & MDH & PGI & LAP & SKDH & M6 & M15 & M16 & M21 \\
\hline $\mathrm{H}_{\mathrm{t}}{ }^{\prime}$ & 0,49 & 0,48 & 0,48 & 0,97 & 0,28 & 0,66 & 0,73 & 0,78 \\
$\mathrm{H}_{\mathrm{o}}{ }^{\prime}$ & 0,44 & 0,45 & 0,44 & 0,90 & 0,27 & 0,56 & 0,68 & 0,64 \\
$\mathrm{H}_{\mathrm{o}}{ }^{\prime} / \mathrm{H}_{\mathrm{t}}{ }^{\prime}$ & 0,89 & 0,94 & 0,92 & 0,94 & 0,99 & 0,85 & 0,93 & 0,81 \\
$1-\mathrm{H}_{\mathrm{o}}{ }^{\prime} / \mathrm{H}_{\mathrm{t}}{ }^{\prime}$ & 0,11 & 0,06 & 0,08 & 0,06 & 0,01 & 0,15 & 0,07 & 0,19 \\
\hline & M22 & M1 & M2 & M3 & M4 & P/F & LM/L & LD/L \\
\hline $\mathrm{H}_{\mathrm{t}}{ }^{\prime}$ & 0,84 & 0,39 & 0,66 & 0,76 & 0,86 & 0,84 & 0,53 & 0,46 \\
$\mathrm{H}_{\mathrm{o}}{ }^{\prime}$ & 0,67 & 0,30 & 0,26 & 0,54 & 0,69 & 0,67 & 0,51 & 0,45 \\
$\mathrm{H}_{\mathrm{o}}{ }^{\prime} / \mathrm{H}_{\mathrm{t}}{ }^{\prime}$ & 0,80 & 0,79 & 0,39 & 0,72 & 0,80 & 0,80 & 0,97 & 0,99 \\
$1-\mathrm{H}_{\mathbf{o}}{ }^{\prime} / \mathrm{H}_{\mathrm{t}}{ }^{\prime}$ & 0,20 & 0,21 & 0,61 & 0,28 & 0,20 & 0,20 & 0,03 & 0,01 \\
\hline
\end{tabular}

A maior parte da diversidade fenotípica é concentrada dentro de roças para todos os caracteres, exceto M2. Nos caracteres PGI, LAP, SKDH, M6, M16, LM/L e LD/L a diversidade é concentrada praticamente só na roça. É interessante notar que aqueles caracteres relacionados com pigmentação M1, M2, M3, M4, M15, M21 e M22, os quais entram na discussão de Boster (1985) a respeito da amplificação da diversidade de caracteres perceptivos, não são tão concentrados dentro de roça quanto os demais. É importante lembrar que as roças escolhidas situam-se em locais ecologicamente semelhantes quanto ao solo, clima e vegetação, não tendo sido escolhidas roças em áreas mais encharcadas, como várzeas ou solos mais arenosos, como solos de restinga, o que talvez equilibrasse a distribuição da diversidade, visto que os agricultores talvez escolham diferentes etnovariedades para diferentes ambientes

Sendo possivel assumir que tanto os caracteres isoenzimáticos quanto os morfológicos escolhidos representam caracteres genotípicos, dada a baixa influência ambiental nestes caracteres, a principal conseqüência deste padrão de distribuição da diversidade em termos de conservação in situ e ex situ é que, da mesma forma que uma 
expedição de coleta de germoplasma necessita visitar apenas uma roça para coletar uma parte considerável da diversidade genetica, um agricultor pode recorrer a um vizinho ou a uma roça própria (se possuir mais de uma) quando necessitar restabelecer a diversidade que porventura seja perdida. A extensão do fato de que poucas roças podem representar grande parte da diversidade genética da região pode conduzir à afirmação de que bastaria conservar uma rọa de um agricultor para realizar conservação in situ. É preciso, no entanto, ter em mente que a grande vantagem da conservação in situ é a manutenção da dinàmica evolutiva nas populaçōes cultivadas. Por exemplo, a chance de um recombinante favorável ou mesmo um mutante favorável ser criado é grandemente ampliada considerando-se toda uma comunidade praticando agricultura em comparaçào com uma roça de um agricultor.

É também importante ressaltar que, sendo os caracteres estudados controlados na sua maioria por poucos genes, a diversidade estudada é pouco representativa do genoma da mandioca. Por isso, existe a possibilidade de que, acrescentando caracteres quantitativos ao estudo, a distribuição da diversidade seja um pouco alterada.

Este padrão de distribuição da diversidade pode ser considerado um reflexo do forte fluxo gênico entre roças e agricultores. É interessante comentar que os agricultores AG e DF, apesar de se conhecerem, estão estabelecidos bem afastados um do outro e é provável que as trocas de etnovariedades sejam realizadas indiretamente através de outros agnicultores.

Tendo a distribuição da diversidade este padrão, assumir que duas roças do mesmo agricultor (AG) tem diversidades semelhantes se torna menos arriscado e subsidia a análise de componentes principais envolvendo todas as roças de todos agricultores com todos os caracteres em conjunto com os dados de fertilidade de solo realizada no ítem 4.5. 


\subsection{Seleção, manejo e redução da diversidade.}

Ficou evidente uma associação entre fertilidade do solo e diversidade genética nas roças de mandioca. A constatação de um processo seletivo que levou a uma perda de diversidade genética depende de assumir, ou mesmo de constatar, que os agricultores das roças FA e FO cultivavam em suas roças, antes da alteração do manejo, diversidade comparável à encontrada nas roças DFG, DFP e AG. Antes disso, contudo, é conveniente verificar se há coerència entre aquilo que os dados (tanto de fertilidade do solo como diversidade) mostram com o que seria provável de acordo com a literatura.

Primeiramente, se é verdade que os agricultores FA e FO faziam um manejo tradicional de corte, queima e abandono e deixaram de faze-lo para estabelecer agricultura em locais fixos sem uso de adubação e com períodos de pousio curtos, espera-se, segundo a literatura, que haja uma queda dos teores de potássio $(\mathrm{K})$, fósforo (P), do teor de matéria orgânica (\%MO), do $\mathrm{pH}$ e da atividade microbiana, principalmente pelo fato das condições originais do solo serem de baixa saturação de bases. De fato, todos, exceto $\mathrm{pH}$ e atividade microbiana que não foi quantificada, mostraram diferenças significativas entre roças, tendo as roças FA e FO os menores valores, levando a crer que a fertilidade do solo nas roças FA e FO se comporta como previsto. Segundo a literatura, o elemento mais limitante para a cultura da mandioca em cultivos sucessivos sem adubação é o potássio. A absorção de fósforo também pode ser bem comprometida pela redução de sua disponibilidade no solo quando é fixado pelo aluminio em niveis baixos de $\mathrm{pH}$ e redução da população de micorrizas. Baseado nestes fatos, é de se esperar que, a criação de um novo ambiente nas roças FA e FO esteja criando também uma pressão de seleção sobre a população de mandiocas. Entretanto, pressão de seleção só pode significar respostas adaptativas da população caso haja variabilidade genética em relação a esta pressão. É dificil afirmar se na população de mandiocas existente anteriormente à introdução da alteração no manejo agrícola existia ou não variabilidade com relação à tolerância à baixa fertilidade do solo. Tendo sido encontrada na literatura variabilidade genética quanto aos níveis de absorção de fósforo e 
exportação de potássio e enxofre, é de se esperar que tenha existido variabilidade quanto à fertilidade do solo na referida população. Diante deste cenário, a existência de um processo seletivo levando a perda de diversidade genética passa a ser bem mais consistente.

Quanto ao manejo praticado atualmente pelos agricultores AG e DF, é notória a semelhança com o manejo nas roças de mandioca de Ubatuba e os relatos de Anchieta e Hans Staden descritos por Schmidt (1958) o que reforça a idéia de que este manejo temse mantido inalterado na região durante séculos. Mesmo condenados a alterar suas práticas de manejo, os agricultores FA e FO tentam adaptar o sistema de manejo ao modo mais tradicional possivel, deixando pequenas áreas em pousio pelo máximo de tempo possivel, não utilizando adubação, plantando em covas e outros detalhes representativos da agricultura autóctone.

Uma informação muito relevante para completar o quadro tem relação com a memória da diversidade que era reconhecida pelos agricultores FA e FO antes da implantação do parque. Ambos afirmaram que plantavam as etnovariedades Zumira, Mucaé, Santilena, Roxinha, Maricá, Mata-Fome, Inéu, Aipi-Preta, Santista, Rosinha, Tupã, Landi-Ferro, Landi-Branco, Mandioca-Doce, Gongá e Ruivinha. Em contraste, foi amostrada nestas roças basicamente a etnovariedade Maricá e, em pequena proporção, Zumira, Roxinha, Rosinha, Dois-Irmãos, Aipi-Preto, e Santilena. Nota-se que a diversidade que se tem na memória é bem maior que a atual e, considerando que cada uma destas etnovariedades citadas na primeira lista pode ter sido composta por vários genótipos, a diversidade real se multiplica. Em contrapartida, a tendência de fazer o plantio com a predominância de uma etnovariedade, como é feito atualmente nestas roças, tende a causar perdas de genótipos dentro das outras etnovariedades cultivadas em menor proporção, pois estas começam a ser representadas por poucos indivíduos, o que é condição básica para ocorrência de deriva genética.

Finalmente, foi obtido uma descrição precisa de como os agricultores FA e FO reagiram frente ao novo ambiente que foi criado pela modificação do manejo. Segundo estes agricultores, o parque começou a afetar suas vidas cerca de 10 a 15 anos antes da 
data da entrevista (1997), o que coincide aproximadamente com a data de desapropriação do núcleo Picinguaba em 1984. A partir desta época começou a limitação da área para derrubada e plantio, a redução do período de pousio e da fertilidade, a qual foi percebida pelos agricultores, segundo seus relatos. O agricultor FA informou que na época da implantação do parque, a etnovariedade Maricá, a mesma que predomina em ambas as roças hoje em dia, era plantada em pequena proporção em relação às demais. A partir do momento que foi percebido que a Maricá era a mais adaptada das etnovariedades às novas condições, segundo o critério produção, passou-se a plantá-la em proporções cada vez maiores, o que confirma a existência de variabilidade genética para tolerância à baixa fertilidade do solo na população original e suporta, conjuntamente com as evidências anteriores, a conclusão de que realmente houve um processo seletivo, o qual acarretou redução da diversidade genética na população de mandioca existente nas roças cultivadas pelos agricultores FA e FO. É interessante o relato do agricultor $A G$, que afirma ter testado a Maricá nas suas roças e que esta não respondeu bem, tendo sido observado que respondia muito bem à beira-mar, local de solo arenoso e bem mais pobre que os solos dos morros.

O agricultor FA estima que passou a plantar predominantemente Maricá cerca de cinco anos antes da entrevista, aproximadamente em 1992. Supondo que em 1984 fèz uma roça nos padrões tradicionais, já que não havia restrições anteriormente, a qual, provavelmente, deve ter durado cerca de 2 a 3 anos e, tendo duas áreas de plantio, é possivel que ainda tenha conseguido uma segunda roça tradicional após 1984. Supondo ainda, que a diferença na fertilidade do solo tenha sido notada aproximadamente 3 anos após a implantação do parque, ou seja em 1987, e só então o agricultor iniciou a seleção, este processo levou cerca de 5 anos, ou aproximadamente 3 ciclos de plantio (considerando 1,5 anos por ciclo), para transformar uma etnovariedade que era parcamente cultivada em predominante. Obviamente estas datas estão sujeitas a variação, mas com fazendo estas suposições é possivel ter uma noção da velocidade com que o processo ocorreu. 
Há evidências de que, mantida a restrição ao plantio, a etnovariedade Maricá deverá predominar em toda a região norte de Ubatuba. Uma delas é o fato de que, segundo os agricultores FA e FO, todos os agricultores da região da Fazenda da Caixa passaram a cultivar predominantemente a Maricá. Outra evidência é que no bairro do Camburi, situado cerca de $10 \mathrm{~km}$ da Fazenda da Caixa, o senhor Isaias, afirmou que perdeu várias etnovariedades e que lá se planta predominantemente Maricá. Neste bairro, situado à beira-mar, sendo muito visado pela fiscalização, a agricultura também tem sido restrita a áreas pré-determinadas, não sendo permitida a abertura de novas roças, algo muito parecido com o que ocorre na Fazenda da Caixa.

Seleção não pode ser considerada um fator que inerentemente causa perda de diversidade. Na verdade, seleção em diferentes ambientes aliado a fatores como subdivisão de populaçòes, fluxo gênico entre subpopulações e mesmo deriva genética podem contribuir para manutenção da diversidade genética. Populações submetidas a pressões de seleção que variam aleatoriamente sua direção também podem ser passiveis de manter diversidade genética. Há uma vasta literatura envolvendo modelos que comprovam, ao menos teoricamente, a possibilidade da seleção contribuir para a manutenção da diversidade genética de populações, principalmente envolvendo seleção em diferentes ambientes ou em ambientes variáveis e pode-se citar como referências Levene (1953), Haldane \& Jayakar (1962), Hedrick (1976), Hedrick (1986) e Felsenstein (1976). O que caracteriza particularmente o caso das roças FA e FO é o fato de que a pressão de seleção criada pela alteração do manejo se manteve constantemente numa unica direção, a qual levou à adaptação de uma etnovariedade a um ambiente bem especifico de menor fertilidade. Como a unidade de seleção é o clone, a eficiência desta seleção é bem alta, o que fica evidente pela taxa com que se substituiu outras etnovariedades pela Maricá. Porém, a medida que vai-se diminuindo a diversidade genética, as oportunidades de seleção começam a ficar escassas, principalmente pelo fato que novos genótipos gerados por recombinação ou mesmo mutação, além de ocorrerem com freqüência relativamente baixa, tem chances ainda menores de serem mais adaptados às novas condições impostas pelo ambiente. Se por um lado a propagação clonal 
associada com sexual no esquema de agricultura tradicional apresenta uma série de vantagens, especialmente por estar constantemente gerando e principalmente mantendo diversidade, permitindo com isso que a população de clones continue evoluindo indefinidamente, a taxa de extinção de genótipos pela seleção direcional contínua, sem a contrapartida de geração de novos genótipos em taxas compatíveis, transforma a propagação clonal numa grande desvantagem do ponto de vista evolutivo.

Qual seria a interpretação desta seleção direcional contínua identificada no caso das roças FA e FO? Mayr (citado por Lewontin, 1974, p.148) observa que, em geral, o grau de polimorfismo de uma dada espécie tende a decrescer em direção aos limites da distribuição geografica desta espécie, sendo que populações periféricas são freqüentemente monomórficas. Lewontin (1974) acrescenta que a acurácia desta generalização é aumentada se for levado em consideração não somente os limites geográficos mas também os limites ecológicos da distribuição da espécie. A espécie Manihot esculenta, sob esta ótica, ocupa uma gama de ambientes com características edafo-climáticas especificas, sendo o ambiente ideal muito provavelmente aquele gerado quando uma roça é aberta. À medida que estas características vão se afastando da norma, ambientes ecologicamente marginais para a espécie podem vir a ser ocupados por cada vez menos genótipos. A redução drástica da fertilidade geral do solo deve criar um ambiente marginal para mandioca sobreviver e atender as necessidades de quem a cultiva. A existência de um ou poucos genótipos adaptados (com alta aptidão darwiniana) a este novo ambiente, como a etnovariedade Maricá, tem como consequêencia um rápido aumento da freqüência deste(s) genótipo(s) na população em detrimento dos demais.

\subsection{Seleção natural e artificial na agricultura tropical autóctone}

Segundo o modelo de domesticação proposto por Cury (1993) e ampliado por Martins $^{9}$, a seleção natural atua basicamente em plantas originadas por sementes, as

\footnotetext{
${ }^{9}$ Martins, P.S. (Departamento de Genćtica da Escola Supcrior de Agricultura "Luiz de Quciroz"). Comunicação pessoal.
} 
quais passam por uma série de episódios de seleção muito semelhantes aos que estariam ocorrendo em plantas selvagens propagadas por semente. De fato, resgatando a história vital destes indivíduos, é possivel entender como se dá a seleção. Primeiramente, a semente deve ser produzida e ser viável (fecundidade). Ao ser lançada pela deiscência da cápsula que a contém, a semente pode ou não encontrar um sítio adequado para germinar e se estabelecer. A semente pode germinar em qualquer época, principalmente se possuir dormência. Há certos tipos de dormência em que fatores ambientais desencadeiam 0 processo de germinação (Begon et al., 1996) e isto bem pode ocorrer com a mandioca para favorecer a germinação quando a roça for aberta, o que é coerente com o fato de que os ancestrais selvagens da mandioca são espécies colonizadoras de clareiras e heliófilas, mas tem como condição básica que a floresta secundária derrubada tenha ocupado o lugar de uma roça abandonada, a qual deve ter sido capaz de produzir um banco de sementes. Tanto o agricultor DF quanto o agricultor consultado do Camburí informaram ter observado a germinação de sementes de mandioca mesmo em áreas ocupadas por floresta secundária 20 anos ou mais, concordando com as observações de Salick et al. (1997) sobre a existência de um banco de sementes em roças abandonadas. Caso germine quando o agricultor abre uma roça, a planta deve sofrer competição com as outras plantas e a intensidade desta competição depende basicamente de quando, em relação à idade das outras plantas, germinou a semente e em que posição em relação às plantas plantadas pelo agricultor esta se encontra. Já neste período o agricultor começa a perceber a existência destas plantas e influenciar a seleção. Uma plântula de mandioca foi observada no plantio de uma roça pelo agricultor FA a qual acabou sendo arrancada não intencionalmente pelo fato de estar fora do espaçamento. Um agricultor consultado do Camburi costuma arrancar intencionalmente plantas de semente que estejam fora do espaçamento que considera adequado. As plantas de semente podem ser submetidas à herbivoria e doenças em qualquer fase de sua história vital. Recombinantes originados por semente ainda correm o risco de não possuírem boas características de enraizamento de suas manivas. Isto pode ser considerado uma pressão de seleção natural contra indivíduos que não sejam capazes de reprodução vegetativa adequada ao cultivo. 
Portanto, uma vez estabelecido um individuo originário de semente numa roça, tendo este individuo uma boa capacidade de reprodução vegetativa e a não ser por pressões de seleçào que venham atuar somente em indivíduos adultos, o crivo da seleção natural já foi praticamente todo superado. $O$ agricultor não tem necessidade de avaliar se o individuo é ou não resistente a pragas ou doenças, à fertilidade do solo que tem na sua roça ou se tem condições de competir com invasoras ou mesmo com outros genótipos. Avaliar simplesmente fatores que tem interesse, como produção, passa a ser suficiente para o agricultor, já que estes fatores refletem praticamente toda a gama de pressões de seleçào que o individuo teve que superar. Isto concorda com a discussão de Boster (1984) sobre seleçào de mandioca pelos Aguaruna, os quais se demonstraram preocupados basicamente com produção.

A partir do momento que o agricultor percebe a existencia de plantas de semente, é possivel atuar conscientemente sobre o sucesso reprodutivo destes indivíduos. A maioria dos agricultores entrevistados não se preocupa em avaliar a performance de uma planta de semente e isto é compreensivel se esta planta é considerada "a mesma" que as que tem cultivado, como afirma o agricultor AG. Ao contrário, o agricultor DF marca as plantas de semente que encontra e as avalia principalmente em relação à produção, descartandoas ou não de acordo com sua avaliação. É interessante observar que AG acaba incorporando novos genótipos sem perceber e DF os incorpora ou descarta conscientemente, segundo critérios bem definidos. Esta diferença de atitudes deve-se refletir na eficiência com que os agricultores utilizam os recursos genéticos disponiveis. Quando o agricultor AG incorpora genótipos cuja performance é desconhecida, pode estar aumentando a freqüència de genótipos menos adaptados às suas condições e estar reduzindo sua produtividade, por exemplo. $\mathrm{O}$ agricultor $\mathrm{DF}$, por sua vez, deve utilizar com maior eficiência os recursos de que dispõe.

Em contrapartida, os agricultores estão sempre avaliando as respostas das etnovariedades que reconhecem ao ambiente de cultivo e determinam se uma etnovariedade vai ser plantada em maior número que outra baseando-se nestas respostas, como ficou claro no caso dos agricultores FA e FO em relação à Maricá e pelas respostas 
dos outros agricultores. Todos os agricultores entrevistados responderam que avaliam a performance de etnovariedades desconhecidas introduzidas através de trocas com outros agricultores antes de decidirem se incorporam ao seu conjunto ou não, o que pode ser considerado uma outra evidência de que estão atentos à performance das etnovariedades que reconhecem.

Haveria a possibilidade da seleção natural atuar de forma pura após o estabelecimento da roça? A possibilidade disso acontecer deve estar relacionada à existència de fatores que interfiram na capacidade reprodutiva da mandioca, ou seja, na capacidade das plantas produzirem manivas, já que a maniva é a unidade de reprodução da mandioca na agricultura. Ainda hoje, saporém, formiga cortadeira e porco-do-mato sào os principais inimigos da cultura da mandioca no sistema tradicional em Ubatuba e sào capazes de provocar grandes danos. Entretanto, para que a seleção provoque consequeencias na estrutura genética da população, é necessário que haja variabilidade genética nas respostas em relação a estes inimigos. A questão é que todos os agricultores entrevistados afirmaram unanimemente que nenhum destes "inimigos" tem preferência por determinada etnovariedade, o que os caracteriza (os inimigos) como generalistas e, portanto, não se pode considerá-los como agentes seletivos.

Há, contudo, uma possibilidade da ocorrência de seleção natural no estabelecimento da roça. $\mathrm{Na}$ agricultura tropical autóctone, o plantio de uma nova roça é o principal episódio de seleção, como afirma Boster (1984). É nesta fase que o agricultor tem chance de escolher manivas nas roças que possui e introduzir novas etnovariedades de outros agricultores que possam lhe interessar. Para esta atividade, a maniva é a unidade de reprodução e é amplamente reconhecido por todos os agricultores que etnovariedades diferentes tem capacidades diferentes de produzir caules para maniva. Segundo os agricultores, uma planta tem capacidade de produzir 8 a 30 manivas dependendo da etnovariedade à qual pertence ou seja, o valor reprodutivo (sensu Fisher, 1958) de uma planta de mandioca pode variar de 8 a 30 plantas. Portanto, se o agricultor pretende abrir uma roça de tamanho comparável à roça de onde retira manivas, com uma população de plantas semelhante em termos absolutos, basta que na média cada planta da 
segunda seja capaz de produzir efetivamente apenas uma planta na nova roça. Como o valor reprodutivo é relativamente alto, o agricultor tem grande flexibilidade para compor a nova roça com etnovariedades na proporção que julgar mais adequado. Nesta situação, para que houvesse de fato somente seleção natural, o valor reprodutivo de uma dada etnovariedade teria de ser menor que 1 , fazendo com que o agricultor tivesse que preencher a ausência de individuos da referida etnovariedade com individuos de outra etnovariedade para completar a população total. A intensidade de seleção para que isso ocorresse teria que ser muito alta, o que não foi constatado em Ubatuba, pois os principais agentes potencialmente seletivos são na verdade generalistas. Por outro lado, se o agricultor pretende abrir uma roça muito maior e, portanto, aumentar a população em termos absolutos, o valor reprodutivo começa a ser limitante e a seleção puramente natural se torna muito mais provável. A discussão da seleção em populações estáveis e crescentes em termos absolutos é antiga e pode-se usar como referência o modelo de seleção "Hard" e "Soft" discutido por Wallace (1967).

Observando os dados da Tabela 4, é possivel que um agricultor queira abrir uma roça 10 vezes maior que uma roça que possui num dado momento. Imaginando que a roça fornecedora de manivas seja composta de 1000 indivíduos, sendo 500 de uma etnovariedade A e 500 de outra etnovariedade B, a nova roça deve conter 10000 individuos. Se o valor reprodutivo de uma etnovariedade $A$ for 8 e da outra, etnovariedade $\mathrm{B}$, for 15 , quando for montar a nova roça o agricultor conseguirá obter no máximo 4000 plantas de $\mathrm{A}$ tendo que utilizar indivíduos de $\mathrm{B}$ para completar 10000 plantas, o que vai acarretar uma alteração na proporção de uma etnovariedade em relação à outra. Se inicialmente a relação entre as etnovariedades A e B era de $1: 1$, na nova roça a relação será de 1:1,5, caracterizando um processo seletivo, o qual foi causado simplesmente pelo fato de uma etnovariedade ter maior capacidade reprodutiva que a outra.

A situação apresentada acima deve ter sido muito comum quando a cultura da mandioca foi introduzida em regiões que não existia anteriormente. Hoje em dia, com a incerteza que aflige os agricultores a respeito da possibilidade de se abrir novas roças, 
verificam-se muitos casos de agricultores que simplesmente abandonaram a atividade. Caso haja uma retomada desta atividade, e, neste caso, a população de mandioca estiver crescendo em termos absolutos, é possível que ocorra seleção natural nos moldes descritos acima.

É importante lembrar que na região de Ubatuba a bacteriose é inexpressiva mesmo em plantas sucetiveis. Na região do planalto paulista, onde a bacteriose é amplamente disseminada, seu efeito deve ser determinante no sucesso reprodutivo de etnovariedades sucetiveis, principalmente porque a bacteriose ataca o sistema vascular, podendo prejudicar a germinação do material de plantio e, portanto, seleção puramente natural pode vir a ser muito mais importante na estrutura genética destas roças.

\subsection{Manutenção de diversidade}

Por que agricultores autóctones mantém diversidade? Esta é uma questão fundamental abordada em diversos trabalhos envolvendo as mais diversas culturas. $\mathrm{O}$ modelo de Bellon (1996) descrito no ítem 2.4 é muito útil para tentar responder a pergunta. Para aplicá-lo é necessário primeiramente caracterizar os agricultores estudados quanto ao seu perfil de interesses.

$\dot{\mathrm{E}}$ notório, principalmente entre os agricultores AG e DF, que todo o esforço produtivo é alocado na produção de farinha de mandioca e banana para o comércio em feiras-livres na cidade de Ubatuba. Os agricultores FA e FO produzem basicamente farinha, porém estão fora do esquema de venda em feira-livre. Vendem parte da produção localmente e consomem outra parte, não tendo um perfil muito claro em relação aos seus objetivos ao cultivar mandioca, sendo um misto de agricultor comercial com agricultor de subsistència. Lembrando que os agricultores FA e FO estão inseridos num contexto de restrição da atividade agricola. Além da mandioca, pode-se encontrar nas roças de FA e FO maracujá, cará e batata-doce. O agricultor AG ainda produz um pouco de feijão, milho, cará, batata-doce, inhame, mamão e abacaxi nos interstícios da cultura da mandioca, principalmente para consumo próprio. O agricultor DF planta milho, cará, 
batata-doce e feijão também para consumo próprio. A semente de milho na região é semente melhorada. Ainda são encontradas raças locais de feijão, como o feijão SerroAzul. Há, portanto, uma certa produção para subsistência entre estes agricultores, a qual deve declinar cada vez mais frente à facilidade com que se compram alimentos em vendas a preços bem atraentes. Todos os agricultores tem muitos filhos, os quais, na sua maioria, estão morando na cidade e exercendo atividade assalariada. Os agricultores DF e AG ainda possuem filhos trabalhando na agricultura, pois ainda existe oportunidade para isso. Já os agricultores FA e FO tem todos os filhos na cidade, pois a agricultura na Fazenda da Caixa tem se tomado cada vez mais restrita.

E dificil fazer uma classificação discreta dos agricultores seguindo a proposta por Bellon (1996). Diante do quadro apresentado acima, os agricultores, principalmente AG e DF, tendem a ser classificados como agricultores comerciais que ainda praticam alguma agricultura de subsistência em diferentes graus. A mandioca, no entanto, é cultivada basicamente para se produzir farinha e ser comercializada. É importante ressaltar que o fato destes agricultores terem sido classificados como agricultores comerciais tem pouca relação com o nível tecnológico que utilizam na sua agricultura. Muitas vezes se associa agricultura comercial com alto nivel tecnológico, o que nem sempre é verdade.

Como estão basicamente voltados para o comércio de farinha, o primeiro interesse que deve ser atendido pelas etnovariedades que possuem é que estas sejam próprias para fazer farinha e que produzam o suficiente. Produção para eles é um fator muito importante na escolha das etnovariedades que cultivam.

Apesar de todos produzirem sua própria farinha com equipamento tradicional, a capacidade de produção é limitada. Além disso, mesmo que esta capacidade não fosse limitada, não é interessante produzir farinha com toda a mandioca de uma roça de uma só vez, visto que o mercado pode não absorver grandes quantidades. Portanto, é de interesse do agricultor, uma vez estabelecida uma roça que vai durar até 5 anos, colhê-la aos poucos. Há uma grande variação entre as etnovariedades com relação ao período ótimo de colheita, embora este período seja relativamente flexível para uma etnovariedade específica. $\mathrm{Na}$ roça DFG, por exemplo, a etnovariedade Paranaense pode 
ser colhida em 6 meses, a Mucaé pode ser colhida até 2 anos, a Maricá até 1,5 anos e as Landis até 5 a 6 anos. Há, inclusive, uma preocupação de se plantar as etnovariedades mais precoces separadamente, provavelmente para facilitar a colheita. $O$ agricultor AG também demonstrou a preocupação de colher a roça aos poucos e também possui etnovariedades que variam em relação ao periodo de colheita. Um agricultor consultado do Camburi também reconhece que Mandioca-Doce colhe-se de 6 a 8 meses, Maricá até 1,5 anos e que Aipi-Preta é mais tardia. Face a recorrência da preocupação de colher a roça aos poucos, fica evidente que manter etnovariedades diferentes com relação ao periodo de colheita é um fator muito importante.

Os agricultores mantém algumas etnovariedades próprias para consumo cozidas, entretanto muitas delas, como a Amarelinha na roça $A G$, Zumira na roça FA e Paranaense nas roças de DF, podem ser utilizadas também para produzir farinha, não havendo necessidade de manter uma etnovariedade exclusivamente para esta forma de consumo.

Finalmente, todos os agricultores tem a preocupação de manter um certo número de etnovariedades em pequenas proporções simplesmente "para não perder a planta", ou seja, como um pequeno banco de germoplasma que pode vir a ser útil algum dia. A utilidade deste banco ficou claramente demonstrada no caso da etnovariedade Maricá, a qual era uma destas etnovariedades mantidas em pequena quantidade pelos agricultores FA e FO e que, devido a uma alteração ambiental, tomou-se dominante. Manter uma reserva de diversidade para que haja possibilidade de seleção parece ser um fator tão importante quanto produção. Isso fica claro analisando o que ocorreu as roças alteradas. Em comparação com as demais roças, realmente houve uma redução brutal da diversidade expressa pelo índice de Shannon-Weaver. Esta redução se deve mais ao fato de que uma etnovariedade predomina em relação às outras, porém, considerando o número de etnovariedades e o número de fenótipos isoenzimáticos, a variação não foi tão drástica. Ao que tudo indica, os agricultores FA e FO insistem em manter o seu banco de germoplasma mesmo havendo poucas chances de que as condições de cultivo se alterem. Ao serem questionados porque mantém este grupo de etnovariedades em pequena 
quantidade, os agricultores FA e FO responderam simplesmente: "para não perder a planta". Ambos demonstraram interesse em receber etnovariedades que já tinham perdido quando foi aventada a possibilidade de que isto ocorresse, assim como o agricultor já citado do Camburi.

Por outro lado, os agricultores FA e FO simplesmente abdicaram da possibilidade de escalonar a colheita porque as etnovariedades, que não a Maricá, não estavam produzindo o suficiente, a ponto de passarem parte do ano sem ter mandioca para fazer farinha, como foi constatado no final de 1997. Isto sugere que há uma hierarquia nestes interesses inerentes ao modelo proposto por Bellon (1996), o que introduz uma certa nào-linearidade ao modelo que é linear. Deste modo, a produção entraria multiplicando alguns interesses como periodo ótimo de colheita tardio e, sendo o escore referente à produçào zero, o escore da etnovariedade se torna zero e esta é simplesmente eliminada ou cultivada apenas como reserva de diversidade.

Outro aspecto da manutenção da diversidade tem relação com a interação genótipo e ambiente, já que o controle ambiental na agricultura autóctone é muito limitado. É reconhecido pelos agricultores interações entre genótipo e variações ambientais previsiveis, principalmente variações muito intensas das características do solo. AG afirmou que Aipi-Rosa responde melhor no morro que à beira-mar e Maricá responde mau no morro e bem a beira-mar. FA disse que Landí e Mucaé são próprias para solo mais fértil. Para FO é melhor cultivar Landí-Galhada (não existe mais) na várzea que no morro e cultivar Mandioca-Doce em solo argiloso do que em solo arenoso. DF considera que Landí-Brava é mais adaptada à várzea e afirma que Landí-Ferro pode ser cultivada em qualquer local. Estes depoimentos indicam que há um certo conhecimento da performance de determinadas etnovariedades em ambientes especificos. Dessa forma, se o agricultor cultiva em diferentes ambientes, possuindo etnovariedades diferencialmente adaptadas a estes ambientes, é interessante manter todo um conjunto de etnovariedades com o objetivo de possibilitar a utilização de etnovariedades adequadas a ambientes especificos. 
Interação entre genótipo e variações ambientais imprevisiveis é reconhecida por todos os agricultores consultados, principalmente pela percepção de que a produção de determinada etnovariedade varia no tempo e no espaço. Alguns afirmam categoricamente que a baixa produção de determinada etnovariedade pode ser compensada pela alta produção de outra etnovariedade, o que caracteriza uma forma de homeostase populacional descrita no ítem 2.10. FO diz, certa vez, ter estabelecido uma roça apenas com uma etnovariedade e sem obtenção de produção, pois as plantas não formaram raiz utilizável, evidenciando o risco de se cultivar apenas poucos genótipos.

Observando o biplot da Figura 2, a grande heterogeneidade dos solos das roças tradicionais mostra que a interação entre genótipos e ambientes imprevisíveis ocorre tambèm numa mesma roça e o plantio de vários genótipos tende a estabilizar a produção também em relação a esta situação.

Um relato curioso foi dado pelo agricultor AG sobre um caso de cooperação entre genótipos, também discutido no ítem 2.10. Segundo ele, plantar a Aipi-Rosa sozinha numa área (não necessariamente em toda uma roça) é desvantajoso pois esta é muito sucetivel ao acamamento. A solução é intercalar individuos de Aipi-Rosa com individuos de outras etnovariedades de modo a se criar uma estrutura que deve minimizar o problema. Isto foi confirmado pelo agricultor FO.

A necessidade de produção comercial, de se escalonar a produção de farinha, o desejo de se manter uma reserva de diversidade e a existência de variações ambientais previsiveis e imprevisiveis podem ser considerados razões fundamentais que justificam a manutenção de diversidade na cultura da mandioca pelos agricultores que tiveram sua agricultura estudada em Ubatuba

\subsection{Erosão genética e política ambiental}

É inegável que erosão genética está ocorrendo na agricultura autóctone em Ubatuba na espécie Manihot esculenta. Erosão genética tem sido atribuída a vários fatores relacionados à capacidade dos melhoristas de produzir cultivares muito melhores 
do que as etnovariedades, os quais as estariam substituindo. O que se vê em Ubatuba não é bem isso. Os agricultores de Ubatuba certamente tiveram acesso a cultivares melhorados, visto que informaram que já tiveram contato com agrônomos da assistência técnica estatal local, os quais tem uma postura de disseminar a agricultura tecnificada, com altos niveis de utilização de insumos e uso de cultivares melhorados adaptados a estas condições. Contudo, as etnovariedades não foram substituídas por cultivares melhorados, provavelmente porque estes cultivares não atenderam a todos os interesses destes agricultores, os quais, além disso, não adotaram o sistema de agricultura proposto pela assistència técnica e devem ter optado por isso por razões bem consistentes, uma vez que a regra na região é agricultura tropical autóctone e não agricultura tecnificada.

$\mathrm{Na}$ verdade, o fator determinante no processo de erosão genética em Ubatuba é a restrição da prática agricola imposta pela politica ambiental estatal e posta em prática com a implantação do Parque Estadual da Serra do Mar, cuja consequeência é a limitação das oportunidades que os agricultores tem de cultivar, selecionar e trocar etnovariedades. $\dot{E}$ curioso que consta dos atributos do parque servir como banco genético tropical. Mesmo assim, a agricultura não foi levada em consideração como fonte de recursos genéticos. A dicotomia natural/artificial foi levada às últimas conseqüências e foi generalizada a tal ponto que um agricultor que derruba uma área para fazer uma roça, o que sempre foi feito na região sem maiores conseqüências ambientais, está sujeito à mesma lei que um empresário responsável pela alteração de uma área para a implantação de um condominio para turistas. Não se teve a sensibilidade de perceber que o Homem poderia ser um forte aliado e fazer parte das estratégias de conservação, visto que está estabelecido na região, praticando agricultura, há séculos, sem que a floresta tropical tenha sido comprometida.

Outra dicotomia que tem sido adotada sob um ponto de vista quase mistico é a que relaciona espécies nativas com exóticas. Que critério tem-se adotado para separar as duas classes ? Seriam espécies domesticadas todas exóticas ? A mandioca, mesmo estando presente na região há mais de 500 anos, deve ser considerada exótica apenas pelo fato de ser cultivada ? E quanto às outras espécies domesticadas? O problema de definir o que é 
uma especie exótica é de extrema relevância pelo fato de que a legislação não permite a presença de qualquer espécie exótica no parque.

Questões como estas tem sido simplesmente ignoradas inclusive por quem faz ciència. Muitos trabalhos tem sido realizados tentando associar a distribuição e abundància de espécies "nativas" a fatores ambientais e interações com outras espécies "nativas". Entretanto, à presença humana, que tem ativamente alterado o ambiente durante séculos, tem sido atribuida uma importância negligenciável quando não é simplesmente ignorada como fator determinante na abundância e distribuição destas espécies.

Um argumento muito utilizado para defender a não permissão de agricultura em àreas protegidas no litoral paulista é a afirmação de que não existe mais uma cultura caiçara. Se isto fosse verdade, a probabilidade de se encontrar uma coerència no sistema de classificação de etnovariedades, nas atitudes e no manejo agricola dos agricultores seria minima, pois nenhum agricultor caiçara é agrônomo e muito menos taxonomista, o que é uma forte evidència de que este conhecimento tem sido transmitido por tradição cultural. Se esta cultura está sendo transmitida para gerações mais novas é outra questão e, isto sim, deveria ser motivo de sérias preocupações e de tomada de atitudes politicas que estimulassem a continuidade de uma cultura tão rica.

Por outro lado, sem alguma política ambiental é provável que as pressões do turismo e da exploração imobiliária tivessem aniquilado completamente a cultura caiçara, como pode ser observado nas áreas ao sul de Ubatuba, onde a cultura caiçara deu lugar a condominios, hotéis, casas e toda infra-estrutura envolvida com turismo.

Obviamente a agricultura não deve ser praticada de modo irrestrito em áreas de conservação e é absolutamente lícito questionar quais seriam os limites desta prática de modo a maximizar a diversidade intra e interespecífica. Trabalhos com esta abordagem começam a aparecer. Piccolo \& Troppmair (1994) por exemplo, em trabalho realizado no núcleo Picinguaba, concluiram que a diversidade biológica tende a ser maximizada em graus intermediários de perturbação. Como agricultura é uma perturbação, é teoricamente possivel a conciliação de agricultura autóctone não só com a conservação 
da diversidade intra-especifica das plantas cultivadas, como também da biodiversidade de maneira geral.

Finalmente, pelo fato de que etnovariedades dependem da agricultura, sua conservação in situ não pode ser realizada através de seu isolamento em reservas biológicas, ao contrário, a conservação in situ só pode ser alcançada encorajando os agricultores a continuar cultivando as etnovariedades (Brush, 1991). 


\section{CONCLUSÕES}

- Há uma coerência entre o sistema taxonòmico local e a classificação fenotípica obtida através de isoenzimas. A acurácia do sistema de taxonomia local varia de agricultor para agricultor.

- A diversidade reconhecida pelos agricultores tende a subestimar a diversidade isoenzimática na maioria dos casos, mas é possivel que em alguns casos isto não ocorra devido ao poder discriminatório dos sistemas isoenzimáticos utilizados.

- A acurácia da taxonomia local tem reflexo na eficiência com que os recursos genéticos são utilizados pelos agricultores.

- O indice de Shannon-Weaver foi eficiente para quantificar a diversidade das roças estudadas tanto para caracteres morfológicos quanto isoenzimáticos.

- Há uma associação positiva entre o grau de diversidade genética expressa pelos indices de Shannon-Weaver para caracteres isoenzimáticos e morfológicos e fertilidade do solo expressa pelos teores de potássio, fósforo e a porcentagem de matéria orgànica nas roças estudadas.

- Nas roças cujo manejo foi considerado tradicional, a diversidade dos caracteres isoenzimáticos e morfológicos estudados se concentra dentro de roça. 
- O grau de consciência em relação às plantas originadas por semente difere de agricultor para agricultor.

- Seleção artificial consciente é uma prática constante entre os agricultores.

- A constatação da existência de banco de sementes de mandioca, de geração de variabilidade genética através da criação de recombinantes originados por sementes e sua incorporação pelos agricultores, de seleção consciente e de diversidade dentro de etnovariedades é consistente com o modelo de dinâmica evolutiva proposto por Cury (1993) e ampliado por Martins ${ }^{10}$.

- Houve uma redução da diversidade genética nas roças de Ubatuba quando o tempo de pousio foi reduzido. Esta redução da diversidade genética foi decorrente da queda de fertilidade do solo, a qual submeteu a população de mandioca a uma pressão de seleção direcional constante, possibilitando a seleção de uma etnovariedade mais adaptada às novas condições ambientais. Portanto, há uma relação entre manejo e diversidade genética da espécie Manihot esculenta na agricultura tropical autóctone.

- Seleção natural pode ocorrer na agricultura tropical autóctone não só em plantas originadas por semente, mas caso haja pressões de seleção muito intensas na roça de mandioca ou caso a população esteja crescendo com taxas relativamente altas em termos absolutos.

- Os agricultores estudados mantém diversidade basicamente para escalonar a produção de farinha através da extensão do período de colheita, como reserva de diversidade para ter a possibilidade de adaptar genótipos específicos a ambientes específicos e para

\footnotetext{
${ }^{10}$ Martins, P.S. (Departamento de Genética da Escola Superior de Agricultura Luiz de Queiroz). Comunicação pessoal, 1996.
} 
manter uma produção relativamente estável frente às incertezas decorrentes da interação entre genótipo e ambientes imprevisíveis.

- O agricultor de Ubatuba também retém intencionalmente um banco de genes como estratégia para enfrentar possíveis alterações ambientais não previsíveis.

- Foi constatada a existência de uma cultura caiçara relacionada à atividade agrícola.

- A política ambiental estatal tem contribuído para a ocorrência de alterações do manejo na agricuttura tropical autóctone em Ubatuba, as quais têm como consequeência básica a redução do tempo de pousio das áreas cultivadas.

- Erosão genética em plantas cultivadas ocorre na Região Norte de Ubatuba como conseqüência indireta da restrição à atividade agrícola imposta pela política ambiental estatal. 


\section{REFERÊNCIAS BIBLIOGRÁFICAS}

ACOSTA-ESPINOSA, J. Variabilidade e associações genéticas entre caracteres de mandioca (Manihot esculenta Crantz) combinando policruzamento e propagação vegetativa. Piracicaba 1984. 118 p. Tese (Doutorado)-Escola Superior de Agricultura "Luiz de Queiroz", Universidade de São Paulo.

ALCORN, J.B. Indigenous agroforestry strategies meeting farmers' needs. In:. ANDERSON, A.B. Alternatives to deforestation: steps toward sustainable use of amazon rainforest. New York: Columbia University Press, 1990. cap.9, p.141-215.

ALFENAS, A.C.; PETERS, I.; BRUNE W.; PASSADOR, G.L. Eletroforese de proteínas e isoenzimas de fungos e essência florestais. Viçosa: UFV/SIF, 1991. $242 \mathrm{p}$.

ALLARD, R.W. Relationship between genetic diversity and consistency of performance in different environments. Crop Science,v.1, p. 127-133, 1961.

ALLARD, R.W.; BRADSHAW, A.D. Implications of genotype-environmental interactions in applied plant breeding. Crop Science, v.4, p.503-508, 1964.

ALTIERI, M.A. El rol ecologico de la biodiversidad en agroecosistemas. Agroecologia e Desarrollo, n.4, p.2-11, 1992. 
ALTIERI, M.A.; ANDERSON, M.K. Peasant farming systems, agricultural modernization, and the conservation of crop genetic resources in Latin America. In: FIEDLER P.L.; JAIN S.K. (Ed.) The theory and practice of nature conservation, preservation and management. New York: Chapman \& Hall, 1992. cap.3, p.49-64.

ARNOLD, S.J.; WADE, M.J. On the measurement of natural and sexual selection: theory. Evolution, v.38, n.4, p.709-710, 1984.

ATAYESE, M.O.; AWOTOYE, O.O.; OSONUBI, O; MULONGOY, K. Comparisons of the influence of vesicular-arbuscular mycorriza on the productivity of hedgerow woody legumes and cassava at the top and the base of a hillslope in alley cropping systems. Biology and Fertility of Soils, v. 16, p. 98-204, 1993.

AWETO, A.O. Effects of shifting cultivation on a tropical forest soil in Southwestern Nigeria. Turrialba, v.38, n. 1, p.19-22, 1988

BARRIGA, R.H.M.P. Caracterização de cultivares de mandioca (Manihot esculenta Crantz) com relação à produção e estabilidade. Piracicaba, 1980.128 p. Dissertação (Mestrado)-Escola Superior de Agricultura "Luiz de Queiroz", Universidade de São Paulo.

BARROS, L.M. Caracterização morfológica e isoenzimática do cajueiro (Anacardium accidentale L.), tipos comum e anão precoce, por meio de técnicas multivariadas. Piracicaba, 1991. 156 p. Tese (Doutorado)-Escola Superior de Agricultura 'Luiz de Queiroz", Universidade de São Paulo. 
BECHERE, E.; BELAY, G.; MITIKU, D.; MERKER, A. Phenotypic diversity of tetraploid wheat landraces from northem and north-central regions of Ethiopia. Hereditas, v. 124, p. 165-172, 1996.

BEGON, M.; HARPER, J.L.; TOWNSEND, C.R. Ecology: individuals, populations and communities. 3.ed. Oxford: Blackwell Science, 1996. 1068 p.

BEKELE, E. Allozyme genotypic composition and genetic distance between the ethiopian land race populations of barley. Hereditas, v.98, p.259-267, 1983.

BEKELE, F.; BEKELE, I. A sampling of the phenetic diversity of cacao in the international cocoa gene bank of Trinidad. Crop Science, v.36, p.57-64, 1996.

BELLON, M.R. The dynamics of crop infraspecific diversity: a conceptual framework at the farmer level. Economic Botany, v.50, n.1, p.26-39, 1996.

BELLON, M. R.; BRUSH, S.B. Keepers of maize in Chiapas, Mexico. Economic Botany, v.48, n.2, p.196-209, 1994.

BENZ, B.F.; SÁNCHES-VELÁSQUES, L.R.; SANTANA MICHEL, F.J. Ecology and ethnobotany of Zea diploperennis: preliminary investigations. Maydica, v.35, p.8598, 1990.

BRASIL. Ministério da Agricuitura. Serviço Nacional de Pesquisas Agronômicas. Comissão de Solos. Boletim 12: levantamento e reconhecimento dos solos do Estado de São Paulo. Rio de Janeiro, 1960. 634p. 
BOSTER, J.S. Classification, cultivation, and selection of Araguaruna cultivars of Monihot esculenta (Euphorbiaceae). Advances in Economic Botany, v.1, p.34-47, 1984.

BOSTER, J.S. Selection for perceptual distinctiveness: evidence from Aguaruna cultivars of Monihot esculenta. Economic Botany, v.39, n.3, p. 310-325, 1985.

BREWER, G.L.; SING, C.F. An introduction to isozyme techniques. New York: Academic Press, 1970. 186p.

BRONDANI, C. Variaçào isoenzimática de três espécies do gênero Manihot (Euphorbiaceae) relacionadas morfologicamente à mandioca (Manihot esculenta Crantz). Pesquisa Agropecuária Brasileira, v.31, n.4, p.287-289, 1996.

BRUSH, S.B. Reconsidering the green revolution: diversity and stability in cradle areas of crop domestication. Human Ecology, v.20, n.2, 1992.

BRUSH, S.B. In situ conservation of landraces in centers of crop diversity. Crop Science, v.35, p.346-354, 1995.

BRUSH, S.B.; CARNEY, H.J.; HUAMÁN, Z. Dynamics of andean potato agriculture. Economic Botany, v.35, p.70-88, 1981.

BRUSH, S.; KESSELI, R.; ORTEGA, R.; CISNEROS, P.; ZIMMERER, K.; QUIROS, C. Potato diversity in the andean center of crop domestication. Conservation Biology, v.9, n.5, p.1189-11 98, 1995.

BRUSH, S.B. A farmer-based approach to conserving crop germplasm. Economic botany, v.45, n.2, p.153-165, 1991. 
CARVALHO, W.A.; PEREIRA, M.A.; PFEIFER, R.M. Fotointerpretação de bacias hidrográficas na discriminação de solos do Parque Estadual da Serra do Mar, Núcleo Picinguaba, SP. Científica, v.20, n.1, p.27-42, 1992.

CASTILLO, R.O. Plant genetic resources in the Andes: Impact, conservation and management. Crop Science, v.35, p.355-360, 1995.

CECCARELLI, S. Adaptation to low/high input cultivation. Euphytica, v.92, p.203214, 1996.

CHAKRABORTY, R.; RAO, C.R. Measurements of genetic variation for evolutionary studies. Handbook of Statistic, v.8, p.271-316, 1991.

CLAYTON, J.W.; TRETIAK, D.N. Amine-citrate buffers for PH control in starch gel eletrophoresis. Journal of the Fisheries Research Board of Canada, v.29, p.1169-1172, 1972.

CLEVELAND, D.A.; SOLERI, D.; SMITH, S.E. Do folk crops have a role in sustainable agriculture? BioScience, v.44, n.11, p.740-751, 1994.

COHEN, J.I.; ALCORN, J.B.; POTTER, C.S. Utilization and conservation of genetic resources: international projects for sustainable agriculture. Economic Botany, v.45, n.2, p.190-199, 1991.

CONSOLI, L. Análise genética e molecular da variação somaclonal em Stylosanthes grianensis (Aubl.) SW (Leguminosae). Piracicaba, 1995. 108p. Dissertação (Mestrado). Escola Superior de Agricultura "Luiz de Queiroz", Universidade de São Paulo. 
CROW, J.F.; KIMURA, M. An introduction to population genetic theory. New York: Harper \& Row, 1970. 591p.

CUEVAS-PÉREZ, F.E.; GUIMARÃES, E.P.; BERRÍO, L.E.; GONZÁLEZ, D.I. Plant genetic resources: genetic base of irrigated rice in Latin America and Caribean, 1971 to 1989. Crop Science, v.32, p. 1054-1059, 1992.

CURY, R. Dinàmica evolutiva e caracterização de germoplasma de mandioca (Manihot esculenta Crantz) na agricultura autóctone do sul do Estado de São Paulo. Piracicaba, 1993. 103 p. Dissertação (Mestrado)-Escola Superior de Agricultura "Luiz de Queiroz", Universidade de São Paulo.

DI RENZO, M.A; AIASSA, D.E.; IBAÑEZ, M.A. Distribuición de la variabilidad en cinco cultivarez de centeno (Secale cereale L.). Turrialba, v.41, n.3, p.325-329, 1991.

DOBZHANSKY, T. Adaptedness and fitness. In: LEWONTIN, R.C. Population biology and evolution. New York: Syracuse University Press, 1967. cap.8, p.109121.

DOMINGUEZ, C.E.; CEBALLOS, L.F.; FUENTES, C. Morfologia de la planta de yuca. In: DOMINGUEZ, C.E. Yuca: investigacion, producion y utilizacion. Cali: CIAT, 1984. p.29-49.

EDEN. M.J. Crop diversity in tropical swidden cultivation: comparative data from Colombia and Papua New Guinea. Agriculture, Ecosystems and Environment, v.20, p.127-136, 1988. 
EDEN, M.J. Swidden cultivation in forest and savanna in lowland southwest Papua New Guinea. Human Ecology, v.21, n.2, p. 127-136, 1993.

ENGELS, J.M.M. Genetic diversity in ethiopian barley in relation to altitude. Genetic Resources and Crop Evolution, v.41, p.67-73, 1994.

EZETA, F.N.; CARVALHO, P.C.L. Influência da endomicorriza na absorção de P e K no crescimento da mandioca. Revista Brasileira de Ciência do Solo, v.6, p.25-28, 1982.

FARALDO, M.I.F. Caracterização isoenzimática e diversidade de etnovariedades de mandioca (Momihot esculenta Crantz). Piracicaba, 1995. 91p. Dissertação (Mestrado)-Escola Superior de Agricultura 'Luiz de Queiroz", Universidade de São Paulo.

FELSENSTEIN, J. The theoretical population genetics of variable selection and migration. Annual Review of Genetics, v. 10, p.253-280, 1976.

FISHER, R.A. The general theory of natural selection. 2. ed. New York: Dover Publications, 1958. $291 \mathrm{p}$.

FRANKEL, O.H. Genetic conservation in perspective. In FRANKEL, O. H.; BENNETT, E. (Ed.). Genetic resources in plants: their exploration and conservation. Oxford: Blackwell ScientificPublishing, 1970. p.469-488. (IBP Handbook 11).

FUNK, C.R.; ANDERSON, J.C. Performance of mixtures of field corn (Zea mays L.) hybrids. Crop Science, v.4, p.353-356, 1964. 
FUTUYMA D.J. Biologia evolutiva. 2.ed. Ribeirão Preto: SBG, 1992. 631 p.

GEPTS, P; DEBOUCK, D. Origin, domestication, and evolution of the commom bean (Phaseolus vulgaris L.) In: SCHOONHOVEN, A.; VOYSEST, O. (Ed.) Commom beans: research for crop improvement. CAB International, 1991. cap 1, p. 7-53.

GRANER E.A. Polyploid cassava: induced by colchicine treatment. Journal of Heredity, v.32, p.281-288, 1941.

GRANER E.A. Genetica de Manihot. I. Hereditariedade da forma da folha e da coloraçào da pelicula externa das raizes em Manihot utilissimum Pohl. Bragantia, v.2, p. 13-22, 1942a.

GRANER E.A. Notas sobre o florescimento e frutificação da mandioca. Bragantia, v.2, n. 1, p. 1-12, 1942b.

GRANT, V. The evolutionary process: a critical review of evolutionary theory. New York: Columbia University Press, 1985. 499p.

GULICK, P.; HERSHEY, C; ALCAZAR, J.E. Genetic resources of cassava and wild relatives. Rome: International Board for Plant Genetic Resources (IBPGR), 1983. $56 \mathrm{p}$.

HALDANE, J.B.S.; JAYAKAR, S.D. Polymorphism due to selection of varying direction. Journal of Genetics, v.58, p.237-242, 1962.

HAMES, R. Monoculture, polyculture, and polyvariety in tropical forest swidden cultivation. Human Ecology, v. 11, n. 1, p. 13-34, 1983. 
HAMRICK, J.L.; GODT, J. W. Allozyme diversity in plant species. In: SOLTIS, D.E.; SOLTIS, P.S. Isozymes in plant biology. Portland: Discorides Press, 1989. p.4363.

KARLAN, J.G. Crops and man. Madison: American Society of Agronomy. 1975. $295 p$.

HARTL, D.L.; CLARCK, A.G. Principles of population genetics. 2.ed. Sunderland: Sinauer Associates, 1989. 682p.

HAWKES, J.G. The diversity of crop plants. Cambridge: Harward University Press, 1983.

HAWKES, J.G. Centros de diversidad genética vegetal en Latinoamérica. Diversity, v.7, n. 1/2, p.7-9, 1991

HEDRICK, P.W; GNEVAN, M.E.; EWING, E.P. Genetic polymorphism in heterogeneous environments. Annual Review of Ecology and Systematics, v.7, p.1-32, 1976.

HEDRICK, P.W. Genetic polymorphism in heterogeneous environments: a decade later. Annual Review of Ecology and Systematics, v.17, p.535-566, 1986.

HENNINK, S.; ZEVEN, A.C. The interpretation of Nei and Shannon-Weaver within population variation indices. Euphytica, v.51, p.235-240, 1991.

HERSHEY, C.; OCAMPO, N. Yuca-Boletin informativo, v.13, n.1 p.1-5, 1989. 
HERSHEY, C; AMAYA, A. Genética, citogenética, estrutura floral y tecnica de hibridacion de la yuca. In: DOMINGUEZ, C.E. Yuca: investigaion, producion y utilizacion. Cali: CIAT, 1984. p.113-25.

HOWELER, R.H. Long term effect of cassava cultivation on soil productivity. Field Crops Research, v.26, p.1-18, 1991.

IBAÑEZ, M.A.; DI RENZO, M.A.;; POVERENE, M.M.. Isozyme diversity among and within peach groups: freestone, clingstone and nectarines. Scientia Hoticulturae, v.53, p.281-288, 1993.

IGLESIAS, C.A.; CALLE, F.; HERSHEY, C.; JARAMILLO, G.; MESA, E. Sensitivity of cassava (Manihot esculenta Crantz) clones to environmental changes. Field Crops Research, v.36, p.213-220, 1994a.

IGLESIAS, C.; HERSHEY, C.; CALLE, F.; BOLAÑOS, A. Propagating cassava (Manihot esculenta) by sexual seed. Experimental Agriculture, v. 30, p.283-290, 1994b.

JAIN, S.K.; QUALSET, C.O.; BHATT, G.M.; WU, K.K. Geographical patterns of phenotypic diversity in a world collection of drurum wheats. Crop Science, v.15, p. $700-704,1975$.

JENNINGS, D.L. Cassava. In: SIMMONDS, N. W. Evolution of crop plants. London: Longman, 1979. p 81-84.

JOHANNESSEN, C.L. Domestication process of maize continues in Guatemala. Economic Botany, v.36, n. 1, p.84-99, 1982. 
JOHNS, T.; KEEN, S.L. Ongoing evolution of the potato on the altiplano of eastern Bolivia. Economic Botany, v.40, n.4, p.409-424, 1986.

KAWANO, K. Mejoramento genetico de yuca para produtividad. In: DOMINGUEZ, C.E. Yuca: investigacion producion y utilizacion. Cali: CIAT, p. 91-111, 1984.

KAWANO, K.; FUKUDA, W.M.G.; CENPUKDEE, U. Genetic and environmental effects on dry matter of cassava root. Crop Science, v.27, p. 69-74, 1987.

KANG, B.T.; MOORMANN, F.R. Effect of some biological factors on soil variability in the tropics. Plant and Soil, v.47, p.441-449, 1977.

KERR, W.E.; CLEMENT, C.R. Práticas agrícolas de conseqüèncias genéticas que possibilitaram aos indios da Amazônia uma melhor adaptação às condições ecológicas da região. Acta Amazônica, v.10, n.2, p.251-261, 1980.

KERR, W.E.; POSEY, D.A. Informações adicionais sobre a agricultura dos Kayapós. Interciência, v.9, n.6, p.392-397, 1984.

KIMMERER W.J. Diversity/stability: a criticism. Ecology, v.65, n.6, p.1936-1938, 1984.

KIMURA, M. On the change of population fitness by natural selection. Heredity. v.12, n.2, p. 145-167, 1958.

KUMADA, K; OHTA, S.; ARAI, S.; KITAMURA, M.; MMA, K. Changes in soil organic matter and nitrogen fertility during the slash-and-burn and cropping phases in experimental shifting cultivation. Soil Science and Plant Nutrition, v.31, n.4, p.611-623, 1985. 
LANCASTER, P.A; INGRAN, J.S.; LIM, M.Y; COURSEY, D.G. Traditional cassavabased foods: survey of processing techniques. Economic Botany. v.36, n. 1, p.1245, 1982.

LANDE, R., ARNOLD S.J. The measurement of selection on correlated characters. Evolution, v.37, n.6, p.1210-1226, 1983.

LEFFERE, F.; CHARRIER, A. Isozyme diversity within african Manihot germplasm. Euphytica, v.66, p. 73-80, 1993a.

LEFEVRE, F.; CHARRIER, A. Heredity of seventeen isozyme loci in cassava (Manihot esculenta Crantz). Euphytica, v.66, p.171-178, 1993b.

LEITÃO FILHO, H.F. Caracterização botânica de cultivares de mandioca (Manihot esculenta Crantz). O Agronômico, v.29, p.73-81, 1971.

LESSA, A.S.N.; ANDERSON, D.W.; MOIR, J.O. Fine root mineralization, soil organic matter and exchangeable cation dynamics in slash and burn agriculture in the semiarid northeast of Brazil. Agriculture, Ecosystems and Environment, v.59, p.191202, 1996.

LEVENE, H. Genetic equilibrium when more than one ecological niche is available. American Naturalist, v.87, p.331-333, 1953.

LEWONTIN, R.C. The units of selection. Annual Review of Ecology and Systematics, v.1, p.1-18, 1970. 
LEWONTIN, R.C. The genetic basis of evolutionary change. New York: Columbia University Press, 1974. 346 p.

LI, Y.; WU, S.; CAO, Y.; ZHANG, X. A phenotypic diversity analysis of foxtail millet (Setaria italica (L.) P. Beauv.) landraces of chinese origin. Genetic Resources and Crop Evolution, v.43, p.377-384, 1996.

LORENZI, J.O.; GALLO, J.R.; MALAVOLTA, E. Exigências de macronutrientes de dois cultivares de mandioca (Manihot esculenta Crantz). Anais da ESALQ, v.37, p. $443-462,1980$.

MACGRAW, J.B.; CASWELL, H. Estimation of individual fitness from life-history data. The American Naturalist, v. 147, n.1, p.47-64, 1996.

MANLY, B.F.J. Multivariate statistical methods: a primer. London: Chapman \& Hall, 1994. $215 \mathrm{p}$.

MARTINS, P.S. Biodiversity and agriculture: patterns of domestication of brazilian native plants species. Anais da Academia Brasileira de Ciências, v.66, p.219-224, 1994.

MAURICIO, R; MOJONNIER L.E. Reducing bias in the measurement of selection. Trends in Ecology and Evolution, v. 12, n. 11, p.433-436, 1997.

MAZZARINO, M; EWEL, J.; BERISH, C.; BROWN, B. Efectos de una sucesion de cultivos en la fertilidade de suelos volcanicos respecto a la sucesión natural. Turrialba, v.38, n.4, p.345-351, 1988. 
MELO NETO, J.E. Implantação e manejo do Núcleo Picinguaba do P. E. da Serra do Mar. Revista do Instituto Florestal, v.4, p.886-887, 1992

MILLAR, C.I. The califomian closed cone pines (Subsection Oocarpae little and Critchfield): a taxonomic history and review. Taxon, v.35, n.4, p. 647-656, 1986.

MOTA, I.S.; NOFFS, M.S. Danos ambientais na mata atlântica, setor São SebastiãoUbatuba, SP, identificados a partir do núcleo Caraguatatuba do Parque Estadual da Serra do Mar. Revista do Instituto Florestal, v.4, p.855-859, 1992

NASSAR, N.M.A. Broadening the genetic base of cassava, Manihot esculenta Crantz, by interspecific hybridization. Canadian Journal of Plant Science, v.69, n.3, p. 1071-1073, 1989. Resumo CAB Abstracts 1990-1991.

NYE, M.M. The mis-measure of manioc (Manihot esculenta, Euphorbiaceae). Economic Botany, v. 45, n. 1, p.47-57, 1991.

ODUM, E.P. Ecology. London: Holt, Rinehart and Winston, 1975. 244 p.

OKA, H.I. The possible role of genetic diversity in integrated pest control. In: MOTOOKA, P.S. (Ed.). Planing workshop on cooperative field research in pest management. Honolulu: East-West Institute Proceedings, 1975. p 24-35.

OKA, H.I. The use of genetic diversity in managing agro-ecosytems. Reprinted from Proceedings of the Plant Breeding Symposium, 1982. p.25-42.

OKA, H. I. Origin of cultivated rice. Amsterdan: Japan Scientific Societies Press, 1988. 254p. 
PAPY, L. Ȧ margem do império do café: a fachada atlântica de São Paulo. Boletim Geográfico, v.15, p.139-165, 1957

PATANOTHAI, A.; ATKINS, R.E. Yield stability of single crosses and three-way hybrids of grain sorghum. Crop Science, v. 14, p.287-290, 1974.

PELLET, D.; EL-SHARKAWY, M.A. Cassava varietal response to phosphorus fertilization. I. Yield, biomass and gas exchange. Field Crops Research, v. 35, p.111, 1993a.

PELLET, D.; EL-SHARKAWY, M.A. Cassava varietal response to phosphorus fertilization. II. Phosphorus uptake and use efficiency. Field Crops Research, v.35, p.13-20, 1993b.

PEREIRA, A.V.; VENCOVSKY, R.; CRUZ, C.D. Selection of botanical and agronomical descriptors for the characterization of cassava (Manihot esculenta Crants) Germplasm. Revista Brasileira de Genética, v.15, n.1, p.115-124, 1992.

PICCOLO, P.R.; TROPPMAIR, H. Ensaio metodológico visando a inserção da biodiversidade no planejamento geoambiental: estudo de caso Picinguaba (Parque Estadual da Serra do Mar), SP. Geografia, v.19, n.2, p.113-129, 1994.

PLARRE, W. Evolution and variability of special cultivated crops in the highlands of West New Guinea (Irian Jaya) under present neolithic conditions. Plant Genetic Resources Newsletter, v. 103, p. 1-13, 1995. 
POSEY, D.A. Manejo da floresta secundária, capoeiras, campos e cerrados (Kayapó). In: Ribeiro, D. (Ed). Suma etnológica brasileira. 2.ed. Petrópolis: Vozes, 1987, v. 1, cap.11, p. 173-185.

PRICE, S.C.; SHUMAKER, K.M.; KAHLER, A.L.; ALLARD, R.W.; HILL J.C. Estimates of population differentiation obtained from enzyme polymorphisms and quantitative characters. The Journal of Heredity, v.75, p. 141-142, 1984.

PROBST, A.H. Performance of variety blends in soybeans. Agronomy Journal, v.49, p.148-150, 1957.

PROJETO RADAMBRASIL. Folhas SF, 23/24. Rio de Janeiro/Vitória: Geologia, geomorfologia, pedologia, vegetação e uso potencial da terra. Rio de Janeiro, v.32. 1983. 780 p. (Levantamento de Recursos Naturais)

PUECHER, D.J.; IBAÑEZ, M.A.; DI RENZO, M.A. Classification and diversity values of seventeen cultivars of Eragrostis curvula. Seed Science and Technology, v.24, p.139-149, 1996.

QUIROS, C.F.; BRUSH, S.B.; DOUCHES, D.S.; ZIMMERER, K.S.; HUESTIS, G. Biochemical and folk assessment of variability of andean cultivated potatoes. Economic Botany, v.44, n.2, p.254-266, 1990.

RAIJ, B.V. et al. Boletim técnico n.100: Recomendações de adubação e calagem para o Estado de São Paulo. 2.ed. Campinas: Instituto Agronômico \& Fundação IAC, 1996.

RAYNOR, B; LORENS, A.; PHILLIP, J. Traditional Yam cultivation on Pohnpei, Easterm Caroline Islands, Micronesia. Economic Botany, v.46, n.1, p.25-33, 1992. 
REICH, V.H.; ATKNS, R.E. Yield stability of four population types of grain sorghum, Sorghum bicolor (L.) Moench, in different environments. Crop Science, v.10, p.511-517, 1970.

RODRIGUEZ, E.P.F. Comunidades tradicionais do Núcleo Picinguaba-bairro de Cambury. In: CONGRESSO BRASILEIRO DE ANÁLISE AMBIENTAL. FÓRUM NACIONAL, 1., Rio Claro, 1994. Política Ambiental para o Próximo Governo; Resumos expandidos. Rio Claro: UNESP, 1994. p.21-24.

ROGERS, D.J. Some further considerations on the origin of Manihot esculenta Crantz. Tropical Root and Tuber Crops Newsletter, v.6, p.4-10, 1972.

ROGERS, D.J.; APPAN, S.G. Manihot and manihotoides (Euphorbiaceae). Flora Neotropica. Monograf., 1973, n.13. 272 p.

ROSSATO, S.C. Utilização de plantas por populações do litoral norte do Estado de São Paulo. São Paulo, 1996. 119p. Dissertação (Mestrado). Departamento de Ecologia Geral do Instituto de Biociências, Universidade de São Paulo.

ROSSI, M.; PFEIFER, R.M. Pedologia do Parque Estadual da Serra do Mar I: levantamento e reconhecimento dos solos. Revista do Instituto Florestal, v.3, n. l, p.1-44, 1991.

ROWE, P.R.; ANDREW, R.H. Phenotypic stability for a systematic series of corn genotypes. Crop Science, v.4, p. 563-567, 1964. 
ROUSI, A.; JOKELA, P.; KALLIOLA, R.; PIETILÄ L.; SALO, J.; YLI-REKOLA, M. Morphlogical variation among clones of ulluco (Ullucus tuberosus, Basellaceae) collected in southern Peru. Economic Botany, v.43, n.1, p.58-72, 1989.

SALICK, J. Crop domestication and evolutionary ecology of cocona (Solanum sessiliflorum Dunal). In: HECHT, M.K et al.(Ed.) Evolutionary biology. New York: Plenum Press, 1992. p. 247-285.

SALICK, J. Toward an integration of evolutionary ecology and economic botany: personal perspectives on plant/people interactions. Annals of the Missouri Botanical Garden, v.82, p.25-33, 1995.

SALICK, J; CELLINESE, N.; KNAPP, S. Indigenous diversity of cassava: generation, maintainance, use and loss among Amuesha, peruvian upper Amazon. Economic Botany, v. 51, n.1, p.6-19, 1997.

SAUER, J. Agricultural origin and dispersals. New York: American Geographyc Society, 1952.

SCANDALIOS, J.G. Genetic control of multiple molecular forms of enzymes in plants: a review. Biochemical Genetics, v.3, p.37-39, 1969.

SCHMIDT, C.B. A mandioca: contribuição para o conhecimento de sua origem. Boletim da Agricultura, v.25, p.73-128, 1951.

SCHMIDT, C.B. Lavoura caiçara. Rio de Janeiro: Ministério da Agricultura / Serviço de Informação Agricola, 1958. 79p. (Documentário da Vida Rural, 14). 
SILVA, S.O. Instalação e caracterização botânico-agronômica de coleções de mandioca. Cruz das Almas: EMBRAPA/CNPMF, 1981. 51p.

SOLERI, D.; CLEVELAND, D.A. Hopi crop diversity and change. Journal of Ethnobiology, v.13, n.2, p.203-231, 1993.

SOLERI, D.; SMITH, S.E. Morphological and phenological comparissons of two Hopi maize varieties conserved in situ and ex situ. Economic Botany, v.49, n. 1, p.56-77, 1995.

STRATTON, D.A. Life-cicle components of selection in Erigeron ammuus:II. Genetic variation. Evolution, v.46, n. 1, p. 107-120, 1992.

UHL, C; MURPHY, P. A comparison of productivities and energy values between slash and burn agriculture and secondary succession in the upper Rio Negro region of the Amazon basin. Agro-Ecosystems, v.7, p.63-83, 1981.

VICKERS, W.T. Tropical forest mimicry in swiddens: a reassessment of Geertz's model with amazonian data. Human Ecology, v. 1 1, n. 1, p.35-45, 1983.

VIEGAS, A.V. Estudos sobre mandioca. Campinas: IAC/BRASCAN NORDESTE, 1976. 214 p.

WALLACE, B. Polymorphism, population size, and genetic load. In: LEWONTIN, R.C. (Ed.). Population biology and evolution. New York: Syracuse University Press, 1967. cap.7, p.87-108.

WEIR, B.S. Genetic data analysis II: methods for discrete population genetic data. Sunderland: Sinauer Associates, 1996. 445 p. 
WEST-EBERHARD, M.J. Adaptation: current usages. In: KELLER, E.F.; LLOYD, E.A. Keywords in evolutionary biology. Cambridge: Harvard University Press, 1994. p.13-18.

XOLOCOTZI, E.H. Maize and man in the greater southwest. Economic Botany, v.39, n. 4, p. $416-430,1985$.

ZIMMERER, K.S.; DOUCHES, D.S. Geographical approaches to crop conservation: the partitioning of genetic diversity in andean potatoes. Economic Botany, v.45, n.2, p.176-189, 1991. 
APÊNDICE 
Apêndice 1- Dados de fertilidade de solo originais. Pres em ppm, $\mathrm{MO}$ em \%, $\mathrm{pH}$ e os demais elementos em meq / 100g.

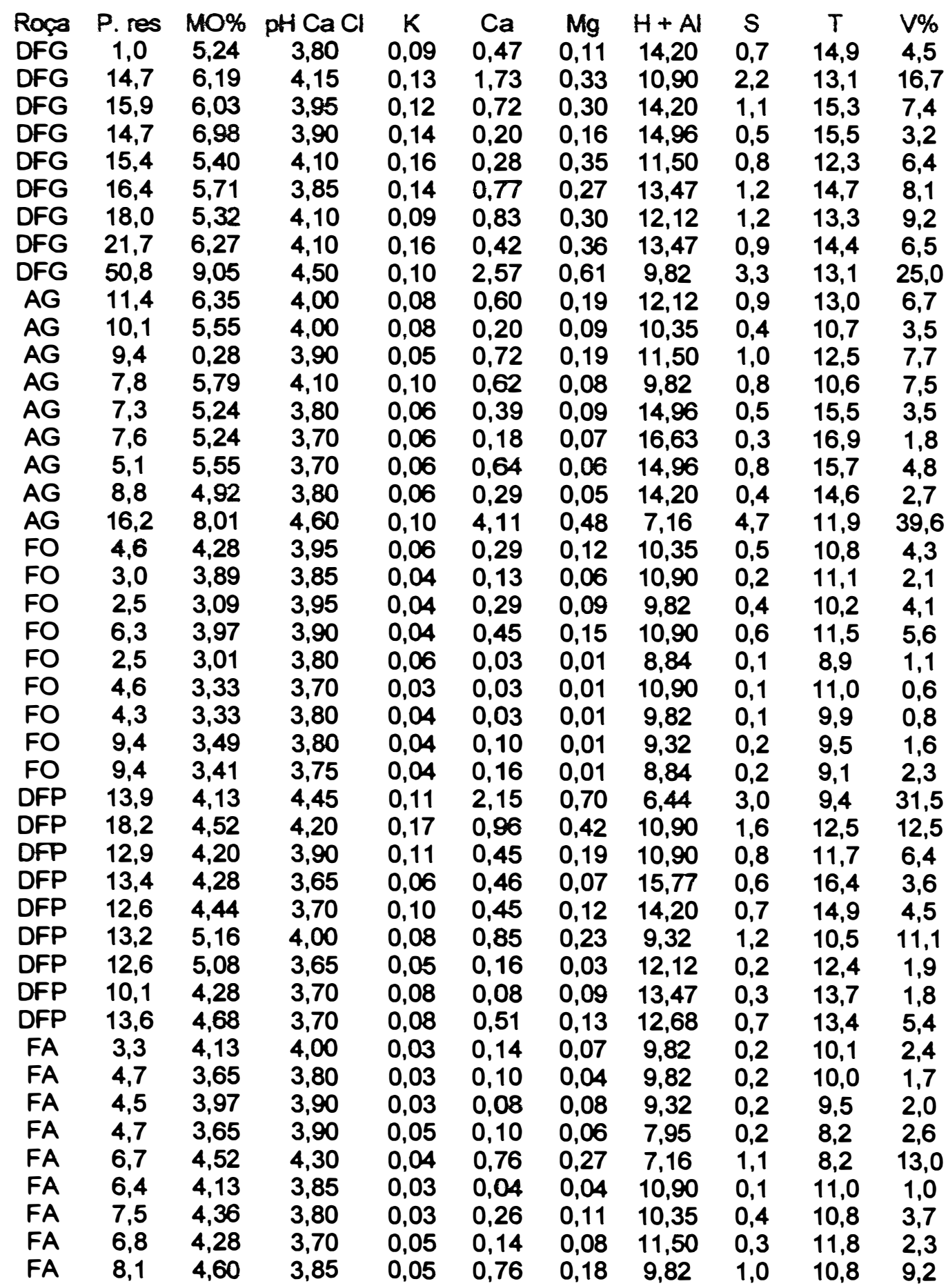


Apèndice 2- Dados originais de isoenzimas da roça $A G$.

\begin{tabular}{|c|c|c|c|c|c|c|c|c|c|c|c|c|c|}
\hline Indiv. & MDH 1 & MDH 2 & MDH 3 & $\mathrm{MDH} 4$ & $4 \mathrm{MDH} 5$ & MDH 6 & $\mathrm{MDH} 7$ & MDH 8 & SK 1 & SK 2 & SK 3 & SK 4 & SK 5 \\
\hline AM & 0 & 1 & 0 & 0 & 1 & 1 & $i$ & 1 & 0 & 1 & 0 & 1 & 0 \\
\hline$\tilde{z}$ & 0 & 1 & 0 & 0 & 1 & 1 & 1 & 1 & 0 & 0 & 1 & 0 & 1 \\
\hline 21 & 0 & 1 & 0 & 0 & 1 & 1 & 1 & 1 & 0 & 0 & 0 & 1 & 0 \\
\hline LA & 0 & 1 & 0 & 0 & 1 & 1 & 1 & 1 & 0 & 0 & 0 & 1 & 0 \\
\hline$\hat{A R}$ & 0 & 1 & 0 & 0 & 1 & 1 & $i$ & $i$ & 0 & 0 & 1 & 0 & $\mathrm{i}$ \\
\hline MT & 1 & 0 & 1 & 1 & 1 & 1 & 1 & 1 & 0 & 0 & 0 & 1 & 0 \\
\hline AR & 0 & 1 & 0 & 0 & 1 & 1 & 1 & 1 & 0 & 0 & 0 & 1 & 0 \\
\hline LA & 0 & 1 & 0 & 0 & 1 & 1 & 1 & 1 & 0 & 0 & 0 & 1 & 0 \\
\hline MO & 0 & 1 & 0 & 0 & $i$ & $i$ & 1 & 1 & 0 & 0 & 1 & 0 & 1 \\
\hline MT & 1 & 0 & 1 & 1 & 1 & 1 & 1 & 1 & 0 & 0 & 0 & 1 & 0 \\
\hline AR & 0 & 1 & 0 & 0 & 1 & 1 & 1 & 1 & 0 & 0 & 0 & 1 & 0 \\
\hline LA & 0 & 1 & 0 & 0 & 1 & 1 & 1 & 1 & 0 & 0 & 0 & 1 & 0 \\
\hline AR & 0 & 1 & 0 & 0 & 1 & $i$ & $i$ & $i$ & 0 & 0 & 0 & $i$ & 0 \\
\hline LD & 0 & 1 & 0 & 0 & 1 & 1 & 1 & 1 & 0 & 1 & 0 & 1 & 0 \\
\hline AR & 0 & 1 & 0 & 0 & 1 & 1 & 1 & 1 & 0 & 0 & 0 & 1 & 0 \\
\hline 21 & 0 & 1 & 0 & 0 & 1 & 1 & 1 & 1 & 0 & 0 & 0 & 1 & 0 \\
\hline $2 \mathrm{i}$ & 0 & $i$ & 0 & 0 & $i$ & $i$ & $i$ & $i$ & 0 & 0 & 0 & 1 & 0 \\
\hline 21 & 0 & 1 & 0 & 0 & 1 & 1 & 1 & 1 & 0 & 0 & 0 & 1 & 0 \\
\hline$L A$ & 0 & 1 & 0 & 0 & 1 & 1 & 1 & 1 & 0 & 0 & 1 & 0 & 1 \\
\hline 21 & 0 & 1 & 0 & 0 & 1 & 1 & 1 & 1 & 0 & 0 & 0 & 1 & 0 \\
\hline$\overline{A R}$ & 0 & $i$ & 0 & 0 & $i$ & $i$ & $i$ & $i$ & 0 & 0 & 0 & 1 & 0 \\
\hline LA & 0 & 1 & 0 & 0 & 1 & 1 & 1 & 1 & 0 & 0 & 0 & 1 & 0 \\
\hline RP & 1 & 0 & 1 & 1 & 1 & 1 & 1 & 1 & 1 & 0 & 0 & 0 & 1 \\
\hline 21 & 0 & 1 & 0 & 0 & 1 & 1 & 1 & 1 & 0 & 0 & 1 & 0 & 1 \\
\hline$\dot{A M}$ & 0 & 1 & 0 & 0 & $i$ & $i$ & $i$ & 1 & 0 & 1 & 0 & 1 & 0 \\
\hline 21 & 0 & 1 & 0 & 0 & 1 & 1 & 1 & 1 & 0 & 0 & 1 & 0 & 1 \\
\hline$\overline{A M}$ & 0 & 1 & 0 & 0 & 1 & 1 & 1 & 1 & 0 & 1 & 0 & 1 & 0 \\
\hline 21 & 0 & 1 & 0 & 0 & 1 & 1 & 1 & 1 & 0 & 0 & 1 & 0 & 1 \\
\hline$A R$ & 0 & 1 & 0 & 0 & $i$ & 1 & $i$ & $i$ & $\hat{0}$ & 0 & 0 & 1 & 0 \\
\hline AR & 0 & 1 & 0 & 0 & 1 & 1 & 1 & 1 & 0 & 0 & 0 & 1 & 0 \\
\hline 21 & 0 & 1 & 0 & 0 & 1 & 1 & 1 & 1 & 0 & 0 & 1 & 0 & 1 \\
\hline 21 & 0 & 1 & 0 & 0 & 1 & 1 & 1 & 1 & 0 & 0 & 1 & 0 & 1 \\
\hline $2 \mathrm{i}$ & 0 & $i$ & 0 & 0 & 1 & 1 & $i$ & $i$ & 0 & 0 & $i$ & 0 & $i$ \\
\hline$\angle A$ & 0 & 1 & 0 & 0 & 1 & 1 & 1 & 1 & 0 & 0 & 1 & 0 & 1 \\
\hline AR & 0 & 1 & 0 & 0 & 1 & 1 & 1 & 1 & 0 & 0 & 0 & 1 & 0 \\
\hline RP & 1 & 0 & 1 & 1 & 1 & 1 & 1 & 1 & 1 & 0 & 0 & 0 & 1 \\
\hline $2 i$ & 0 & 1 & 0 & 0 & 1 & 1 & $i$ & $i$ & 0 & 0 & 1 & 0 & $i$ \\
\hline MT & 1 & 0 & 1 & 1 & 1 & 1 & 1 & 1 & 0 & 0 & 0 & 1 & 0 \\
\hline 21 & 0 & 1 & 0 & 0 & 1 & 1 & 1 & 1 & 0 & 0 & 1 & 0 & 1 \\
\hline 21 & 0 & 1 & 0 & 0 & 1 & 1 & 1 & 1 & 0 & 0 & 1 & 0 & 1 \\
\hline 21 & 0 & $i$ & 0 & 0 & $i$ & $i$ & $i$ & $i$ & 0 & 0 & $i$ & 0 & $i$ \\
\hline 21 & 0 & 1 & 0 & 0 & 1 & 1 & 1 & 1 & 0 & 0 & 1 & 0 & 1 \\
\hline RP & 1 & 0 & 1 & 1 & 1 & 1 & 1 & 1 & 1 & 0 & 0 & 0 & 1 \\
\hline RP & 1 & 0 & 1 & 1 & 1 & 1 & 1 & 1 & 1 & 0 & 0 & 0 & 1 \\
\hline $2 i$ & 0 & 1 & 0 & 0 & $i$ & 1 & $i$ & $i$ & 0 & 0 & $i$ & 0 & $i$ \\
\hline AM & 0 & 1 & 0 & 0 & 1 & 1 & 1 & 1 & 0 & 1 & 0 & 1 & 0 \\
\hline AM & 0 & 1 & 0 & 0 & 1 & 1 & 1 & 1 & 0 & 1 & 0 & 1 & 0 \\
\hline 21 & 0 & 1 & 0 & 0 & 1 & 1 & 1 & 1 & 0 & 0 & 0 & 1 & 0 \\
\hline$R P$ & 1 & 0 & 1 & 1 & $i$ & $i$ & 1 & $i$ & 1 & 0 & 0 & 0 & $i$ \\
\hline$A M$ & 0 & 1 & 0 & 0 & 1 & 1 & 1 & 1 & 0 & 1 & 0 & 1 & 0 \\
\hline 21 & 0 & 1 & 0 & 0 & 1 & $i$ & 1 & 1 & 0 & 0 & 0 & 1 & 0 \\
\hline AM & 0 & 1 & 0 & 0 & 1 & $i$ & 1 & 1 & 0 & 1 & 0 & 1 & 0 \\
\hline
\end{tabular}


Apèndice 2- Dados originais de isoenzimas da roça $\dot{A G}$.

\begin{tabular}{|c|c|c|c|c|c|c|c|c|c|c|c|}
\hline indiv. & PGI 1 & PGI 2 & PGI 3 & PGI 4 & PGI 5 & PGI6 & PGI 7 & LAP 1 & LAP 2 & LAP 3 & LAP 4 \\
\hline$A M$ & 1 & 1 & 1 & 0 & 1 & 1 & 0 & 1 & 0 & 1 & 1 \\
\hline $2 i$ & 1 & 1 & $i$ & 0 & $\mathbf{i}$ & i & 0 & 1 & 0 & $i$ & 1 \\
\hline 24 & 1 & 1 & $i$ & 1 & 0 & 0 & 0 & 1 & 1 & 0 & 1 \\
\hline UA & 1 & 1 & 1 & 0 & 1 & 1 & 0 & 1 & 1 & 0 & 1 \\
\hline AR & 1 & 1 & 1 & 1 & 0 & 0 & 0 & i & 0 & 1 & 1 \\
\hline MT & 1 & $i$ & 1 & 0 & i & $i$ & $i$ & $i$ & 1 & 0 & $i$ \\
\hline$A R$ & $\uparrow$ & 1 & 1 & 0 & 1 & 1 & 0 & 1 & 1 & 0 & 1 \\
\hline LA & 1 & 1 & 1 & 1 & 0 & 0 & 0 & 1 & 1 & 0 & 1 \\
\hline$M D$ & 1 & 1 & $i$ & 0 & 0 & 0 & 1 & 1 & 0 & 1 & 1 \\
\hline MT & 1 & 1 & 1 & 0 & $i$ & $i$ & $i$ & $i$ & $i$ & 0 & $i$ \\
\hline$A R$ & 1 & 1 & 1 & 0 & 1 & 1 & 0 & 1 & 1 & 0 & 1 \\
\hline LA & 1 & 1 & 1 & 1 & 0 & 0 & 0 & 1 & 1 & 0 & 1 \\
\hline$A R$ & 1 & 1 & 1 & 0 & 1 & 1 & 0 & 1 & 1 & 0 & 1 \\
\hline LD & $i$ & $i$ & $i$ & 0 & $i$ & $i$ & 0 & $i$ & 0 & $i$ & $i$ \\
\hline$A R$ & 1 & 1 & 1 & 0 & 1 & 1 & 0 & 1 & 1 & 0 & 1 \\
\hline 21 & 1 & 1 & 1 & 0 & 1 & 1 & 0 & 1 & 0 & 1 & 1 \\
\hline 21 & 1 & 1 & $i$ & 0 & 0 & 0 & 1 & 1 & 0 & 1 & 1 \\
\hline $2 i$ & $i$ & $i$ & $i$ & 0 & 1 & $i$ & 0 & $i$ & 0 & $i$ & $i$ \\
\hline LA & 1 & $i$ & 1 & 0 & 1 & 1 & 0 & 1 & 0 & 1 & 1 \\
\hline 21 & 1 & 1 & $i$ & 0 & 0 & 0 & 1 & 1 & 0 & 1 & 1 \\
\hline$A R$ & 1 & 1 & 1 & 1 & 0 & 0 & 0 & 1 & 1 & 0 & 1 \\
\hline LÀ & 1 & $i$ & $i$ & i & 0 & $\overline{0}$ & 0 & $i$ & $\mathrm{i}$ & 0 & $i$ \\
\hline $\mathrm{RP}$ & 1 & 1 & $i$ & 0 & 1 & 1 & 0 & 1 & 0 & 1 & 1 \\
\hline 21 & 1 & 1 & 1 & 0 & 1 & 1 & 0 & 1 & 0 & 1 & 1 \\
\hline AM & 1 & 1 & 1 & 0 & 1 & 1 & 0 & 1 & 0 & 1 & 1 \\
\hline $2 \mathrm{i}$ & $i$ & $i$ & $i$ & 0 & $i$ & $i$ & 0 & $i$ & 0 & $i$ & $i$ \\
\hline$A M$ & $i$ & 1 & 1 & 0 & 1 & 1 & 0 & 1 & 0 & 1 & 1 \\
\hline 21 & 1 & 1 & 1 & 0 & 1 & 1 & 0 & 1 & 0 & 1 & 1 \\
\hline AR & 1 & 1 & 1 & 1 & 0 & 0 & 0 & 1 & 1 & 0 & 1 \\
\hline$A R$ & 1 & 1 & $i$ & 0 & 1 & 1 & 0 & 1 & 0 & 1 & 1 \\
\hline 21 & 1 & 1 & 1 & 0 & 1 & 1 & 0 & 1 & 0 & 1 & 1 \\
\hline 21 & 1 & 1 & 1 & 0 & 1 & 1 & 0 & 1 & 0 & 1 & 1 \\
\hline 21 & 1 & 1 & 1 & 0 & 1 & 1 & 0 & 1 & 0 & 1 & 1 \\
\hline LA & $i$ & 1 & 1 & 0 & 1 & 1 & 0 & 1 & 0 & 1 & 1 \\
\hline AR & 1 & 1 & 1 & 1 & 0 & 0 & 0 & 1 & 1 & 0 & 1 \\
\hline RP & 1 & 1 & 1 & 0 & 1 & 1 & 0 & 1 & 0 & 1 & $i$ \\
\hline 21 & 1 & 1 & 1 & 0 & 1 & 1 & 0 & 1 & 0 & 1 & 1 \\
\hline MT & 1 & 1 & 1 & 0 & 1 & $i$ & 1 & 1 & 1 & 0 & 1 \\
\hline 21 & 1 & 1 & 1 & 0 & 1 & 1 & 0 & 1 & 0 & 1 & 1 \\
\hline 21 & 1 & 1 & 1 & 0 & 1 & 1 & 0 & 1 & 0 & 1 & 1 \\
\hline 21 & 1 & 1 & 1 & 0 & 1 & $i$ & 0 & 1 & 0 & 1 & 1 \\
\hline 21 & 1 & 1 & 1 & 0 & 1 & 1 & 0 & 1 & 0 & 1 & 1 \\
\hline RP & 1 & 1 & 1 & 0 & 1 & 1 & 0 & 1 & 0 & 1 & 1 \\
\hline RP & 1 & 1 & 1 & 0 & 1 & 1 & 0 & 1 & 0 & 1 & 1 \\
\hline 21 & 1 & $i$ & 1 & 0 & 1 & 1 & 0 & 1 & 0 & 1 & 1 \\
\hline$A M$ & 1 & 1 & 1 & 0 & 1 & 1 & 0 & 1 & 0 & 1 & 1 \\
\hline AM & 1 & 1 & 1 & 0 & 1 & 1 & 0 & 1 & 0 & 1 & 1 \\
\hline 21 & 1 & 1 & 1 & 0 & 0 & 0 & 1 & 1 & 0 & 1 & 1 \\
\hline$R P$ & 1 & 1 & 1 & 0 & 1 & 1 & 0 & 1 & 0 & 1 & 1 \\
\hline$A M$ & 1 & 1 & 1 & 0 & 1 & 1 & 0 & 1 & 0 & 1 & 1 \\
\hline 21 & 1 & 1 & 1 & 0 & 0 & 0 & 1 & 1 & 0 & 1 & 1 \\
\hline$A M$ & 1 & 1 & 1 & 0 & 1 & 1 & 0 & 1 & 0 & 1 & 1 \\
\hline
\end{tabular}


Apêndice 3- Dados originais de isoenzimas da roça DFG.

\begin{tabular}{|c|c|c|c|c|c|c|c|c|c|c|c|c|c|}
\hline indiv. & $\mathrm{MDH} 1$ & $\mathrm{MDH} 2$ & $\mathrm{MDH} 3$ & $3 \mathrm{MOH} 4$ & MOH5 & $5 \mathrm{MDH} 6$ & MDH 7 & MOH 8 & SK 1 & SK 2 & SK 3 & SK 4 & SK5 \\
\hline$L P$ & 1 & 0 & 1 & 1 & 1 & 1 & 1 & 1 & 0 & 0 & 1 & 0 & 1 \\
\hline$P$ & 0 & 1 & 0 & 0 & $i$ & $i$ & 1 & 1 & 1 & 0 & 0 & 0 & 1 \\
\hline C & 0 & 1 & 0 & 0 & 1 & 1 & 1 & 1 & 0 & 0 & 1 & 0 & 1 \\
\hline$C A$ & 0 & 1 & 0 & 0 & 1 & 1 & 1 & 1 & 0 & 0 & 0 & 1 & 0 \\
\hline CA & 0 & 1 & 0 & 0 & 1 & 1 & 1 & 1 & 0 & 0 & 0 & 1 & 0 \\
\hline RO & 1 & 0 & 1 & 1 & 1 & 1 & 1 & 1 & 0 & 0 & 1 & 0 & 1 \\
\hline$C A$ & 0 & 1 & 0 & 0 & 1 & 1 & 1 & 1 & 0 & 0 & 0 & 1 & 0 \\
\hline CA & 0 & 1 & 0 & 0 & 1 & 1 & 1 & 1 & 0 & 0 & 0 & 1 & 0 \\
\hline C & 0 & 1 & 0 & 0 & 1 & 1 & 1 & 1 & 0 & 0 & 1 & 0 & 1 \\
\hline$P$ & 0 & 1 & 0 & 0 & 1 & 1 & 1 & 1 & 1 & 0 & 0 & 0 & 1 \\
\hline C & 0 & 1 & 0 & 0 & 1 & 1 & 1 & 1 & 0 & 0 & 1 & 0 & 1 \\
\hline LP & 0 & 1 & 0 & 0 & 1 & 1 & 1 & 1 & 0 & 0 & 0 & 1 & 0 \\
\hline RO & 1 & 0 & 1 & 1 & 1 & $i$ & 1 & 1 & 0 & 0 & 1 & 0 & 1 \\
\hline C & 0 & 1 & 0 & 0 & 1 & 1 & 1 & 1 & 0 & 0 & 1 & 0 & 1 \\
\hline$C A$ & 0 & 1 & 0 & 0 & 1 & $i$ & 1 & 1 & 0 & 0 & 0 & 1 & 0 \\
\hline$M$ & 0 & 1 & 0 & 0 & 1 & 1 & 1 & 1 & 0 & 0 & 0 & 1 & 0 \\
\hline MR & 0 & 1 & 0 & 0 & 1 & 1 & 1 & 1 & 0 & 0 & 1 & 0 & 1 \\
\hline$M$ & 0 & 1 & 0 & 0 & 1 & 1 & 1 & 1 & 0 & 0 & 0 & 1 & 0 \\
\hline MB & 1 & 0 & 1 & 1 & 1 & 1 & 1 & 1 & 0 & 0 & 1 & 0 & 1 \\
\hline C & 0 & 1 & 0 & 0 & 1 & 1 & 1 & 1 & 0 & 0 & 1 & 0 & 1 \\
\hline$M$ & 0 & 1 & 0 & 0 & 1 & 1 & 1 & 1 & 0 & 0 & 0 & 1 & 0 \\
\hline RO & 1 & 0 & 1 & 1 & 1 & 1 & 1 & 1 & 0 & 0 & 1 & 0 & 1 \\
\hline$M$ & 0 & 1 & 0 & 0 & 1 & 1 & 1 & 1 & 0 & 0 & 0 & 1 & 0 \\
\hline$P$ & 0 & 1 & 0 & 0 & 1 & 1 & 1 & 1 & 1 & 0 & 0 & 0 & 1 \\
\hline$M$ & 0 & 1 & 0 & 0 & 1 & 1 & 1 & 1 & 0 & 0 & 0 & 1 & 0 \\
\hline LP & 1 & 0 & 1 & 1 & 1 & 1 & 1 & 1 & 1 & 0 & 0 & 0 & 1 \\
\hline$P$ & 0 & 1 & 0 & 0 & 1 & 1 & 1 & $i$ & 1 & 0 & 0 & 0 & 1 \\
\hline LB & 1 & 0 & 1 & 1 & 1 & 1 & 1 & 1 & 0 & 0 & 1 & 0 & 1 \\
\hline$M$ & 0 & 1 & 0 & 0 & 1 & 1 & 1 & $i$ & 0 & 0 & 0 & 1 & 0 \\
\hline$L P$ & 1 & 0 & 1 & 1 & 1 & 1 & 1 & 1 & 0 & 0 & 1 & 0 & 1 \\
\hline $\mathrm{NI}$ & 0 & 1 & 0 & 0 & 1 & 1 & 1 & 1 & 0 & 0 & 0 & 1 & 0 \\
\hline $\mathbf{M}$ & 0 & 1 & 0 & 0 & 1 & 1 & 1 & 1 & 0 & 0 & 0 & 1 & 0 \\
\hline$C A$ & 0 & 1 & 0 & 0 & 1 & 1 & 1 & 1 & 0 & 0 & 0 & 1 & 0 \\
\hline$P$ & 0 & 1 & 0 & 0 & 1 & 1 & 1 & 1 & 1 & 0 & 0 & 0 & 1 \\
\hline$C A$ & 0 & 1 & 0 & 0 & 1 & 1 & 1 & 1 & 0 & 0 & 0 & 1 & 0 \\
\hline $\mathrm{P}$ & 0 & 1 & 0 & 0 & 1 & 1 & 1 & 1 & 1 & 0 & 0 & 0 & 1 \\
\hline M & 0 & 1 & 0 & 0 & 1 & 1 & 1 & 1 & 0 & 0 & 0 & 1 & 0 \\
\hline$M$ & 0 & 1 & 0 & 0 & 1 & 1 & 1 & 1 & 0 & 0 & 0 & 1 & 0 \\
\hline$M$ & 0 & 1 & 0 & 0 & 1 & 1 & 1 & 1 & 0 & 0 & 0 & 1 & 0 \\
\hline MF & 0 & 1 & 0 & 0 & 1 & 1 & 1 & 1 & 0 & 0 & 1 & 0 & 1 \\
\hline$C A$ & 0 & 1 & 0 & 0 & 1 & 1 & 1 & 1 & 0 & 0 & 0 & 1 & 0 \\
\hline$P$ & 0 & 1 & 0 & 0 & 1 & 1 & 1 & 1 & 0 & 0 & 1 & 0 & 1 \\
\hline$P$ & 0 & 1 & 0 & 0 & 1 & 1 & 1 & 1 & 1 & 0 & 0 & 0 & 1 \\
\hline C & 0 & 1 & 0 & 0 & 1 & 1 & 1 & 1 & 0 & 0 & 1 & 0 & 1 \\
\hline
\end{tabular}


Apêndice 3- Dados originais de isoenzimas da roça DFG.

\begin{tabular}{|c|c|c|c|c|c|c|c|c|c|c|c|c|c|}
\hline indiv. & MDH 1 & $\mathrm{MDH} 2$ & MDH 3 & MOH 4 & MDH 5 & MDH 6 & MDH 7 & MDH 8 & SK 1 & SK 2 & SK 3 & SK 4 & SK 5 \\
\hline$P$ & 0 & 1 & 0 & 0 & 1 & 1 & 1 & 1 & 1 & 0 & 0 & 0 & 1 \\
\hline LF & 1 & 0 & 1 & 1 & 1 & 1 & 1 & 1 & 0 & 0 & 1 & 0 & 1 \\
\hline$M$ & 0 & 1 & 0 & 0 & 1 & 1 & 1 & 1 & 0 & 0 & 0 & 1 & 0 \\
\hline$M B$ & 1 & 0 & 1 & 1 & 1 & 1 & 1 & 1 & 0 & 0 & 1 & 0 & 1 \\
\hline LB & 1 & 0 & 1 & 1 & 1 & 1 & 1 & 1 & 0 & 0 & 0 & 0 & 1 \\
\hline$P$ & 0 & 1 & 0 & 0 & 1 & 1 & 1 & 1 & 1 & 0 & 0 & 0 & 1 \\
\hline RB & 0 & 1 & 0 & 0 & 1 & 1 & 1 & 1 & 1 & 0 & 0 & 0 & 1 \\
\hline$C A$ & 0 & 1 & 0 & 0 & 1 & 1 & 1 & 1 & 0 & 0 & 0 & 1 & 0 \\
\hline$L P$ & 1 & 0 & 1 & 1 & 1 & 1 & 1 & 1 & 1 & 0 & 0 & 0 & 1 \\
\hline CA & 0 & 1 & 0 & 0 & 1 & 1 & 1 & 1 & 0 & 0 & 0 & 1 & 0 \\
\hline LP & 1 & 0 & 1 & 1 & 1 & 1 & 1 & 1 & 1 & 0 & 0 & 0 & 1 \\
\hline$C A$ & 0 & 1 & 0 & 0 & $i$ & 1 & 1 & 1 & 0 & 0 & 0 & 1 & 0 \\
\hline$P$ & 0 & 1 & 0 & 0 & 1 & 1 & 1 & 1 & 1 & 0 & 0 & 0 & 1 \\
\hline$C A$ & 0 & 1 & 0 & 0 & 1 & 1 & 1 & 1 & 0 & 0 & 0 & 1 & 0 \\
\hline NI & 1 & 0 & 1 & 1 & 1 & 1 & $i$ & 1 & 1 & 0 & 0 & 0 & 1 \\
\hline NI & 0 & 1 & 0 & 0 & 1 & 1 & 1 & 9 & 0 & 0 & 0 & 1 & 0 \\
\hline NI & 0 & 1 & 0 & 0 & 1 & 1 & 1 & 1 & 0 & 0 & 0 & 1 & 0 \\
\hline NI & 0 & 1 & 0 & 0 & 1 & 1 & 1 & 1 & 0 & 0 & 0 & 1 & 0 \\
\hline
\end{tabular}


Apêndice 3- Dados originais de isoenzimas da roça DFG.

\begin{tabular}{|c|c|c|c|c|c|c|c|c|c|c|c|}
\hline Indiv & PGI I & PGI 2 & PGI 3 & PGI 4 & PGI 5 & PGI 6 & PGI 7 & LAP 1 & LAP 2 & LAP 3 & LAP 4 \\
\hline LP & 1 & 1 & 1 & 0 & 1 & 1 & 0 & 1 & 0 & 1 & 1 \\
\hline$P$ & 1 & 1 & 1 & 0 & 0 & 0 & 1 & 1 & 0 & 1 & 1 \\
\hline C & 1 & 1 & 1 & 0 & 1 & 1 & 0 & 1 & 0 & 1 & 1 \\
\hline$C A$ & 1 & 1 & 1 & 0 & 1 & 1 & 0 & 1 & 1 & 0 & 1 \\
\hline$C A$ & 1 & 1 & 1 & 0 & 1 & 1 & 0 & 1 & 1 & 0 & 1 \\
\hline RO & 1 & 1 & 1 & 0 & 1 & 1 & 0 & 1 & 0 & 1 & 1 \\
\hline CA & 1 & 1 & 1 & 0 & 1 & 1 & 0 & 1 & 1 & 0 & 1 \\
\hline CA & 1 & 1 & 1 & 0 & 1 & 1 & 0 & 1 & 1 & 0 & 1 \\
\hline C & 1 & 1 & 1 & 0 & 1 & 1 & 0 & 1 & 0 & 1 & 1 \\
\hline P & 1 & 1 & 1 & 0 & 0 & 0 & 1 & 1 & 0 & 1 & 1 \\
\hline C & 1 & 1 & 1 & 0 & 1 & 1 & 0 & 1 & 0 & 1 & 1 \\
\hline LP & 1 & 1 & 1 & 0 & 1 & 1 & 0 & 1 & 1 & 0 & 1 \\
\hline RO & 1 & 1 & 1 & 0 & 1 & 1 & 0 & 1 & 0 & 1 & 1 \\
\hline C & 1 & 1 & 1 & 0 & 1 & 1 & 0 & 1 & 0 & 1 & 1 \\
\hline$C A$ & 1 & 1 & 1 & 0 & 1 & 1 & 0 & 1 & 1 & 0 & 1 \\
\hline$M$ & 1 & 1 & 1 & 0 & 1 & 1 & 0 & 1 & 1 & 0 & 1 \\
\hline MR & 1 & 1 & 1 & 0 & 1 & 1 & 0 & 1 & 1 & 0 & 1 \\
\hline$M$ & 1 & 1 & 1 & 0 & 1 & 1 & 0 & 1 & 1 & 0 & 1 \\
\hline$M B$ & 1 & 1 & 1 & 0 & 1 & 1 & 0 & 1 & 1 & 0 & 1 \\
\hline C & 1 & 1 & 1 & 0 & 1 & 1 & 0 & 1 & 0 & 1 & 1 \\
\hline$M$ & 1 & 1 & 1 & 0 & 1 & 1 & 0 & 1 & 1 & 0 & 1 \\
\hline RO & 1 & 1 & 1 & 0 & 1 & 1 & 0 & 1 & 0 & 1 & 1 \\
\hline$M$ & 1 & 1 & 1 & 0 & 1 & 1 & 0 & 1 & 1 & 0 & 1 \\
\hline$P$ & 1 & 1 & 1 & 0 & 0 & 0 & 1 & 1 & 0 & 1 & 1 \\
\hline$M$ & 1 & 1 & 1 & 0 & 1 & 1 & 0 & 1 & 1 & 0 & 1 \\
\hline LP & 1 & 1 & 1 & 0 & 1 & 1 & 0 & 1 & 0 & 1 & 1 \\
\hline$P$ & 1 & 1 & 1 & 0 & 0 & 0 & 1 & 1 & 0 & 1 & 1 \\
\hline$\angle 8$ & 1 & 1 & 1 & 0 & 1 & 1 & 0 & 1 & 1 & 0 & 1 \\
\hline$M$ & 1 & 1 & 1 & 0 & 1 & 1 & 0 & 1 & 1 & 0 & 1 \\
\hline LP & 1 & 1 & 1 & 0 & 1 & 1 & 0 & 1 & 1 & 0 & 1 \\
\hline NI & 1 & 1 & 1 & 0 & 1 & 1 & 0 & 1 & 1 & 0 & 1 \\
\hline$M$ & 1 & 1 & 1 & 0 & 1 & 1 & 0 & 1 & 1 & 0 & 1 \\
\hline$C A$ & 1 & 1 & 1 & 0 & 1 & 1 & 0 & 1 & 1 & 0 & 1 \\
\hline$P$ & 1 & 1 & 1 & 0 & 0 & 0 & 1 & 1 & 0 & 1 & 1 \\
\hline$C A$ & 1 & 1 & 1 & 0 & 1 & 1 & 0 & 1 & 1 & 0 & 1 \\
\hline$P$ & 1 & 1 & 1 & 0 & 0 & 0 & 1 & 1 & 0 & 1 & 1 \\
\hline$M$ & 1 & 1 & 1 & 0 & 1 & 1 & 0 & 1 & 1 & 0 & 1 \\
\hline$M$ & 1 & 1 & 1 & 0 & 1 & 1 & 0 & 1 & 1 & 0 & 1 \\
\hline$M$ & 1 & 1 & 1 & 0 & 1 & 1 & 0 & 1 & 1 & 0 & 1 \\
\hline MF & 1 & 1 & 1 & 0 & 1 & 1 & 0 & 1 & 0 & 1 & 1 \\
\hline$C A$ & 1 & 1 & 1 & 0 & 1 & 1 & 0 & 1 & 1 & 0 & 1 \\
\hline$P$ & 1 & 1 & 1 & 0 & 1 & 1 & 0 & 1 & 1 & 0 & 1 \\
\hline$P$ & 1 & 1 & 1 & 0 & 0 & 0 & 1 & 1 & 0 & 1 & 1 \\
\hline C & 1 & 1 & 1 & 0 & 1 & 1 & 0 & 1 & 0 & 1 & 1 \\
\hline
\end{tabular}


Apêndice 3- Dados originais de isoenzimas da roça DFG.

$\begin{array}{cccccccccccc}\text { indN } & P G 11 & P G 12 & P G 13 & P G 14 & P G 15 & P G I 6 & P G I 7 & \text { LAP } 1 & \text { LAP } 2 & \text { LAP 3 } & \text { LAP } 4 \\ \text { P } & 1 & 1 & 1 & 0 & 0 & 0 & 1 & 1 & 0 & 1 & 1 \\ \text { LF } & 1 & 1 & 1 & 0 & 1 & 1 & 0 & 1 & 0 & 1 & 1 \\ M & 1 & 1 & 1 & 0 & 1 & 1 & 0 & 1 & 1 & 0 & 1 \\ \text { MB } & 1 & 1 & 1 & 0 & 1 & 1 & 1 & 1 & 1 & 0 & 1 \\ \text { LB } & 1 & 1 & 1 & 0 & 1 & 1 & 0 & 1 & 1 & 0 & 1 \\ P & 1 & 1 & 1 & 0 & 0 & 0 & 1 & 1 & 0 & 1 & 1 \\ \text { RB } & 1 & 1 & 1 & 0 & 0 & 0 & 1 & 1 & 0 & 1 & 1 \\ \text { CA } & 1 & 1 & 1 & 0 & 1 & 1 & 0 & 1 & 1 & 0 & 1 \\ \text { LP } & 1 & 1 & 1 & 0 & 1 & 1 & 0 & 1 & 0 & 1 & 1 \\ \text { CA } & 1 & 1 & 1 & 0 & 1 & 1 & 0 & 1 & 1 & 0 & 1 \\ \text { LP } & 1 & 1 & 1 & 0 & 1 & 1 & 0 & 1 & 0 & 1 & 1 \\ \text { CA } & 1 & 1 & 1 & 0 & 1 & 1 & 0 & 1 & 1 & 0 & 1 \\ P & 1 & 1 & 1 & 0 & 0 & 0 & 1 & 1 & 0 & 1 & 1 \\ \text { CA } & 1 & 1 & 1 & 0 & 1 & 1 & 0 & 1 & 1 & 0 & 1 \\ \text { NI } & 1 & 1 & 1 & 0 & 1 & 1 & 0 & 1 & 0 & 1 & 1 \\ \text { NI } & 1 & 1 & 1 & 0 & 1 & 1 & 0 & 1 & 1 & 0 & 1 \\ \text { NI } & 1 & 1 & 1 & 0 & 1 & 1 & 0 & 1 & 1 & 0 & 1 \\ \text { NI } & 1 & 1 & 1 & 0 & 1 & 1 & 0 & 1 & 1 & 0 & 1\end{array}$


Apêndice 4- Dados originais de isoenzimas da roça FA

\begin{tabular}{|c|c|c|c|c|c|c|c|c|c|c|c|c|c|}
\hline Indiv. & MOH 1 & MOH 2 & $\mathrm{MDH} 3$ & $3 \mathrm{MDH} 4$ & $4 \mathrm{MDH} 5$ & MDH 6 & $6 \mathrm{MDH} 7$ & MDH 8 & SK 1 & SK 2 & SK 3 & SK 4 & SK 5 \\
\hline AP & 1 & 0 & 1 & 1 & 1 & 1 & 1 & 1 & 1 & 0 & 0 & 0 & 1 \\
\hline$M$ & 0 & 1 & 0 & 0 & 1 & 1 & 4 & 1 & 0 & 0 & 1 & 0 & 1 \\
\hline$R$ & 1 & 0 & 1 & 1 & 1 & 1 & 1 & 1 & 0 & 0 & 0 & 1 & 0 \\
\hline M & 0 & 1 & 0 & 0 & 1 & 1 & 1 & 1 & 0 & 0 & 0 & 1 & 0 \\
\hline M & 0 & 1 & 0 & 0 & 1 & 1 & 1 & 1 & 0 & 0 & 0 & 1 & 0 \\
\hline$M$ & 0 & 1 & 0 & 0 & 1 & 1 & 1 & 1 & 0 & 0 & 0 & 1 & 0 \\
\hline M & 0 & 1 & 0 & 0 & 1 & 1 & 1 & 1 & 0 & 0 & 0 & 1 & 0 \\
\hline$z$ & 0 & 1 & 0 & 0 & 1 & 1 & 1 & 1 & 0 & 0 & 1 & 0 & 1 \\
\hline$M$ & 0 & 1 & 0 & 0 & 1 & 1 & 1 & 1 & 0 & 0 & 0 & 1 & 0 \\
\hline M & 0 & 1 & 0 & 0 & 1 & 1 & 1 & 1 & 0 & 0 & 0 & 1 & 0 \\
\hline M & 0 & 1 & 0 & 0 & 1 & 1 & 1 & 1 & 0 & 0 & 0 & 1 & 0 \\
\hline M & 0 & 1 & 0 & 0 & 1 & 1 & 1 & 1 & 0 & 0 & 0 & 1 & 0 \\
\hline M & 0 & 1 & 0 & 0 & 1 & 1 & 1 & 1 & 0 & 0 & 0 & 1 & 0 \\
\hline M & 0 & 1 & 0 & 0 & 1 & 1 & 1 & 1 & 0 & 0 & 0 & 1 & 0 \\
\hline M & 0 & 1 & 0 & 0 & 1 & 1 & 1 & 1 & 0 & 0 & 0 & 1 & 0 \\
\hline M & 0 & 1 & 0 & 0 & 1 & 1 & 1 & 1 & 0 & 0 & 0 & 1 & 0 \\
\hline M & 0 & 1 & 0 & 0 & 1 & 1 & 1 & 1 & 0 & 0 & 0 & 1 & 0 \\
\hline M & 0 & 1 & 0 & 0 & 1 & 1 & 1 & 1 & 0 & 0 & 0 & 1 & 0 \\
\hline M & 0 & 1 & 0 & 0 & 1 & 1 & 1 & 1 & 0 & 0 & 0 & 1 & 0 \\
\hline M & 0 & 1 & 0 & 0 & 1 & 1 & 1 & 1 & 0 & 0 & 0 & 1 & 0 \\
\hline$R$ & 1 & 0 & 1 & 1 & 1 & 1 & 1 & 1 & 0 & 0 & 0 & 1 & 0 \\
\hline M & 0 & 1 & 0 & 0 & 1 & 1 & 1 & 1 & 0 & 0 & 0 & 1 & 0 \\
\hline M & 0 & 1 & 0 & 0 & 1 & 1 & 1 & 1 & 0 & 0 & 0 & 1 & 0 \\
\hline$M$ & 0 & 1 & 0 & 0 & 1 & 1 & 1 & 1 & 0 & 0 & 0 & 1 & 0 \\
\hline$z$ & 0 & 1 & 0 & 0 & 1 & 1 & $i$ & 1 & 0 & 0 & 1 & 0 & 1 \\
\hline M & 0 & 1 & 0 & 0 & 1 & 1 & 1 & 1 & 0 & 0 & 0 & 1 & 0 \\
\hline$R$ & 0 & 1 & 0 & 0 & 1 & 1 & 1 & 1 & 0 & 0 & 0 & 1 & 0 \\
\hline M & 0 & 1 & 0 & 0 & 1 & 1 & 1 & 1 & 0 & 0 & 0 & 1 & 0 \\
\hline M & 0 & 1 & 0 & 0 & 1 & 1 & $i$ & 1 & 0 & 0 & 0 & 1 & 0 \\
\hline$M$ & 0 & 1 & 0 & 0 & 1 & 1 & 1 & 1 & 0 & 0 & 0 & 1 & 0 \\
\hline $\mathbf{R}$ & 0 & 1 & 0 & 0 & 1 & 1 & 1 & 1 & 0 & 0 & 1 & 0 & 1 \\
\hline$M$ & 0 & 1 & 0 & 0 & 1 & 1 & 1 & 1 & 0 & 0 & 0 & 1 & 0 \\
\hline$R$ & 0 & 1 & 0 & 0 & 1 & 1 & 1 & 1 & 0 & 0 & 0 & 1 & 0 \\
\hline M & 0 & 1 & 0 & 0 & 1 & 1 & 1 & 1 & 0 & 0 & 0 & 1 & 0 \\
\hline M & 0 & 1 & 0 & 0 & 1 & 1 & 1 & 1 & 0 & 0 & 0 & 1 & 0 \\
\hline$M$ & 0 & 1 & 0 & 0 & 1 & 1 & 1 & 1 & 0 & 0 & 0 & 1 & 0 \\
\hline $\mathbf{R}$ & 0 & 1 & 0 & 0 & 1 & 1 & 1 & 1 & 0 & 0 & 1 & 0 & 1 \\
\hline$M$ & 0 & 1 & 0 & 0 & 1 & 1 & 1 & 1 & 0 & 0 & 0 & 1 & 0 \\
\hline M & 0 & 1 & 0 & 0 & 1 & 1 & 1 & 1 & 0 & 0 & 0 & 1 & 0 \\
\hline
\end{tabular}


Apêndice 4- Dados originais de isoenzimas da roça FA

\begin{tabular}{|c|c|c|c|c|c|c|c|c|c|c|c|}
\hline Indiv. & PGI 1 & $P G \mid 2$ & $P G \mid 3$ & $P G \mid 4$ & PGI 5 & PGI 6 & PGI 7 & LAP 1 & LAP 2 & LAP 3 & LAP 4 \\
\hline$A P$ & 1 & 1 & 1 & 0 & 1 & 1 & 0 & 1 & 0 & 1 & 1 \\
\hline$M$ & 1 & 1 & 1 & 0 & 1 & 1 & 0 & 1 & 0 & 1 & 1 \\
\hline$R$ & 1 & 1 & 1 & 0 & 1 & 1 & 0 & 1 & 1 & 0 & 1 \\
\hline M & 1 & 1 & 1 & 0 & 1 & 1 & 0 & 1 & 1 & 0 & 1 \\
\hline$M$ & 1 & 1 & 1 & 0 & 1 & 1 & 0 & 1 & 1 & 0 & 1 \\
\hline M & 1 & 1 & 1 & 0 & 1 & 1 & 0 & 1 & 1 & 0 & 1 \\
\hline$M$ & 1 & 1 & 1 & 0 & 1 & 1 & 0 & 1 & 1 & 0 & 1 \\
\hline$z$ & 1 & 1 & 1 & 0 & 1 & 1 & 0 & 1 & 0 & 1 & 1 \\
\hline M & 1 & 1 & 1 & 0 & 1 & 1 & 0 & 1 & 1 & 0 & 1 \\
\hline$M$ & 1 & 1 & 1 & 0 & 1 & 1 & 0 & 1 & 1 & 0 & 1 \\
\hline$M$ & 1 & 1 & 1 & 0 & 1 & 1 & 0 & 1 & 1 & 0 & 1 \\
\hline M & 1 & 1 & 1 & 0 & 1 & 1 & 0 & 1 & 1 & 0 & 1 \\
\hline M & 1 & 1 & 1 & 0 & 1 & 1 & 0 & 1 & 1 & 0 & 1 \\
\hline M & 1 & 1 & 1 & 0 & 1 & 1 & 0 & 1 & 1 & 0 & 1 \\
\hline M & 1 & 1 & 1 & 0 & 1 & 1 & 0 & 1 & 1 & 0 & 1 \\
\hline M & 1 & 1 & 1 & 0 & 1 & 1 & 0 & 1 & 1 & 0 & 1 \\
\hline M & 1 & 1 & 1 & 0 & 1 & 1 & 0 & 1 & 1 & 0 & 1 \\
\hline M & 1 & 1 & 1 & 0 & 1 & 1 & 0 & 1 & 1 & 0 & 1 \\
\hline M & 1 & 1 & 1 & 0 & 1 & 1 & 0 & 1 & 1 & 0 & 1 \\
\hline M & 1 & 1 & 1 & 0 & 1 & 1 & 0 & 1 & 1 & 0 & 1 \\
\hline$R$ & 1 & 1 & 1 & 0 & 1 & 1 & 0 & $i$ & 1 & 0 & 1 \\
\hline M & 1 & 1 & 1 & 0 & 1 & 1 & 0 & $i$ & 1 & 0 & 1 \\
\hline M & 1 & 1 & 1 & 0 & 1 & 1 & 0 & 1 & 1 & 0 & 1 \\
\hline M & 1 & 1 & 1 & 0 & 1 & 1 & 0 & 1 & 1 & 0 & 1 \\
\hline$z$ & 1 & 1 & 1 & 0 & 1 & 1 & 0 & 1 & 0 & 1 & 1 \\
\hline M & 1 & 1 & 1 & 0 & 1 & 1 & 0 & 1 & 1 & 0 & 1 \\
\hline$R$ & 1 & 1 & 1 & 0 & 1 & 1 & 0 & 1 & 0 & 1 & 1 \\
\hline$M$ & 1 & 1 & 1 & 0 & 1 & 1 & 0 & 1 & 1 & 0 & 1 \\
\hline M & 1 & 1 & 1 & 0 & 1 & 1 & 0 & 1 & 1 & 0 & 1 \\
\hline$M$ & 1 & 1 & 1 & 0 & 1 & 1 & 0 & 1 & 1 & 0 & 1 \\
\hline$R$ & 1 & 1 & 1 & 0 & 1 & 1 & 0 & 1 & 0 & 1 & 1 \\
\hline M & 1 & 1 & 1 & 0 & 1 & 1 & 0 & 1 & 1 & 0 & 1 \\
\hline $\mathbf{R}$ & 1 & 1 & 1 & 0 & 1 & 1 & 0 & 1 & 0 & 1 & 1 \\
\hline$M$ & 1 & 1 & 1 & 0 & 1 & 1 & 0 & 1 & 1 & 0 & 1 \\
\hline M & 1 & 1 & 1 & 0 & 1 & 1 & 0 & 1 & 1 & 0 & 1 \\
\hline M & 1 & 1 & 1 & 0 & 1 & 1 & 0 & 1 & 1 & 0 & 1 \\
\hline$R$ & 1 & 1 & 1 & 0 & 1 & 1 & 0 & 1 & 0 & 1 & 1 \\
\hline$M$ & 1 & 1 & 1 & 0 & 1 & 1 & 0 & 1 & 1 & 0 & 1 \\
\hline $\mathbf{M}$ & 1 & 1 & 1 & 0 & 1 & 1 & 0 & 1 & 1 & 0 & 1 \\
\hline
\end{tabular}


Apêndice 5- Dados originais de isoenzimas da roça FO.

\begin{tabular}{|c|c|c|c|c|c|c|c|c|c|c|c|c|c|}
\hline Indiv. & $\mathrm{MDH} 9$ & $\mathrm{MOH} 2$ & $\mathrm{MDH} 3$ & MDH 4 & MDH 5 & MDH 6 & MDH 7 & MDH 8 & SK 1 & SK 2 & SK 3 & SK 4 & SK 5 \\
\hline$M$ & 0 & 1 & 0 & 0 & 1 & 1 & 1 & 1 & 0 & 0 & 0 & 1 & 0 \\
\hline RO & 1 & 0 & 1 & 1 & 1 & 1 & 1 & 1 & 0 & 0 & 0 & 0 & 1 \\
\hline M & 0 & 1 & 0 & 0 & 1 & 1 & 1 & 1 & 0 & 0 & 0 & 1 & 0 \\
\hline M & 0 & 1 & 0 & 0 & 1 & 1 & 1 & 1 & 0 & 0 & 0 & 1 & 0 \\
\hline$M$ & 0 & 1 & 0 & 0 & 1 & 1 & 1 & 1 & 0 & 0 & 0 & 1 & 0 \\
\hline $\mathrm{SH}$ & 0 & 1 & 0 & 0 & 1 & 1 & 1 & 1 & 1 & 0 & 0 & 0 & 1 \\
\hline$M$ & 0 & 1 & 0 & 0 & 1 & 1 & 1 & 1 & 0 & 0 & 0 & 1 & 0 \\
\hline M & 0 & 1 & 0 & 0 & 1 & 1 & 1 & 1 & 0 & 0 & 0 & 1 & 0 \\
\hline M & 0 & 1 & 0 & 0 & 1 & 1 & 1 & 1 & 0 & 0 & 0 & 1 & 0 \\
\hline$M$ & 1 & 0 & 1 & 1 & 1 & 1 & 1 & 1 & 0 & 0 & 1 & 0 & 1 \\
\hline RO & 1 & 0 & 1 & 1 & 1 & 1 & 1 & 1 & 0 & 0 & 0 & 0 & 1 \\
\hline$M$ & 0 & 1 & 0 & 0 & 1 & 1 & 1 & 1 & 0 & 0 & 0 & 1 & 0 \\
\hline M & 0 & 1 & 0 & 0 & 1 & 1 & 1 & 1 & 0 & 0 & 0 & 1 & 0 \\
\hline M & 0 & 1 & 0 & 0 & 1 & 1 & 1 & 1 & 0 & 0 & 0 & 1 & 0 \\
\hline M & 0 & 1 & 0 & 0 & 1 & 1 & 1 & 1 & 0 & 0 & 0 & 1 & 0 \\
\hline M & 0 & 1 & 0 & 0 & 1 & 1 & 1 & $f$ & 0 & 0 & 0 & 1 & 0 \\
\hline M & 0 & 1 & 0 & 0 & 1 & 1 & 1 & $i$ & 0 & 0 & 0 & 1 & 0 \\
\hline M & 0 & 1 & 0 & 0 & 1 & 1 & 1 & 1 & 0 & 0 & 0 & 1 & 0 \\
\hline$z$ & 0 & 1 & 0 & 0 & 1 & $i$ & 1 & $i$ & 0 & 0 & 0 & 1 & 0 \\
\hline $\bar{M}$ & 1 & 0 & 1 & 1 & 1 & 1 & 1 & 1 & 0 & 0 & 0 & 1 & 0 \\
\hline M & 0 & 1 & 0 & 0 & 1 & 1 & 1 & 1 & 0 & 0 & 0 & 1 & 0 \\
\hline M & 0 & 1 & 0 & 0 & 1 & 1 & 1 & 1 & 0 & 0 & 0 & 1 & 0 \\
\hline$M$ & 0 & 1 & 0 & 0 & 1 & $i$ & 1 & 1 & 0 & 0 & 0 & 1 & 0 \\
\hline M & 0 & 1 & 0 & 0 & 1 & 1 & 1 & 1 & 0 & 0 & 0 & 1 & 0 \\
\hline$z$ & 0 & 1 & 0 & 0 & 1 & 1 & 1 & 1 & 0 & 0 & 0 & 1 & 0 \\
\hline M & 0 & 1 & 0 & 0 & 1 & 1 & 1 & 1 & 0 & 0 & 0 & 1 & 0 \\
\hline M & 0 & 1 & 0 & 0 & 1 & 1 & 1 & 1 & 0 & 0 & 0 & 1 & 0 \\
\hline 21 & 0 & 1 & 0 & 0 & 1 & 1 & 1 & 1 & 0 & 0 & 0 & 1 & 0 \\
\hline$M$ & 0 & 1 & 0 & 0 & 1 & 1 & 1 & 1 & 0 & 0 & 0 & 1 & 0 \\
\hline$M$ & 0 & 1 & 0 & 0 & 1 & 1 & 1 & 1 & 0 & 0 & 0 & 1 & 0 \\
\hline$M$ & 0 & 1 & 0 & 0 & 1 & 1 & $i$ & $i$ & 0 & 0 & 0 & 1 & 0 \\
\hline$z$ & 0 & 1 & 0 & 0 & 1 & 1 & 1 & 1 & 0 & 0 & 1 & 0 & 1 \\
\hline M & 0 & 1 & 0 & 0 & 1 & 1 & 1 & 1 & 0 & 0 & 0 & 1 & 0 \\
\hline M & 0 & 1 & 0 & 0 & 1 & 1 & 1 & 1 & 0 & 0 & 0 & 1 & 0 \\
\hline
\end{tabular}


Apêndice 5- Dados originais de isoenzimas da roça FO.

\begin{tabular}{|c|c|c|c|c|c|c|c|c|c|c|c|}
\hline Indiv. & PGI 1 & $P G \mid 2$ & $P G \mid 3$ & PGI 4 & PGI 5 & PGI 6 & PGI 7 & LAP 1 & LAP 2 & LAP 3 & LAP 4 \\
\hline$M$ & 1 & 1 & 1 & 0 & 1 & 1 & 0 & 1 & 1 & 0 & \\
\hline RO & 1 & 1 & 1 & 1 & 0 & 0 & 0 & 1 & 0 & 1 & \\
\hline$M$ & 1 & 1 & 1 & 0 & 1 & 1 & 0 & 1 & 1 & 0 & 1 \\
\hline M & 1 & 1 & 1 & 0 & 1 & 1 & 0 & 1 & 1 & 0 & 1 \\
\hline$M$ & 1 & 1 & 1 & 0 & 1 & 1 & 0 & 1 & 1 & 0 & 1 \\
\hline $\mathrm{SH}$ & 1 & 1 & 1 & 0 & 1 & 1 & 0 & 1 & 1 & 0 & 1 \\
\hline$M$ & 1 & 1 & 1 & 0 & 1 & 1 & 0 & 1 & 1 & 0 & 1 \\
\hline$M$ & 1 & 1 & 1 & 0 & 1 & 1 & 0 & 1 & 1 & 0 & 1 \\
\hline M & 1 & 1 & 1 & 0 & 1 & 1 & 0 & 1 & 1 & 0 & 1 \\
\hline$M$ & $i$ & 1 & $i$ & 0 & 1 & 1 & 0 & 1 & 0 & 1 & 1 \\
\hline RO & 1 & $i$ & 1 & 1 & 0 & 0 & 0 & 1 & 0 & 1 & 1 \\
\hline$M$ & 1 & 1 & 1 & 0 & 1 & 1 & 0 & 1 & 1 & 0 & 1 \\
\hline M & $i$ & 1 & 1 & 0 & 1 & 1 & 0 & 1 & 1 & 0 & 1 \\
\hline M & $i$ & $i$ & $i$ & 0 & 1 & $i$ & 0 & 1 & 1 & 0 & 1 \\
\hline M & 1 & 1 & 1 & 0 & 1 & 1 & 0 & 1 & 1 & 0 & 1 \\
\hline$M$ & $i$ & 1 & 1 & 0 & 1 & 1 & 0 & 1 & 1 & 0 & 1 \\
\hline$M$ & $i$ & 1 & 1 & 0 & 1 & 1 & 0 & $i$ & 1 & 0 & 1 \\
\hline M & 1 & 1 & 1 & 0 & $i$ & 1 & 0 & 1 & 1 & 0 & 1 \\
\hline z & 1 & $i$ & 1 & 0 & 1 & $i$ & 0 & 1 & 0 & 1 & 1 \\
\hline $\bar{M}$ & 1 & 1 & $i$ & 0 & 1 & 1 & 0 & 1 & 1 & 0 & 1 \\
\hline M & 1 & 1 & 1 & 0 & 1 & 1 & 0 & 1 & 1 & 0 & 1 \\
\hline$M$ & $i$ & $i$ & $i$ & 0 & 1 & 1 & 0 & 1 & 1 & 0 & 1 \\
\hline M & 1 & 1 & 1 & 0 & 1 & 1 & 0 & 1 & 1 & 0 & 1 \\
\hline M & 1 & 1 & 1 & 0 & 1 & 1 & 0 & 1 & 1 & 0 & 1 \\
\hline$z$ & 1 & 1 & 1 & 0 & 1 & 1 & 0 & 1 & 0 & 0 & 1 \\
\hline $\bar{M}$ & $i$ & i & 1 & 0 & 1 & 1 & 0 & 1 & 1 & 0 & 1 \\
\hline M & 1 & 1 & 1 & 0 & 1 & 1 & 0 & 1 & 1 & 0 & 1 \\
\hline 21 & 1 & 1 & 1 & 0 & 1 & 1 & 0 & 1 & 1 & 0 & 1 \\
\hline $\bar{M}$ & 1 & 1 & 1 & 0 & 1 & 1 & 0 & 1 & 1 & 0 & 1 \\
\hline$M$ & 1 & $i$ & 1 & 0 & 1 & 1 & 0 & 1 & 1 & 0 & 1 \\
\hline$M$ & 1 & 1 & 1 & 0 & 1 & 1 & 0 & 1 & 1 & 0 & 1 \\
\hline$z$ & 1 & 1 & $i$ & 0 & 1 & 1 & 0 & 1 & 0 & 0 & 1 \\
\hline $\bar{M}$ & 1 & 1 & 1 & 0 & 1 & 1 & 0 & 1 & 1 & 0 & 1 \\
\hline$M$ & 1 & 1 & 1 & 0 & 1 & 1 & 0 & 1 & 1 & 0 & \\
\hline
\end{tabular}


Apêndice 6- Dados originais de isoenzimas da roça DFP.

\begin{tabular}{|c|c|c|c|c|c|c|c|c|c|c|c|c|c|}
\hline Indiv. & MDH 1 & MDH 2 & $\mathrm{MDH} 3$ & MDH 4 & MOH 5 & MDH 6 & MDH 7 & MDH 8 & SK 1 & SK 2 & SK 3 & SK 4 & SK 5 \\
\hline 1 & 0 & 1 & 0 & 0 & 1 & 1 & 1 & 1 & 0 & 0 & 0 & 1 & 0 \\
\hline 2 & 1 & 0 & 1 & 1 & 1 & 1 & 1 & 1 & 1 & 0 & 0 & 0 & 1 \\
\hline 3 & 0 & 1 & 0 & 0 & 1 & 1 & 1 & 1 & 0 & 0 & & 0 & 1 \\
\hline 4 & 0 & 1 & 0 & 0 & 1 & 1 & 1 & 1 & 0 & 0 & 0 & 1 & 0 \\
\hline 5 & 0 & 1 & 0 & 0 & 1 & 1 & 1 & 1 & 0 & 0 & 0 & 1 & 0 \\
\hline 6 & 0 & 1 & 0 & 0 & 1 & 1 & 1 & 1 & 1 & 0 & 0 & 0 & 1 \\
\hline 7 & 0 & 1 & 0 & 0 & 1 & 1 & 1 & 1 & 1 & 0 & 0 & 0 & 1 \\
\hline 8 & 0 & 1 & 0 & 0 & 1 & 1 & 1 & 1 & 0 & 0 & 0 & 0 & 1 \\
\hline 9 & 0 & $i$ & 0 & 0 & 1 & 1 & 1 & 1 & 1 & 0 & 0 & 0 & 1 \\
\hline 10 & 0 & 1 & 0 & 0 & 1 & 1 & 1 & 1 & 1 & 0 & 0 & 0 & 1 \\
\hline 11 & 0 & 1 & 0 & 0 & 1 & 1 & 1 & 1 & 0 & 0 & 1 & 0 & 1 \\
\hline 12 & 1 & 0 & 1 & 1 & 1 & 1 & 1 & 1 & 1 & 0 & 0 & 0 & 1 \\
\hline 13 & 0 & 1 & 0 & 0 & 1 & 1 & 1 & 1 & 0 & 0 & 0 & 1 & 0 \\
\hline 14 & 0 & 1 & 0 & 0 & 1 & 1 & 1 & 1 & 0 & 0 & 0 & 1 & 0 \\
\hline 15 & 0 & 1 & 0 & 0 & 1 & 1 & 1 & 1 & 0 & 0 & 1 & 0 & 1 \\
\hline 16 & 0 & 1 & 0 & 0 & 1 & 1 & 1 & 1 & 1 & 0 & 0 & 0 & 1 \\
\hline 17 & 0 & 1 & 0 & 0 & 1 & 1 & 1 & 1 & 1 & 0 & 0 & 0 & 1 \\
\hline 18 & 0 & 1 & 0 & 0 & 1 & 1 & 1 & 1 & 1 & 0 & 0 & 0 & 1 \\
\hline 19 & 0 & 1 & 0 & 0 & 1 & 1 & $i$ & 1 & 0 & 0 & 1 & 0 & 1 \\
\hline 20 & 0 & 1 & 0 & 0 & 1 & 1 & 1 & 1 & 0 & 0 & 1 & 0 & 1 \\
\hline 21 & 0 & 1 & 0 & 0 & 1 & 1 & 1 & 1 & 0 & 0 & 1 & 0 & 1 \\
\hline 22 & 0 & 1 & 0 & 0 & 1 & 1 & 1 & 1 & 1 & 0 & 0 & 0 & 1 \\
\hline 23 & 0 & 1 & 0 & 0 & 1 & 1 & 1 & 1 & 0 & 0 & 1 & 0 & 1 \\
\hline 24 & 0 & 1 & 0 & 0 & 1 & 1 & 1 & 1 & 0 & 0 & 0 & 1 & 0 \\
\hline 25 & 0 & 1 & 0 & 0 & 1 & 1 & 1 & 1 & 0 & 0 & 1 & 0 & 1 \\
\hline 26 & 0 & 1 & 0 & 0 & 1 & 1 & 1 & 1 & 1 & 0 & 0 & 0 & 1 \\
\hline 27 & 0 & 1 & 0 & 0 & 1 & 1 & 1 & 1 & 1 & 0 & 0 & 0 & 1 \\
\hline 28 & 0 & 1 & 0 & 0 & 1 & 1 & 1 & 1 & 0 & 0 & 0 & 1 & 0 \\
\hline 20 & 0 & $i$ & 0 & 0 & 1 & 1 & 1 & 1 & 0 & 0 & 1 & 0 & 1 \\
\hline 30 & 0 & 1 & 0 & 0 & $i$ & 1 & 1 & 1 & 0 & 0 & 1 & 0 & 1 \\
\hline 31 & 0 & 1 & 0 & 0 & $i$ & 1 & 1 & 1 & 0 & 0 & 0 & 1 & 0 \\
\hline 32 & 0 & 1 & 0 & 0 & 1 & 1 & 1 & 1 & 1 & 0 & 0 & 0 & 1 \\
\hline 33 & 0 & 1 & 0 & 0 & 1 & 1 & 1 & 1 & 0 & 0 & 1 & 0 & 1 \\
\hline 34 & 0 & 1 & 0 & 0 & 1 & 1 & 1 & 1 & 0 & 1 & 0 & 1 & 0 \\
\hline 35 & 0 & 1 & 0 & 0 & 1 & 1 & 1 & 1 & 1 & 0 & 0 & 0 & 1 \\
\hline 36 & 0 & 1 & 0 & 0 & 1 & 1 & 1 & 1 & 0 & 0 & 0 & 1 & 0 \\
\hline
\end{tabular}


Apêndice 6 - Dados originais de isoenzimas da roça DFP.

\begin{tabular}{|c|c|c|c|c|c|c|c|c|c|c|c|}
\hline indir. & PGI 1 & $P G \mid 2$ & PGI3 & PGI 4 & PGI 5 & PGI 6 & PGI 7 & LAP 1 & LAP 2 & LAP 3 & LAP 4 \\
\hline 1 & 1 & 1 & 1 & 0 & 1 & 1 & 0 & 1 & 1 & 0 & \\
\hline 2 & 1 & 1 & 1 & 0 & 1 & 1 & 0 & 1 & 0 & 1 & 1 \\
\hline 3 & 1 & 1 & 1 & 0 & 1 & 1 & 0 & 1 & 0 & 1 & 1 \\
\hline 4 & 1 & 1 & 1 & 0 & 1 & 1 & 0 & 1 & 1 & 0 & 1 \\
\hline 5 & 1 & 1 & 1 & 0 & 1 & 1 & 0 & 1 & 1 & 0 & 1 \\
\hline 6 & 1 & 1 & 1 & 0 & 0 & 0 & 1 & 1 & 0 & 1 & 1 \\
\hline 7 & 1 & 1 & 1 & 0 & 0 & 0 & 1 & 1 & 0 & 1 & 1 \\
\hline 8 & 1 & 1 & 1 & 0 & 0 & 0 & 1 & 1 & 0 & 1 & 1 \\
\hline 9 & 1 & 1 & 1 & 0 & 0 & 0 & 1 & 1 & 0 & 1 & 1 \\
\hline 10 & $i$ & $i$ & 1 & 0 & 0 & 0 & 1 & 1 & 0 & 1 & 1 \\
\hline 11 & 1 & 1 & 1 & 0 & 1 & 1 & 0 & 1 & 0 & 1 & 1 \\
\hline 12 & 1 & 1 & 1 & 0 & 1 & 1 & 0 & 1 & 0 & 1 & 1 \\
\hline 13 & 1 & 1 & 1 & 0 & 0 & 0 & 1 & 1 & 0 & 1 & 1 \\
\hline 14 & 1 & 1 & 1 & 0 & 1 & 1 & 0 & 1 & 1 & 0 & 1 \\
\hline 15 & 1 & 1 & 1 & 0 & 1 & 1 & 0 & 1 & 0 & 1 & 1 \\
\hline 16 & 1 & 1 & 1 & 0 & 0 & 0 & 1 & 1 & 0 & 1 & 1 \\
\hline 17 & 1 & 1 & 1 & 0 & 0 & 0 & 1 & 1 & 0 & 1 & 1 \\
\hline 18 & 1 & $i$ & $i$ & 0 & 0 & 0 & 1 & 1 & 0 & 1 & 1 \\
\hline 19 & 1 & 1 & 1 & 0 & 1 & 1 & 0 & 1 & 1 & 0 & 1 \\
\hline 20 & 1 & 1 & 1 & 0 & 1 & 1 & 0 & 1 & 0 & 1 & 1 \\
\hline 21 & 1 & 1 & 1 & 0 & 1 & 1 & 0 & 1 & 0 & 1 & 1 \\
\hline 22 & 1 & 1 & 1 & 0 & 0 & 0 & 1 & 1 & 0 & 1 & 1 \\
\hline 23 & 1 & 1 & 1 & 0 & 1 & 1 & 0 & 1 & 0 & 1 & 1 \\
\hline 24 & 1 & 1 & 1 & 0 & 1 & 1 & 0 & 1 & 1 & 0 & 1 \\
\hline 25 & 1 & 1 & 1 & 0 & 1 & 1 & 0 & 1 & 0 & 1 & 1 \\
\hline 26 & 1 & 1 & $i$ & 0 & 0 & 0 & 1 & 1 & 0 & 1 & 1 \\
\hline 27 & 1 & 1 & 1 & 0 & 0 & 0 & 1 & 1 & 0 & 1 & 1 \\
\hline 28 & $i$ & $i$ & 1 & 0 & 1 & 1 & 0 & 1 & 1 & 0 & 1 \\
\hline 29 & 1 & 1 & 1 & 0 & 1 & 1 & 0 & 1 & 0 & 1 & 1 \\
\hline 30 & 1 & 1 & 1 & 0 & 1 & 1 & 0 & 1 & 0 & 1 & 1 \\
\hline 31 & 1 & 1 & 1 & 0 & 1 & 1 & 0 & 1 & 1 & 0 & \\
\hline 32 & 1 & 1 & 1 & 0 & 0 & 0 & 1 & 1 & 0 & 1 & 1 \\
\hline 33 & 1 & 1 & 1 & 0 & 1 & 1 & 0 & 1 & 0 & 1 & 1 \\
\hline 34 & i & 1 & 1 & 0 & 0 & 0 & 1 & 1 & 0 & 1 & \\
\hline 35 & 1 & 1 & 1 & 0 & 1 & 1 & 0 & 1 & 0 & 1 & \\
\hline 36 & $?$ & ? & $?$ & $?$ & $?$ & $?$ & $?$ & & 1 & 0 & \\
\hline
\end{tabular}


Apêndice 7- Dados de morfologia originais da roça DFG. M9 a M14 em cm.

\begin{tabular}{|c|c|c|c|c|c|c|c|c|c|c|c|c|c|c|c|}
\hline most & $\begin{array}{c}M \\
1\end{array}$ & N2 & MB & MA & M6 & M15 & M16 & M21 & N22 & $M$ & M10 & M11 & M12 & M13 & M14 \\
\hline 1 & 4 & 1 & 2 & 1 & 1 & 1 & 2 & 4 & 2 & 25,0 & 15,0 & 14,0 & 5,0 & 14,0 & 5,0 \\
\hline 2 & 3 & 1 & 2 & 2 & 1 & 1 & 4 & 2 & 1 & 23,0 & 26,0 & 15,0 & 4,0 & 14,0 & 4,0 \\
\hline 3 & 4 & 1 & 2 & 2 & 1 & 1 & 4 & 4 & 2 & 28,0 & 13,0 & 12,0 & 4,0 & 12,0 & 4,0 \\
\hline 4 & 3 & 3 & 3 & 3 & 1 & 2 & 3 & 4 & 1 & 17,0 & 13,0 & 11,0 & 4,1 & 11,0 & 4,0 \\
\hline 5 & 4 & 1 & 2 & 1 & 1 & 1 & 1 & 1 & 1 & 20,0 & 16,0 & 15,0 & 5,0 & 15,0 & 4,5 \\
\hline 6 & 4 & 1 & 2 & 1 & 1 & 1 & 1 & 4 & 1 & 23,0 & 19,0 & 14,0 & 5,0 & 13,0 & 4,8 \\
\hline 7 & 4 & 1 & 2 & 1 & 1 & 2 & 4 & 4 & 2 & 26,0 & 18,0 & 17,0 & 5,0 & 17,0 & 5,0 \\
\hline 8 & 4 & 1 & 3 & 3 & 1 & 2 & 1 & 2 & 1 & 27,0 & 18,0 & 17,0 & 5,0 & 15,0 & 4,0 \\
\hline 9 & 4 & 1 & 2 & 2 & 1 & 2 & 4 & 2 & 1 & 21,0 & 18,0 & 16,0 & 4,0 & 15,0 & 4,5 \\
\hline 10 & 2 & 1 & 1 & 1 & 1 & 1 & 2 & 4 & 2 & 23,0 & 19,0 & 13,0 & 4,8 & 13,4 & 4,6 \\
\hline 11 & 4 & 1 & 2 & 1 & 1 & 1 & 1 & 1 & 1 & 20,4 & 12,0 & 11,2 & 3,2 & 11,0 & 3,6 \\
\hline 12 & 4 & 1 & 3 & 3 & 1 & 2 & 2 & 2 & 2 & 20,0 & 13,0 & 12,0 & 4,0 & 12,0 & 4,0 \\
\hline 13 & 4 & 2 & 1 & 1 & 1 & 1 & 2 & 1 & 1 & 19,0 & 14,0 & 13,0 & 4,0 & 13,0 & 3,4 \\
\hline 14 & 4 & 1 & 2 & 1 & 1 & 1 & 1 & 2 & 1 & 18,0 & 14,0 & 12,0 & 4,0 & 13,0 & 4,0 \\
\hline 15 & 4 & 1 & 2 & 2 & 1 & 1 & 1 & 4 & 2 & 21,0 & 15,0 & 14,0 & 5,0 & 13,0 & 4,4 \\
\hline 16 & 4 & 1 & 2 & 1 & 1 & 1 & 1 & 4 & 2 & 28,0 & 15,0 & 17,0 & 5,0 & 16,0 & 5,5 \\
\hline$\uparrow 7$ & 4 & 1 & 2 & 4 & 1 & 1 & 1 & 4 & 1 & 30,0 & 17,0 & 16,0 & 6,0 & 15,0 & 6,0 \\
\hline 18 & 4 & 1 & 2 & 1 & 1 & 1 & 2 & 4 & 2 & 23.0 & 19,0 & 14,0 & 5,0 & 12,0 & 5,0 \\
\hline 19 & 4 & 1 & 2 & 1 & 1 & 1 & 4 & 4 & 2 & 13,0 & 14,0 & 13,0 & 4,0 & 11,0 & 3,8 \\
\hline 20 & 4 & 1 & 2 & 2 & 1 & 2 & 1 & 2 & 1 & 18,0 & 14,0 & 12,0 & 3,2 & 11,0 & 3,4 \\
\hline 21 & 4 & 1 & 2 & 1 & 1 & 2 & 2 & 1 & 1 & 21,0 & 13,9 & 12,5 & 2,0 & 13,0 & 2,0 \\
\hline 22 & 4 & 1 & 2 & 1 & 1 & 2 & 2 & 1 & 1 & 22,0 & 19,0 & 14,0 & 2,6 & 13,5 & 2,5 \\
\hline 23 & 4 & 1 & 2 & 2 & 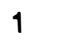 & 1 & 4 & 4 & 2 & 24,0 & 19,0 & 14,0 & 5,0 & 13,5 & 4,5 \\
\hline 24 & 4 & 1 & 2 & 2 & 1 & 1 & 4 & 4 & 2 & 28,0 & 19,0 & 14,0 & 6,0 & 14,5 & 5,5 \\
\hline 25 & 4 & 1 & 3 & 2 & 1 & 1 & 4 & 2 & 1 & 18,0 & 12,0 & 11,0 & 3,8 & 11,5 & 6,5 \\
\hline 26 & 4 & 1 & 2 & 2 & 1 & 1 & 1 & 4 & 1 & 23,0 & 16,0 & 15,0 & 5,8 & 15,0 & 5,0 \\
\hline 27 & 3 & 3 & 2 & 2 & 1 & 2 & 2 & 4 & 1 & 17,0 & 10,5 & 9,5 & 3,4 & 9,0 & 3,4 \\
\hline 28 & 4 & 1 & 1 & 1 & 1 & 1 & 2 & 4 & 1 & 18,0 & 14,0 & 13,0 & 4,0 & 12,0 & 4,0 \\
\hline 29 & 4 & 1 & 1 & 1 & 1 & 1 & 1 & 2 & 2 & 19,0 & 13,0 & 12,0 & 4,0 & 11,0 & 3,8 \\
\hline 30 & 4 & 1 & 2 & 2 & 2 & 2 & 2 & 2 & 1 & 23,0 & 17,0 & 16,0 & 3,0 & 16,0 & 3,4 \\
\hline 31 & 1 & 1 & 2 & 2 & 1 & 1 & 1 & 2 & 2 & 23,0 & 18,0 & 16,0 & 8,0 & 16,0 & 7,5 \\
\hline 32 & 4 & 1 & 2 & 2 & 1 & 2 & 2 & 1 & 1 & 17,0 & 14,0 & 13,0 & 4,0 & 11,0 & 3,6 \\
\hline 33 & 4 & 1 & 2 & 1 & 1 & 1 & 1 & 4 & 2 & 18,0 & 13,0 & 12,6 & 4,5 & 12,0 & 4,0 \\
\hline 34 & 4 & 1 & 2 & 1 & 2 & 1 & 1 & 2 & 1 & 25,0 & 27,0 & 26,0 & 2,8 & 15,5 & 2,8 \\
\hline 35 & 4 & 2 & 1 & 1 & 1 & 1 & 4 & 2 & 2 & 20,0 & 14,0 & 13,0 & 5,0 & 10,5 & 4,5 \\
\hline 36 & 4 & 2 & 2 & 1 & 2 & 1 & 2 & 2 & 1 & 32,0 & 16,0 & 14,6 & 3,6 & 14,8 & 3,6 \\
\hline 37 & 4 & 2 & 2 & 1 & 2 & 1 & 2 & 2 & 1 & 21,0 & 16,0 & 15,0 & 2,6 & 13,2 & 2,6 \\
\hline 38 & 4 & 2 & 1 & 1 & 1 & 2 & 4 & 2 & 1 & 18,0 & 16,0 & 15,0 & 4,0 & 14,0 & 4,0 \\
\hline 39 & 4 & 1 & 1 & 4 & 1 & 1 & 1 & 4 & 1 & 15,0 & 13,0 & 12,0 & 4,8 & 11,0 & 4,1 \\
\hline 40 & 4 & 4 & 1 & 1 & 1 & 1 & 1 & 2 & 1 & 19,0 & 15,0 & 14,0 & 4,5 & 13,4 & 4,0 \\
\hline 41 & 4 & 2 & 3 & 2 & 1 & 1 & 4 & 2 & 1 & 24,6 & 18,0 & 17,0 & 5,0 & 26,0 & 5,0 \\
\hline 42 & 4 & 1 & 2 & 1 & 1 & 1 & 1 & 4 & 1 & 30,0 & 15,0 & 14,0 & 4, & 14,0 & 4,5 \\
\hline 43 & 4 & 1 & 1 & 1 & 1 & 1 & 1 & 4 & 1 & 20,9 & 13,0 & 12,0 & 4,0 & 12,0 & 3,8 \\
\hline 44 & 4 & 2 & 2 & 1 & 2 & 1 & 2 & 2 & 1 & $23, \mathrm{C}$ & 16,0 & 15,0 & 2, & 14,3 & \\
\hline 45 & 4 & 1 & 2 & 1 & 1 & 1 & 2 & 4 & 1 & 18,0 & 13,5 & 12,5 & 4,4 & 13,0 & 3,5 \\
\hline 46 & 4 & 1 & 2 & 1 & 1 & 1 & 2 & 4 & 2 & 22,0 & 15 , & 14,0 & 4, & 13,0 & 4,2 \\
\hline 47 & 4 & 1 & 3 & 2 & 1 & 3 & 1 & 4 & 2 & 26, & 16 , & 15,0 & 6,0 & 14,0 & 4,4 \\
\hline 48 & 4 & 1 & 3 & 2 & 1 & 1 & 4 & 2 & 2 & 25 & 18,0 & 16,5 & 4,5 & 15,0 & 4,5 \\
\hline 49 & 4 & 1 & 2 & 1 & 2 & 2 & 1 & 2 & 1 & 16,0 & 14,2 & 13,6 & 2,0 & 12,4 & 2,0 \\
\hline 50 & 4 & 1 & 2 & 1 & 1 & 1 & 1 & 4 & 2 & 19,0 & 15,5 & 14,0 & 5,0 & 13,0 & 4,6 \\
\hline 51 & 4 & 1 & 4 & 4 & 1 & 2 & 1 & 2 & 1 & 24,0 & 14,5 & 14,0 & 4,0 & 13,0 & 3,5 \\
\hline & 4 & 1 & 2 & 1 & 1 & 1 & 1 & 4 & 2 & 22,0 & 15,0 & 14,0 & 4,5 & 13,0 & \\
\hline
\end{tabular}


Apèndice 8- Dados de morfologia originais da roça AG. M̀9 a Mí4 em cm.

\begin{tabular}{|c|c|c|c|c|c|c|c|c|c|c|c|c|c|c|c|}
\hline Árnosi & Mi & inz & ins & $\mathrm{ini4}$ & ทं์ & ivis & ivi 6 & ivi2i & ivižz & พิต & ivio & ivili & ivi 12 & ivi3 & ivit4 \\
\hline 1 & 4 & 2 & 2 & 1 & 1 & 1 & 1 & 4 & 1 & 17,0 & 15,0 & 14,0 & 5,0 & 13,2 & 4,6 \\
\hline 2 & 4 & 2 & 1 & 1 & 1 & 1 & 1 & 4 & 1 & 21,0 & 15,0 & 14,0 & 4,8 & 12,2 & 3,8 \\
\hline 3 & 4 & 2 & 1 & 1 & 1 & 1 & 1 & 4 & 1 & 18,5 & 19,8 & 14,8 & 6,2 & 13,4 & 4,5 \\
\hline 4 & 4 & 2 & 3 & 2 & 1 & 2 & 1 & 2 & $\mathbf{i}$ & 15,5 & 14,6 & 13,8 & 3,6 & 12,6 & 3,4 \\
\hline 5 & 1 & 1 & 3 & 3 & 1 & 3 & 1 & 2 & 1 & 21,0 & 16,4 & 14,8 & 5,0 & 13,8 & 4,6 \\
\hline 6 & 4 & 2 & 4 & 1 & 1 & 3 & 1 & 2 & 1 & 18,4 & 13,0 & 12,0 & 2,8 & 12,8 & 2,8 \\
\hline 7 & 4 & 2 & 3 & 2 & 1 & 3 & 1 & 2 & 1 & 22,5 & 17,0 & 16,0 & 3,6 & 14,4 & 3,8 \\
\hline 8 & 4 & 2 & 1 & 1 & 1 & 1 & 1 & 4 & 1 & 22,0 & 16,8 & 15,6 & 6,0 & 13,6 & 5,0 \\
\hline 9 & 1 & 2 & 4 & 2 & 1 & 3 & 4 & 2 & 1 & 32,0 & 19,8 & 17,6 & 4,5 & 17,0 & 4,5 \\
\hline 10 & 1 & 1 & 4 & 4 & 1 & 3 & 1 & 1 & 1 & 21,5 & 16,0 & 4,6 & 5,0 & 13,2 & 4,8 \\
\hline 11 & 2 & 2 & 4 & 4 & 1 & 3 & 1 & 1 & 1 & 27,0 & 18,8 & 17,0 & 4,8 & 16,4 & 4,8 \\
\hline 12 & 4 & 2 & 2 & 1 & $i$ & 1 & 1 & 4 & $i$ & 31,5 & 19,6 & 18,0 & 6,4 & 17,0 & 5,5 \\
\hline 13 & 2 & 2 & 4 & 2 & 1 & 3 & 1 & 1 & 1 & 22,0 & 16,0 & 15,0 & 4,4 & 14,0 & 4,2 \\
\hline 14 & 4 & 2 & 2 & 1 & 1 & 1 & 4 & 4 & 1 & 12,5 & 12,4 & 11,4 & 4,4 & 11,2 & 4,0 \\
\hline 15 & 1 & 2 & 3 & 2 & 1 & 1 & 2 & 4 & 2 & 23,5 & 18,2 & 17,0 & 5,4 & 15,0 & 4,8 \\
\hline$i 6$ & 4 & 2 & 4 & 4 & 1 & 4 & 1 & 1 & 1 & 32,0 & 19,6 & 18,4 & 6,6 & 18,6 & 6,0 \\
\hline 17 & 2 & 2 & 4 & 4 & 1 & 3 & 1 & 1 & 1 & 32,5 & 18,4 & 16,6 & 5,1 & 14,0 & 4,8 \\
\hline 18 & 4 & 2 & 4 & 4 & 1 & 3 & 1 & 1 & 1 & 25,6 & 19,2 & 17,4 & 6,6 & 16,0 & 5,0 \\
\hline 19 & 1 & 1 & 3 & 2 & 1 & 2 & 2 & 4 & 2 & 29,5 & 19,6 & 18,0 & 5,0 & 17,0 & 4,1 \\
\hline 20 & 4 & 2 & 4 & 4 & $\mathbf{i}$ & 3 & 1 & 1 & 1 & 31,0 & 21,0 & $i 9,0$ & 6,0 & 19,4 & 6,0 \\
\hline 21 & 1 & 2 & 3 & 2 & 1 & 1 & 2 & 4 & 1 & 26,0 & 18,2 & 17,0 & 4,6 & 16,6 & 4,0 \\
\hline 22 & 1 & 2 & 4 & 4 & 2 & 3 & 1 & 4 & 1 & 33,0 & 22,2 & 13,6 & 2,6 & 17,4 & 2,4 \\
\hline 23 & 4 & 2 & 4 & 4 & 1 & 3 & 1 & 1 & 1 & 28,0 & 19,8 & 17,6 & 9,0 & 17,8 & 5,0 \\
\hline 24 & 4 & 2 & 4 & 4 & 1 & 3 & $i$ & 1 & 1 & 29,8 & 20,4 & 18,4 & 5,8 & 20,0 & 5,6 \\
\hline 25 & 4 & 2 & 4 & 4 & 1 & 3 & 1 & 1 & 1 & 29,5 & 18,0 & 16,0 & 5,0 & 16,6 & 5,0 \\
\hline 26 & 4 & 2 & 4 & 4 & 1 & 3 & 1 & 1 & 1 & 32,0 & 21,0 & 19,0 & 6,0 & 18,0 & 5,0 \\
\hline 27 & 2 & 1 & 3 & 2 & 1 & 2 & 2 & 4 & 1 & 27,5 & 17,8 & 16,0 & 4,8 & 15,0 & 6,8 \\
\hline 28 & 4 & 2 & 4 & 4 & 1 & 3 & 1 & 1 & $i$ & 29,6 & i $\widehat{0,0}$ & 15,0 & 6,0 & 14,0 & 5,2 \\
\hline 29 & 4 & 2 & 4 & 4 & 1 & 3 & 1 & 1 & 1 & 25,0 & 15,4 & 13,0 & 4,4 & 13,4 & 4,0 \\
\hline 30 & 2 & 2 & 4 & 2 & 1 & 3 & 1 & 2 & 1 & 24,4 & 15,0 & 14,0 & 4,0 & 14,0 & 3,7 \\
\hline 31 & 4 & 2 & 1 & 1 & 1 & 1 & 4 & 4 & 1 & 12,0 & 13,2 & 12,4 & 4,2 & 10,2 & 4,0 \\
\hline$\sqrt{2}$ & 4 & 2 & 4 & 2 & 1 & 3 & 1 & 2 & 1 & 26,0 & 17,0 & 16,0 & 4,2 & $i 3,4$ & 4,2 \\
\hline 33 & 4 & 2 & 2 & 1 & 1 & 1 & 1 & 4 & 1 & 15,4 & 14,8 & 12,6 & 4,2 & 10,1 & 3,6 \\
\hline 34 & 4 & 2 & 4 & 2 & 1 & 3 & 1 & 2 & 1 & 24,4 & 17,4 & 16,0 & 4,4 & 15,4 & 3,6 \\
\hline 35 & 4 & 2 & 2 & 1 & 1 & 1 & 4 & 4 & 1 & 22,0 & 16,4 & 15,8 & 5,4 & 13,5 & 4,6 \\
\hline 30 & 4 & 2 & 4 & 4 & 1 & 3 & 1 & 1 & $i$ & 24,0 & 15,4 & 14,2 & 4,6 & 14,0 & 4,2 \\
\hline 37 & 4 & 2 & 4 & 4 & 1 & 3 & 1 & 1 & 1 & 27,0 & 17,2 & 16,0 & 4,2 & 15,0 & 4,2 \\
\hline 38 & 4 & 2 & 4 & 4 & 1 & 3 & 1 & 1 & 1 & 25,5 & 16,5 & 15,0 & 4,6 & 15,0 & 4,0 \\
\hline 39 & 4 & 2 & 4 & 4 & 1 & 3 & 1 & 1 & 1 & 26,0 & 16,6 & 15,0 & 4,4 & 14,6 & 4,2 \\
\hline 40 & 4 & 2 & 4 & 4 & 1 & 3 & 1 & $i$ & 1 & 21,0 & $i 4,6$ & 13,6 & 3,6 & $i 2,0$ & 3,3 \\
\hline 41 & 4 & 2 & 4 & 4 & 1 & 3 & 1 & 1 & 1 & 20,0 & 14,0 & 13,2 & 3,2 & 12,4 & 3,4 \\
\hline 42 & 4 & 2 & 2 & 1 & 1 & 1 & 4 & 4 & 1 & 12,8 & 11,6 & 10,8 & 4,8 & 9,2 & 3,8 \\
\hline 43 & 4 & 2 & 2 & 1 & 1 & 1 & 4 & 4 & 1 & 11,2 & 12,4 & 11,6 & 4,0 & 9,0 & 3,6 \\
\hline 44 & 4 & 2 & 4 & 4 & 1 & 3 & 1 & 1 & 1 & 27,0 & 18,8 & 17,6 & 4,2 & 16,60 & 4,0 \\
\hline 45 & 4 & 2 & 4 & 4 & 1 & 3 & 1 & 1 & 1 & 21,4 & 16,8 & 15,6 & 4,3 & 15,2 & 4,0 \\
\hline 46 & 4 & 2 & 4 & 4 & 1 & 3 & 1 & 1 & 1 & 22,0 & 15,4 & 14,0 & 5,4 & 13,0 & 4,6 \\
\hline 47 & 4 & 2 & 4 & 4 & 1 & 3 & 1 & 1 & 1 & 25,0 & 22,9 & 16,6 & 5,8 & 14,2 & 4,7 \\
\hline 48 & 4 & 2 & 4 & 4 & $i$ & 3 & $i$ & 1 & 1 & 23,0 & 15,2 & 14,2 & 4,0 & 13,3 & 4,2 \\
\hline 49 & 4 & 2 & 4 & 4 & 1 & 3 & 1 & 1 & 1 & 22,0 & 17,4 & 16,0 & 4,2 & 15,4 & 4,0 \\
\hline 50 & 4 & 2 & 4 & 4 & 1 & 3 & 1 & 1 & 1 & 22,0 & 14,2 & 12,0 & 5,4 & 11,8 & 4,6 \\
\hline
\end{tabular}


Apêndice 9- Dados de mortologia originais da roça DFP. M̀Y a Mi14 em cm.

\begin{tabular}{|c|c|c|c|c|c|c|c|c|c|c|c|c|c|c|c|}
\hline Amost & M1 & N2 & MO & M4 & M6 & M15 & M16 & M21 & $M 22$ & $M$ & M10 & M11 & M12 & M13 & M14 \\
\hline 1 & 4 & 2 & 2 & 2 & 1 & 2 & 2 & 2 & 1 & 21,0 & 18,0 & 17,0 & 2,0 & 17,0 & 2,0 \\
\hline 2 & 4 & 2 & 2 & 2 & 1 & 3 & 4 & 2 & 1 & 23,5 & 18,0 & 17,0 & 4,2 & 16,0 & 4,0 \\
\hline 3 & 4 & 2 & 2 & 2 & 2 & 3 & 4 & 2 & $i$ & $i 8,0$ & 14,5 & 13,4 & 4,4 & 13,0 & 4,0 \\
\hline 4 & 4 & 2 & 3 & 2 & $\overline{1}$ & 1 & 4 & 1 & 1 & 19,0 & 15,0 & 14,0 & 4,5 & 13,0 & 4,0 \\
\hline 5 & 4 & 2 & 3 & 2 & 1 & 3 & 4 & 2 & 1 & 19,0 & 14,4 & 14,0 & 4,0 & 12,0 & 3,5 \\
\hline 6 & 4 & 2 & 2 & 1 & 2 & 2 & 2 & 1 & 1 & 20,0 & 17,0 & 16,0 & 3,0 & 15,5 & 3,0 \\
\hline 7 & 4 & 2 & 3 & 2 & $i$ & 2 & $i$ & 2 & $i$ & 20,0 & 15,0 & $j 4,0$ & 4,0 & 14,0 & 4,0 \\
\hline 8 & 4 & 2 & 2 & 1 & 1 & 3 & 4 & 2 & 2 & 18,0 & 17,0 & 15,6 & 4,2 & 14,5 & 4,0 \\
\hline 9 & 4 & 2 & 2 & 1 & 1 & 3 & 4 & 2 & 1 & 18,0 & 16,5 & 15,2 & 4,5 & 14,4 & 3,8 \\
\hline 10 & 4 & 2 & 2 & 1 & 1 & 1 & 1 & 2 & 2 & 20,0 & 15,0 & 13,6 & 3,8 & 13,6 & 3,6 \\
\hline 11 & 4 & 2 & 2 & 1 & 1 & $i$ & $\mathbf{i}$ & 2 & $i$ & 19,0 & $i 6,0$ & 15,0 & 4,5 & 14,5 & 4,5 \\
\hline 12 & 4 & 2 & 2 & 1 & 1 & 1 & 1 & 4 & 2 & 20,9 & 15,4 & 14,0 & 4,8 & 13,0 & 4,2 \\
\hline 13 & 4 & 2 & 2 & 2 & 1 & 3 & 4 & 2 & 2 & 20,0 & 15,6 & 14,0 & 5,0 & 13,4 & 4,4 \\
\hline 14 & 4 & 2 & 2 & 1 & $q$ & 2 & 1 & 2 & 1 & 17,0 & 13,0 & 12,0 & 4,0 & 11,5 & 3,6 \\
\hline$i 5$ & 4 & 2 & 2 & 2 & $i$ & 2 & 2 & 2 & 1 & $i 7,6$ & $i 2,0$ & 11,0 & 4,4 & $i 2,0$ & 4,4 \\
\hline 16 & 4 & 2 & 2 & 2 & 2 & 2 & 2 & 2 & 1 & 20,0 & 15,8 & 14,4 & 2,2 & 14,0 & 2,8 \\
\hline 17 & 4 & 2 & 2 & 1 & 1 & 1 & 1 & 2 & 1 & 17,6 & 14,0 & 13,4 & 4,0 & 11,6 & 3,4 \\
\hline 18 & 4 & 2 & 2 & 1 & 1 & 3 & 4 & 2 & 1 & 20,0 & 17,0 & 16,0 & 4,0 & 16,5 & 4,0 \\
\hline 19 & $i$ & 2 & $i$ & $i$ & $\mathbf{i}$ & $\mathrm{i}$ & 2 & 4 & 2 & 23,0 & 18,0 & 17,0 & 5,8 & 14,0 & 5,4 \\
\hline 20 & 4 & 2 & 2 & 1 & 1 & 2 & 1 & 2 & 2 & 16,0 & 11,8 & 11,0 & 6,6 & 10,0 & 6,6 \\
\hline 21 & 4 & 1 & 2 & 2 & 1 & 1 & 1 & 4 & 2 & 22,0 & 15,6 & 14,0 & 4,8 & 12,2 & 4,0 \\
\hline 22 & 4 & 2 & 1 & 1 & 1 & 1 & 1 & 2 & 1 & 25,0 & 16,0 & 15,0 & 5,5 & 13,6 & 5,0 \\
\hline 23 & 4 & 2 & 2 & 2 & $i$ & 3 & 4 & 2 & 2 & 15,0 & 15,0 & $\{3,6$ & 3,8 & $i 2,0$ & 3,2 \\
\hline 24 & 4 & 2 & 2 & 2 & 2 & 1 & 2 & 2 & 1 & 17,0 & 16,0 & 15,0 & 5,8 & 13,0 & 2,0 \\
\hline 25 & 4 & 2 & 2 & 2 & 2 & 1 & 2 & 2 & 1 & 22,0 & 16,5 & 16,0 & 2,0 & 15,0 & 2,4 \\
\hline 26 & 4 & 2 & 3 & 3 & 1 & 5 & 1 & 2 & 2 & 21,0 & 15,0 & 14,0 & 3,8 & 12,6 & 3,2 \\
\hline $2 T$ & 4 & 2 & 2 & 2 & 1 & $i$ & $\mathbf{i}$ & 4 & $i$ & 24,0 & 16,0 & 14,4 & 5,5 & 13,4 & 5,5 \\
\hline 28 & 4 & 2 & 2 & 2 & 1 & 3 & 4 & 2 & 1 & 12,0 & 12,0 & 11,4 & 3,6 & 10,0 & 3,2 \\
\hline 29 & 4 & 2 & 2 & 2 & 1 & 3 & 4 & 2 & 1 & 20,2 & 16,0 & 14,8 & 4,0 & 14,0 & 3,6 \\
\hline 30 & 4 & 2 & 1 & 1 & 1 & 1 & 1 & 4 & 2 & 23,0 & 15,6 & 14,6 & 5,2 & 13,6 & 5,2 \\
\hline
\end{tabular}


Apêndice 10- Dados de morfologia originais da roça FA. M9 a M14 em cm.

\begin{tabular}{|c|c|c|c|c|c|c|c|c|c|c|c|c|c|c|c|}
\hline Amast & MH & 12 & MB & MA & M6 & M15 & M16 & M21 & NO2 & MO & M10 & M11 & M12 & M13 & M14 \\
\hline 1 & 4 & 2 & 2 & 1 & 1 & 2 & 1 & 2 & 1 & 25,0 & 17,0 & 16,0 & 4,8 & 14,8 & 4,0 \\
\hline 2 & 4 & 2 & 2 & 1 & 1 & 2 & 1 & 1 & 1 & 21,0 & 18,0 & 17,0 & 4,5 & 14,5 & 4,2 \\
\hline 3 & 1 & 1 & 3 & 2 & 1 & 1 & 2 & 1 & 1 & 21,0 & 15,6 & 14,4 & 3,0 & 12,4 & 2,4 \\
\hline 4 & 4 & 2 & 2 & 1 & 1 & 2 & 1 & 1 & 1 & 24,0 & 17,0 & 16,4 & 4,2 & 15,0 & 4,0 \\
\hline 5 & 4 & 2 & 2 & 1 & 1 & 2 & 1 & 1 & 1 & 20,0 & 15,5 & 14,0 & 4,5 & 13,0 & 4,2 \\
\hline 6 & 4 & 2 & 2 & 1 & 1 & 2 & 1 & 1 & 1 & 23,0 & 16,6 & 15,0 & 4,2 & 14,0 & 4,0 \\
\hline 7 & 4 & 2 & 2 & 1 & 1 & 2 & 1 & 1 & 1 & 25,0 & 16,0 & 14,6 & 4,0 & 13,0 & 4,2 \\
\hline 8 & 4 & 1 & 3 & 2 & 1 & 2 & 2 & 1 & 1 & 17,0 & 11,2 & 10,2 & 3,2 & 9,2 & 3,0 \\
\hline 9 & 4 & 2 & 2 & 1 & 1 & 2 & 1 & 1 & 1 & 19,0 & 13,0 & 12,0 & 3,8 & 11,0 & 3,8 \\
\hline 10 & 4 & 2 & 2 & 1 & 1 & 2 & 1 & 4 & 1 & 23,0 & 16,2 & 15,0 & 4,4 & 13,0 & 4,0 \\
\hline 11 & 4 & 2 & 2 & 1 & 1 & 2 & 1 & 1 & 1 & 25,0 & 18,0 & 17,0 & 4,8 & 15,0 & 4,5 \\
\hline 12 & 4 & 2 & 2 & 1 & 1 & 2 & 1 & 4 & 1 & 26,0 & 16,4 & 15,0 & 5,2 & 14,0 & 4,2 \\
\hline 13 & 4 & 2 & 2 & 1 & 1 & 2 & 1 & 1 & 1 & 28,5 & 17,0 & 15,6 & 5,0 & 14,0 & 4,2 \\
\hline 14 & 4 & 2 & 2 & 1 & 1 & 2 & 1 & 1 & 1 & 27,0 & 16,0 & 15,0 & 4,4 & 14,0 & 4,0 \\
\hline 15 & 1 & 1 & 3 & 2 & 1 & 1 & 2 & 1 & 1 & 24,0 & 18,0 & 16,0 & 3,2 & 16,0 & 3,8 \\
\hline 16 & 4 & 2 & 2 & 1 & 1 & 2 & 1 & 1 & 1 & 23,6 & 36,0 & 24,4 & 4,4 & 13,0 & 4,0 \\
\hline 17 & 4 & 2 & 2 & 1 & 1 & 2 & 1 & 1 & 1 & 23,0 & 15,6 & 14,0 & 4,8 & 14,0 & 4,6 \\
\hline 18 & 4 & 1 & 2 & 1 & 2 & 2 & 2 & 1 & 1 & 19,0 & 15,0 & 13,8 & 1,8 & 13,0 & 1,8 \\
\hline 19 & 4 & 2 & 2 & 1 & 1 & 2 & 1 & 1 & 1 & 25,0 & 17,0 & 16,0 & 5,0 & 14,6 & 4,4 \\
\hline 20 & 4 & 2 & 2 & 1 & 1 & 2 & 1 & 1 & 1 & 23,0 & 15,0 & 14,0 & 4,8 & 13,0 & 3,8 \\
\hline 21 & 4 & 2 & 2 & 1 & 1 & 2 & 1 & 1 & 1 & 26,0 & 17,0 & 15,5 & 5,2 & 13,8 & 4,4 \\
\hline 22 & 4 & 1 & 3 & 2 & 1 & 2 & 2 & & & 18,0 & 12,8 & 12.0 & 4,0 & 10,6 & 3,6 \\
\hline 23 & 4 & 2 & 2 & 1 & 1 & 2 & 1 & & & 18,6 & 13,0 & 12,0 & 4,2 & 11,2 & 4,0 \\
\hline 24 & 4 & 1 & 3 & 2 & 1 & 2 & 2 & & & 14,0 & 11,0 & 10,4 & 3,2 & 9,6 & 2,2 \\
\hline 25 & 4 & 2 & 2 & 1 & 1 & 2 & 1 & & & 27,0 & 18,0 & 16,6 & 4,4 & 15,0 & 4,5 \\
\hline 26 & 1 & 1 & 3 & 3 & 1 & 5 & 1 & & & 26,0 & 17,0 & 16,0 & 5,0 & 14,4 & 4,4 \\
\hline 27 & 4 & 2 & 2 & 1 & 1 & 2 & 1 & & & 25,0 & 16,6 & 15,4 & 4,8 & 15,0 & 4,4 \\
\hline 28 & 4 & 2 & 2 & 1 & 1 & 2 & 1 & & & 31,0 & 20,0 & 18,2 & 5,4 & 18,0 & 5,2 \\
\hline 29 & 4 & 1 & 3 & 2 & 1 & 2 & 5 & & & 26,0 & 18,8 & 17,5 & 5,0 & 16,0 & 4,4 \\
\hline 30 & 4 & 2 & 2 & 1 & 1 & 2 & 1 & & & 24,4 & 17,0 & 15,6 & 4,8 & 13,2 & 4,0 \\
\hline 31 & 4 & 1 & 3 & 2 & 1 & 1 & 2 & & & 26,0 & 19,6 & 18,0 & 3,8 & 16,8 & 4,8 \\
\hline 32 & 4 & 2 & 2 & 1 & 1 & 2 & 1 & & & 26,0 & 16,0 & 14,5 & 4,8 & 13,4 & 4,0 \\
\hline 33 & 4 & 2 & 2 & 1 & 1 & 2 & 1 & & & 17,0 & 12,2 & 11,0 & 3, & 10,0 & 3,0 \\
\hline 34 & 4 & 2 & 2 & 1 & 1 & 2 & 1 & & & 17,0 & 13,0 & 12,4 & 3,4 & 11,0 & 3,0 \\
\hline 35 & 4 & 2 & 2 & 1 & 1 & 2 & 1 & & & 20,0 & 14,0 & 13,0 & 4,0 & 12,0 & 3,8 \\
\hline 36 & 4 & 2 & 2 & 1 & 1 & 2 & 1 & & & 21,5 & 16,0 & 15,0 & 4,4 & 13,0 & 3,8 \\
\hline 37 & 4 & 2 & 2 & 1 & 1 & 2 & 1 & & & 14,0 & 13,0 & 12,0 & 6,8 & 12,0 & 3,4 \\
\hline 38 & 4 & 1 & 2 & 2 & 1 & 1 & 2 & & & 20,4 & 14,0 & 13,0 & 2,4 & 11,5 & 3,0 \\
\hline 39 & 4 & 2 & 2 & 1 & 1 & 2 & 1 & & & 24,0 & 18,0 & 16 & 5, & 15,0 & 4,6 \\
\hline 40 & 4 & 2 & 2 & 1 & 1 & 2 & 1 & & & 24,0 & 7,0 & 15,4 & 4,8 & 13,8 & re \\
\hline
\end{tabular}


Apêndice 11- Dados de morfologia originais da roça FO. M99 a Mi14 em cm.

\begin{tabular}{|c|c|c|c|c|c|c|c|c|c|c|c|c|c|c|c|}
\hline Amest & $M$ & Ne & $\mathbf{M B}$ & $\mathbf{M 4}$ & Mo & M15 & M16 & M21 & $\mathrm{N} 22$ & MO & M10 & M11 & M12 & $\begin{array}{l}\text { M13 } \\
132\end{array}$ & M14 \\
\hline 1 & $\begin{array}{l}4 \\
4\end{array}$ & 2 & 2 & 1 & 1 & 3 & 1 & 1 & 1 & 25,0 & 17,0 & 15,0 & 4,0 & 13,2 & 4,2 \\
\hline 2 & $\begin{array}{l}4 \\
4\end{array}$ & 2 & 2 & 1 & 1 & 3 & 1 & 1 & 1 & 25,0 & 18,0 & 16,2 & 5,0 & 14,6 & 4,2 \\
\hline 3 & 4 & 2 & 2 & 1 & 1 & 3 & 1 & 1 & 1 & 28,5 & 19,8 & 18,0 & 5,0 & 16,5 & 5,0 \\
\hline 4 & 4 & 2 & 4 & 4 & 1 & 4 & 1 & 1 & 1 & 19,0 & 19,0 & 17,5 & 5,0 & 16,6 & 4,8 \\
\hline 5 & 4 & 2 & 2 & 1 & 1 & 3 & 1 & 1 & 1 & 22,0 & 15,7 & 14,5 & 4,6 & 13,0 & 3,8 \\
\hline 6 & 4 & 2 & 2 & 1 & 1 & 3 & 1 & 1 & 1 & 23,0 & 16,0 & 15,0 & 4,5 & 13,5 & 4,0 \\
\hline 7 & 4 & 2 & 4 & 4 & 1 & 3 & 1 & 1 & 1 & 26,0 & 17,0 & 16,0 & 5,0 & 15,0 & 3,5 \\
\hline 8 & 4 & 2 & 2 & 1 & 1 & 3 & 1 & 1 & 1 & 24,0 & 17,0 & 16,0 & 4,6 & 14,0 & 4,0 \\
\hline 9 & 4 & 2 & 2 & 1 & 1 & 3 & 1 & 1 & 1 & 25,0 & 15,0 & 14,8 & 4,2 & 13,0 & 3,6 \\
\hline 10 & 4 & 2 & 2 & 1 & 1 & 3 & 1 & 1 & 1 & 24,0 & 16,4 & 15,0 & 4,0 & 13,2 & 4,0 \\
\hline 11 & 4 & 2 & 2 & 1 & 1 & 3 & 1 & 1 & 1 & 22,6 & 16,0 & 15,0 & 4,2 & 13,2 & 5,8 \\
\hline 12 & 4 & 2 & 2 & 1 & 1 & 3 & 1 & 1 & 1 & 24,9 & 17,0 & 16,0 & 4,4 & 15,5 & 4,6 \\
\hline 13 & 4 & 1 & 3 & 3 & 1 & 2 & 2 & 1 & 1 & 18,6 & 12,2 & 11,2 & 3,6 & 10,4 & 3,6 \\
\hline$\uparrow 4$ & 4 & 2 & 4 & 4 & 3 & 3 & 4 & 1 & 1 & 29,0 & 15,0 & 14,0 & 2,2 & 13,2 & 2,2 \\
\hline 15 & 4 & 2 & 2 & 1 & 1 & 3 & 1 & 1 & 1 & 17,0 & 12,4 & 12,3 & 3,8 & 10,2 & 3,2 \\
\hline 16 & 4 & 2 & 2 & 1 & 1 & 3 & 1 & 4 & 1 & 18,0 & 13,0 & 12,8 & 3,6 & 11,0 & 3,5 \\
\hline 17 & 4 & 2 & 2 & 1 & 1 & 3 & 1 & 1 & 1 & 22,0 & 16,4 & 15,0 & 4,2 & 14,0 & 4,2 \\
\hline 18 & 4 & 2 & 2 & 1 & 1 & 3 & 1 & 1 & 1 & 29,0 & 18.0 & 16,2 & 5,5 & 15,0 & 4,6 \\
\hline 19 & 4 & 2 & 2 & 1 & 1 & 3 & 1 & 1 & 1 & 29,0 & 17,0 & 15,4 & 5,0 & 14,0 & 4,2 \\
\hline 20 & 4 & 2 & 2 & 1 & 1 & 3 & 1 & 1 & 1 & 23,0 & 16,5 & 15,0 & 5,0 & 16,2 & 4,2 \\
\hline 21 & 4 & 2 & 2 & 1 & 1 & 3 & 1 & & & 25,0 & 18,8 & 17,0 & 5,6 & 16,0 & 5,2 \\
\hline 22 & 4 & 2 & 2 & 1 & 1 & 3 & 1 & & & 21,8 & 14,5 & 13,5 & 4,0 & 13,0 & 4,0 \\
\hline 23 & 4 & 2 & 2 & 1 & 1 & 3 & 1 & & & 21,0 & 12,0 & 13,0 & 3,6 & 12,8 & 3,5 \\
\hline 24 & 4 & 2 & 2 & 1 & 1 & 3 & 1 & & & 31,0 & 18,8 & 16,8 & 5,2 & 15,4 & 4,2 \\
\hline 25 & 4 & 2 & 2 & 1 & 1 & 3 & 1 & & & 26,9 & 16,4 & 15,0 & 5,0 & 14,0 & 4,5 \\
\hline 26 & 4 & 2 & 3 & 3 & 1 & 2 & 2 & & & 20,0 & 14,0 & 12,4 & 4,4 & 11,0 & 4,0 \\
\hline 27 & 4 & 2 & 2 & 1 & 1 & 3 & 1 & & & 22,0 & 17,4 & 16,0 & 6,2 & 14,0 & 5,0 \\
\hline 28 & 4 & 2 & 2 & 1 & 1 & 3 & 1 & & & 21,0 & 15,2 & 14,0 & 4,4 & 14,0 & 4,4 \\
\hline 29 & 4 & 2 & 2 & 1 & 1 & 3 & 1 & & & 25,0 & 17,0 & 16,0 & 5,0 & 13,2 & 4,2 \\
\hline 30 & 4 & 2 & 2 & 1 & 1 & 3 & 1 & & & 28,0 & 18,0 & 17,0 & 5,0 & 15,6 & 4,5 \\
\hline 31 & 4 & 2 & 2 & 1 & 1 & 3 & 1 & & & 25,0 & 18,0 & 16,0 & 4,8 & 15,0 & 4,2 \\
\hline 32 & 4 & 2 & 4 & 2 & 1 & 3 & 4 & & & 25,0 & 17,0 & 15,0 & 5,0 & 14,5 & 5,0 \\
\hline 33 & 4 & 2 & 2 & 1 & 1 & 3 & 1 & & & 25,0 & 18,6 & 17,0 & 4,8 & 16,0 & 4,8 \\
\hline 34 & 4 & 2 & 3 & 3 & 1 & 2 & 2 & & & 22,0 & 16,4 & 14,8 & 4,0 & 13,6 & 4,0 \\
\hline 35 & 4 & 2 & 2 & 1 & 1 & 3 & 1 & & & 24,0 & 17,0 & 15,5 & 5,0 & 14,0 & 4,2 \\
\hline 36 & 4 & 2 & 2 & 1 & 1 & 3 & 1 & & & 22,0 & 17,0 & 15,6 & 4,5 & 15,0 & 4,4 \\
\hline 37 & 4 & 2 & 2 & 1 & 1 & 3 & 1 & & & 23,5 & 17,4 & 15,6 & 4,6 & 14,6 & 4,5 \\
\hline 38 & 4 & 2 & 2 & 1 & 1 & 3 & 1 & & & 21,0 & 15,0 & 14,0 & 4,2 & 12,0 & 3,2 \\
\hline 39 & 4 & 2 & 2 & 1 & 1 & 3 & 1 & & & 18,0 & 14,0 & 13,0 & 4,0 & 11,4 & 3,2 \\
\hline 40 & 4 & 2 & 2 & 1 & 1 & 3 & 1 & & & 18,0 & 16,0 & 14,0 & 3,8 & 13,4 & 3,0 \\
\hline 41 & 4 & 2 & 4 & 4 & 1 & 4 & 1 & & & 26,0 & 14,5 & 13,8 & 4,4 & 12,4 & 3,2 \\
\hline
\end{tabular}


Apêndice 12- Marriz de similaridades hierarquizadas.

$\begin{array}{cccccc} & \text { DFG } & \text { DFP } & \text { AG } & \text { FA } & \text { FO } \\ \text { DFG } & 0,6829 & & & & \\ \text { DFP } & 0,6516 & 0,7596 & & & \\ \text { AG } & 0,6465 & 0,6579 & 0,6974 & & \\ \text { FA } & 0,7193 & 0,6564 & 0,7053 & 0,8864 & \\ \text { FO } & 0,7071 & 0,6384 & 0,6779 & 0,8531 & 0,8841\end{array}$

Apêndice 13- Matriz de distâncias hierarquizadas.

$\begin{array}{cccccc} & \text { DFG } & \text { DFP } & \text { AG } & \text { FA } & \text { FO } \\ \text { DFG } & 0,3171 & & & & \\ \text { DFP } & 0,3484 & 0,2404 & & & \\ \text { AG } & 0,3535 & 0,3421 & 0,3026 & & \\ \text { FA } & 0,2807 & 0,3436 & 0,2947 & 0,1136 & \\ \text { FO } & 0,2929 & 0,3616 & 0,3221 & 0,1469 & 0,1159\end{array}$

Apêndice 14- Matriz de distâncias hierarquizadas corrigida.

$\begin{array}{lllll} & \text { DFG } & \text { DFP } & \text { AG } & \text { FA } \\ \text { DFP } & 1,25 & & & \\ \text { AG } & 1,14 & 1,26 & & \\ \text { FA } & 1,30 & 1,94 & 1,42 & \\ \text { FO } & 1,35 & 2,02 & 1,54 & 1,28\end{array}$


Apêndice 15- Gel revelado com o sistema $\mathrm{MDH}$

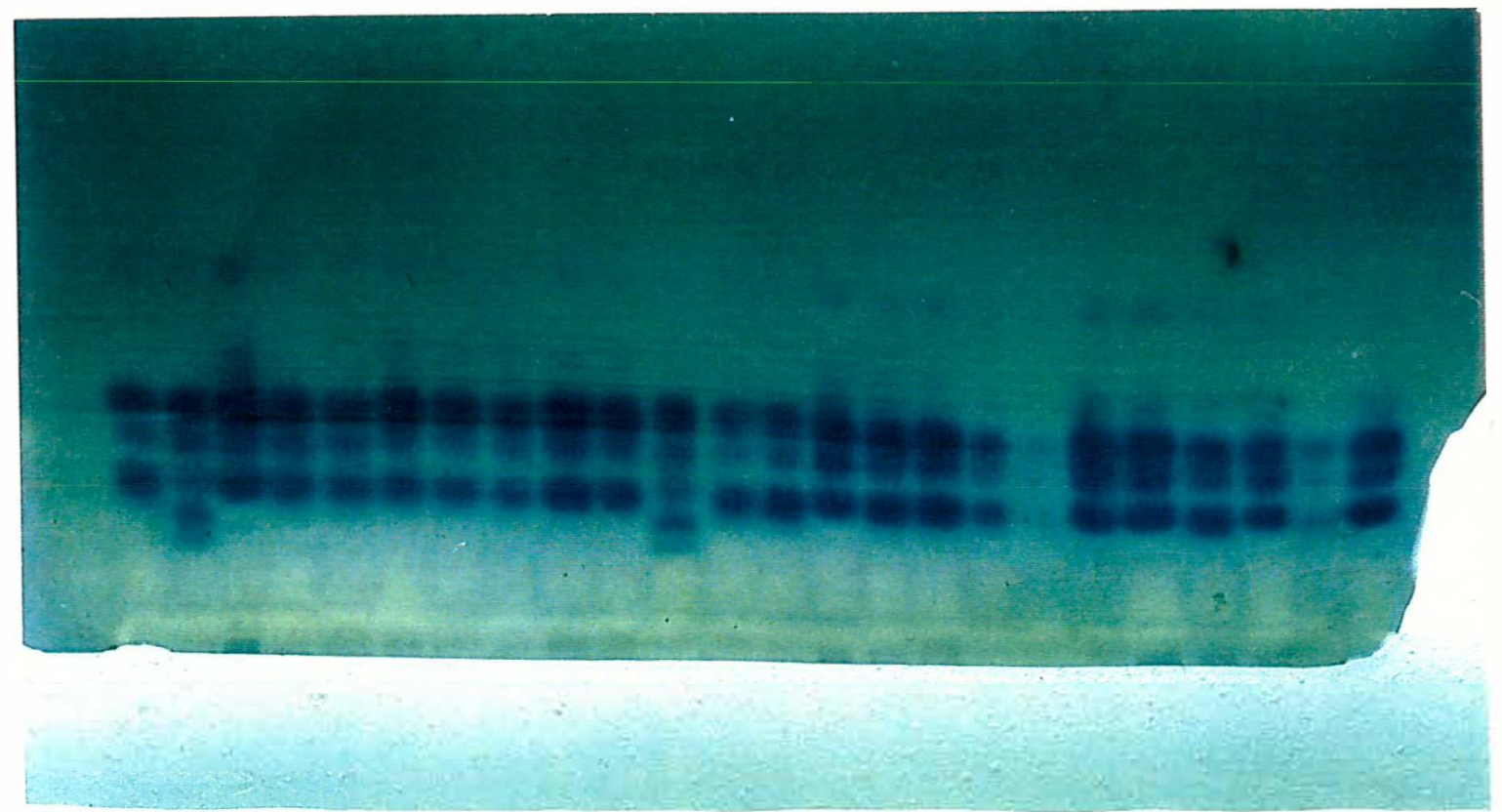

Apêndice 16- Gel revelado com o sistema SKDH.

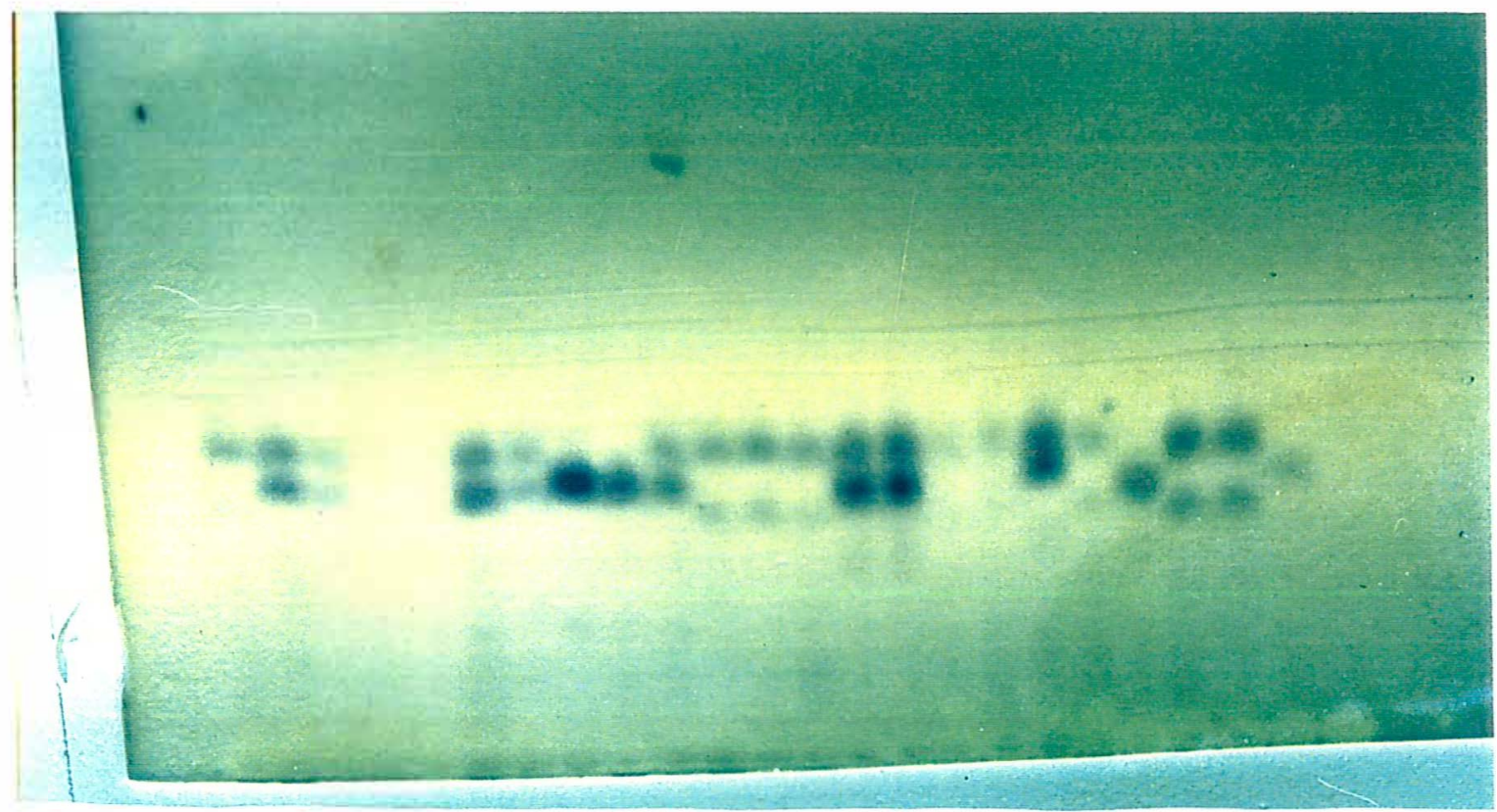


Apêndice 17- Gel revelado com o sistema LAP.

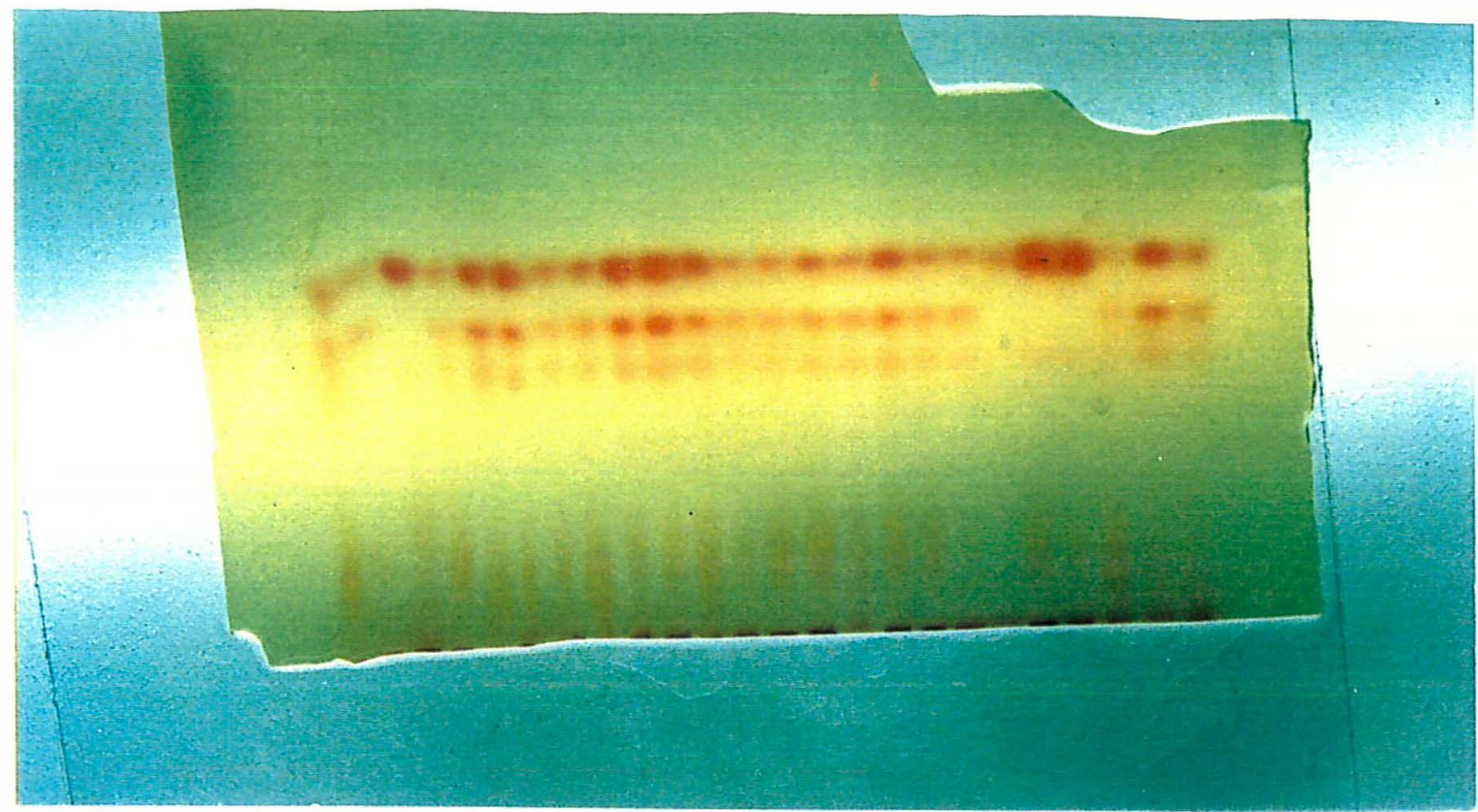

Apêndice 18- Roça de mandioca e uma roça abandonada ao fundo já em fase adiantada de regeneração.

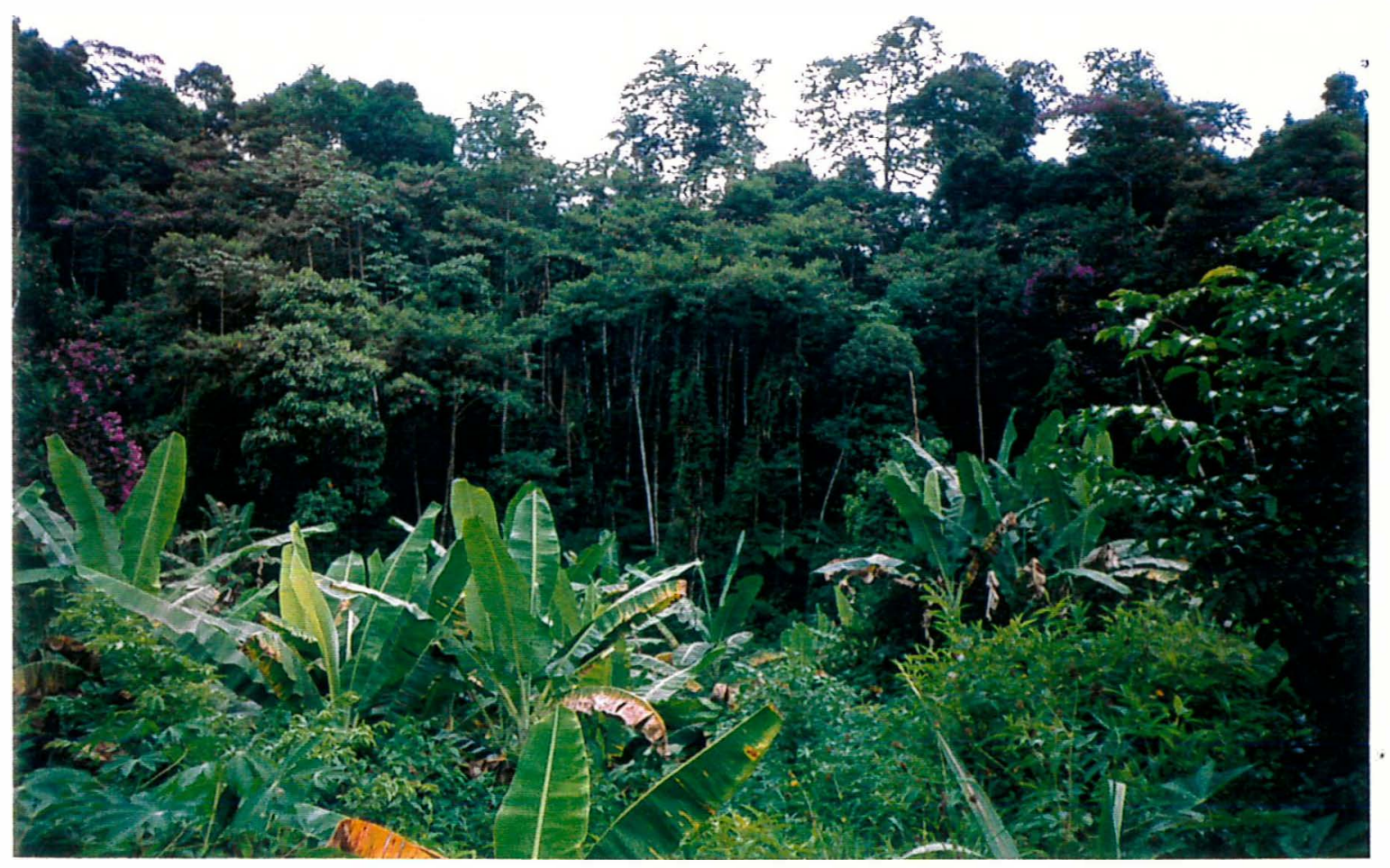

